\title{
WestVirginiaUniversity
}

THE RESEARCH REPOSITORY @ WVU

Graduate Theses, Dissertations, and Problem Reports

2020

\section{Procedure for Asphalt Mixture Friction Evaluation for WVDOH}

Danielle Marie Hoyer

West Virginia University, dmhoyer@mix.wvu.edu

Follow this and additional works at: https://researchrepository.wvu.edu/etd

Part of the Civil Engineering Commons, and the Transportation Engineering Commons

\section{Recommended Citation}

Hoyer, Danielle Marie, "Procedure for Asphalt Mixture Friction Evaluation for WVDOH" (2020). Graduate Theses, Dissertations, and Problem Reports. 7574.

https://researchrepository.wvu.edu/etd/7574

This Thesis is protected by copyright and/or related rights. It has been brought to you by the The Research Repository @ WVU with permission from the rights-holder(s). You are free to use this Thesis in any way that is permitted by the copyright and related rights legislation that applies to your use. For other uses you must obtain permission from the rights-holder(s) directly, unless additional rights are indicated by a Creative Commons license in the record and/ or on the work itself. This Thesis has been accepted for inclusion in WVU Graduate Theses, Dissertations, and Problem Reports collection by an authorized administrator of The Research Repository @ WVU. For more information, please contact researchrepository@mail.wvu.edu. 
Procedure for Asphalt Mixture Friction Evaluation for WVDOH

Danielle Hoyer

Thesis submitted

to the Benjamin M. Statler College of Engineering and Mineral Resources at West Virginia University

in partial fulfillment of the requirements for the degree of

Master of Science in

Civil and Environmental Engineering

John. P. Zaniewski, Ph. D., P.E., Chair

Yoojung Yoon, Ph. D.

Fei Dai, Ph. D.

Department of Civil Engineering

Morgantown, West Virginia

2020

Keywords: Asphalt, Polishing, BPT, Friction, Skid Resistance

Copyright 2020 Danielle Hoyer 


\section{ABSTRACT \\ Procedure for Asphalt Mixture Friction Evaluation for WVDOH}

Danielle Hoyer

Monitoring asphalt skid resistance in the laboratory could aid in improved friction prediction capabilities and provide insight for developing alternative asphalt mixture designs in the future. The West Virginia Department of Highways (WVDOH) sought the design of a laboratory accelerated asphalt polishing machine to further expand on current skid resistance measurement practices. The design is modeled after the North Carolina State University (NCSU) polishing machine detailed in ASTM E660. The purpose of this research was to develop a testing procedure for the polishing equipment. Friction was monitored with the British Pendulum Tester (BPT) according to ASTM E303.

Specimens were prepared using a Superpave Gyratory Compactor (SGC) at two air void contents (4\% and 8\%) using four asphalt surface course mixtures (JFA 12.5mm Skid-RAP, WVP W1-RAP, Greer W1, WVP 12.5mm Skid-RAP). Specimens were placed in the polishing machine for a minimum of 48,000 wheel passes and conditioned with silicon carbide abrasive powder for accelerated polishing. Tire toe angles were adjusted between low $\left(4^{\circ}\right.$ toed in and $2^{\circ}$ toed out) and high $\left(8^{\circ}\right.$ toed in and $4^{\circ}$ toed out) toe angles. Average BPN values were plotted and used for slope calculations to investigate asymptotic behavior. These trend lines were also used as prediction models to determine the number of wheel passes required to reach minimum BPN limits; a larger number of wheel passes indicates more polish resistance. Variables evaluated: specimen air void content (VTM), tire toe angles, tire type, nominal maximum aggregate size (NMAS), and asphalt production company were considered for analysis. Data were compared using t-tests at $95 \%$ confidence to determine statistical differences between average BPN measurements. The most polish resistant mixture was the WVP W1-RAP mix; JFA 12.5mm Skid-RAP was the least. T-tests concluded only statistically different results for toe angles and lab/field comparisons. Lower friction values for higher toe angles suggest increased polishing when using higher toe. These results could provide insight on polishing procedure optimization and skid resistant characteristics of asphalt mixtures. 


\section{ACKNOWLEDGEMENTS}

I would like to take this opportunity to extend my gratitude to those who have helped me in achieving this goal. First, I would like to thank my advisor, Dr. Zaniewski, for not only presenting me with this opportunity, but also for providing me with the tools and guidance needed to complete this degree. I also want to thank Dr. Yoojung Yoon and Dr. Fei Dai for being a part of my committee and supporting this journey.

Additionally, I want to thank the WVDOH for this project opportunity as well as the resources and equipment necessary to complete it. I would like to thank participating contractors for also providing resources throughout the course of my experiment. I am also extremely grateful to my fellow peers for their time and effort in assisting and supporting me with this project. And lastly, I would like to take a moment to sincerely thank my family and friends. I truly could not have done this without their endless love and support. 


\section{Table of Contents}

List of Figures ................................................................................................................... vii

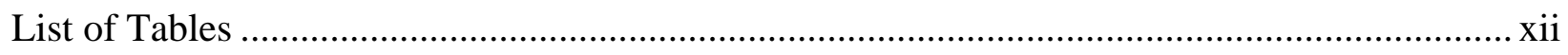

List of Abbreviations ..........................................................................................................

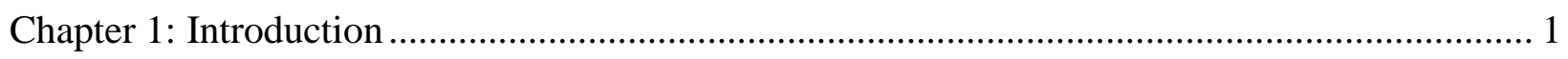

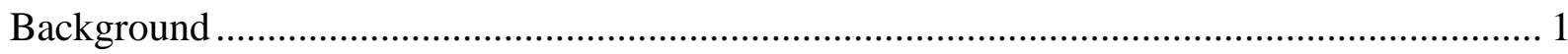

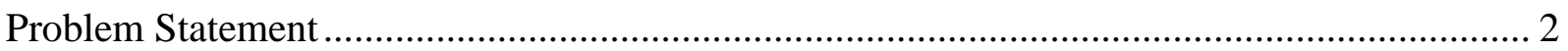

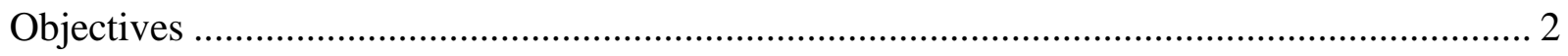

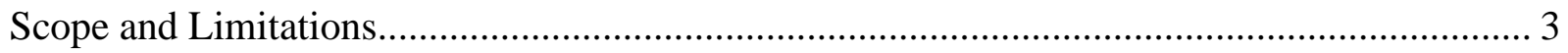

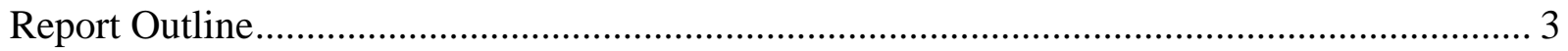

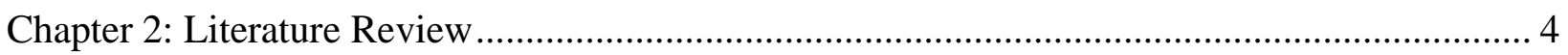

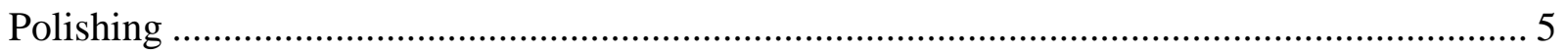

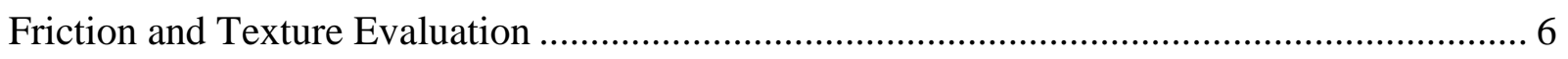

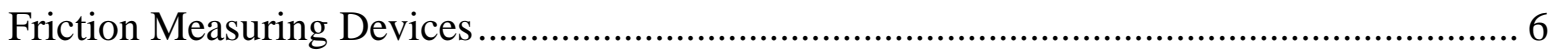

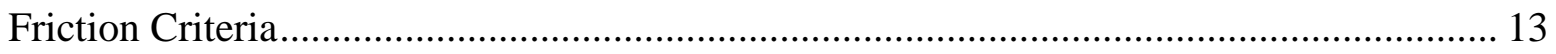

Asphalt Mixture Friction Characteristics.......................................................................... 15

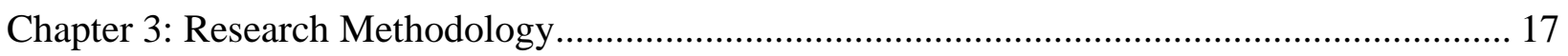

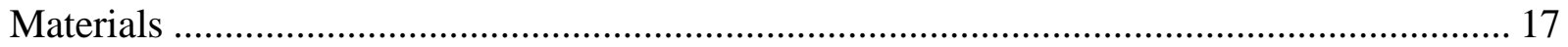

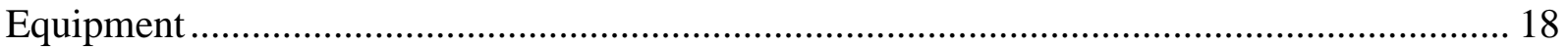

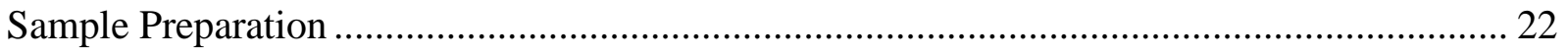

Development of Accelerated Polishing Procedure ……………………………………....... 23

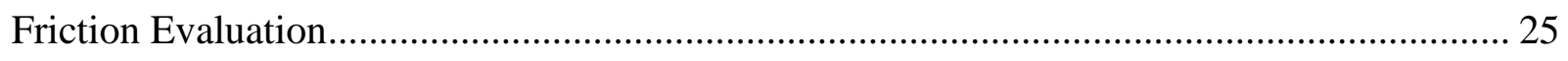

BPT Laboratory Procedure Notes …………………….................................................. 25

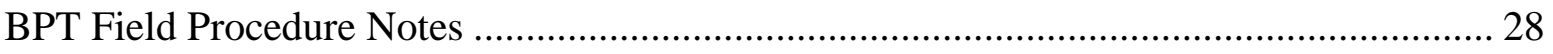

British Pendulum Number Analysis ............................................................................ 29 


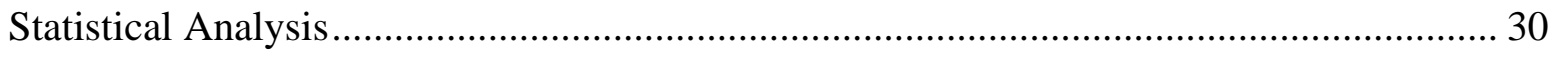

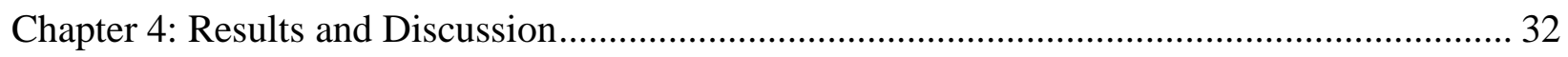

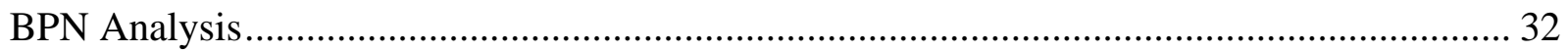

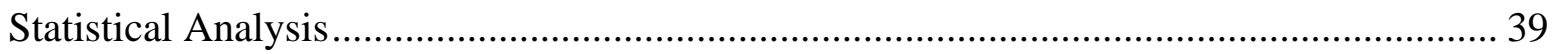

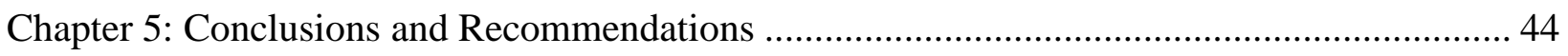

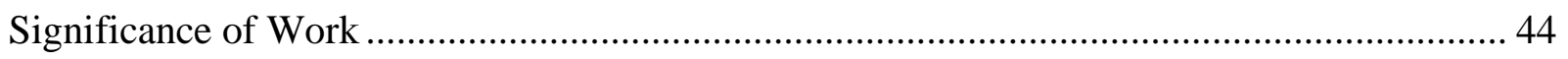

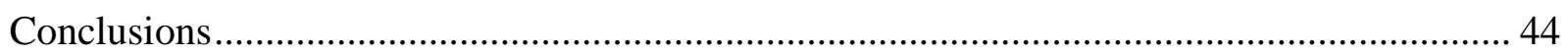

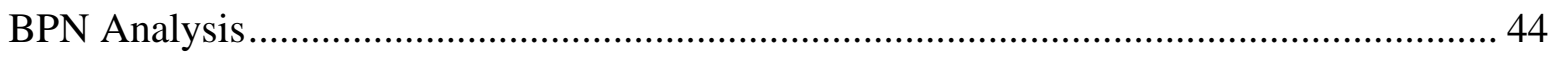

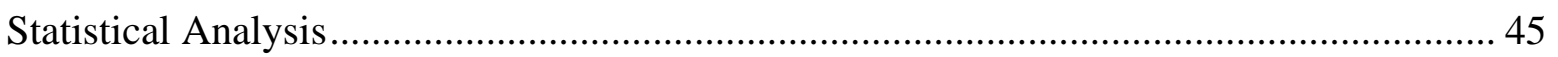

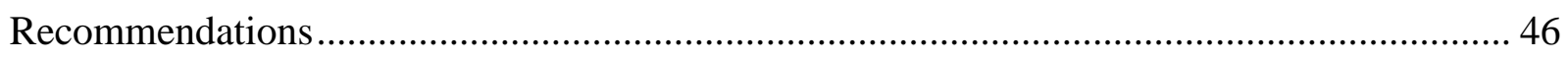

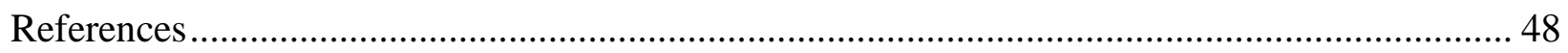

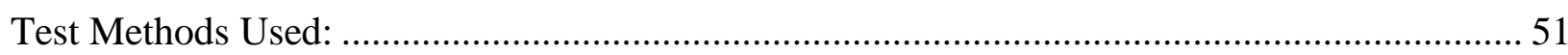

Appendix A: Mix Design, Specimen Characteristics, and Field Location Information ................ 52

Mix Design T400 Sheets................................................................................................ 52

Field Core Specimen and Location Information........................................................................ 56

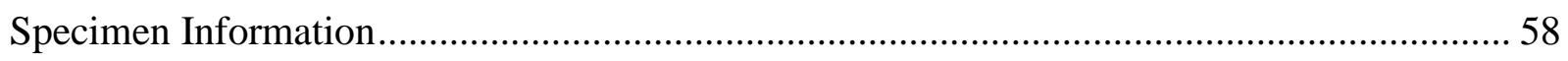

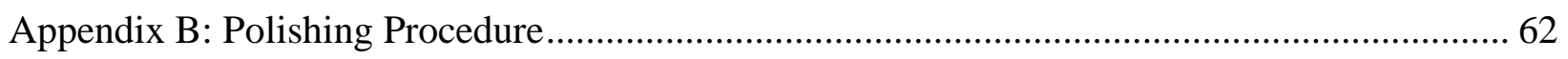

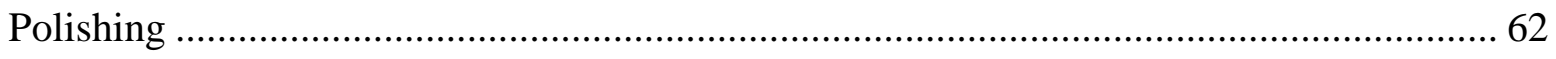

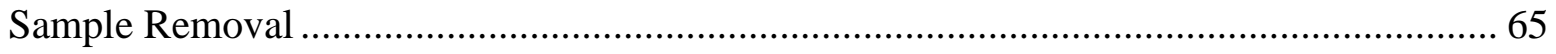

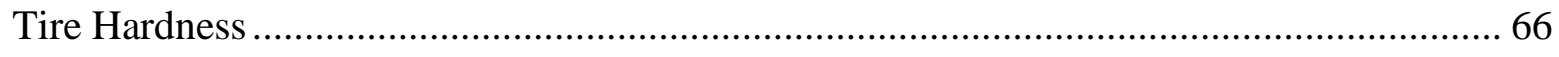

Additional Procedure Notes ............................................................................................. 67

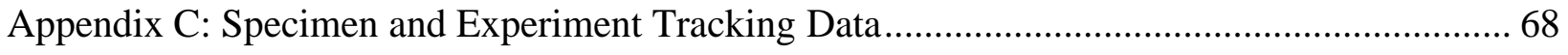

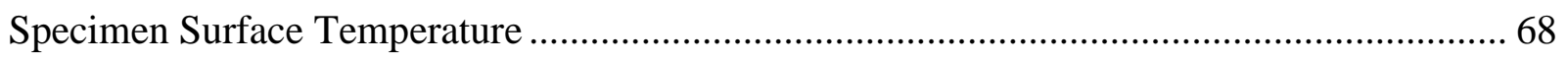

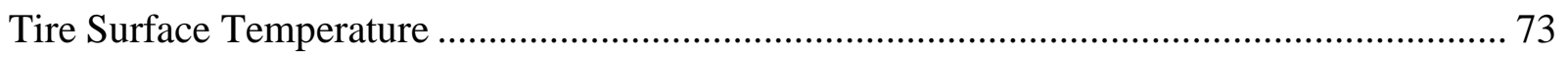

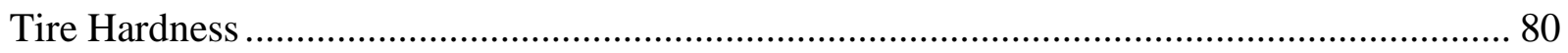




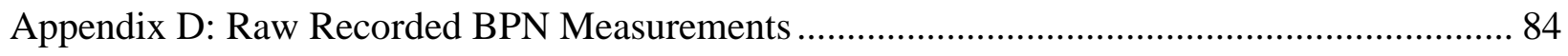

Trial 1: WVDOH Specimens (Unknown Mixture)................................................................ 84

Trial 2: JFA 12.5mm SR and WVP W1-RAP Specimens (Top Surfaces) ……………........... 86

Trial 3: JFA 12.5mm SR and WVP W1-RAP Specimens (Bottom Surfaces).......................... 88

Trial 4: WVP 12.5mm SR and Greer W1H Specimens (Top Surfaces) .................................. 90

Trial 5: WVP 12.5mm SR and Greer W1H Specimens (Bottom Surfaces) ............................. 92

Trial 6: JFA 12.5mm SR and WVP W1-RAP Specimens (Bottom Surfaces).......................... 94

Trial 8: JFA 12.5mm SR Laboratory Compacted and Field Core Specimens ........................... 98

Trial 9: JFA 12.5mm SR Field Core Specimens and Corresponding Field Measurements ... 100

Trial 10: JFA 12.5mm SR I-79 Field Measurements.......................................................... 101

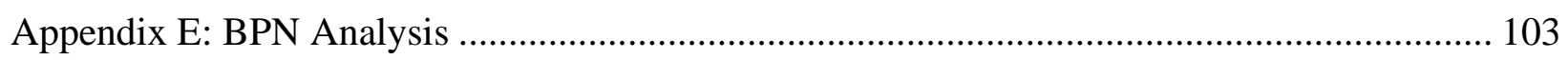

Appendix F: Statistical Analysis Data and T-test Results ....................................................... 129

Toe Angles (B55A Tire Data)......................................................................................... 129

VTM (Hoosier R80 Tire Data) .................................................................................... 130

Toe Angles (Hoosier R80 Tire Data) ............................................................................... 131

NMAS (Hoosier R80 Tire Data) ……………………………………………………..... 132

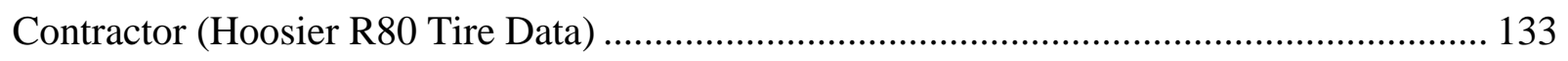

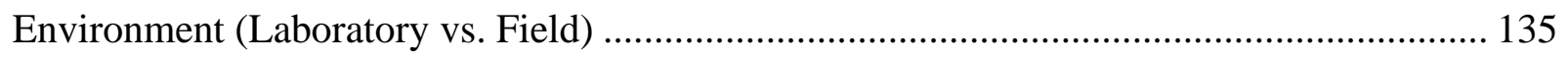




\section{List of Figures}

Figure 1: Representative Illustration of Pavement Surface Microtexture and Macrotexture

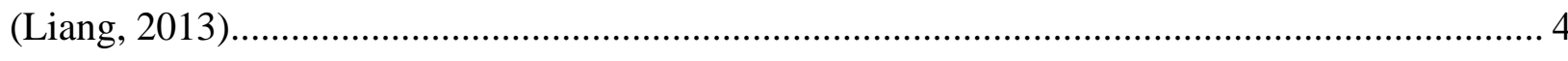

Figure 2: Minimum Skid Resistance Requirements (Lu and Steven, 2006)............................... 15

Figure 3: WVDOH Polishing Machine Overview ................................................................ 19

Figure 4: Specimen Housing and Clamping Assembly …………………………................. 20

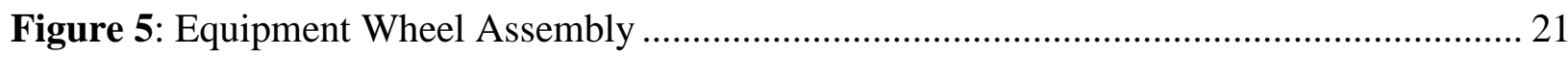

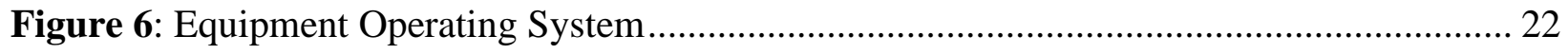

Figure 7: Recommended Spring Clip Design for BPT Slider Foot (ASTM E303-93)................ 25

Figure 8: WVU Fabricated Spring Clip on BPT Slider Foot ..................................................... 25

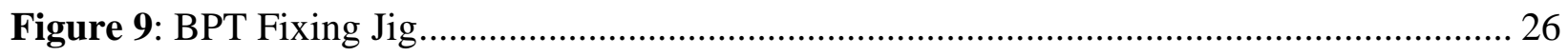

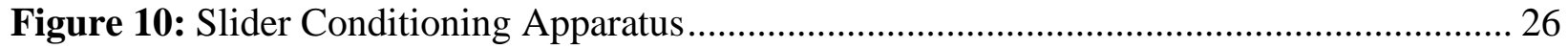

Figure 11: Wetted Specimen Surface for BPT Measurements ……………………………..... 27

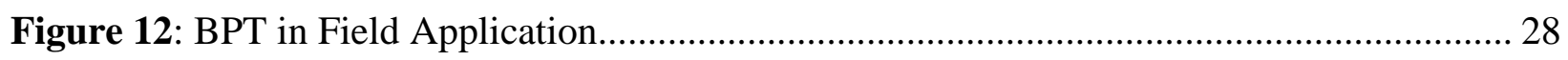

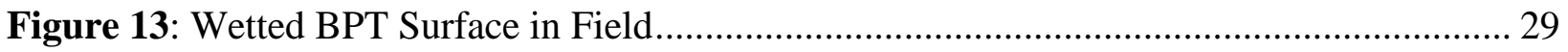

Figure 14: Average BPN Measurements for Trial 2 JFA 12.5mm SR (Top Surfaces) 8\% VTM Specimens After 48,000 Wheel Passes at Low Toe Angles and Burris B55A Tires.................... 32

Figure 15: Number of Wheel Passes vs. Average BPN Measurements for Trial 2 JFA 12.5mm

SR (Top Surfaces) at 8\% VTM Specimens at Low Toe Angles and Burris B55A Tire................ 36

Figure 16: Predicted Number of Wheel Passes to Achieve BPN of 47 for All Mixtures............. 37

Figure 17: Predicted Number of Wheel Passes at BPN of 47 for JFA 12.5mm Skid-RAP

Laboratory and Field Core Specimens........................................................................................... 37

Figure 18: Average BPN Comparison for Tested Parameters …………………………........... 40

Figure 19: T400 Sheet for JFA 12.5mm SR Mixture …………………………………...... 52

Figure 20: T400 Sheet for WVP W1-RAP Mixture …………………………………….... 53

Figure 21: T400 Sheet for WVP 12.5mm SR Mixture ............................................................. 54

Figure 22: T400 Sheet for Greer W1H Mixture .................................................................... 55

Figure 23: JFA 12.5mm SR Laboratory Compacted and Field Core Specimen Information...... 56

Figure 24: JFA 12.5mm SR I-79 Field Core and Field Measurement Location Information..... 57

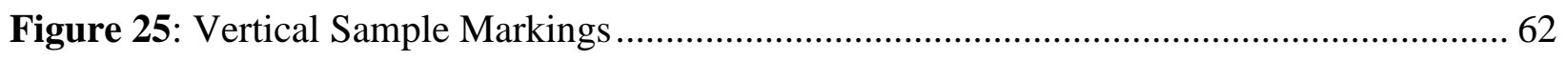


Figure 26: (a) Specimen Vertical Alignment; (b) Specimen Flushed with Surface Plate ........... 63

Figure 27: Silicon Carbide Abrasive Distribution on Specimen............................................. 63

Figure 28: (a) General Equipment Controls; (b) Variable Speed Drive ................................... 64

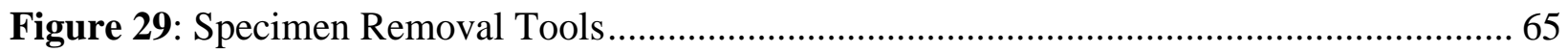

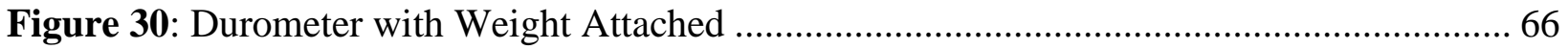

Figure 31: Trial 2 Average BPN Trend for JFA 12.5mm SR Specimens (Top Surfaces) at 4\%

VTM After 48,000 Wheel Passes 103

Figure 32: Trial 2 Prediction of Required Wheel Passes at BPN Limits for JFA $12.5 \mathrm{~mm}$ SR Specimens (Top Surfaces) at 4\% VTM After 48,000 Wheel Passes 103

Figure 33: Trial 2 Average BPN Trend for WVP W1-RAP Specimens (Top Surfaces) at 4\% VTM.. 104

Figure 34: Trial 2 Prediction of Required Wheel Passes at BPN Limits for WVP W1-RAP Specimens (Top Surfaces) at 4\% VTM After 48,000 Wheel Passes. 104

Figure 35: Trial 2 Average BPN Trend for WVP W1-RAP Specimens (Top Surfaces) at 8\% VTM After 48,000 Wheel Passes 105

Figure 36: Trial 2 Prediction of Required Wheel Passes at BPN Limits for WVP W1-RAP Specimens (Top Surfaces) at 8\% VTM After 48,000 Wheel Passes 105

Figure 37: Trial 3 Average BPN Trend for JFA 12.5mm SR Specimens (Bottom Surfaces) at 8\% VTM After 48,000 Wheel Passes 106

Figure 38: Trial 3 Prediction of Required Wheel Passes at BPN Limits for JFA 12.5mm SR Specimens (Bottom Surfaces) at 8\% VTM After 48,000 Wheel Passes 106

Figure 39: Trial 3 Average BPN Trend for JFA 12.5mm SR Specimens (Bottom Surfaces) at $4 \%$ VTM After 48,000 Wheel Passes 107

Figure 40: Trial 3 Prediction of Required Wheel Passes at BPN Limits for JFA 12.5mm SR Specimens (Bottom Surfaces) at 4\% VTM After 48,000 Wheel Passes 107

Figure 41: Trial 3 Average BPN Trend for WVP W1-RAP Specimens (Bottom Surfaces) at 4\% VTM After 48,000 Wheel Passes 108

Figure 42: Trial 3 Prediction of Required Wheel Passes at BPN Limits for WVP W1-RAP Specimens (Bottom Surfaces) at 4\% VTM After 48,000 Wheel Passes 108

Figure 43: Trial 3 Average BPN Trend for WVP W1-RAP Specimens (Bottom Surfaces) at 8\% VTM After 48,000 Wheel Passes 109 
Figure 44: Trial 3 Prediction of Required Wheel Passes at BPN Limits for WVP W1-RAP Specimens (Bottom Surfaces) at 8\% VTM After 48,000 Wheel Passes

Figure 45: Trial 4 Average BPN Trend for Greer W1H Specimens (Top Surfaces) at 8\% VTM After 48,000 Wheel Passes .... 110

Figure 46: Trial 4 Prediction of Required Wheel Passes at BPN Limits for Greer W1H Specimens (Top Surfaces) at 8\% VTM After 48,000 Wheel Passes 110

Figure 47: Trial 4 Average BPN Trend for Greer W1H Specimens (Top Surfaces) at 4\% VTM After 48,000 Wheel Passes ..... 111

Figure 48: Trial 4 Prediction of Required Wheel Passes at BPN Limits for Greer W1H Specimens (Top Surfaces) at 4\% VTM After 48,000 Wheel Passes. 111

Figure 49: Trial 4 Average BPN Trend for WVP 12.5mm SR Specimens (Top Surfaces) at 4\% VTM After 48,000 Wheel Passes

Figure 50: Trial 4 Prediction of Required Wheel Passes at BPN Limits for WVP 12.5mm SR Specimens (Top Surfaces) at 4\% VTM After 48,000 Wheel Passes 112

Figure 51: Trial 4 Average BPN Trend for WVP 12.5mm SR Specimens (Top Surfaces) at 8\% VTM After 48,000 Wheel Passes

Figure 52: Trial 4 Prediction of Required Wheel Passes at BPN Limits for WVP 12.5mm SR Specimens (Top Surfaces) at 8\% VTM After 48,000 Wheel Passes

Figure 53: Trial 5 Average BPN Trend for Greer W1H Specimens (Bottom Surfaces) at 8\% VTM After 48,000 Wheel Passes 114

Figure 54: Trial 5 Prediction of Required Wheel Passes at BPN Limits for Greer W1H Specimens (Bottom Surfaces) at 8\% VTM After 48,000 Wheel Passes 114

Figure 55: Trial 5 Average BPN Trend for Greer W1H Specimens (Bottom Surfaces) at 4\% VTM After 48,000 Wheel Passes

Figure 56: Trial 5 Prediction of Required Wheel Passes at BPN Limits for Greer W1H

Specimens (Bottom Surfaces) at 4\% VTM After 48,000 Wheel Passes 115

Figure 57: Trial 5 Average BPN Trend for WVP 12.5mm SR Specimens (Bottom Surfaces) at 4\% VTM After 48,000 Wheel Passes 116

Figure 58: Trial 5 Prediction of Required Wheel Passes at BPN Limits for WVP 12.5mm SR Specimens (Bottom Surfaces) at 4\% VTM After 48,000 Wheel Passes 116 
Figure 59: Trial 5 Average BPN Trend for WVP 12.5mm SR Specimens (Bottom Surfaces) at 8\% VTM After 48,000 Wheel Passes

Figure 60: Trial 5 Prediction of Required Wheel Passes at BPN Limits for WVP 12.5mm SR

Specimens (Bottom Surfaces) at 8\% VTM After 48,000 Wheel Passes 117

Figure 61: Trial 6 Average BPN Trend for JFA 12.5mm SR Specimens (Bottom Surfaces) at 4\% VTM After 48,000 Wheel Passes 118

Figure 62: Trial 6 Prediction of Required Wheel Passes at BPN Limits for JFA 12.5mm SR Specimens (Bottom Surfaces) at 4\% VTM After 48,000 Wheel Passes 118

Figure 63: Trial 6 Average BPN Trend for JFA 12.5mm SR Specimens (Bottom Surfaces) at 8\% VTM After 48,000 Wheel Passes 119

Figure 64: Trial 6 Prediction of Required Wheel Passes at BPN Limits for JFA 12.5mm SR Specimens (Bottom Surfaces) at 8\% VTM After 48,000 Wheel Passes 119

Figure 65: Trial 6 Average BPN Trend for WVP W1-RAP Specimens (Bottom Surfaces) at 4\% VTM After 48,000 Wheel Passes 120

Figure 66: Trial 6 Prediction of Required Wheel Passes at BPN Limits for WVP W1-RAP Specimens (Bottom Surfaces) at 4\% VTM After 48,000 Wheel Passes 120

Figure 67: Trial 6: Average BPN Trend for WVP W1-RAP Specimens (Bottom Surfaces) at 8\% VTM After 48,000 Wheel Passes

Figure 68: Trial 6 Prediction of Required Wheel Passes at BPN Limits for WVP W1-RAP

Specimens (Bottom Surfaces) at 8\% VTM After 48,000 Wheel Passes 121

Figure 69: Trial 7 Average BPN Trend for JFA 12.5mm SR Specimens (Top Surfaces) at 4\% VTM After 48,000 Wheel Passes

Figure 70: Trial 7 Prediction of Required Wheel Passes at BPN Limits for JFA 12.5mm SR Specimens (Top Surfaces) at 4\% VTM After 48,000 Wheel Passes

Figure 71: Trial 7 Average BPN Trend for JFA 12.5mm SR Specimens (Top Surfaces) at 8\% VTM After 48,000 Wheel Passes 123

Figure 72: Trial 7 Prediction of Required Wheel Passes at BPN Limits for JFA $12.5 \mathrm{~mm}$ SR Specimens (Top Surfaces) at 8\% VTM After 48,000 Wheel Passes 123

Figure 73: Trial 7 Average BPN Trend for WVP W1-RAP Specimens (Top Surfaces) at 4\% VTM After 48,000 Wheel Passes 
Figure 74: Trial 7 Prediction of Required Wheel Passes at BPN Limits for WVP W1-RAP Specimens (Top Surfaces) at 4\% VTM After 48,000 Wheel Passes

Figure 75: Trial 7 Average BPN Trend for WVP W1-RAP Specimens (Top Surfaces) at 8\% VTM After 48,000 Wheel Passes .

Figure 76: Trial 7 Prediction of Required Wheel Passes at BPN Limits for WVP W1-RAP Specimens (Top Surfaces) at 8\% VTM After 48,000 Wheel Passes 125

Figure 77: Trial 8 Average BPN Trend for JFA 12.5mm SR Laboratory Compacted Specimens After 48,000 Wheel Passes 126

Figure 78: Trial 8 Prediction of Required Wheel Passes at BPN Limits for JFA 12.5mm SR Laboratory Compacted Specimens After 48,000 Wheel Passes. 126

Figure 79: Trial 8 Average BPN Trends for JFA 12.5mm SR Field Core Specimens After 48,000 Wheel Passes

Figure 80: Trial 8 Prediction of Required Wheel Passes at BPN Limits for JFA 12.5mm SR

Field Core Specimens After 48,000 Wheel Passes.....

Figure 81:Trial 9 Average BPN Trends for JFA 12.5mm SR Field Core Specimens After 48,000 Wheel Passes 128

Figure 82: Trial 9 Prediction of Required Wheel Passes at BPN Limits for JFA 12.5mm SR Field Core Specimens After 48,000 Wheel Passes 128 


\section{List of Tables}

Table 1: Summary of Polishing Devices............................................................................ 7

Table 2: Summary of Additional Polishing Devices....................................................... 9

Table 3: Strengths and Weaknesses of Laboratory Polishing Devices (Liang, 2013) ............... 10

Table 4: Table of Field Friction Test Methods and Devices (Hall et al., 2009) ....................... 11

Table 5: Table of Lower Speed Friction Test Methods (Hall et al., 2009) ................................ 12

Table 6: Table of Methods for Pavement Texture Measurements (Hall et al., 2009)................ 13

Table 7: Recommended Minimum BPN Measurements for Various Roadway Applications (Asi, 2005)

Table 8: Suggested SN and BPN Minimum Measurements for Various Mean Traffic Speeds

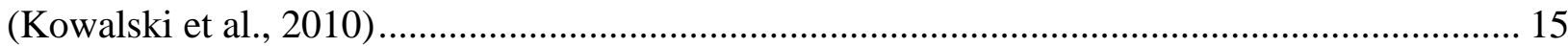

Table 9: Friction Results According to Different Asphalt Mixture Characteristics .................. 16

Table 10: Asphalt Mixture Material Information................................................................ 17

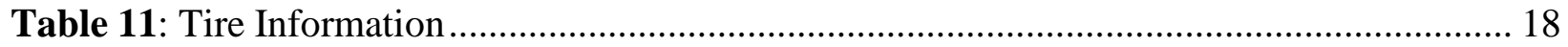

Table 12: Table of Testing Parameters for Trial Experiments ............................................. 23

Table 13: Differences Between ASTM E660 and WVDOH Polishing Equipment and Procedure

Table 14: Amount of Water Used for Specimen Surface Wetting ....................................... 27

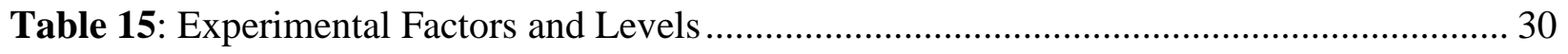

Table 16: Testing Parameter Breakdown and Potential Sample Comparisons......................... 31

Table 17: Trend line Coefficients, R2 Values, and Calculated Slopes for General Data and Predicted Number of Wheel Passes at BPN Limits of 35 and 47 ............................................ 34

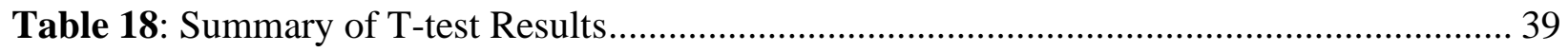

Table 19: Differences in BPN Measurements for Corresponding I-79 JFA 12.5mm SR Field

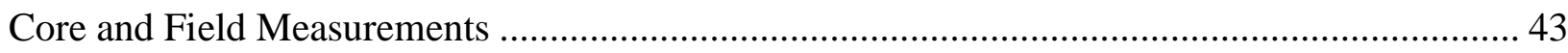

Table 20: Specimen Characteristics Catalog................................................................... 58

Table 21: Trial 2 JFA 12.5mm SR and WVP W1-RAP Initial and Final Surface Temperatures

$\left({ }^{\circ} \mathrm{F}\right)$ During Polishing Procedure 
Table 22: Trial 3 JFA 12.5mm SR and WVP W1-RAP Initial and Final Surface Temperatures

$\left({ }^{\circ} \mathrm{F}\right)$ During Polishing Procedure.

Table 23: Trial 4 WVP 12.5mm SR and Greer W1H Initial and Final Surface Temperatures $\left({ }^{\circ} \mathrm{F}\right)$

During Polishing Procedure

Table 24: Trial 5 WVP $12.5 \mathrm{~mm}$ SR and Greer W1H Initial and Final Surface Temperatures $\left({ }^{\circ} \mathrm{F}\right)$

During Polishing Procedure ................................................................................................. 70

Table 25: Trial 6 JFA 12.5mm SR and WVP W1-RAP Initial and Final Surface Temperatures

$\left({ }^{\circ} \mathrm{F}\right)$ During Polishing Procedure 70

Table 26: Trial 7 JFA 12.5mm SR and WVP W1-RAP Initial and Final Surface Temperatures

$\left({ }^{\circ} \mathrm{F}\right)$ During Polishing Procedure 71

Table 27: Trial 8 JFA 12.5mm SR Laboratory Compacted and Field Core Initial and Final

Surface Temperatures $\left({ }^{\circ} \mathrm{F}\right)$ During Polishing Procedure ......................................................... 72

Table 28: Trial 9 JFA $12.5 \mathrm{~mm}$ SR I-79 Field Core Initial and Final Surface Temperatures $\left({ }^{\circ} \mathrm{F}\right)$

During Polishing Procedure 72

Table 29: Trial 2 JFA 12.5mm SR and WVP W1-RAP Initial and Final Tire Surface

Temperatures $\left({ }^{\circ} \mathrm{F}\right)$ During Polishing Procedure 73

Table 30: Trial 3 JFA 12.5mm SR and WVP W1-RAP Initial and Final Tire Surface

Temperatures $\left({ }^{\circ} \mathrm{F}\right)$ During Polishing Procedure 73

Table 31: Trial 4 WVP 12.5mm SR and Greer W1H Initial and Final Tire Surface Temperatures

$\left({ }^{\circ} \mathrm{F}\right)$ During Polishing Procedure 74

Table 32: Trial 5 WVP 12.5mm SR and Greer W1H Initial and Final Tire Surface Temperatures

$\left({ }^{\circ} \mathrm{F}\right)$ During Polishing Procedure 75

Table 33: Trial 6 JFA 12.5mm SR and WVP W1-RAP Initial and Final Tire Surface

Temperatures $\left({ }^{\circ} \mathrm{F}\right)$ During Polishing Procedure 76

Table 34: Trial 7 JFA 12.5mm SR and WVP W1-RAP Initial and Final Tire Surface

Temperatures $\left({ }^{\circ} \mathrm{F}\right)$ During Polishing Procedure 77

Table 35: Trial 8 JFA 12.5mm SR Laboratory Compacted and Field Core Initial and Final Tire

Surface Temperatures $\left({ }^{\circ} \mathrm{F}\right)$ During Polishing Procedure 78

Table 36: Trial 9 JFA 12.5mm SR I-79 Field Core Initial and Final Tire Surface Temperatures

$\left({ }^{\circ} \mathrm{F}\right)$ During Polishing Procedure 79 
Table 37: Trial 2 JFA 12.5mm SR and WVP W1-RAP Durometer Measurements During Polishing Procedure for Burris B55A Tires. 80

Table 38: Trial 3 JFA 12.5mm SR and WVP W1-RAP Durometer Measurements During Polishing Procedure for Burris B55A Tires. 80

Table 39: Trial 4 WVP 12.5mm SR and Greer W1H Durometer Measurements During Polishing Procedure for Hoosier R80 Tires 81

Table 40: Trial 5 WVP 12.5mm SR and Greer W1H Durometer Measurements During Polishing Procedure for Hoosier R80 Tires 81

Table 41: Trial 6 JFA 12.5mm SR and WVP W1-RAP Durometer Measurements During Polishing Procedure for Hoosier R80 Tires.... 82

Table 42: Trial 7 JFA 12.5mm SR and WVP W1-RAP Durometer Measurements During Polishing Procedure for Hoosier R80 Tires.... 82

Table 43: Trial 8 JFA 12.5mm SR Laboratory and Field Core Durometer Measurements During Polishing Procedure for Hoosier R80 Tires . 83

Table 44: Trial 9 JFA 12.5mm SR I-79 Field Core Durometer Measurements During Polishing Procedure for Hoosier R80 Tires 83

Table 45: BPN Measurements for Trial 1 WVDOH Specimens (Unknown Mixture) Polished with Burris B44A Tires at Low Toe for 160,000 Wheel Passes. 84

Table 46: BPN Measurements for Trial 2 JFA 12.5mm SR and WVP W1-RAP (Top Surface)

Specimens Polished with Burris B55A Tires at Low Toe for 48,000 Wheel Passes.................. 86

Table 47: BPN Measurements for Trial 3 JFA 12.5mm SR and WVP W1-RAP (Bottom Surface) Specimens Polished with Burris B55A Tires at High Toe for 80,000 Wheel Passes 88

Table 48: BPN Measurements for Trial 4 WVP 12.5mm SR and Greer W1H (Top Surface)

Specimens Polished with Hoosier R80 Tires at High Toe for 48,000 Wheel Passes 90

Table 49: BPN Measurements for Trial 5 WVP 12.5mm SR and Greer W1H (Bottom Surface) Specimens Polished with Hoosier R80 Tires at Low Toe for 64,000 Wheel Passes. 92 Table 50: BPN Measurements for Trial 6 JFA 12.5mm SR and WVP W1-RAP (Bottom Surface) Specimens Polished with Hoosier R80 Tires at Low Toe for 48,000 Wheel Passes. 94

Table 51: BPN Measurements for Trial 7 JFA 12.5mm SR and WVP W1-RAP (Top Surface) Specimens Polished with Hoosier R80 Tires at High Toe for 48,000 Wheel Passes ..... 96 
Table 52: BPN Measurements for Trial 8 JFA 12.5mm SR Laboratory Compacted and Field Core Specimens Polished with Hoosier R80 Tires at High Toe for 48,000 Wheel Passes ..... 98

Table 53: BPN Measurements for Trial 9 JFA 12.5mm SR Field Core Specimens Polished with Hoosier R80 Tires at High Toe for 48,000 Wheel Passes .................................................... 100

Table 54: BPN Measurements for Trial 9 JFA 12.5mm SR I-79 Field Locations................... 101

Table 55: Data and Excel Output for JFA 12.5mm SR and WVP W1-RAP Polished with Burris

B55A Tires at Low and High Toe Angles 129

Table 56: Data and Excel Output for All Mixtures Polished with Hoosier R80 Tires at 4\% and $8 \%$ VTM 130

Table 57: Data and Excel Output for All Mixtures Polished with Hoosier R80 Tires at Low and High Toe Angles 131

Table 58: Data and Excel Output for All Mixtures Polished with Hoosier R80 Tires Comparing 9.5mm and $12.5 \mathrm{~mm}$ NMAS 132

Table 59: Data and Excel Output for 12.5mm Mixtures Polished with Hoosier R80 Tires Comparing JFA and WVP Contractors

Table 60: Data and Excel Output for 9.5mm Mixtures Polished with Hoosier R80 Tires

Comparing Greer and WVP Contractors 134

Table 61: Data and Excel Output Comparing Initial BPN Measurements for JFA $12.5 \mathrm{~mm}$ SR Laboratory Compacted and Corresponding Field Core Specimens Polished with Hoosier R80 Tires 135

Table 62: Data and Excel Output Comparing BPN Measurements After Polishing 48,000 Wheel Passes for JFA 12.5mm SR Laboratory Compacted and Corresponding Field Core Specimens Polished with Hoosier R80 Tires 135

Table 63: Data and Excel Output for JFA 12.5mm SR Field Core Specimens and Corresponding Average Field Measurements 136 


\section{List of Abbreviations}

AASHTO = American Association of State Highway and Transportation Officials

$\mathrm{APM}=$ Aachen Polishing Machine

ASTM $=$ American Society for Testing and Materials

$\mathrm{BPN}=$ British Pendulum Number

BPW = British Polishing Wheel

$\mathrm{BPT}=$ British Pendulum Tester

CalTrans $=$ California Department of Transportation

$\mathrm{CTM}=$ Circular Track/Texture Meter

CTPM = Circular Track Polishing Machine

DFT $=$ Dynamic Friction Tester

FHWA $=$ Federal Highway Administration

$\mathrm{G}_{\mathrm{mb}}=$ Bulk Specific Gravity

$\mathrm{G}_{\mathrm{mm}}=$ Specific Gravity of Mix

HMA = Hot Mix Asphalt

$\mathrm{I}-79=$ Interstate 79

$\mathrm{JFA}=\mathrm{J} . \mathrm{F}$. Allen Company

Micro-Deval Device (MDD)

MIWT = Michigan Indoor Wear Track

MMLS3 = Third-Scale Model Mobile Load Simulator

MDOT $=$ Michigan Department of Transportation

NCAT $=$ National Center for Asphalt Technology 
NCHRP = National Cooperative Highway Research Program

NCSU $=$ North Carolina State University

NMAS $=$ Nominal Maximum Aggregate Size

$\mathrm{N}_{\mathrm{p}}=$ Predicted Number of Wheel Passes

PSU $=$ The Pennsylvania State University

RAP $=$ Reclaimed Asphalt Pavement

SGC $=$ Superpave Gyratory Compactor

$\mathrm{SN}=$ Skid Number

SR $=$ Skid-RAP Asphalt Mixture

SSD $=$ Saturated Surface Dry

TWPD $=$ Three Wheel Polishing Device

VFT $=$ Variable Speed Friction Tester

VTM $=$ Voids in the Total Mixture (Air Void Content)

W1 = Wearing 1 Asphalt Mixture Course

WSPM $=$ Wehner $/$ Schulze Polishing Machine

$\mathrm{WV}=$ West Virginia

WVDOH $=$ West Virginia Division of Highways

$\mathrm{WVP}=$ West Virginia Paving, Inc.

$\mathrm{WVU}=$ West Virginia University 


\section{Chapter 1: Introduction}

\section{Background}

As an integral part of infrastructure, roadways provide a daily avenue for individuals to carry out various activities or trips. Because the roadway infrastructure is so important, it is imperative for engineers to maintain the safety of the public, which includes the maintenance of proper levels of skid resistance. Skid resistance poses issues for a number of crash types including non-departure and departure accidents. According to statistics stated by the Federal Highway Administration (FHWA), more than half of the 35,092 fatalities reported in 2015 were due to roadway departures (FHWA, 2016). Specific to the state of West Virginia, 214 out of a total of 303 fatalities reported in 2017 (71\%) were due to at least one vehicle departing the roadway, placing West Virginia in the top five within the United States (including Washington D.C.) for the largest percentage of fatalities associated with roadway departures (National Highway Traffic Safety Administration, 2017). While there are many factors affecting roadway departures, the lack of proper skid resistance on roadway surfaces remains a large contributing factor, especially in wet conditions (FHWA, 2016). Wet conditions contribute to the majority of roadway departure crashes, and approximately $70 \%$ could be mitigated with friction improvements (FHWA, 2016).

To combat skid resistance issues, pavement engineers have developed skid resistance surface courses, high friction treatments, as well as various other high friction developments. In order for these treatments to be successful, engineers rely heavily skid resistant aggregates. Unfortunately, the supplies of these aggregates are quickly diminishing in West Virginia, prompting a need for the West Virginia Department of Highways (WVDOH) to develop additional approaches in providing the public with proper skid resistance on asphalt pavements. Eliminating the substantial reliance on skid resistant aggregates requires research in the laboratory to measure the skid potential of hot mix asphalt (HMA) mixtures, rather than aggregate properties specifically. This approach involves the proper polishing of asphalt samples as well as measurements of a skid resistance parameter. This information can provide insight on an alternate approach in providing appropriate skid resistance properties based the asphalt concrete mixture itself. 


\section{Problem Statement}

Available skid aggregate in West Virginia is quickly depleting. While aggregates can be transported from alternate locations, it is costly and time consuming. Because of this, research is necessary to investigate the behavior of readily available aggregates as well as alternate methods of providing sufficient skid resistance on roadway surfaces. WVDOH MP 402.02.20 describes the procedure for prequalifying aggregates for skid by determining the content of polish susceptible carbonate particles in the aggregates. Field skid resistance measurements are performed using the locked skid trailer, ASTM E274. The WVDOH does not currently employ laboratory methods of measuring skid resistance for asphalt mixtures. Improved testing and research is needed in order to improve friction monitoring and predicting capabilities.

This study was performed in order to evaluate asphalt concrete mixtures with respect to skid resistance by means of a newly developed polishing machine and a British Pendulum Tester (BPT). Gathering data tracking asphalt mixtures' ability to resist polishing can provide the WVDOH and other agencies with necessary information for performing efficient laboratory testing procedures. In addition, this research will aid in developing alternative techniques for providing skid resistant mixtures and better predicting pavement performance in the future.

\section{Objectives}

There are two primary objectives for this research study. The WVDOH has not previously incorporated an accelerated polishing machine into laboratory friction testing procedures. As such, an accelerated polishing machine was developed. This lead to the first key

objective for this research, which is to develop an optimal protocol for polishing asphalt concrete samples using an accelerated polishing machine. In establishing a proper polishing procedure, the next main objective of the study was to evaluate the skid resistance of some current asphalt mixtures used across the state by analyzing BPT measurements.

In addition to the key goals established for this experiment, it is necessary to complete supplemental tasks. This primarily includes the monitoring of factors having the potential to influence skid resistance and subsequent BPT readings. With continued testing, results could provide insight on current issues in correlating laboratory and field friction measurements. This 
research could also aid in discovering alternative characteristics that influence pavement surface friction to compensate for the limited supply of skid aggregates available in the state.

\section{Scope and Limitations}

Within this experimental study, there were a few constraints regarding asphalt mixture types and polishing machine design. Testing materials were limited to plant produced mixtures as well as field and laboratory cores provided by contractors and the WVDOH. This includes the amount and type of asphalt concrete available from participating plants prior to the experiment. Because of this, sample heights also varied. While all laboratory compacted samples could be prepared or measured at specific air void contents for tracking purposes, field core air void contents could not be controlled.

The WVDOH provided the accelerated laboratory polishing machine and the BPT used for this research. Alternative methods of friction and surface texture measurements were not available. With restrictions in the equipment and variety of testing materials, overall conclusions from the experiment are also limited.

\section{Report Outline}

This thesis contains five chapters including an introduction, literature review, methodology, results and discussion, and conclusion and recommendations. Chapter 1 is the introduction, which is then followed by a literature review (Chapter 2). The literature review is comprised of three key topics: pavement surface texture and friction, laboratory polishing methods, and friction and texture evaluation. Chapter 3 corresponds to the methodology of the experiment. Chapter 4 includes general and statistical results from the experiment. Finally, a summary of conclusions and recommendations are presented in Chapter 5. Appendices comprised of additional experimental information and details are located at the end of this thesis. 


\section{Chapter 2: Literature Review}

Skid resistance is a function of vehicle parameters and the texture of the pavement surface. Other than field testing for skid resistance, e.g. the locked wheel skid trailer, pavement engineers cannot control the vehicle parameters. Hence, laboratory evaluation of asphalt mixtures is forced to focus on polishing methods and a measure of how the polishing affects either the texture or a controlled friction test. According to Panagouli and Kokkalis (1998), pavement surface texture can be categorized into three orders: microtexture, macrotexture, and megatexture. While megatexture is an important parameter to monitor for general roadway safety, skid resistance relies heavily on pavement microtexture and macrotexture (Corley-Lay, 1998). A simplified illustration of pavement microtexture and macrotexture is shown in Figure 1 (Liang, 2013).

In general terms, macrotexture is the texture caused by aggregate arrangement or spacing, while microtexture describes the texture contained on the aggregate itself on a small-scale level (“Skid Resistance," 2019). Texture variations ranging between 0.3-4.0 millimeters and 0.005-0.3 millimeters represent macrotexture and microtexture, respectively (Panagouli and Kokkalis, 1998). Within this distinction, macrotexture describes the texture allowing for excess water storage on a pavement's surface, and microtexture represents the interaction between the tire and the pavement surface (Federal Highway Administration Research and Technology, 2015). "Tirepavement friction" combines friction elements of hysteresis and adhesion. Hysteresis and adhesion correspond to macrotexture and microtexture, respectively (FHWA, 2015).

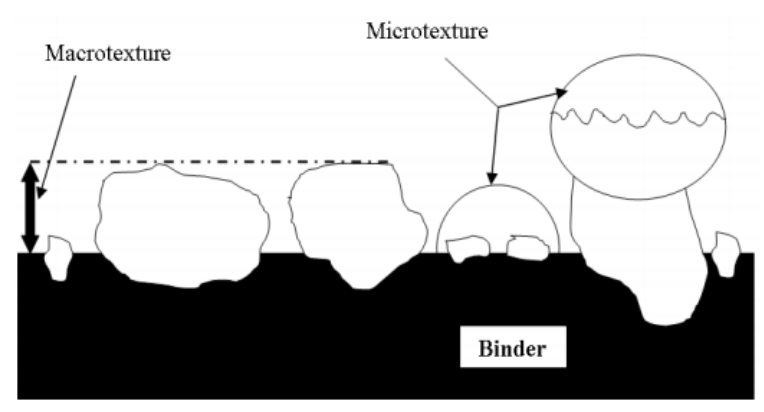

Figure 1: Representative Illustration of Pavement Surface Microtexture and Macrotexture (Liang, 2013) 
Erukulla (2011) found that microtexture defines the magnitude of skid resistance at low speeds, while macrotexture controls the slope of skid resistance versus speed relationship. The FHWA issues guidelines for roadway departure safety; the compliance by state agencies requires monitoring and maintaining proper pavement surface friction. While most state agencies employ high speed methods to measure skid resistance, there are techniques in measuring skid resistance in low speed applications, which are important for monitoring pavement surface texture.

\section{Polishing}

During the life of a pavement, the surface becomes polished due to the environment, number of wheel passes, and durability of the pavement surface materials. The polishing action occurring in the field can be demonstrated under laboratory conditions with accelerated polishing devices, which is the focus of this research. Polishing devices are categorized in terms of aggregate, HMA, or aggregate and HMA polishing.

Generally speaking, polishing is discussed in terms of the polishing of aggregates. With respect to aggregates, polishing can be described as "the wearing down and smoothing of the small surface irregularities of the aggregate under traffic loading" (Gandhi et al., 1991). Aggregate polishing devices include the British Polishing Wheel (BPW) and the Michigan Indoor Wear Track (MIWT). The ability of aggregates to provide a skid resistant surface can also be evaluated with the Micro-Deval Device (MDD) given in (Greer and Heitzman, 2017) and the Insoluble Residue Test (WVDOH, 2018). While the polishing of aggregates is important to understand the polishing of asphalt mixtures, it is not the focus of this research, and will not be further discussed.

HMA polishing devices include the National Center for Asphalt Technology (NCAT) Three Wheel Polishing Device (TWPD), Ohio Polisher, and Third-Scale Model Mobile Load Simulator (MMLS3). There are also devices to polish either HMA or aggregates, including the Pennsylvania State University (PSU) Reciprocating Polishing Machine, Wehner/Schulze Polishing Machine (WSPM), Aachen Polishing Machine (APM), and North Carolina State University (NCSU) Circular Track Polishing Machine (CTPM).

Hall et al. (2009) recognize the three most relevant polishing devices as the NCSU CTPM, MIWT, and NCAT TWPD. The NCSU CTPM is the only device with a published 
ASTM Standard (ASTM E660). The Ohio Polisher (Liang, 2013) is a recent development since the completion of the NCHRP report. For this research, the NCSU, NCAT, and Ohio polishing devices were primarily considered for equipment development due to their relevancy in current standards and usage. Table 1 is Hall et al.'s (2009) summary of polishing devices. Table 2 is a summary of the WS and Ohio polishing devices compiled from Freil et al. (2013) and Liang (2013). Table 3 provides additional information on the strengths and weaknesses of laboratory polishing equipment (Liang, 2013).

\section{Friction and Texture Evaluation}

\section{Friction Measuring Devices}

Friction measuring devices provide measurements at either high or low speeds. Hall et al., 2009 recognizes four primary types of high-speed devices: locked-wheel, side-force, variable-slip, and fixed-slip. Descriptions of test methods and corresponding devices are summarized by Hall et al. (2009) in Table 4. The locked-wheel skid trailer (ASTM E274) is identified as the most used method in the U.S. (Hall et al., 2009). This is also the current method used by the WVDOH.

Table 5 (Hall et al., 2009) describes additional lower speed test methods including the BPT and the Dynamic Friction Tester (DFT). The BPT is specified in ASTM E303 and is the friction measuring equipment used for this research. While the BPT was a favored low-speed friction measuring device in the past, the DFT is often used in current methods (Hall et al., 2009). It is typically used by NCAT along with the CTM device (Hall et al., 2009). The CTM is specific to pavement texture evaluation. Generally speaking, texture measuring methods rely on volumetric or laser techniques for evaluating surface friction. Methods for pavement surface texture measurements are described by Hall et al., 2009 and displayed in Table 6. However, texture measuring devices were not available for this research. 
Table 1: Summary of Polishing Devices

\begin{tabular}{|c|c|c|c|c|}
\hline $\begin{array}{c}\text { Polishing } \\
\text { Method/D } \\
\text { evice }\end{array}$ & Standard & $\begin{array}{c}\text { Testing } \\
\text { Material }\end{array}$ & Description & Equipment \\
\hline $\begin{array}{c}\text { Michigan } \\
\text { Indoor } \\
\text { Wear } \\
\text { Track } \\
\text { (MIWT) }\end{array}$ & N/A & Aggregates & $\begin{array}{l}\text { The MIWT is a wheel-type } \\
\text { accelerated polishing } \\
\text { device for coarse } \\
\text { aggregates. the wear track } \\
\text { design allows for two tires } \\
\text { to pass over samples } \\
\text { placed in a horizontal } \\
\text { circular path. Once } \\
\text { polished, aggregates are } \\
\text { evaluated for an aggregate } \\
\text { wear index by measuring } \\
\text { the frictional tire resistance } \\
\text { on a wetted sample surface } \\
\text { (MDOT, 2019). }\end{array}$ & rukull \\
\hline $\begin{array}{c}\text { NCSU } \\
\text { Circular } \\
\text { Track } \\
\text { Polishing } \\
\text { Machine } \\
\text { (CTPM) }\end{array}$ & $\begin{array}{l}\text { ASTM } \\
\text { E660 }\end{array}$ & HMA & $\begin{array}{l}\text { The CTPM provides } \\
\text { polishing action by rotating } \\
\text { wheels on twelve samples } \\
\text { in a circular track } \\
\text { formation. ASTM E660 } \\
\text { specifies the use of four } \\
\text { smooth, } 11 \text { x } 6.00 \text { x } 5 \text { inch } \\
\text { tires rotated over samples } \\
\text { at a rate of } 30 \text { rpm. } \\
\text { Vertical force on the tires } \\
\text { is controlled with weights } \\
\text { (Mullen et al., 1977). Per } \\
\text { E660-90, slab samples are } \\
\text { cut into triangular sections } \\
\text { to allow the samples to fit } \\
\text { together into a circular } \\
\text { track. E660-90 indicates an } \\
\text { 8-hour sufficient polishing } \\
\text { time, or 57,600 cycles. A } \\
\text { variable speed friction } \\
\text { tester (VFT) and a BPT } \\
\text { were used to measure } \\
\text { friction (Mullen et al., } \\
\text { 1977). }\end{array}$ & (ASTM E660-90 \\
\hline
\end{tabular}




\begin{tabular}{|c|l|l|}
\hline NCAT & & $\begin{array}{l}\text { The NCAT TWPD } \\
\text { polishes asphalt concrete } \\
\text { slabs by the rotation of } \\
\text { three wheels on the asphalt } \\
\text { surface. Laboratory } \\
\text { samples are prepared using } \\
\text { a rolling kneading } \\
\text { compactor, resulting in 20- } \\
\text { inch square slabs, which } \\
\text { are 2 inches in thickness } \\
\text { (NCAT, 2016). } \\
\text { Supplemental friction } \\
\text { measurements are typically } \\
\text { performed with a dynamic } \\
\text { friction tester (DFT). } \\
\text { Texture can be measured } \\
\text { with the Circular Texture } \\
\text { Meter (CTM). }\end{array}$ \\
Polishing & N/A & HMA \\
Device & TWP) &
\end{tabular}


Table 2: Summary of Additional Polishing Devices

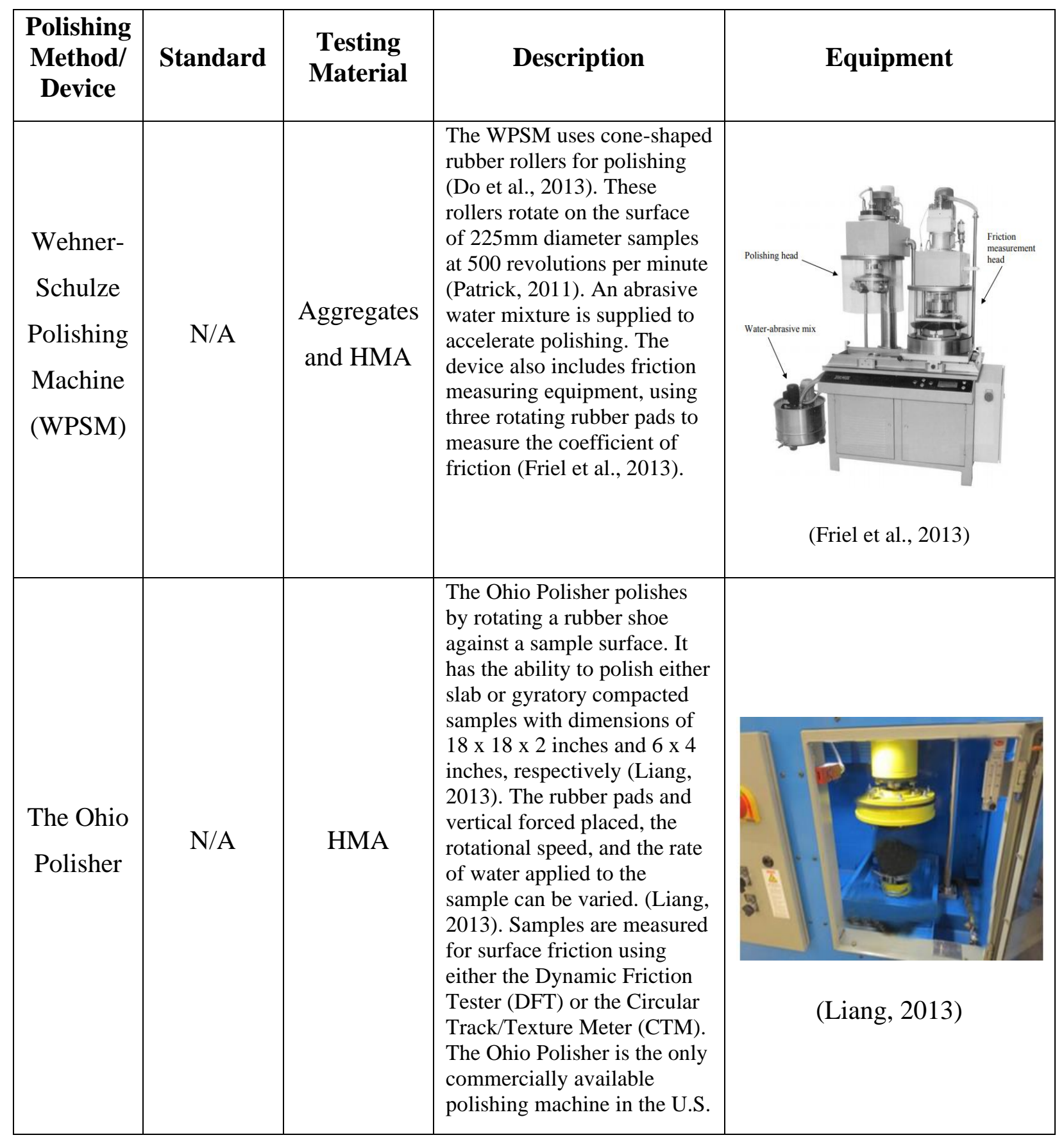


Table 3: Strengths and Weaknesses of Laboratory Polishing Devices (Liang, 2013)

\begin{tabular}{|c|c|c|c|}
\hline Device & Strengths & Weaknesses & Specifications \\
\hline \multicolumn{4}{|c|}{ Polishing Devices for Aggregates } \\
\hline $\begin{array}{l}\text { British Polishing } \\
\text { Wheel }\end{array}$ & $\begin{array}{c}\text { Accelerated } \\
\text { polishing for lab } \\
\text { testing. } \\
\text { Bench sized. }\end{array}$ & $\begin{array}{c}\text { Used for aggregates } \\
\text { only }\end{array}$ & ASTM D3319 \\
\hline $\begin{array}{l}\text { Michigan Indoor } \\
\text { Wear Track }\end{array}$ & Close to real world. & $\begin{array}{c}\text { Specimen } \\
\text { preparation is } \\
\text { cumbersome and } \\
\text { time-consuming. } \\
\text { Used for aggregate } \\
\text { only. }\end{array}$ & MDOT \\
\hline Micro-Deval & $\begin{array}{c}\text { Effective for } \\
\text { polishing aggregates } \\
\text { in a short time. }\end{array}$ & $\begin{array}{c}\text { Used for aggregates } \\
\text { only }\end{array}$ & $\begin{array}{c}\text { AASHTO T327- } \\
05 / \text { Tex-461-A }\end{array}$ \\
\hline \multicolumn{4}{|c|}{ Polishing Devices for HMA } \\
\hline $\begin{array}{l}\text { NCAT Polishing } \\
\text { Machine }\end{array}$ & $\begin{array}{l}\text { Sized to match DFT } \\
\text { and CTM. } \\
\text { Can be used in the } \\
\text { lab or in the field. }\end{array}$ & $\begin{array}{l}42 \text { hours to } \\
\text { complete the test. } \\
\text { Specimen } \\
\text { preparation is } \\
\text { cumbersome and } \\
\text { labor intensive. }\end{array}$ & NCAT \\
\hline \multicolumn{4}{|c|}{ Polishing Devices for Both } \\
\hline $\begin{array}{l}\text { NCSU Wear and } \\
\text { Polishing Machine }\end{array}$ & $\begin{array}{l}\text { No need for water } \\
\text { or grinding } \\
\text { compounds. }\end{array}$ & $\begin{array}{c}\text { Polishes a relatively } \\
\text { small area. }\end{array}$ & ASTM E660 \\
\hline $\begin{array}{c}\text { Wehner/Schulz } \\
\text { Polishing Machine }\end{array}$ & $\begin{array}{l}\text { Can conduct } \\
\text { polishing and } \\
\text { friction } \\
\text { measurements }\end{array}$ & $\begin{array}{c}\text { Unable to handle } \\
\text { gyratory-compacted } \\
\text { specimens. }\end{array}$ & ASTM E1393 \\
\hline $\begin{array}{c}\text { Penn State } \\
\text { Reciprocating } \\
\text { Polishing Machine }\end{array}$ & $\begin{array}{l}\text { Portable. } \\
\text { Can be used in the } \\
\text { lab or in the field. }\end{array}$ & $\begin{array}{c}\text { Polishes a relatively } \\
\text { small area. } \\
\text { Fallen into disuse. }\end{array}$ & Do et al., 2006 \\
\hline
\end{tabular}


Table 4: Table of Field Friction Test Methods and Devices (Hall et al., 2009)

\begin{tabular}{|c|c|c|c|c|}
\hline Test Method & Measurement Index & Applications & Advantages & Disadvantages \\
\hline Locked-Wheel & $\begin{array}{l}\text { The measured resistive drag force and } \\
\text { the wheel load applied to the pavement } \\
\text { are used to compute the coefficient of } \\
\text { friction, } \mu \text {. Friction is reported as } \\
\text { friction number }(F N) \text { or skid number } \\
(S N) \text {. }\end{array}$ & $\begin{array}{l}\text { Field testing } \\
\text { (straight } \\
\text { segments). } \\
\\
\text { Network-level } \\
\text { friction } \\
\text { monitoring. }\end{array}$ & $\begin{array}{l}\text { Well developed and } \\
\text { very widely used in } \\
\text { the U.S. More than } \\
40 \text { states use locked- } \\
\text { wheel devices. } \\
\text { Systems are user } \\
\text { friendly, relatively } \\
\text { simple, and not time } \\
\text { consuming. }\end{array}$ & $\begin{array}{l}\text { Can only be used on } \\
\text { straight segments (no } \\
\text { curves, T-sections, or } \\
\text { roundabouts). Can miss } \\
\text { slippery spots because } \\
\text { measurements are } \\
\text { intermittent. }\end{array}$ \\
\hline Side-Force & $\begin{array}{l}\text { The side force perpendicular to the } \\
\text { plane of rotation is measured and } \\
\text { averaged to compute the Mu Number, } \\
M u N \text {, or the sideways force coefficient, } \\
\text { SFC. }\end{array}$ & \begin{tabular}{|l|} 
Field testing \\
straight \\
sections, curves, \\
steep grades. \\
Data in \\
different \\
applications \\
should be \\
collected \\
separately.
\end{tabular} & $\begin{array}{l}\text { Relatively well } \\
\text { controlled skid } \\
\text { condition similar to } \\
\text { fixed-slip device } \\
\text { results. } \\
\text { Measurements are } \\
\text { continuous } \\
\text { throughout a test } \\
\text { pavement section. } \\
\text { Method is commonly } \\
\text { used in Europe. }\end{array}$ & $\begin{array}{l}\text { Very sensitive to road } \\
\text { irregularities (potholes, } \\
\text { cracks, etc.) which can } \\
\text { destroy tires quickly. } \\
\text { Mu-Meter is primarily } \\
\text { only used for airports in } \\
\text { the U.S. }\end{array}$ \\
\hline Fixed-Slip & $\begin{array}{l}\text { The measured resistive drag force and } \\
\text { the wheel load applied to the pavement } \\
\text { are used to compute the coefficient of } \\
\text { friction, } \mu \text {. Friction is reported as } F N \text {. }\end{array}$ & 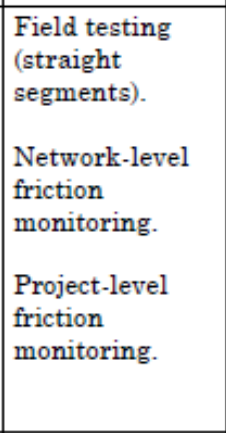 & $\begin{array}{l}\text { Continuous, high } \\
\text { resolution friction } \\
\text { data collected. }\end{array}$ & $\begin{array}{l}\text { Fixed-slip devices take } \\
\text { readings at a specified } \\
\text { slip speed. Their slip } \\
\text { speeds do not always } \\
\text { coincide with the critical } \\
\text { slip speed value, } \\
\text { especially over ice- and } \\
\text { snow-covered surfaces. } \\
\text { Uses large amounts of } \\
\text { water in continuous } \\
\text { mode. } \\
\text { Requires skillful data } \\
\text { reduction. }\end{array}$ \\
\hline Variable-Slip & $\begin{array}{l}\text { When used for variable-slip } \\
\text { measurements, the system provides a } \\
\text { chart of the relationship between slip } \\
\text { friction number and slip speed. The } \\
\text { resulting indices are: } \\
\text { - Longitudinal slip friction number } \\
\text { - Peak slip friction number } \\
\text { - Critical slip ratio } \\
\text { - Slip ratio } \\
\text { - Slip to skid friction number } \\
\text { - Estimated friction number } \\
\text { - Rado Shape factor } \\
\text { When used for locked-wheel } \\
\text { measurements, the system provides } \\
F N \text { values. }\end{array}$ & $\begin{array}{l}\text { Field testing } \\
\text { (straight or } \\
\text { curved } \\
\text { segments). } \\
\text { Network-level } \\
\text { friction } \\
\text { monitoring. } \\
\\
\text { Project-level } \\
\text { friction } \\
\text { monitoring. }\end{array}$ & $\begin{array}{l}\text { Can provide } \\
\text { continuously any } \\
\text { desired fixed or } \\
\text { variable slip friction } \\
\text { results. } \\
\text { Can provide the Rado } \\
\text { shape factor for } \\
\text { detailed evaluation. }\end{array}$ & $\begin{array}{l}\text { Large, complex } \\
\text { equipment with high } \\
\text { maintenance costs and } \\
\text { complex data processing } \\
\text { and analysis needs. } \\
\text { Uses large amounts of } \\
\text { water in continuous } \\
\text { mode. }\end{array}$ \\
\hline
\end{tabular}


Table 5: Table of Lower Speed Friction Test Methods (Hall et al., 2009)

\begin{tabular}{|c|c|c|c|c|}
\hline Test Method & $\begin{array}{c}\text { Associated } \\
\text { Standard } \\
\end{array}$ & Description & & Equipment \\
\hline $\begin{array}{c}\text { Stopping } \\
\text { Distance } \\
\text { Measurement }\end{array}$ & ASTM E 445 & $\begin{array}{l}\text { The pavement surface is } \\
\text { sprayed with water until } \\
\text { saturated. A vehicle is driven } \\
\text { at a constant speed ( } 40 \mathrm{mi} / \mathrm{hr} \\
\text { [ } 64 \mathrm{~km} / \mathrm{hr} \text { specified) over the } \\
\text { surface. The wheels are } \\
\text { locked, and the distance the } \\
\text { vehicle travels while reaching } \\
\text { a full stop is measured. } \\
\text { Alternatively, different } \\
\text { speeds and a fully engaged } \\
\text { antilock braking system } \\
\text { (ABS) have been used. }\end{array}$ & $\begin{array}{l}\text { A passenger car or light } \\
\text { truck (at least } 3,200 \mathrm{lb} \\
\text { [preferable equipped } \\
\text { with a heavy-duty } \\
\text { suspension system]) is } \\
\text { specified. The braking } \\
\text { system should be } \\
\text { capable of full and } \\
\text { sustained lockup. Tires } \\
\text { should be ASTM E } 501 \\
\text { ribbed design. }\end{array}$ & \\
\hline $\begin{array}{l}\text { Deceleration } \\
\text { Rate } \\
\text { Measurement }\end{array}$ & $\begin{array}{c}\text { ASTM E } \\
2101\end{array}$ & $\begin{array}{l}\text { Testing is typically done in } \\
\text { winter contaminated } \\
\text { conditions. While traveling } \\
\text { at standard speed ( } 20 \text { to } 30 \\
\text { mi/hr [ } 32 \text { to } 48 \mathrm{~km} / \mathrm{hr}]) \text {, the } \\
\text { brakes are applied to lock the } \\
\text { wheels, until deceleration } \\
\text { rates can be measured. The } \\
\text { deceleration rate is recorded } \\
\text { for friction computation. }\end{array}$ & $\begin{array}{l}\text { Mechanical or electronic } \\
\text { equipment, shown at } \\
\text { right, is installed on } \\
\text { any vehicle to measure } \\
\text { and record deceleration } \\
\text { rate during stopping. }\end{array}$ & \\
\hline $\begin{array}{c}\text { Portable } \\
\text { Testers }\end{array}$ & $\begin{array}{c}\text { ASTM E } 303 \\
\text { ASTM E } \\
1911\end{array}$ & $\begin{array}{l}\text { Portable testers can be used } \\
\text { to measure the frictional } \\
\text { properties of pavement } \\
\text { surfaces. These testers use } \\
\text { pendulum or slider theory to } \\
\text { measure friction in a } \\
\text { laboratory or in the field. } \\
\text { The British Pendulum Tester } \\
\text { (BPT) produces a low-speed } \\
\text { sliding contact between a } \\
\text { standard rubber slider and } \\
\text { the pavement surface. The } \\
\text { elevation to which the arm } \\
\text { swings after contact provides } \\
\text { an indicator of the frictional } \\
\text { properties. Data from five } \\
\text { readings are typically } \\
\text { collected and recorded by } \\
\text { hand. } \\
\text { The Dynamic Friction Tester } \\
\text { measures the torque } \\
\text { necessary to rotate three } \\
\text { small, spring-loaded, rubber } \\
\text { pads in a circular path over } \\
\text { the pavement surface at } \\
\text { speeds from } 3 \text { to } 55 \text { mi/hr ( } 5 \\
\text { to } 89 \mathrm{~km} / \mathrm{hr} \text { ). Water is } \\
\text { applied at } 0.95 \text { gal/min ( } 3.6 \\
\text { L/min) during testing. } \\
\text { Rotational speed, rotational } \\
\text { torque, and downward load } \\
\text { are measured and recorded } \\
\text { electronically. }\end{array}$ & $\begin{array}{l}\text {-The BPT is manually } \\
\text { operated and } \\
\text { documented, as shown } \\
\text { at top right. } \\
\text {-The DFT, shown at } \\
\text { bottom right, is a } \\
\text { modular system that is } \\
\text { controlled } \\
\text { electronically. Results } \\
\text { are typically recorded at } \\
12,24,36 \text {, and } 48 \text { mi/hr } \\
\text { (20, } 40,60 \text {, and } 80 \\
\text { km/hr), and the speed, } \\
\text { friction relationship can } \\
\text { be plotted. It fits in the } \\
\text { trunk of a car and is } \\
\text { accompanied by a water } \\
\text { tank and portable } \\
\text { computer. }\end{array}$ & \\
\hline
\end{tabular}


Table 6: Table of Methods for Pavement Texture Measurements (Hall et al., 2009)

\begin{tabular}{|c|c|c|c|c|}
\hline $\begin{array}{c}\text { Test Method/ } \\
\text { Equipment }\end{array}$ & $\begin{array}{c}\text { Associated } \\
\text { Standard }\end{array}$ & Description & & Equipment \\
\hline $\begin{array}{l}\text { Sand Patch } \\
\text { Method (SPM) }\end{array}$ & $\begin{array}{l}\text { ASTM E } 965 \text {, } \\
\text { ISO } 10844\end{array}$ & $\begin{array}{l}\text { This volumetric-based spot } \\
\text { test method provides the } \\
\text { mean depth of pavement } \\
\text { surface macro-texture. The } \\
\text { operator spreads a known } \\
\text { volume of glass beads in a } \\
\text { circle onto a cleaned surface } \\
\text { and determines the diameter } \\
\text { and subsequently mean } \\
\text { texture depth }(M T D) \text {. }\end{array}$ & $\begin{array}{l}\text { Equipment includes: } \\
\text { Wind screen, } 1.5 \text { in }^{3} \\
\left(25,000 \mathrm{~mm}^{3}\right) \\
\text { container, scale, } \\
\text { brush, and disk (2.5- } \\
\text { to } 3 \text {-in [ } 60 \text { - to } 65 \text { - } \\
\text { mm] diameter). } \\
\text { ASTM D } 1155 \text { glass } \\
\text { beads. }\end{array}$ & \\
\hline $\begin{array}{l}\text { Outflow Meter } \\
\text { (OFM) }\end{array}$ & ASTM E 2380 & $\begin{array}{l}\text { This volumetric test method } \\
\text { measures the water drainage } \\
\text { rate through surface texture } \\
\text { and interior voids. It } \\
\text { indicates the hydroplaning } \\
\text { potential of a surface by } \\
\text { relating to the escape time of } \\
\text { water beneath a moving tire. } \\
\text { Correlations with other } \\
\text { texture methods have also } \\
\text { been developed. }\end{array}$ & $\begin{array}{l}\text { Equipment is a } \\
\text { cylinder with a } \\
\text { rubber ring on the } \\
\text { bottom and an open } \\
\text { top. Sensors } \\
\text { measure the time } \\
\text { required for a known } \\
\text { volume of water to } \\
\text { pass under the seal } \\
\text { or into the } \\
\text { pavement. }\end{array}$ & \\
\hline $\begin{array}{c}\text { Circular } \\
\text { Texture Meter } \\
\text { (CTM) }\end{array}$ & ASTM E 2157 & $\begin{array}{l}\text { This non-contact laser device } \\
\text { measures the surface texture } \\
\text { in an } 11.25 \text {-in }(286-\mathrm{mm}) \\
\text { diameter circular profile of } \\
\text { the pavement surface at } \\
\text { intervals of } 0.034 \text { in }(0.868 \\
\text { mm), matching the } \\
\text { measurement path of the } \\
\text { DFT. It rotates at } 20 \mathrm{ft} / \mathrm{min} \\
(6 \mathrm{~m} / \mathrm{min}) \text { and provides } \\
\text { profile traces and mean } \\
\text { profile depth }(M P D) \text { for the } \\
\text { pavement surface. }\end{array}$ & $\begin{array}{l}\text { Equipment includes } \\
\text { a water supply, } \\
\text { portable computer, } \\
\text { and the texture } \\
\text { meter device. }\end{array}$ & \\
\hline
\end{tabular}

\section{Friction Criteria}

Transportation agencies provide recommendations for minimum skid numbers (SN) using skid trailers in the field. However, the BPT was the only friction measuring device available for this research. There are limited reports providing minimum skid requirements in terms of British Pendulum Numbers (BPN). Asi (2005) provides values for varying roadway applications, listed in Table 7. The California Department of Transportation (CalTrans) display plotted minimum BPT measurements for both Virginia DOT and British standards (Lu and 
Steven, 2006), Figure 2. Kowalski et al. (2010) compare minimum SN and BPN measurements for various mean traffic speeds of roadways in Table 8 .

Table 7: Recommended Minimum BPN Measurements for Various Roadway Applications (Asi, 2005)

\begin{tabular}{lll}
\hline Category & Type of site & $\begin{array}{l}\text { Minimum skid resistance value (surface } \\
\text { wet) }\end{array}$ \\
\hline A & $\begin{array}{l}\text { Difficult sites such as: } \\
\text { (i) Roundabouts } \\
\text { (ii) Bends with radius less than } 150 \mathrm{~m} \text { on unrestricted } \\
\text { (iii) Gradients, } 1 \text { in } 20 \text { or steeper, of lengths greater than } 100 \mathrm{~m}\end{array}$ \\
& $\begin{array}{l}\text { (iv) Approaches to traffic lights on unrestricted roads } \\
\text { B }\end{array}$ & $\begin{array}{l}\text { Motorways, trunk and class } 1 \text { roads and heavily trafficked roads in urban areas (carrying more } \\
\text { than } 2000 \text { vehicles per day) }\end{array}$ \\
C & All other sites & 45 \\
\hline
\end{tabular}

Note: For category A and B sites where speed of traffic is high (in excess of $95 \mathrm{~km} / \mathrm{h}$ ) an additional requirement is a minimum texture depth of $0.65 \mathrm{~mm}$. 

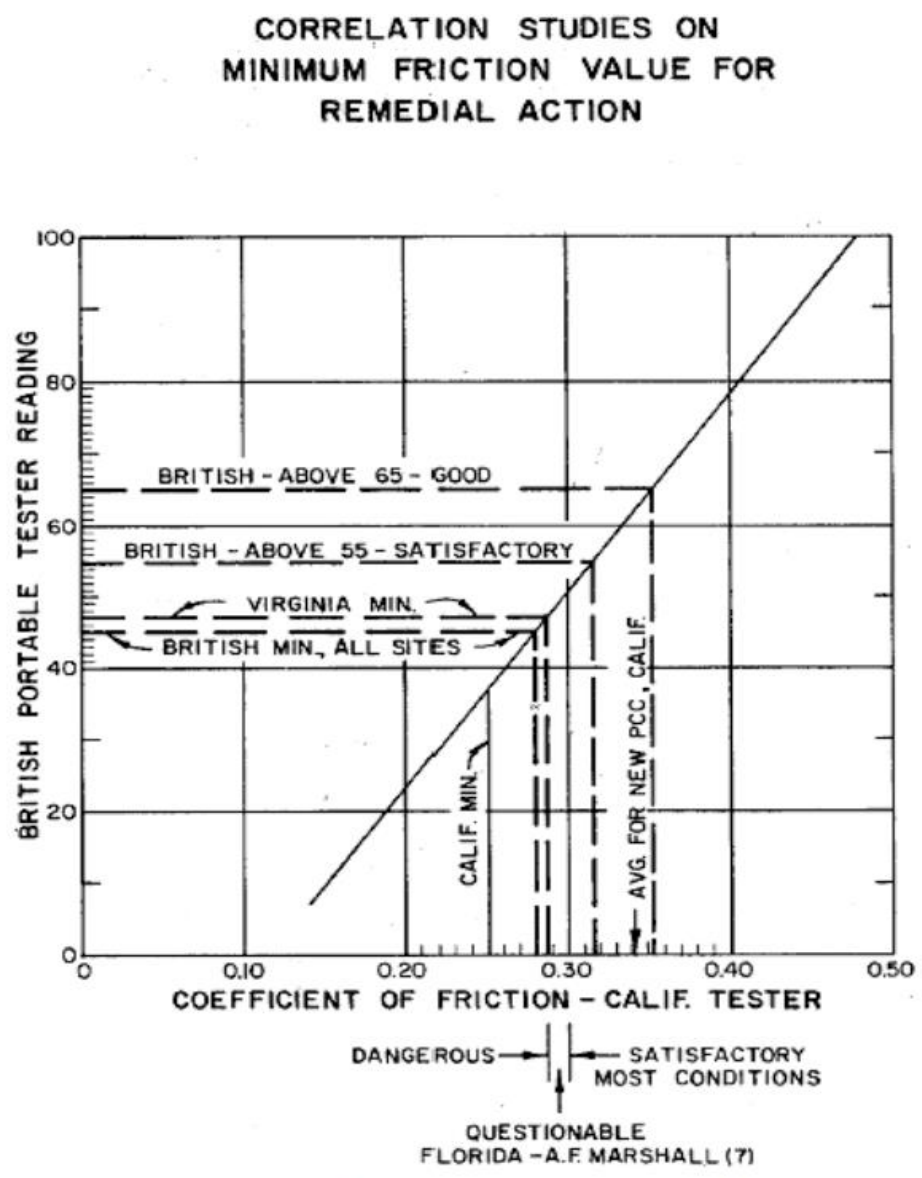

Figure 11: Correlation of California Skid Tester and British Portable Tester. (8)

Figure 2: Minimum Skid Resistance Requirements (Lu and Steven, 2006)

Table 8: Suggested SN and BPN Minimum Measurements for Various Mean Traffic Speeds (Kowalski et al., 2010)

\begin{tabular}{ccc}
\hline $\begin{array}{c}\text { Mean Traffic Speed, } \\
\mathrm{km} / \mathrm{h}\end{array}$ & $\begin{array}{c}\text { Skid Number, } \\
\text { SN }^{\mathrm{a}}\end{array}$ & $\begin{array}{c}\text { British Pendulum Number, } \\
\text { BPN }\end{array}$ \\
\hline 48 & 31 & 35 \\
64 & 33 & 40 \\
81 & 37 & 45 \\
97 & 41 & 50 \\
113 & 46 & --- \\
129 & 51 & --- \\
\hline
\end{tabular}

${ }^{a}$ ASTM E-274 friction trailer test conducted at $64 \mathrm{~km} / \mathrm{h}$ using rib tire

\section{Asphalt Mixture Friction Characteristics}

There are several asphalt mixture characteristics that influence pavement skid resistance. Characteristics discussed in this thesis include: air void content (VTM), aggregate type, 
aggregate size, aggregate gradation, binder content, and asphalt mixture type. A general increase in pavement friction with the addition of skid aggregates and textural differences is reported throughout literature. The effects of skid aggregate are indicated by Kowalski et al. (2010), Do et al. (2007), Erukulla (2011) and Asi (2005), especially with slag. Textural differences from VTM, aggregate size, and aggregate gradation are reported to increase skid resistance according to Liang (2013) and Hall et al. (2009). Table 9 summarizes the effects of mixture characteristics on pavement friction measurements from various reports.

Table 9: Friction Results According to Different Asphalt Mixture Characteristics

\begin{tabular}{|c|c|c|c|}
\hline $\begin{array}{c}\text { Mix } \\
\text { Characteristic }\end{array}$ & Testing Details & Friction Observation & Reported By \\
\hline \multirow[t]{2}{*}{ VTM } & $\begin{array}{l}\text { Specimens at } 0.8 \%, 2.8 \% \text {, and } \\
5.4 \% \text { VTM }\end{array}$ & $\begin{array}{l}\text { Statistical difference } \\
\text { between friction values }\end{array}$ & Liang, 2013 \\
\hline & Increase VTM & Increase friction values & Liang, 2013 \\
\hline \multirow{4}{*}{ Aggregate Type } & $\begin{array}{l}\text { Presence of carbonate, steel } \\
\text { slag, or quartzite }\end{array}$ & Increase friction values & Kowalski et al., 2010 \\
\hline & $\begin{array}{l}\text { Comparison of aggregate } \\
\text { specimens and field cores } \\
\text { composed of identical } \\
\text { aggregates }\end{array}$ & $\begin{array}{l}\text { Pavement friction } \\
\text { corresponds to aggregate } \\
\text { friction }\end{array}$ & Do et al., 2007 \\
\hline & $\begin{array}{l}\text { Decrease friction aggregate } \\
\text { amount }\end{array}$ & Decrease friction values & Erukulla, 2011 \\
\hline & $\begin{array}{l}\text { Comparison of Marshall, } \\
\text { Superpave, slag, and SMA } \\
\text { specimens }\end{array}$ & $\begin{array}{l}\text { Highest friction values } \\
\text { for slag specimens }\end{array}$ & Asi, 2005 \\
\hline \multirow{3}{*}{ Aggregate Size } & Increase aggregate size & Increase friction values & Kowalski et al., 2010 \\
\hline & Decrease aggregate size & Increase friction values & Do et al., 2007 \\
\hline & Increase aggregate size & $\begin{array}{l}\text { Increase macrotexture, } \\
\text { increasing friction }\end{array}$ & Hall et al., 2009 \\
\hline \multirow{2}{*}{$\begin{array}{l}\text { Aggregate } \\
\text { Gradation }\end{array}$} & $\begin{array}{l}\text { Coarse aggregate gradation } \\
\text { (SMA) }\end{array}$ & $\begin{array}{l}\text { Increased field friction } \\
\text { values }\end{array}$ & Asi, 2005 \\
\hline & $\begin{array}{l}\text { Larger open, gap, or uniform } \\
\text { graded mix }\end{array}$ & $\begin{array}{l}\text { Increase texture depth, } \\
\text { increasing friction }\end{array}$ & Hall et al., 2009 \\
\hline \multirow{2}{*}{ Binder Content } & $\begin{array}{l}\text { Increased binder content, } \\
\text { Marshall specimens }\end{array}$ & Decrease friction values & Asi, 2005 \\
\hline & $\begin{array}{l}\text { SMA specimens at } 6.9 \% \\
\text { binder content }\end{array}$ & Low friction values & Asi, 2005 \\
\hline \multirow[t]{2}{*}{ Mix Type } & $\begin{array}{l}\text { Comparison of Marshall, } \\
\text { Superpave, and SMA } \\
\text { specimens }\end{array}$ & $\begin{array}{l}\text { Increased friction values } \\
\text { for Superpave }\end{array}$ & Asi, 2005 \\
\hline & SMA specimens & $\begin{array}{l}\text { Increased field friction } \\
\text { values }\end{array}$ & Asi, 2005 \\
\hline
\end{tabular}




\section{Chapter 3: Research Methodology}

The two main objectives of this research were to develop a polishing procedure for asphalt samples with a newly developed laboratory accelerated polishing machine and subsequently evaluate some current surface mixtures approved by the WVDOH.

\section{Materials}

Because the primary focus of this research was the development of laboratory polishing protocol, only a total of four asphalt mixtures were obtained for testing. Asphalt mixtures used for this research include J.F. Allen 12.5mm Skid-RAP (JFA 12.5mm SR), West Virginia Paving 12.5mm Skid-RAP (WVP 12.5mm SR), West Virginia Paving W1-RAP (WVP W1-RAP), and Greer W1 Heavy (Greer W1H). Additional specimens prepared at the WVDOH laboratory for preliminary testing were also used, but the mixture type is unknown. Table 10 provides a summary of the four primary mixtures used for this research. Mixture T400 sheets are provided in Appendix A.

Table 10: Asphalt Mixture Material Information

\begin{tabular}{|c|c|c|c|c|}
\hline Plant Name & Plant Location & Mix NMAS & Mix Type & T400 Number \\
\hline J. F. Allen Company (JFA) & Lorentz, WV & $12.5 \mathrm{~mm}\left(1 / 2^{\prime \prime}\right)$ & Skid-RAP (SR) & 1462122 \\
\hline $\begin{array}{c}\text { West Virginia Paving, Inc. } \\
\text { (WVP) }\end{array}$ & Dunbar, WV & $12.5 \mathrm{~mm}\left(1 / 2^{\prime \prime}\right)$ & Skid-RAP (SR) & 1462115 \\
\hline $\begin{array}{c}\text { West Virginia Paving, Inc. } \\
\text { (WVP) }\end{array}$ & Huntington, WV & $9.5 \mathrm{~mm}\left(3 / 8^{\prime \prime}\right)$ & $\begin{array}{c}\text { Wearing 1-RAP } \\
\text { (W1-RAP) }\end{array}$ & 1436773 \\
\hline $\begin{array}{c}\text { Greer Asphalt (Greer) } \\
\text { Greer, WV }\end{array}$ & $9.5 \mathrm{~mm}\left(3 / 8^{\prime \prime}\right)$ & $\begin{array}{c}\text { Wearing 1 } \\
\text { Heavy (W1H) }\end{array}$ & 1360465 \\
\hline
\end{tabular}

There were also several tire substitutions made throughout the experiment due to either poor performance results or availability. Table 11 lists the tires used in this experiment. Tire hardness was monitored throughout the experiment to ensure that polishing was consistent throughout. The procedure used for measuring tire hardness is in Appendix B. Measurements remained consistent throughout and are provided in Appendix C. 
Table 11: Tire Information

\begin{tabular}{|c|c|c|c|}
\hline Manufacturer & Type & Size & $\begin{array}{c}\text { Shore A } \\
\text { Hardness }\end{array}$ \\
\hline Burris & B44A & $11 \times 6-5.00^{\prime \prime}$ & 75 \\
\hline Burris & B55A & $11 \times 6-5.00 "$ & 84 \\
\hline Hoosier & R80 & $11 \times 6-5.00^{\prime \prime}$ & 79 \\
\hline
\end{tabular}

\section{Equipment}

The WVDOH hired a machinist to fabricate the polishing machine based on ASTM E660-90. The primary features include:

- Polishes 12 samples at once

- Four tires for polishing

- Variable rotation speed

- Accommodates variable sample heights and gyratory compacted or field core samples

- Maintains sample height settings for extraction

The polishing machine components are displayed in Figures 3 through 6 . 


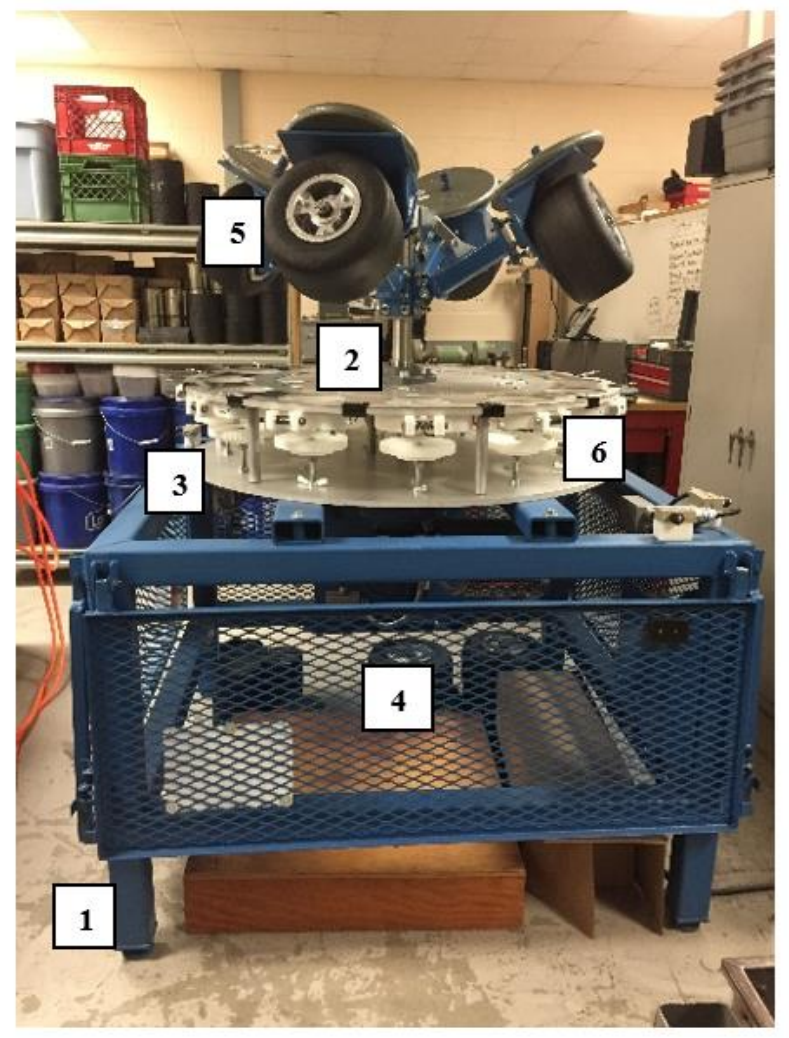

(a) Side View

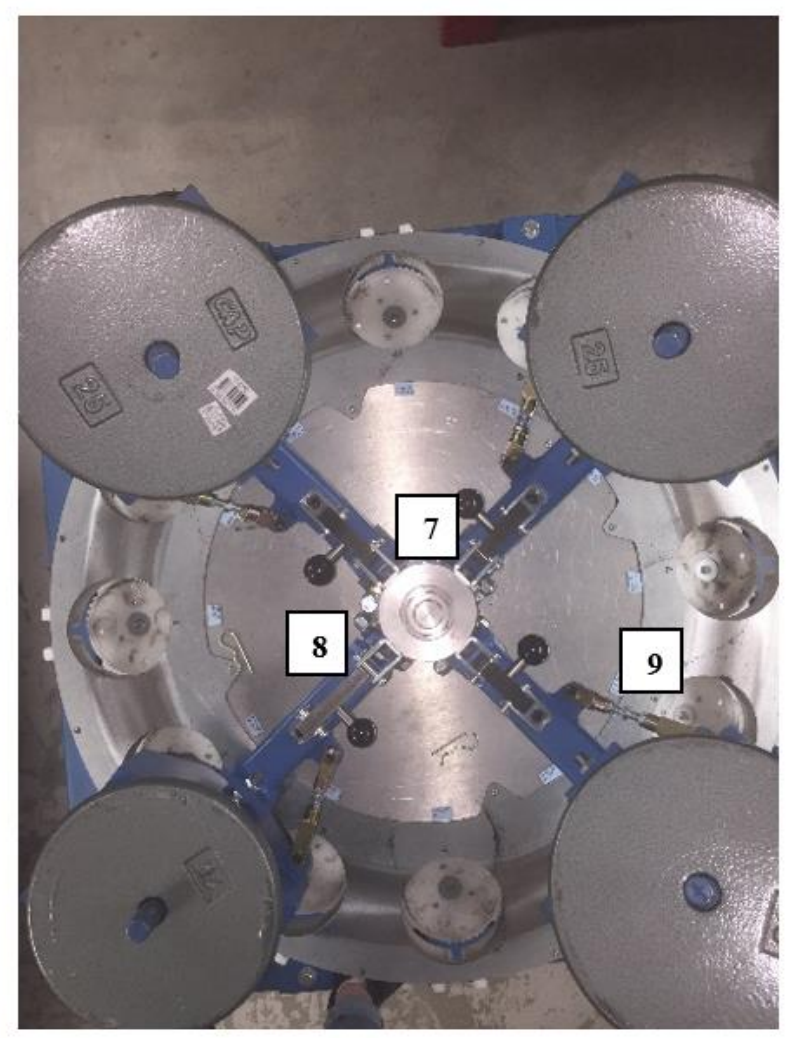

(b) Top View

Figure 3: WVDOH Polishing Machine Overview

1. Equipment frame

2. Upper surface plate, Figure 4

3. Lower base plate

4. Safety guards, Figure 6

5. Rotating wheel assembly, Figure 5

6. Specimen housing components

7. Central shaft for rotation

8. Support pin for wheel assembly in upright position

9. Tie rod connection for toe angle adjustments 

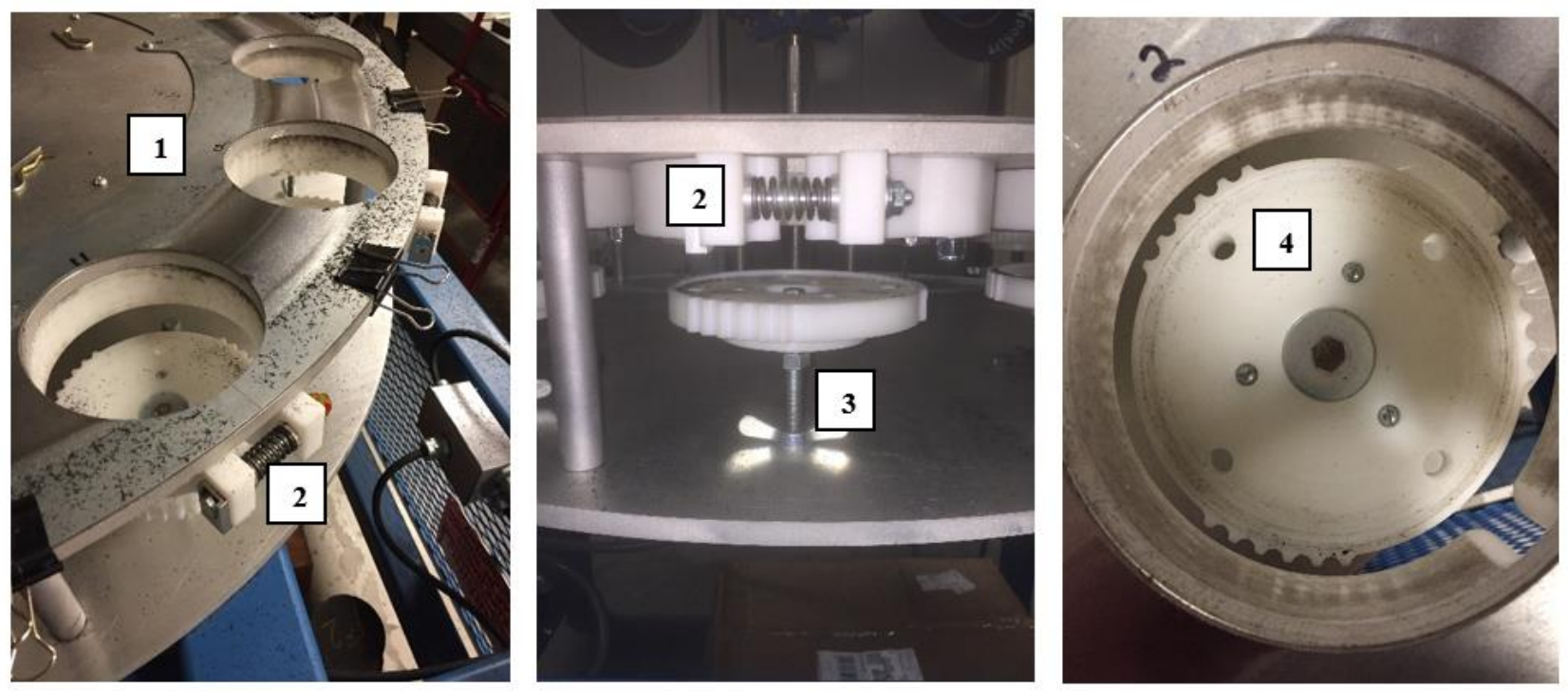

Figure 4: Specimen Housing and Clamping Assembly

1. Upper surface plate

2. Clamping assembly

3. Specimen height adjustment

4. Specimen extraction openings 

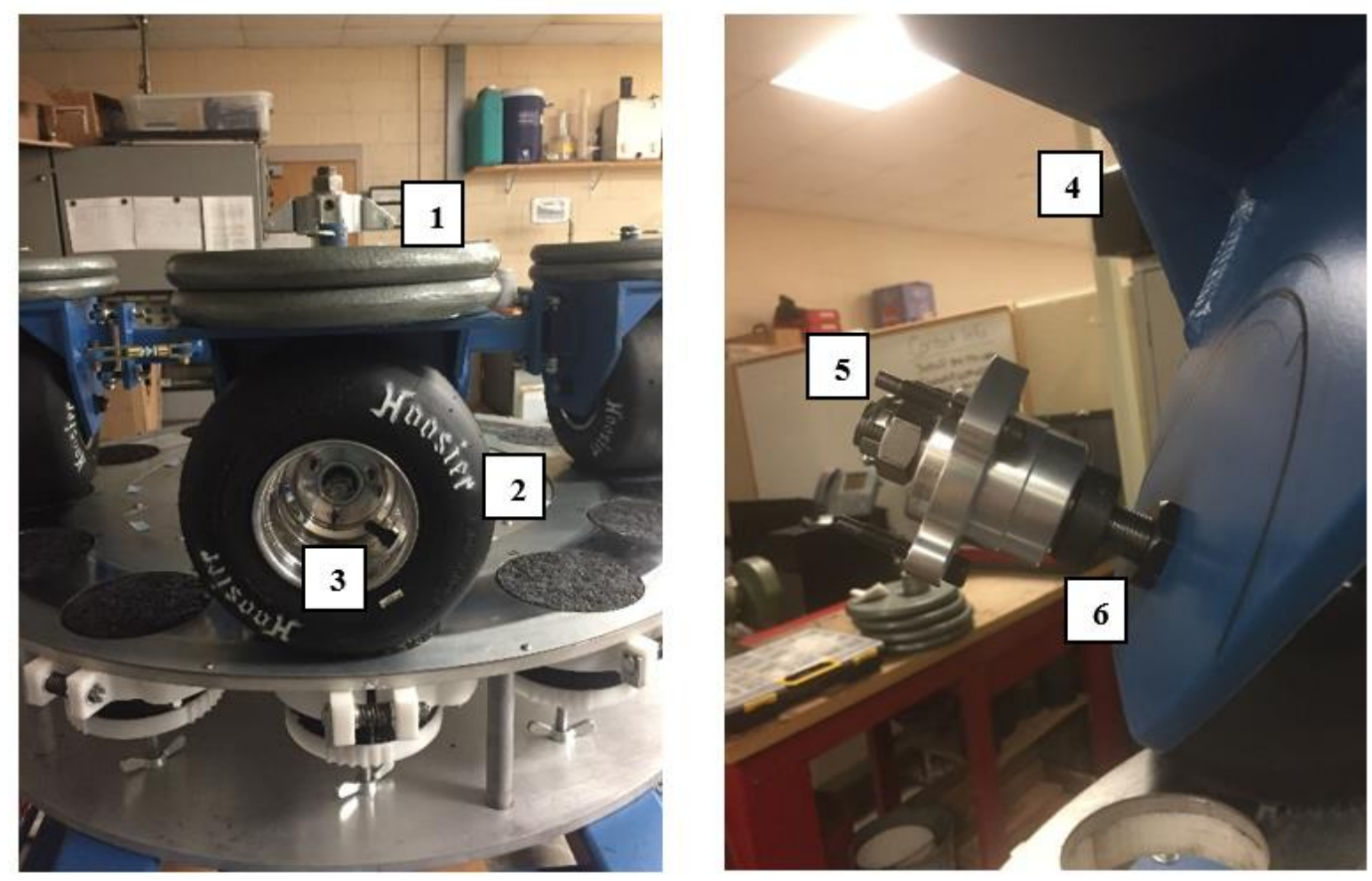

Figure 5: Equipment Wheel Assembly

1. Weights for wheel loading (50 pounds total)

2. Tires (size $11 \times 6-5.00$ inches)

3. Wheel hub and bolt pattern

4. Wheel fender

5. Castellated nut for wheel bearing preload

6. Wheel axle 

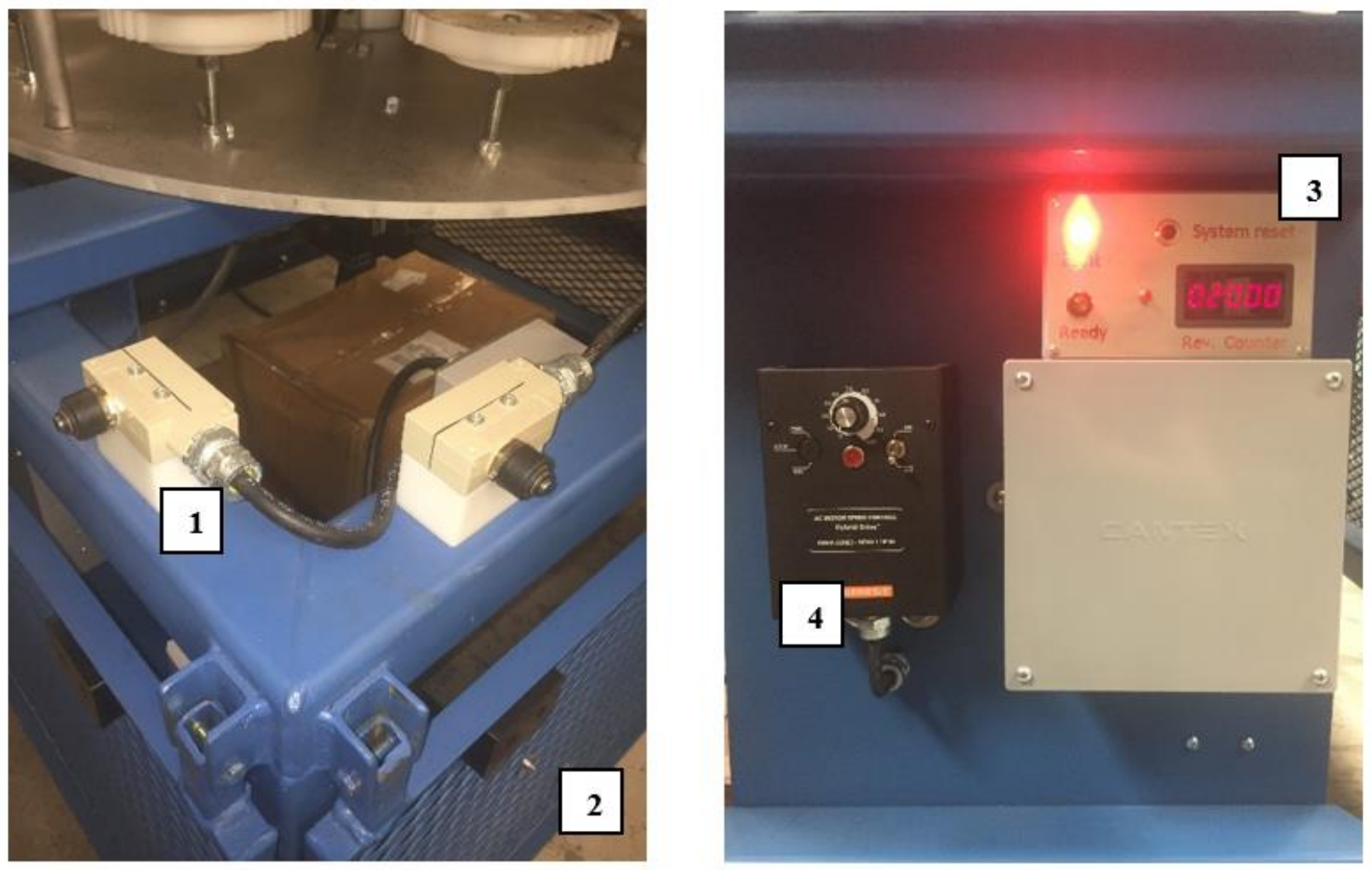

Figure 6: Equipment Operating System

1. Interlock switch mechanism

2. Safety guards

3. Polishing cycle counter

4. Variable frequency drive for 3-phase gear motor control

\section{Sample Preparation}

Three primary steps for the sample preparation process included inventory, compaction, and volumetric verifications. Mixtures were first inventoried and randomized to reduce bias. Specimens were compacted to a height of 90mm using a Superpave Gyratory Compactor (SGC) according to AASHTO T-312. Target air void contents of $4 \% \pm 0.5$ and $8 \% \pm 0.5$ were verified using the saturated surface dry (SSD) method, AASHTO T-166. Three replicates of two mixtures and two VTMs were prepared, totaling 12 specimens for each polishing session. 


\section{Development of Accelerated Polishing Procedure}

The polishing procedure was developed through a sequence of trials as summarized in Table 12. Various parameters that could affect the polishing process were evaluated with the different trials. The first trial evaluated the operation of the polisher; no friction data were recorded. The second and third trials used tires that were harder than the original set. Both sets of tires used for trials one through three were provided by the WVDOH. An attempt to purchase another set of the Burris tires found they were no longer produced. Hoosier R80 tires were selected as the replacement based on their properties and availability. These tires were used for trials 4 to 9 . ASTM specifies toe angles of $2^{\circ}$ and $4^{\circ}$ on alternating tires. For trials 3,4 , and 7 , the toe angles were increased to $4^{\circ}$ and $8^{\circ}$ to check if the greater toe angle increases the rate of polishing. Table 13 shows differences between the equipment and procedures described in ASTM E660-90 and this research.

Table 12: Table of Testing Parameters for Trial Experiments

\begin{tabular}{|c|c|c|c|c|c|c|}
\hline Trial & $\begin{array}{c}\text { Number of } \\
\text { Maximum Wheel } \\
\text { Passes }\end{array}$ & Mixtures Tested & Test Surface & VTM & $\begin{array}{c}\text { Toe-In/Toe- } \\
\text { Out }{ }^{*}\end{array}$ & Tire Type \\
\hline 1 & 160000 & $\begin{array}{c}\text { WVDOH (Unknown } \\
\text { Mix Type) }\end{array}$ & N/A & N/A & Low Toe & Burris B44A \\
\hline 2 & 48000 & $\begin{array}{c}\text { JFA 12.5mm SR and } \\
\text { WVP W1-RAP }\end{array}$ & Top & $4 \%$ and $8 \%$ & Low Toe & Burris B55A \\
\hline 3 & 8000 & $\begin{array}{c}\text { JFA 12.5mm SR and } \\
\text { WVP W1-RAP }\end{array}$ & Bottom & $4 \%$ and $8 \%$ & High Toe & Burris B55A \\
\hline 4 & 48000 & $\begin{array}{c}\text { WVP 12.5mm SR and } \\
\text { Greer W1H }\end{array}$ & Top & $4 \%$ and $8 \%$ & High Toe & Hoosier R80 \\
\hline 5 & 64000 & $\begin{array}{c}\text { WVP 12.5mm SR and } \\
\text { Greer W1H }\end{array}$ & Bottom & $4 \%$ and $8 \%$ & Low Toe & Hoosier R80 \\
\hline 6 & 48000 & $\begin{array}{c}\text { JFA 12.5mm SR and } \\
\text { WVP W1-RAP }\end{array}$ & Bottom & $4 \%$ and $8 \%$ & Low Toe & Hoosier R80 \\
\hline 7 & 48000 & $\begin{array}{c}\text { JFA 12.5mm SR and } \\
\text { WVP W1-RAP }\end{array}$ & Top & $4 \%$ and $8 \%$ & High Toe & Hoosier R80 \\
\hline 9 & 48000 & $\begin{array}{c}\text { JFA 12.5mm SR Field } \\
\text { and Field Cores }\end{array}$ & Nores & $4 \%$ and $8 \%$ & High Toe & Hoosier R80 \\
\hline
\end{tabular}

Note:

*Low Toe $=4^{\circ}$ toed in and $2^{\circ}$ toed out, alternating; High Toe $=8^{\circ}$ toed in and $4^{\circ}$ toed out, alternating. 
Table 13: Differences Between ASTM E660 and WVDOH Polishing Equipment and Procedure

\begin{tabular}{|c|c|c|c|}
\hline & & ASTM E660-90 & WVDOH \\
\hline \multirow{3}{*}{ Equipment } & \multirow{2}{*}{ Tires } & Pressure $=20 \mathrm{psi}$ & Pressure $=30 \mathrm{psi}$ \\
\hline & & $\begin{array}{l}\text { Nylon smooth no- } \\
\text { pattern; 2-ply rating }\end{array}$ & Hoosier R80 \\
\hline & Wheels & $\begin{array}{l}\text { Option for studded } \\
\text { wheels }\end{array}$ & No studded wheels \\
\hline \multirow{8}{*}{ Procedure } & \multirow[t]{2}{*}{ Specimens } & $\begin{array}{l}\text { Laboratory }=6 " \\
\text { diameter, no height } \\
\text { specified; field core } \\
=6 " \text { diameter, } \\
38 \mathrm{~mm} \text { height } \\
\text { (bituminous) }\end{array}$ & $\begin{array}{l}\text { Laboratory =6" } \\
\text { diameter, } 90 \mathrm{~mm} \\
\text { height; 6" diameter } \\
\text { field core specimens } \\
\approx 90 \mathrm{~mm} \text { height if } \\
\text { possible } \\
\text { (bituminous) }\end{array}$ \\
\hline & & $\begin{array}{l}\text { Option for concrete } \\
\text { specimens }\end{array}$ & $\begin{array}{l}\text { No concrete } \\
\text { specimens }\end{array}$ \\
\hline & Abrasive & No abrasive & $\begin{array}{l}\text { Silicon Carbide } \\
\text { Powder }\end{array}$ \\
\hline & $\begin{array}{c}\text { Toe } \\
\text { Angles }\end{array}$ & $\begin{array}{l}4^{\circ} \text { toe in } 2^{\circ} \text { toe out } \\
\text { only }\end{array}$ & $\begin{array}{l}4^{\circ} \text { toe in } 2^{\circ} \text { toe out; } \\
8^{\circ} \text { toe in } 4^{\circ} \text { toe out }\end{array}$ \\
\hline & $\begin{array}{c}\text { Tire } \\
\text { Hardness }\end{array}$ & No monitoring & $\begin{array}{l}\text { Monitored with } \\
\text { durometer every } \\
4,000 / 6,000 \\
\text { revolutions } \\
(16,000 / 24,000 \\
\text { wheel passes })\end{array}$ \\
\hline & \multirow[b]{2}{*}{$\begin{array}{l}\text { Friction } \\
\text { Evaluation }\end{array}$} & $\begin{array}{l}\text { NCSU Variable } \\
\text { Speed Friction } \\
\text { Tester recommended }\end{array}$ & $\begin{array}{l}\text { British Pendulum } \\
\text { Tester (BPT) }\end{array}$ \\
\hline & & $\begin{array}{l}\text { Measurements } \\
\text { recorded at } 0,7200, \\
14400,28000, \\
43200 \text {, and } 57,600 \\
\text { wheel passes }\end{array}$ & $\begin{array}{l}\text { Measurements } \\
\text { recorded at } 0,8000, \\
16000,32000, \text { and } \\
48000 \text { wheel passes }\end{array}$ \\
\hline & $\begin{array}{l}\text { Sufficient } \\
\text { Polishing }\end{array}$ & $\begin{array}{l}57,600 \text { wheel passes } \\
(7,200 \text { wheel passes } \\
\text { per hour for } 8 \mathrm{hr})\end{array}$ & 48,000 wheel passes \\
\hline
\end{tabular}




\section{Friction Evaluation}

The procedures for calibrating and testing surface friction using the BPT were followed as described in ASTM E303-93. Arm length and center of gravity were verified; sliders were conditioned by swinging the arm ten times over dry sand paper. Each sample required five swings of the pendulum, and the first swing was not recorded. Sample surfaces were wetted prior to all swings. Sliders were replaced according to ASTM E303-93 failure criteria. There are supplementary notes significant to laboratory and field procedures in this experiment.

\section{BPT Laboratory Procedure Notes}

Supplementary information includes BPT slider preparation, general procedure specifics, and optional documentation performed throughout the experiment. These details include:

- ASTM E303-93 recommended slider spring clip, Figure 7, to reduce rotation of slider during impact by the addition of a spring clip.
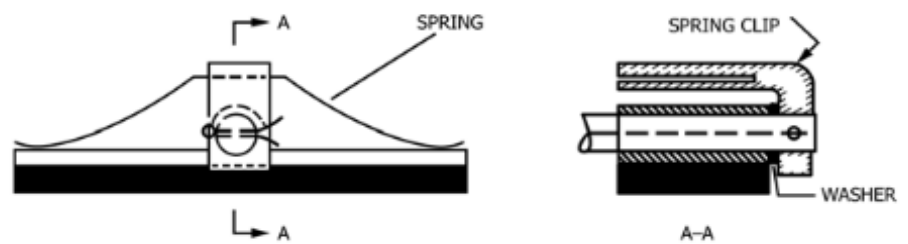

Figure 7: Recommended Spring Clip Design for BPT Slider Foot (ASTM E303-93)
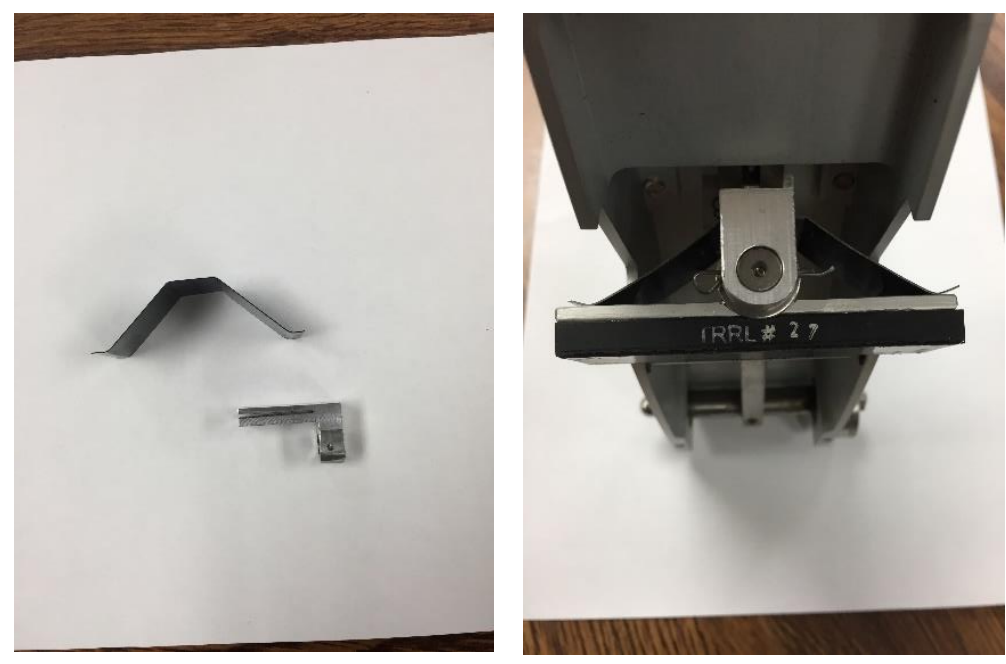

Figure 8: WVU Fabricated Spring Clip on BPT Slider Foot 
- BPT fixing jig for SGC laboratory prepared specimens, Figure 9.

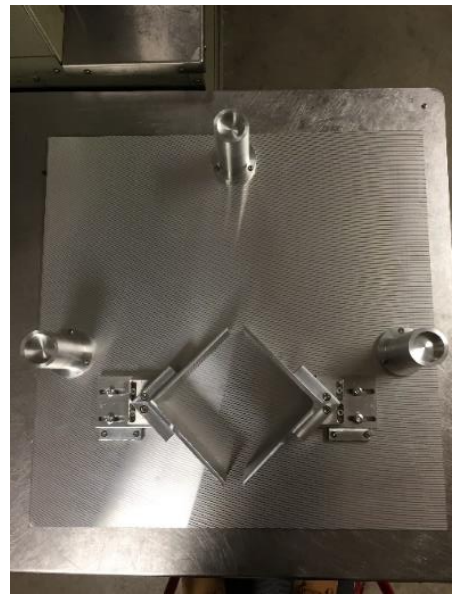

(a) Top View

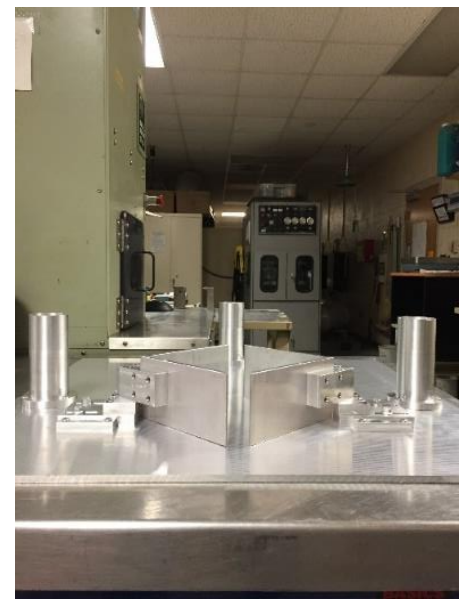

(b) Front View

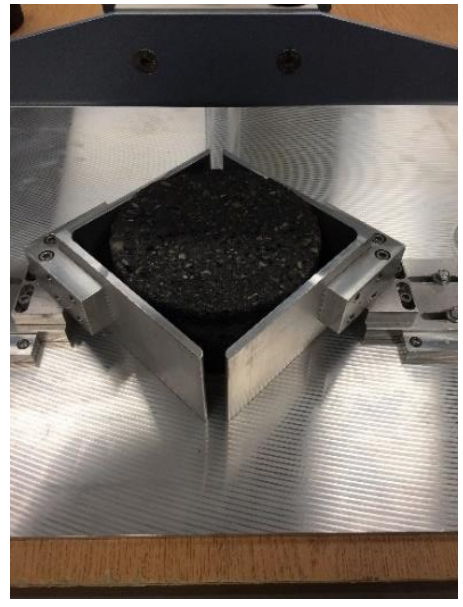

(c) Jig with sample

Figure 9: BPT Fixing Jig

- BPT slider conditioning apparatus, Figure 10.

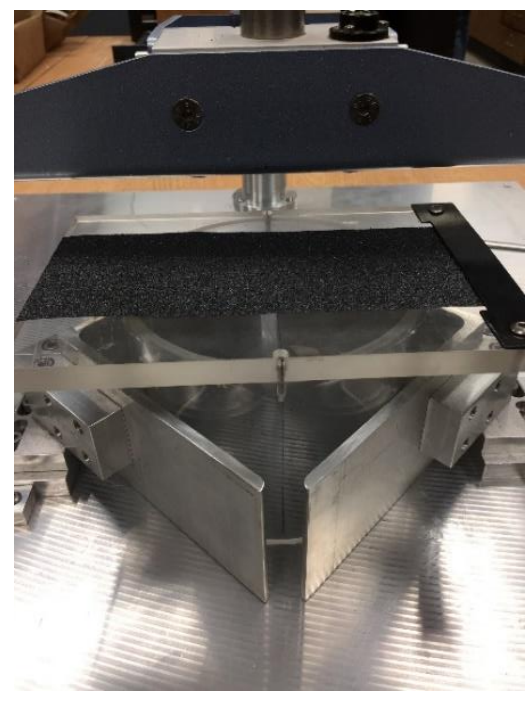

Figure 10: Slider Conditioning Apparatus 
- Consistent specimen surface wetting, described in ASTM E303-93. A spray bottle was used to spray a total of 30 sprays for the first swing of the pendulum and 5 sprays for each of the four final swings of the pendulum. Figure 12 displays a specimen following the wetting process. Table 14 provides a quantification of the amount of water used for this process. Approximately $60 \%$ of the sprayed water did not cover the specimen surface. This was calculated by subtracting dry paper towel weight from the overspray water weight captured on the towels after wetting a specimen. This is represented in Table 13 as the actual volume of water on the surface.

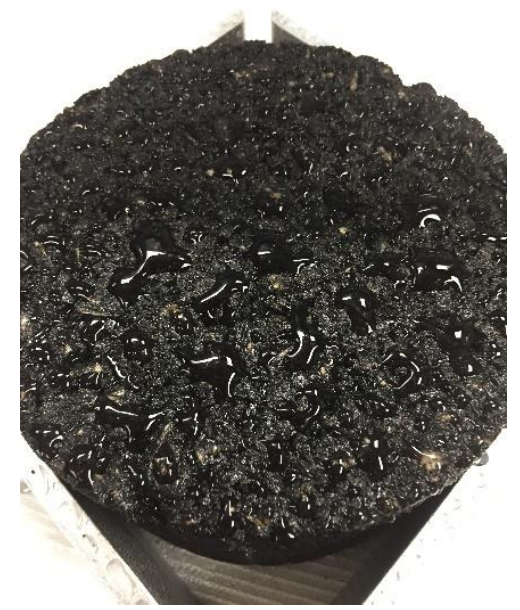

Figure 11: Wetted Specimen Surface for BPT Measurements

Table 14: Amount of Water Used for Specimen Surface Wetting

\begin{tabular}{|c|c|c|c|}
\hline Number of Sprays & $\begin{array}{c}\text { Weight of Water } \\
\text { (g) }\end{array}$ & $\begin{array}{c}\text { Volume of } \\
\text { Water (mL) }\end{array}$ & $\begin{array}{c}\text { Actual Volume } \\
\text { of Water on } \\
\text { Surface (mL) }\end{array}$ \\
\hline 5 & 4.22 & 4.22 & 1.68 \\
\hline 30 & 25.24 & 25.24 & 10.04 \\
\hline
\end{tabular}

- Slider failure occurred at approximately 1,200 BPT swings.

- Randomize specimen measurement order to reduce slider wear bias. 


\section{BPT Field Procedure Notes}

Although not a large portion of the experimental procedure, BPT measurements were also completed in a field environment for laboratory and field comparisons. There is little information in the specification regarding field testing. As such, procedural steps were assumed to parallel laboratory techniques accompanied by additional equipment leveling protocol. Supplementary notes describing the field procedure used in this experiment include:

- Field measurement locations were the fast lane of I-79 in Flatwoods, WV. Additional location details are provided in the Appendix A.

- The BPT was leveled according to each of the five location geometries, Figure 12. Testing locations were chosen based on the corresponding field cored specimens tested in the laboratory. Cored specimens were either extracted from the left or right wheel path. Measurements were recorded in either wheel path (dependent on the core location) and in the center of the lane. Measurements were also recorded in both the uphill and downhill directions due to varying roadway elevations.

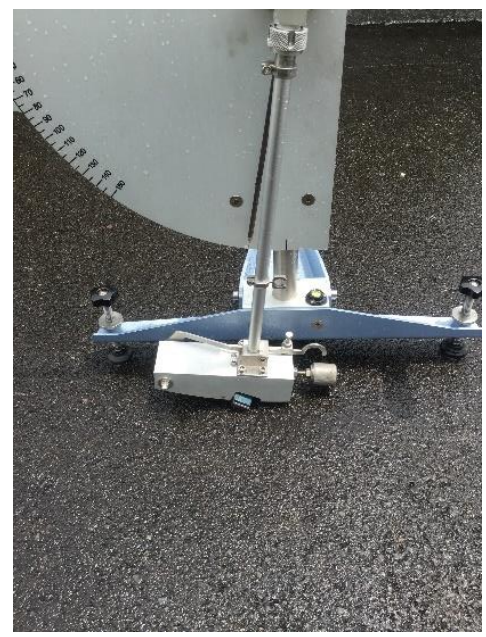

Figure 12: BPT in Field Application

- Surfaces were wetted with the same technique used in the laboratory. However, it should be noted that precipitation began in the middle of the testing period, which could have influenced measurements. Figure 13 depicts the wetted surface in the field. 


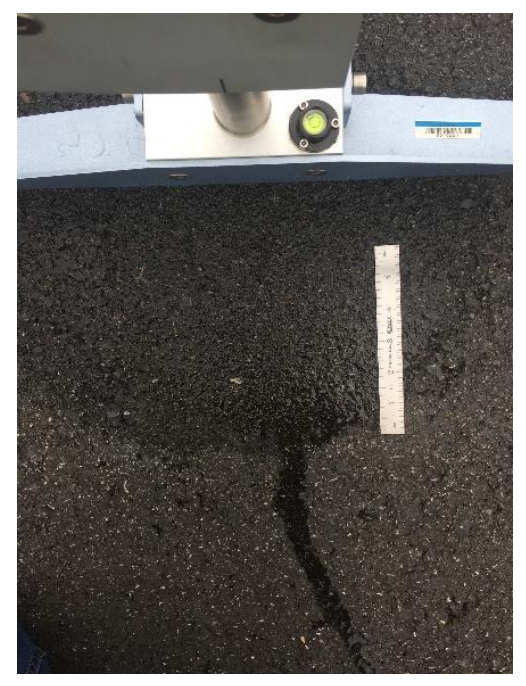

Figure 13: Wetted BPT Surface in Field

\section{British Pendulum Number Analysis}

Average BPN values were calculated for each specimen using the four recorded measurements after each polishing session. These values were plotted versus the number of wheel passes. Average measurements calculated for each set of replicates was averaged a second time to compute a mixture average. There were three replicates for each mixture. Mixture averages were also plotted and used to create trend lines for data fitting. Specimens were polished until plotted measurements displayed the appearance of a plateau. BPN measurements showed asymptotic behavior varying between 48,000 and 80,000 wheel passes.

Various fitting methods were considered including polynomial, logarithmic, and power functions. Power functions were ultimately chosen due to high $\mathrm{R}^{2}$ values and visual observation. This was completed for all mixtures and trials throughout the experiment. The slope was calculated for each trend line by inputting the final number of wheel passes \pm 100 to determine a asymptotic behavior. For example, 47,900 and 48,100 wheel passes were used for trials with a maximum of 48,000 wheel passes. Plots were then replicated and altered to represent the independent and dependent variables as BPN and the number of wheel passes, respectively. This allowed for the prediction of the number of wheel passes $\left(\mathrm{N}_{\mathrm{p}}\right)$ required to achieve two BPN limits: BPN=35 (Kowalski et al., 2013) and BPN=47 (Lu and Steven, 2006). For trials where the number of wheel passes exceeded 48,000, slope and BPN calculations were computed at 48,000 wheel passes and the ending number of wheel passes. 


\section{Statistical Analysis}

BPN measurements were analyzed statistically to determine the significance of variables in the polishing procedure. Data were organized according to various factors and levels. Factors include tire types, tire toe angles, VTM, nominal maximum aggregate size (NMAS), contractor, and environment (lab/field). Factors were broken down into several levels, displayed in Table 15. Table 16 shows the factors and levels and the samples. Various statistical analysis methods were considered for this experiment including t-tests, ANOVA, and regression. These methods were reviewed and discussed in a meeting with a qualified statistician (Pyrialakou, 2020). Based on the layout of the data and the advice from a statistical expert, t-tests were chosen for analyzing BPN data. All t-tests were for two-tail, assumed equal variances, null hypothesis of equal means, and alpha of 0.05 .

Table 15: Experimental Factors and Levels

\begin{tabular}{|c|c|c|c|c|c|c|}
\hline \multirow{2}{*}{} & \multicolumn{6}{|c|}{ Factors } \\
\cline { 2 - 8 } & Tires & Toe Angles & VTM & NMAS & Contractor & Environment \\
\hline \multirow{3}{*}{ Levels } & Burris B55A & Low & $4 \%$ & $9.5 \mathrm{~mm}$ & JFA & Laboratory \\
\cline { 2 - 7 } & Hoosier R80 & High & $8 \%$ & $12.5 \mathrm{~mm}$ & WVP & Field Core \\
\cline { 2 - 7 } & & & & & Greer & Field Measurements \\
\hline
\end{tabular}

The significance of toe angles was determined first by comparing measurements collected from low and high toe angles with Burris B55A tires. This was followed by analyses for all factors using only data collected with Hoosier R80 tires. Additional testing was performed for laboratory and field specimens obtained from J. F. Allen by comparing initial BPN measurements to determine potential differences in friction behaviors. The same samples were compared using BPN data collected after polishing for 48,000 wheel passes. Final t-tests were performed comparing initial BPN measurements of field core specimens to measurements completed in their corresponding locations on Interstate 79 (I-79). All location details and raw data are located in Appendices A and D, respectively. 
Table 16: Testing Parameter Breakdown and Potential Sample Comparisons

\begin{tabular}{|c|c|c|c|c|c|c|}
\hline \multicolumn{7}{|c|}{ Experimental Factors } \\
\hline \multirow{2}{*}{ Toe } & \multirow{2}{*}{ VTM } & \multirow{2}{*}{ NMAS } & \multirow{2}{*}{ Surface } & \multirow{2}{*}{ Contractor } & Burris B55A Tires & Hoosier R80 Tires \\
\hline & & & & & \multicolumn{2}{|c|}{ Specimens } \\
\hline \multirow{24}{*}{ Low } & \multirow{12}{*}{$4 \%$} & \multirow{6}{*}{9.5} & \multirow{3}{*}{ Top } & JFA & & \\
\hline & & & & WVP & $7 \mathrm{~T}, 8 \mathrm{~T}, 9 \mathrm{~T}$ & \\
\hline & & & & Greer & & \\
\hline & & & \multirow{3}{*}{ Bottom } & JFA & & \\
\hline & & & & WVP & & $31 \mathrm{~B}, 32 \mathrm{~B}, 33 \mathrm{~B}$ \\
\hline & & & & Greer & & $16 \mathrm{~B}, 17 \mathrm{~B}, 18 \mathrm{~B}$ \\
\hline & & \multirow{6}{*}{12.5} & \multirow{3}{*}{ Top } & JFA & $4 \mathrm{~T}, 5 \mathrm{~T}, 6 \mathrm{~T}$ & \\
\hline & & & & WVP & & \\
\hline & & & & Greer & & \\
\hline & & & \multirow{3}{*}{ Bottom } & JFA & & $25 \mathrm{~B}, 26 \mathrm{~B}, 27 \mathrm{~B}$ \\
\hline & & & & WVP & & $19 \mathrm{~B}, 20 \mathrm{~B}, 21 \mathrm{~B}$ \\
\hline & & & & Greer & & \\
\hline & \multirow{12}{*}{$8 \%$} & \multirow{6}{*}{9.5} & \multirow{3}{*}{ Top } & JFA & & \\
\hline & & & & WVP & $10 \mathrm{~T}, 11 \mathrm{~T}, 12 \mathrm{~T}$ & \\
\hline & & & & Greer & & \\
\hline & & & \multirow{3}{*}{ Bottom } & JFA & & \\
\hline & & & & WVP & & $34 \mathrm{~B}, 35 \mathrm{~B}, 36 \mathrm{~B}$ \\
\hline & & & & Greer & & $13 \mathrm{~B}, 14 \mathrm{~B}, 15 \mathrm{~B}$ \\
\hline & & \multirow{6}{*}{12.5} & & JFA & $1 \mathrm{~T}, 2 \mathrm{~T}, 3 \mathrm{~T}$ & \\
\hline & & & Top & WVP & & \\
\hline & & & & Greer & & \\
\hline & & & & JFA & & $28 \mathrm{~B}, 29 \mathrm{~B}, 30 \mathrm{~B}$ \\
\hline & & & Bottom & WVP & & $22 \mathrm{~B}, 23 \mathrm{~B}, 24 \mathrm{~B}$ \\
\hline & & & & Greer & & \\
\hline & & & & JFA & & \\
\hline & & & Top & WVP & & $31 \mathrm{~T}, 32 \mathrm{~T}, 33 \mathrm{~T}$ \\
\hline & & 9.5 & & Greer & & $16 \mathrm{~T}, 17 \mathrm{~T}, 18 \mathrm{~T}$ \\
\hline & & 9.3 & & JFA & & \\
\hline & & & Bottom & WVP & $7 \mathrm{~B}, 8 \mathrm{~B}, 9 \mathrm{~B}$ & \\
\hline & $4 \%$ & & & Greer & & \\
\hline & $4 \%$ & & & JFA & & $25 \mathrm{~T}, 26 \mathrm{~T}, 27 \mathrm{~T}$ \\
\hline & & & Top & WVP & & $19 \mathrm{~T}, 20 \mathrm{~T}, 21 \mathrm{~T}$ \\
\hline & & 125 & & Greer & & \\
\hline & & 12.2 & & JFA & $4 \mathrm{~B}, 5 \mathrm{~B}, 6 \mathrm{~B}$ & \\
\hline & & & Bottom & WVP & & \\
\hline High & & & & Greer & & \\
\hline & & & & JFA & & \\
\hline & & & Top & WVP & & $34 \mathrm{~T}, 35 \mathrm{~T}, 36 \mathrm{~T}$ \\
\hline & & 95 & & Greer & & $13 \mathrm{~T}, 14 \mathrm{~T}, 15 \mathrm{~T}$ \\
\hline & & 9.3 & & JFA & & \\
\hline & & & Bottom & WVP & $10 \mathrm{~B}, 11 \mathrm{~B}, 12 \mathrm{~B}$ & \\
\hline & $8 \%$ & & & Greer & & \\
\hline & $8 \%$ & & & JFA & & $28 \mathrm{~T}, 29 \mathrm{~T}, 30 \mathrm{~T}$ \\
\hline & & & Top & WVP & & $22 \mathrm{~T}, 23 \mathrm{~T}, 24 \mathrm{~T}$ \\
\hline & & 125 & & Greer & & \\
\hline & & 12.5 & & JFA & $1 \mathrm{~B}, 2 \mathrm{~B}, 3 \mathrm{~B}$ & \\
\hline & & & Bottom & WVP & & \\
\hline & & & & Greer & & \\
\hline
\end{tabular}




\section{Chapter 4: Results and Discussion}

Mixture and procedure evaluations were completed through BPN trend fitting and statistical methods. Discussed first are friction trend behaviors, followed by a statistical analysis of collected BPN data. All raw data are in Appendix D. Figures and data used for analyses are in Appendices $\mathrm{E}$ and $\mathrm{F}$.

\section{BPN Analysis}

Trend behaviors were analyzed for specimens tested in trials 2 through 9. Figure 14 displays average BPN data for the JFA $12.5 \mathrm{~mm}$ SR specimens at $8 \%$ VTM, polished with Burris B55A tires. A power function trend line equation and corresponding $\mathrm{R}^{2}$ value is provided for the average of the three replicates.

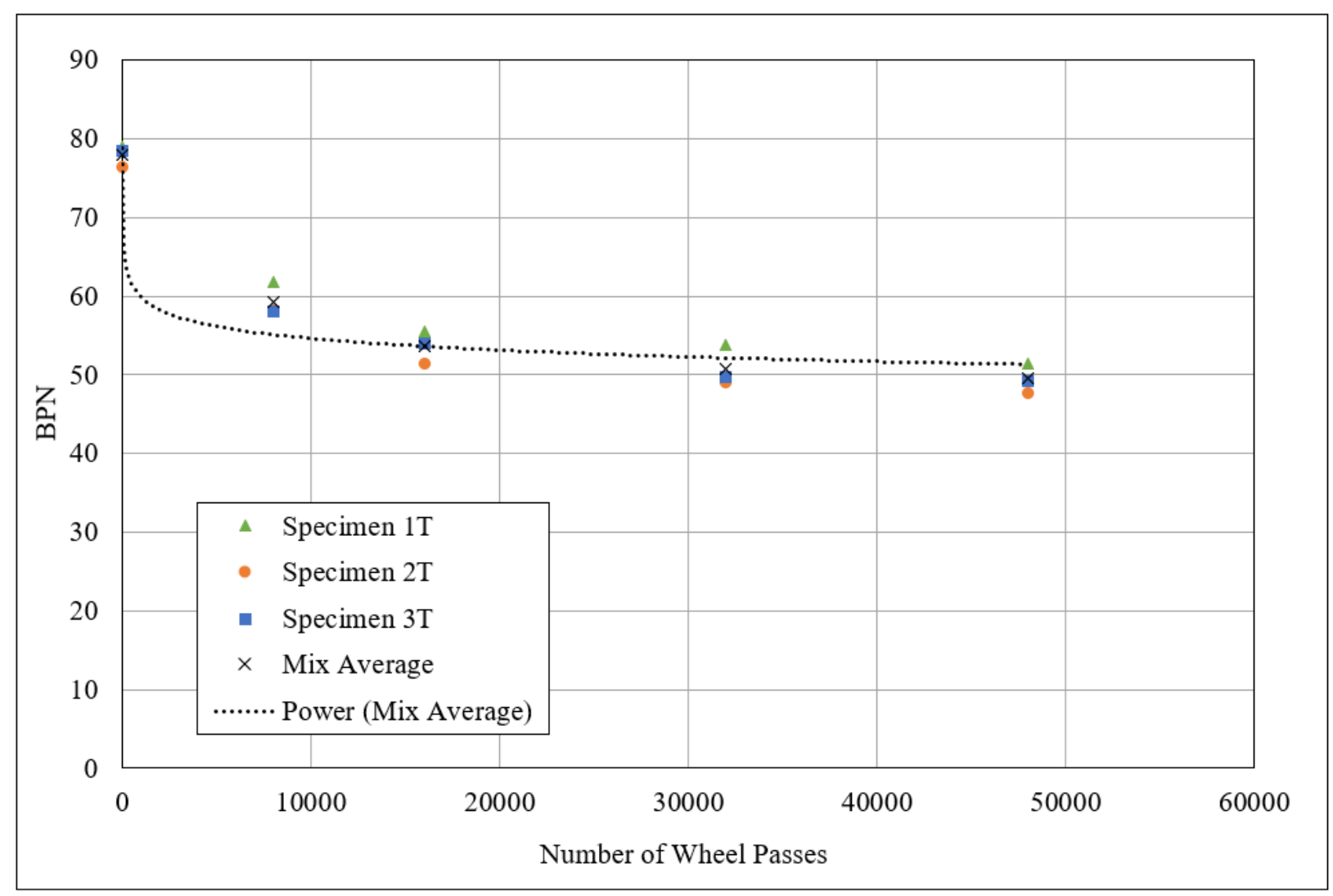

Figure 14: Average BPN Measurements for Trial 2 JFA 12.5mm SR (Top Surfaces) 8\% VTM Specimens After 48,000 Wheel Passes at Low Toe Angles and Burris B55A Tires 
The behavior on Figure 14 is similar to those reported by Vollor and Hanson (2006) and Kowalski et al. (2010) when polishing with the NCAT TWPD. There are minimal changes in slope after approximately 16,000 wheel passes. The slope of the trend line is $4.27 \mathrm{E}-05$, which is close to a slope of zero and appears to visually fit the data. This indicates minimal change in BPN measurements after 48,000 wheel passes, which could provide insight for determining the number of wheel passes required for sufficient laboratory polishing. Slope values and trend line coefficients are summarized in Table 17. 
Table 17: Trend line Coefficients, R2 Values, and Calculated Slopes for General Data and Predicted Number of Wheel Passes at BPN Limits of 35 and 47

\begin{tabular}{|c|c|c|c|c|c|c|c|c|c|c|c|c|c|c|c|}
\hline \multirow[t]{2}{*}{ Trial } & \multirow{2}{*}{$\begin{array}{c}\text { Toe } \\
\text { Angles }\end{array}$} & \multirow[t]{2}{*}{ Tire } & \multirow{2}{*}{\begin{tabular}{|c|} 
Total \\
Wheel \\
Passes \\
\end{tabular}} & \multirow{2}{*}{$\begin{array}{c}\text { Test } \\
\text { Surface }\end{array}$} & \multirow[t]{2}{*}{ Tested Mixture } & \multirow{2}{*}{$\begin{array}{c}\text { Analyzed } \\
\text { Wheel } \\
\text { Passes }\end{array}$} & \multicolumn{2}{|c|}{$\begin{array}{l}\text { Power Coefficients } \\
\qquad y=a x^{b * * *}\end{array}$} & \multirow[t]{2}{*}{$\mathbf{R}^{2}$} & \multirow{2}{*}{$\begin{array}{l}\text { Average } \\
\text { Mix Slope }\end{array}$} & \multicolumn{2}{|c|}{$\begin{array}{c}\text { Power Coefficients } \\
\qquad y=a x^{b * * * *}\end{array}$} & \multirow[t]{2}{*}{$\mathrm{R}^{2}$} & \multicolumn{2}{|c|}{$\begin{array}{c}\text { Predicted Number of } \\
\text { Required Wheel Passes }\left(N_{p}\right)\end{array}$} \\
\hline & & & & & & & a & b & & & a & $\mathbf{b}$ & & $\mathrm{BPN}=35$ & $\mathrm{BPN}=47$ \\
\hline \multirow{4}{*}{2} & \multirow{4}{*}{ Low } & \multirow{4}{*}{ B55A* } & \multirow{4}{*}{48000} & \multirow{4}{*}{ Top } & $\begin{array}{c}\text { JFA } 12.5 \mathrm{~mm} \text { SR } \\
\text { at } 8 \% \mathrm{VTM}\end{array}$ & $48 \mathrm{k}$ & 78.883 & -0.040 & 0.9449 & $4.27 \mathrm{E}-05$ & $1.50 \mathrm{E}+45$ & -23.71 & 0.9449 & $2.46 \mathrm{E}+08$ & $2.26 E+05$ \\
\hline & & & & & \begin{tabular}{|c|} 
JFA $12.5 \mathrm{~mm}$ SR \\
at $4 \%$ VTM
\end{tabular} & $48 \mathrm{k}$ & 81.228 & -0.047 & 0.983 & $4.79 \mathrm{E}-05$ & $3.93 E+39$ & -20.70 & 0.983 & $4.36 \mathrm{E}+07$ & $9.76 E+04$ \\
\hline & & & & & \begin{tabular}{|c|} 
WVP W1-RAP at \\
$8 \%$ VTM \\
\end{tabular} & $48 \mathrm{k}$ & 84.459 & -0.042 & 0.9679 & $4.70 \mathrm{E}-05$ & $7.86 \mathrm{E}+44$ & -23.24 & 0.9679 & $1.04 \mathrm{E}+09$ & $1.11 E+06$ \\
\hline & & & & & \begin{tabular}{|c|} 
WVP W1-RAP at \\
$4 \%$ VTM
\end{tabular} & $48 \mathrm{k}$ & 83.334 & -0.043 & 0.9609 & $4.70 \mathrm{E}-05$ & $3.49 \mathrm{E}+43$ & -22.6 & 0.9609 & $3.81 \mathrm{E}+08$ & $4.87 \mathrm{E}+05$ \\
\hline \multirow{8}{*}{3} & \multirow{8}{*}{ High } & \multirow{8}{*}{ B55A* } & \multirow{8}{*}{80000} & \multirow{8}{*}{ Bottom } & \multirow{2}{*}{$\begin{array}{c}\text { JFA } 12.5 \mathrm{~mm} \text { SR } \\
\text { at } 8 \% \text { VTM }\end{array}$} & $48 \mathrm{k}$ & 70.591 & -0.035 & 0.9835 & $3.53 \mathrm{E}-05$ & $4.54 \mathrm{E}+52$ & -28.45 & 0.9835 & $5.89 \mathrm{E}+08$ & $1.34 \mathrm{E}+05$ \\
\hline & & & & & & $80 \mathrm{k}$ & 70.102 & -0.032 & \begin{tabular}{|l|}
0.9374 \\
\end{tabular} & \begin{tabular}{|l|}
$3.31 E-05$ \\
\end{tabular} & $5.06 \mathrm{E}+53$ & -28.97 & \begin{tabular}{|l|}
0.9374 \\
\end{tabular} & $9.28 \mathrm{E}+08$ & $1.81 \mathrm{E}+05$ \\
\hline & & & & & \multirow{2}{*}{$\begin{array}{c}\text { JFA } 12.5 \mathrm{~mm} \text { SR } \\
\text { at } 4 \% \mathrm{VTM}\end{array}$} & $48 \mathrm{k}$ & 71.27 & -0.037 & 0.9812 & $3.69 \mathrm{E}-05$ & $6.98 \mathrm{E}+49$ & -26.87 & 0.9812 & $2.27 \mathrm{E}+08$ & $8.24 \mathrm{E}+04$ \\
\hline & & & & & & $80 \mathrm{k}$ & 70.714 & -0.034 & 0.9257 & \begin{tabular}{|l|}
$3.47 \mathrm{E}-05$ \\
\end{tabular} & $3.80 \mathrm{E}+50$ & -27.19 & 0.9257 & $4.16 \mathrm{E}+08$ & $1.37 \mathrm{E}+05$ \\
\hline & & & & & \multirow{2}{*}{$\begin{array}{c}\text { WVP W1-RAP at } \\
8 \% \text { VTM }\end{array}$} & $48 \mathrm{k}$ & 75.967 & -0.037 & 0.9709 & $3.93 \mathrm{E}-05$ & $3.16 E+49$ & -26.27 & 0.9709 & $8.21 \mathrm{E}+08$ & $3.56 \mathrm{E}+05$ \\
\hline & & & & & & $80 \mathrm{k}$ & 75.954 & -0.037 & 0.9721 & 3.93E-05 & $3.52 \mathrm{E}+49$ & -26.29 & \begin{tabular}{|l|l|}
0.9721 \\
\end{tabular} & $1.02 \mathrm{E}+09$ & $4.39 \mathrm{E}+05$ \\
\hline & & & & & \multirow{2}{*}{$\begin{array}{c}\text { WVP W1-RAP at } \\
4 \% \text { VTM }\end{array}$} & $48 \mathrm{k}$ & 72.284 & -0.04 & 0.9659 & $4.24 \mathrm{E}-05$ & $1.52 E+46$ & -24.3 & 0.9659 & $6.03 \mathrm{E}+08$ & $4.67 \mathrm{E}+05$ \\
\hline & & & & & & $80 \mathrm{k}$ & 78.232 & -0.039 & 0.9705 & \begin{tabular}{|l|l|}
$4.17 E-05$ \\
\end{tabular} & $4.50 \mathrm{E}+46$ & -24.58 & 0.9705 & $5.57 \mathrm{E}+08$ & $3.97 \mathrm{E}+05$ \\
\hline \multirow{4}{*}{4} & \multirow{4}{*}{ High } & \multirow{4}{*}{ Hoosier** } & \multirow{4}{*}{48000} & \multirow{4}{*}{ Top } & $\begin{array}{l}\text { WVP } 12.5 \mathrm{~mm} \\
\text { SR at } 8 \% \text { VTM }\end{array}$ & $48 \mathrm{k}$ & 86.716 & -0.053 & 0.9694 & $5.41 \mathrm{E}-05$ & $4.53 \mathrm{E}+35$ & -18.34 & 0.9694 & $2.40 \mathrm{E}+07$ & $1.08 \mathrm{E}+05$ \\
\hline & & & & & $\begin{array}{l}\text { WVP } 12.5 \mathrm{~mm} \\
\text { SR at 4\% VTM }\end{array}$ & $48 \mathrm{k}$ & 84.523 & -0.053 & 0.9817 & $5.27 \mathrm{E}-05$ & $9.57 \mathrm{E}+35$ & -18.64 & 0.9817 & $1.65 \mathrm{E}+07$ & $6.79 \mathrm{E}+04$ \\
\hline & & & & & $\begin{array}{c}\text { Greer W1H at } \\
8 \% \text { VTM }\end{array}$ & $48 \mathrm{k}$ & 86.629 & -0.054 & 0.9769 & $5.19 \mathrm{E}-05$ & $4.56 \mathrm{E}+34$ & -18.04 & 0.9769 & $6.98 \mathrm{E}+06$ & $3.42 \mathrm{E}+04$ \\
\hline & & & & & $\begin{array}{c}\text { Greer W1H at } \\
4 \% \text { VTM }\end{array}$ & $48 \mathrm{k}$ & 84.792 & -0.058 & 0.9643 & $5.48 E-05$ & $2.19 \mathrm{E}+32$ & -16.71 & 0.9643 & $3.16 \mathrm{E}+06$ & $2.29 \mathrm{E}+04$ \\
\hline
\end{tabular}

\section{Notes:}

* Burris $\quad * * * \mathrm{BPN}=\mathrm{a}\left(\mathrm{N}_{\mathrm{p}}\right)^{\mathrm{b}}$

$* *$ Hoosier $\quad * * * * \mathrm{~N}_{\mathrm{p}}=\mathrm{a}(\mathrm{BPN})^{\mathrm{b}}$ 


\begin{tabular}{|c|c|c|c|c|c|c|c|c|c|c|c|c|c|c|c|}
\hline \multirow{2}{*}{ Trial } & \multirow{2}{*}{$\begin{array}{c}\text { Toe } \\
\text { Angles }\end{array}$} & \multirow{2}{*}{ Tire } & \multirow{2}{*}{$\begin{array}{c}\text { Total } \\
\text { Wheel } \\
\text { Passes }\end{array}$} & \multirow{2}{*}{$\begin{array}{c}\text { Test } \\
\text { Surface }\end{array}$} & \multirow{2}{*}{ Tested Mixture } & \multirow{2}{*}{$\begin{array}{c}\text { Analyze } \\
\text { d Wheel } \\
\text { Passes }\end{array}$} & \multicolumn{2}{|c|}{$\begin{array}{l}\text { Power Coefficients } \\
\qquad y=a x^{b * * *}\end{array}$} & \multirow{2}{*}{$\mathbf{R}^{2}$} & \multirow{2}{*}{$\begin{array}{c}\text { Average } \\
\text { Mix } \\
\text { Slope }\end{array}$} & \multicolumn{2}{|c|}{$\begin{array}{l}\text { Power Coefficients } \\
\qquad y=a x^{b * * * *}\end{array}$} & \multirow{2}{*}{$\mathbf{R}^{2}$} & \multicolumn{2}{|c|}{$\begin{array}{c}\text { Predicted Number of } \\
\text { Required Wheel Passes }\left(N_{p}\right)\end{array}$} \\
\hline & & & & & & & a & b & & & a & b & & $\mathrm{BPN}=35$ & $\mathrm{BPN}=47$ \\
\hline \multirow{8}{*}{5} & \multirow{8}{*}{ Low } & \multirow{8}{*}{ Hoosier** } & \multirow{8}{*}{64000} & \multirow{8}{*}{ Bottom } & \multirow{2}{*}{$\begin{array}{l}\text { WVP } 12.5 \mathrm{~mm} \\
\text { SR at } 8 \% \text { VTM }\end{array}$} & $48 \mathrm{k}$ & 78.666 & -0.047 & 0.9432 & $4.64 \mathrm{E}-05$ & $1.98 \mathrm{E}+38$ & -20.10 & 0.9432 & $1.84 E+07$ & $4.92 \mathrm{E}+04$ \\
\hline & & & & & & $64 \mathrm{k}$ & 79.406 & -0.05 & 0.9137 & 4.83E-05 & $6.17 E+34$ & -18.14 & 0.9137 & $5.87 \mathrm{E}+06$ & $2.79 \mathrm{E}+04$ \\
\hline & & & & & \multirow{2}{*}{$\begin{array}{l}\text { WVP } 12.5 \mathrm{~mm} \\
\text { SR at } 4 \% \text { VTM } \\
\end{array}$} & $48 \mathrm{k}$ & 78.353 & -0.044 & 0.9502 & $4.47 \mathrm{E}-05$ & $9.12 \mathrm{E}+40$ & -21.53 & 0.9502 & $5.13 \mathrm{E}+07$ & $8.99 \mathrm{E}+04$ \\
\hline & & & & & & $64 \mathrm{k}$ & 79.26 & -0.048 & 0.8957 & $4.72 \mathrm{E}-05$ & $3.76 \mathrm{E}+35$ & -18.53 & 0.8957 & $9.78 \mathrm{E}+06$ & $4.15 \mathrm{E}+04$ \\
\hline & & & & & \multirow{2}{*}{$\begin{array}{c}\text { Greer W1H at } \\
8 \% \text { VTM }\end{array}$} & $48 \mathrm{k}$ & 76.496 & -0.046 & 0.9531 & $4.46 \mathrm{E}-05$ & $6.23 E+38$ & -20.48 & 0.9531 & $1.43 E+07$ & $3.42 \mathrm{E}+04$ \\
\hline & & & & & & $64 \mathrm{k}$ & 77.342 & -0.05 & 0.8931 & $4.70 \mathrm{E}-05$ & $2.15 E+34$ & -17.97 & 0.8931 & $3.58 \mathrm{E}+06$ & $1.79 \mathrm{E}+04$ \\
\hline & & & & & \multirow{2}{*}{$\begin{array}{c}\text { Greer W1H at } \\
4 \% \text { VTM }\end{array}$} & $48 \mathrm{k}$ & 77.02 & -0.047 & 0.9393 & $4.54 \mathrm{E}-05$ & $1.41 \mathrm{E}+38$ & -20.11 & 0.9393 & $8.89 \mathrm{E}+06$ & $2.37 \mathrm{E}+04$ \\
\hline & & & & & & $64 \mathrm{k}$ & 78.119 & -0.052 & 0.8707 & $4.83 \mathrm{E}-05$ & $1.72 \mathrm{E}+32$ & -16.78 & 0.8707 & $2.46 \mathrm{E}+06$ & $1.75 \mathrm{E}+04$ \\
\hline \multirow{4}{*}{6} & \multirow{4}{*}{ Low } & \multirow{4}{*}{ Hoosier** } & \multirow{4}{*}{48000} & \multirow{4}{*}{ Bottom } & $\begin{array}{c}\text { JFA } 12.5 \mathrm{~mm} \text { SR } \\
\text { at } 8 \% \text { VTM } \\
\end{array}$ & $48 \mathrm{k}$ & 76.732 & -0.038 & 0.974 & $4.03 \mathrm{E}-05$ & $1.62 \mathrm{E}+48$ & -25.53 & 0.974 & $7.60 \mathrm{E}+08$ & $4.10 \mathrm{E}+05$ \\
\hline & & & & & $\begin{array}{c}\text { JFA } 12.5 \mathrm{~mm} \text { SR } \\
\text { at } 4 \% \text { VTM } \\
\end{array}$ & $48 \mathrm{k}$ & 77.795 & -0.042 & 0.9662 & 4.33E-05 & $3.15 E+43$ & -22.94 & 0.9662 & $1.14 E+08$ & $1.32 E+05$ \\
\hline & & & & & $\begin{array}{c}\text { WVP W1-RAP } \\
\text { at } 8 \% \text { VTM } \\
\end{array}$ & $48 \mathrm{k}$ & 85.405 & -0.044 & 0.9452 & $4.87 \mathrm{E}-05$ & $4.97 E+41$ & -21.49 & 0.9452 & $3.29 \mathrm{E}+08$ & $5.83 \mathrm{E}+05$ \\
\hline & & & & & $\begin{array}{c}\text { WVP W1-RAP } \\
\text { at 4\% VTM } \\
\end{array}$ & $48 \mathrm{k}$ & 86.397 & -0.046 & 0.9501 & $5.04 \mathrm{E}-05$ & $1.04 \mathrm{E}+40$ & -20.57 & 0.9501 & $1.73 E+08$ & $4.03 \mathrm{E}+05$ \\
\hline \multirow{4}{*}{7} & \multirow{4}{*}{ High } & \multirow{4}{*}{ Hoosier** } & \multirow{4}{*}{48000} & & $\begin{array}{c}\text { JFA } 12.5 \mathrm{~mm} \text { SR } \\
\text { at } 8 \% \text { VTM } \\
\end{array}$ & $48 \mathrm{k}$ & 76.37 & -0.054 & 0.9218 & $4.80 \mathrm{E}-05$ & $2.55 E+32$ & -17.07 & 0.9218 & $1.32 \mathrm{E}+06$ & $8.60 \mathrm{E}+03$ \\
\hline & & & & & $\begin{array}{c}\text { JFA } 12.5 \mathrm{~mm} \text { SR } \\
\text { at } 4 \% \text { VTM }\end{array}$ & $48 \mathrm{k}$ & 75.42 & -0.053 & 0.9117 & $4.70 \mathrm{E}-05$ & $5.29 \mathrm{E}+32$ & -17.27 & 0.9117 & $1.08 E+06$ & $6.64 \mathrm{E}+03$ \\
\hline & & & & $10 \mathrm{p}$ & \begin{tabular}{|c|} 
WVP W1-RAP \\
at $8 \%$ VTM \\
\end{tabular} & $48 \mathrm{k}$ & 83.173 & -0.059 & 0.9025 & $5.41 \mathrm{E}-05$ & $5.97 E+29$ & -15.33 & 0.9025 & $1.28 E+06$ & $1.40 \mathrm{E}+04$ \\
\hline & & & & & $\begin{array}{l}\text { WVP W1-RAP } \\
\text { at } 4 \% \text { VTM }\end{array}$ & $48 \mathrm{k}$ & 80.715 & -0.055 & 0.8709 & $5.11 \mathrm{E}-05$ & $2.47 \mathrm{E}+30$ & -15.7 & 0.8709 & $1.15 E+06$ & $1.12 E+04$ \\
\hline 8 & High & Hoosier** & 48000 & $\mathbf{N} / \mathbf{A}$ & $\begin{array}{l}\text { JFA } 12.5 \mathrm{~mm} \text { SR } \\
\text { Lab Compacted }\end{array}$ & $48 \mathrm{k}$ & 59.736 & -0.03 & 0.9742 & $2.70 \mathrm{E}-05$ & $1.15 E+58$ & -32.64 & 0.9742 & $4.00 \mathrm{E}+07$ & $2.65 \mathrm{E}+03$ \\
\hline 0 & & & | 70000 & $10 / \mathbf{A}$ & \begin{tabular}{|c|} 
JFA $12.5 \mathrm{~mm}$ SR \\
Field Core
\end{tabular} & $48 \mathrm{k}$ & 62.892 & -0.035 & 0.9943 & 3.14E-05 & $1.96 \mathrm{E}+51$ & -28.51 & 0.9943 & $1.90 \mathrm{E}+07$ & $4.26 \mathrm{E}+03$ \\
\hline 9 & High & Hoosier** & 48000 & N/A & $\begin{array}{c}\text { JFA } 12.5 \mathrm{~mm} \text { SR } \\
\text { Field Core }\end{array}$ & $48 \mathrm{k}$ & 52.53 & -0.017 & 0.6879 & $1.55 \mathrm{E}-05$ & $7.12 \mathrm{E}+71$ & -41.18 & 0.6879 & $1.82 \mathrm{E}+08$ & $9.73 E+02$ \\
\hline
\end{tabular}

Notes:

* Burris $\quad * * * B P N=a\left(N_{p}\right)^{b}$

$* *$ Hoosier $\quad * * * * \mathrm{~N}_{\mathrm{p}}=\mathrm{a}(\mathrm{BPN})^{\mathrm{b}}$ 
Figure 14 shows the conventional way to show polishing data. The trend line equation from this figure can be used to predict the BPN for certain number of wheel applications. For evaluating a mix for skid resistance suitability, a relationship for using BPN limit criteria to compute the number of applications is needed. This relationship is shown on Figure 15.

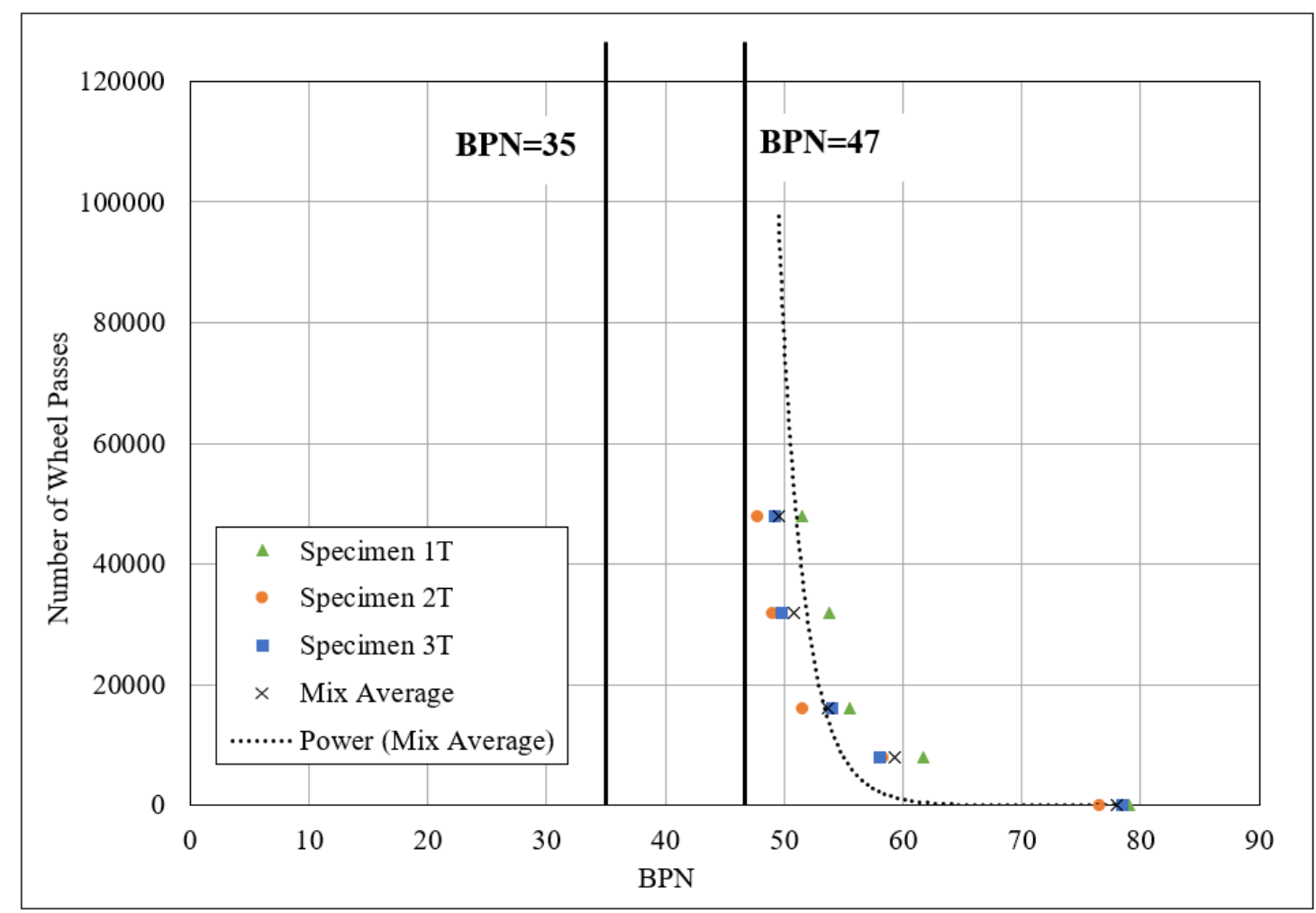

Figure 15: Number of Wheel Passes vs. Average BPN Measurements for Trial 2 JFA 12.5mm SR (Top Surfaces) at 8\% VTM Specimens at Low Toe Angles and Burris B55A Tire

For JFA 12.5mm SR specimens 1T through 3T, the number of wheel passes required to reach BPN values of 35 and 47 were calculated to be 2.46E08 and 226,235 passes, respectively. While 2.46E08 passes is significantly larger than those reported in literature, this value was extrapolated from the data, rather than interpolated. Extrapolation can produce inaccurate results in some applications. Additionally, a BPN of 35 was reported by Kowalski et al. (2010) as the BPN limit for roadways intended for $30 \mathrm{mph}$ speeds, which may not be applicable for a majority of roadways. Evaluating at a BPN of 47 produced a more reasonable result, which is more consistent to values reported by Vollor and Hanson (2006) and Kowalski et al. (2010). Therefore, further discussions of results are in reference to those calculated for a BPN limit of 47. Figure 16 shows the predicted number of wheel passes for all mixtures to reach a BPN of 47. 
Figure 17 shows the predicted number of wheel passes at BPN=47 for JFA $12.5 \mathrm{~mm}$ Skid-RAP lab and field core specimens.

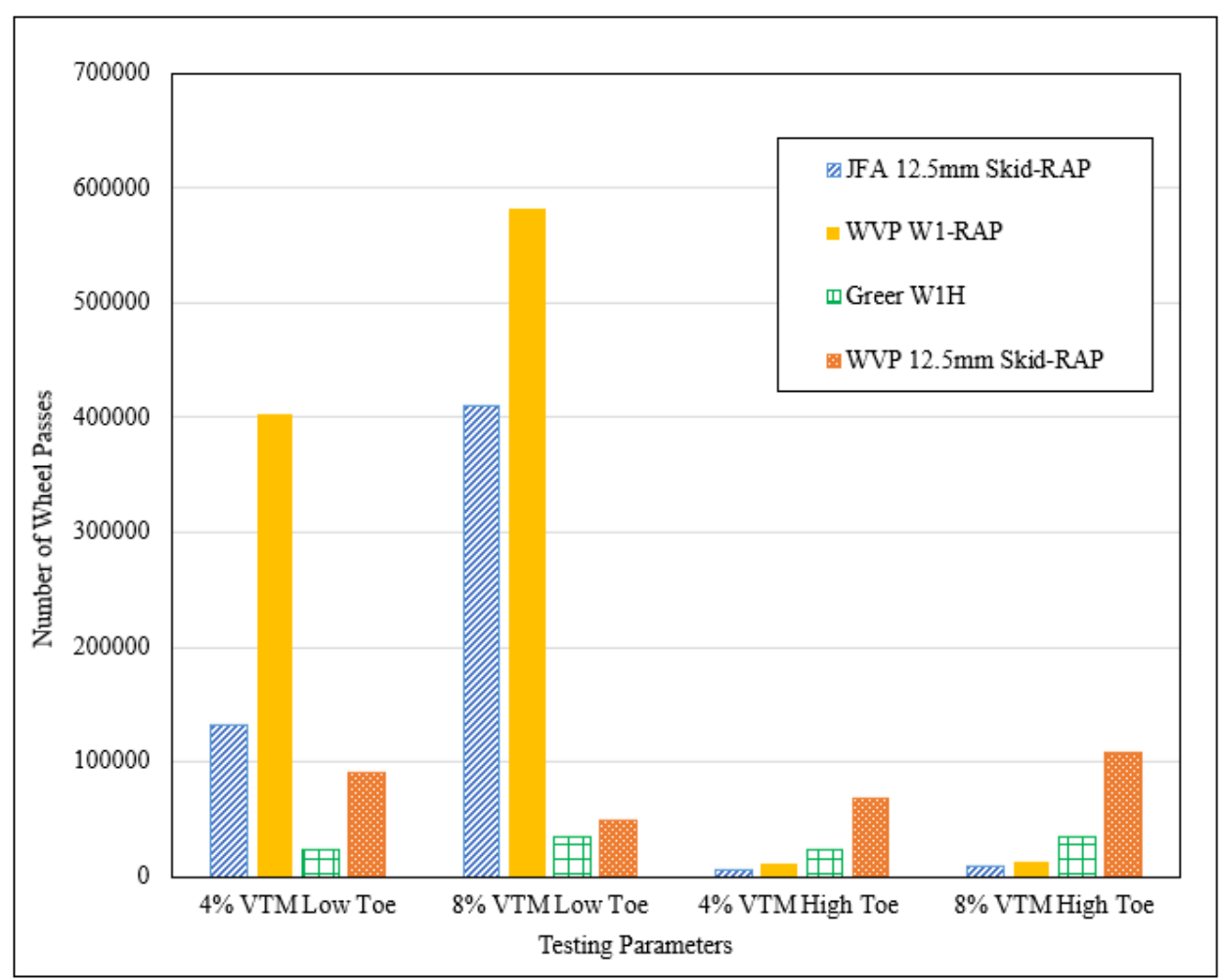

Figure 16: Predicted Number of Wheel Passes to Achieve BPN of 47 for All Mixtures

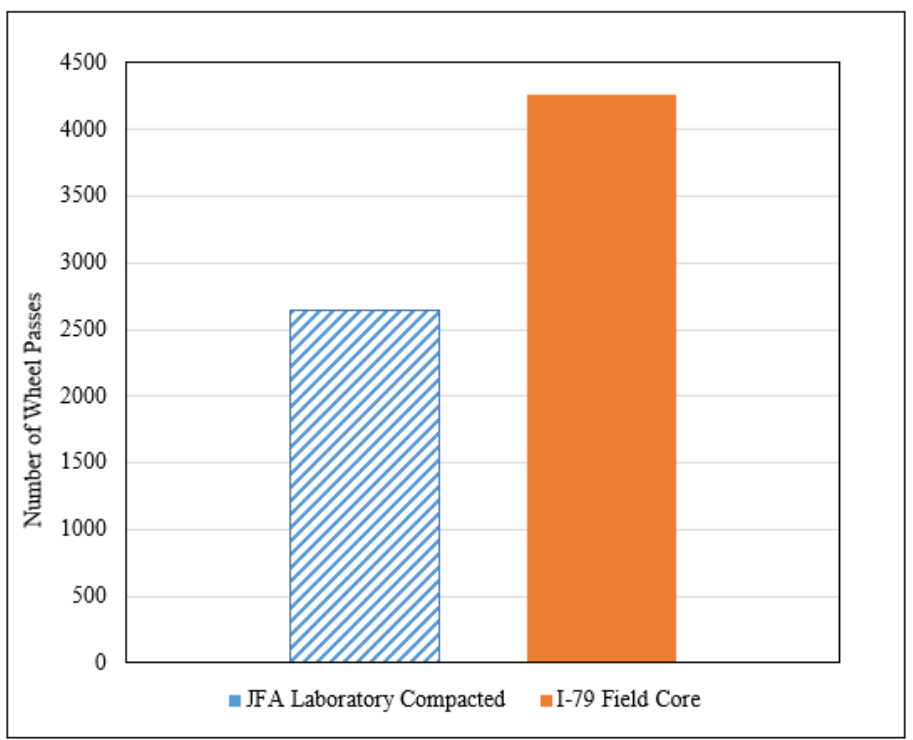

Figure 17: Predicted Number of Wheel Passes at BPN of 47 for JFA 12.5mm Skid-RAP Laboratory and Field Core Specimens 
The projected number of wheel passes at various friction limits can also be used to evaluate asphalt mixtures in the experiment. An increased number of wheel passes represents a more polish resistant mixture, which could provide insight for asphalt mixture design. From Table 17 and Figure 16, it can be seen that the WVP W1-RAP mixture at 8\% VTM in trial 2 resulted in the largest projected number of wheel passes (1.11E06 wheel passes). The five samples with the greatest number of wheel passes were the WVP W1-RAP mixture, suggesting the WVP W1-RAP mixture is more polish resistant than other tested mixtures. Additionally, the majority of mixtures with the largest calculated number of wheel passes were prepared at $8 \%$ VTM. This result could indicate that the increased surface texture allows for excess water storage, producing higher friction measurements.

The lowest calculated number of wheel passes resulted from trial 9 JFA $12.5 \mathrm{~mm}$ SR field core specimens (973 passes). This is significantly lower than the number of passes calculated for WVP W1-RAP specimens, which resulted in the highest calculated values. Lower values could be an indication of differences in compaction for field and laboratory samples. However, additional testing is required to determine a cause. JFA $12.5 \mathrm{~mm}$ SR specimens represent five of the lowest resulting number of wheel passes, which could suggest that this mixture is the least polish resistant of those tested in this experiment. Figure 16 also shows a generally lower number of wheel passes for trials using high toe angles with Hoosier R80 tires, revealing a potential increase in polishing by implementing higher toe angles.

For trials 3 and 5, wheel pass predictions were also performed using data up to the maximum number of wheel passes $(80,000$ and 64,000). The majority of these predictions were higher than values computed using data for 48,000 wheel passes. This could indicate that additional data are useful when predicting the number of wheel passes required to achieve BPN limits. Additional testing is needed to determine the value of increased polishing.

When looking at fitted trend equations, some trials have $\mathrm{R}^{2}$ values less than 0.9 . Low $\mathrm{R}^{2}$ values could indicate that a more complex function is required to properly fit asphalt friction behavior. This is observed visually on Figures 54, 58, 73-76, 81, and 82 in Appendix E. Inadequate fitting functions could have caused unexpected polishing predictions. Predictions of 80,000 passes are not reasonable based on literature (Vollor and Hanson, 2006 and Kowalski et al., 2010) and laboratory observations. Predictions greater than or equal to approximately 
400,000 passes is more consistent with values mentioned in literature. Further research is required to develop a more complete conclusion. The BPN figures are in Appendix E.

\section{Statistical Analysis}

Table 18 provides a summary of t-test results including the mean, variance, degrees of freedom, and p-values for the tested factors. All raw data and outputs used for the analysis are included in Appendix F. Figure 18 shows comparisons of all parameters and standard errors in the t-test analysis. Toe angles were evaluated for Burris B55A tires using measurements collected from JFA $12.5 \mathrm{~mm}$ SR and WVP W1-RAP mixtures. The resulting p-value when comparing BPN measurements from low and high toe angles for Burris B55A tires is 0.09645. This results in a failure to reject the null hypothesis of equal means, indicating measurements are statistically similar. Because the influence of toe angles for Burris B55A data was insignificant, toe angles remained in the analysis when analyzing data using Hoosier R80 tires. Remaining analyses were performed only on data using Hoosier R80 tires.

Table 18: Summary of T-test Results

\begin{tabular}{|c|c|c|c|c|c|c|c|}
\hline Tire Data Used & Analyzed Factor & Compared Variables & Mean & Variance & df & P-Value & Decision \\
\hline \multirow{2}{*}{ Burris B55A } & \multirow{2}{*}{ Toe Angles } & Low Toe & 50.0 & 7.05 & \multirow{2}{*}{22} & \multirow{2}{*}{0.09645} & \multirow{2}{*}{$\mathrm{F}^{*}$} \\
\hline & & High Toe & 48.5 & 1.90 & & & \\
\hline \multirow{2}{*}{ Hoosier R80 } & \multirow{2}{*}{ VTM } & $4 \% \mathrm{VTM}$ & 44.7 & 11.0 & \multirow{2}{*}{46} & \multirow{2}{*}{0.8561} & \multirow{2}{*}{$\mathrm{F}$} \\
\hline & & $8 \% \mathrm{VTM}$ & 44.9 & 11.6 & & & \\
\hline \multirow{2}{*}{ Hoosier R80 } & \multirow{2}{*}{ Toe Angles } & Low Toe & 46.7 & 8.7 & \multirow{2}{*}{46} & \multirow{2}{*}{$3.34 \mathrm{E}-05$} & \multirow{2}{*}{$\mathrm{R}^{* *}$} \\
\hline & & High Toe & 43.0 & 6.8 & & & \\
\hline \multirow{4}{*}{ Hoosier R80 } & \multirow{4}{*}{ Contractor } & JFA & 44.6 & 17.7 & \multirow{2}{*}{22} & \multirow{2}{*}{0.3337} & \multirow{2}{*}{$\mathrm{F}$} \\
\hline & & WVP & 45.9 & 2.1 & & & \\
\hline & & Greer & 43.4 & 0.5 & \multirow{2}{*}{22} & \multirow{2}{*}{0.1593} & \multirow{2}{*}{$\mathrm{F}$} \\
\hline & & WVP & 45.4 & 23.1 & & & \\
\hline \multirow{2}{*}{ Hoosier R80 } & \multirow{2}{*}{ NMAS } & $9.5 \mathrm{~mm}$ & 44.4 & 12.4 & \multirow{2}{*}{46} & \multirow{2}{*}{0.3741} & \multirow{2}{*}{$\mathrm{F}$} \\
\hline & & $12.5 \mathrm{~mm}$ & 45.3 & 9.9 & & & \\
\hline \multirow{4}{*}{ Hoosier R80 } & \multirow{4}{*}{ Sample Type } & Initial Laboratory & 59.4 & 20.8 & \multirow{2}{*}{10} & \multirow{2}{*}{0.4035} & \multirow[t]{2}{*}{$\mathrm{F}$} \\
\hline & & Initial Field Core & 62.8 & 66.8 & & & \\
\hline & & Polished Laboratory & 42.3 & 0.8 & \multirow{2}{*}{10} & \multirow{2}{*}{0.1116} & \multirow{2}{*}{$\mathrm{F}$} \\
\hline & & Polished Field Core & 43.0 & 0.4 & & & \\
\hline Honsier R 80 & Measurement Tyne & Field Core & 51.9 & 17.3 & 8 & 00003 & $R$ \\
\hline Hoosier K80 & Measurement rype & Field Measurement & 74.3 & 53.0 & 8 & 0.0003 & K \\
\hline
\end{tabular}

\section{Notes:}

$* \mathrm{~F}=$ Fail to reject null

** $\mathrm{R}=$ Reject null 


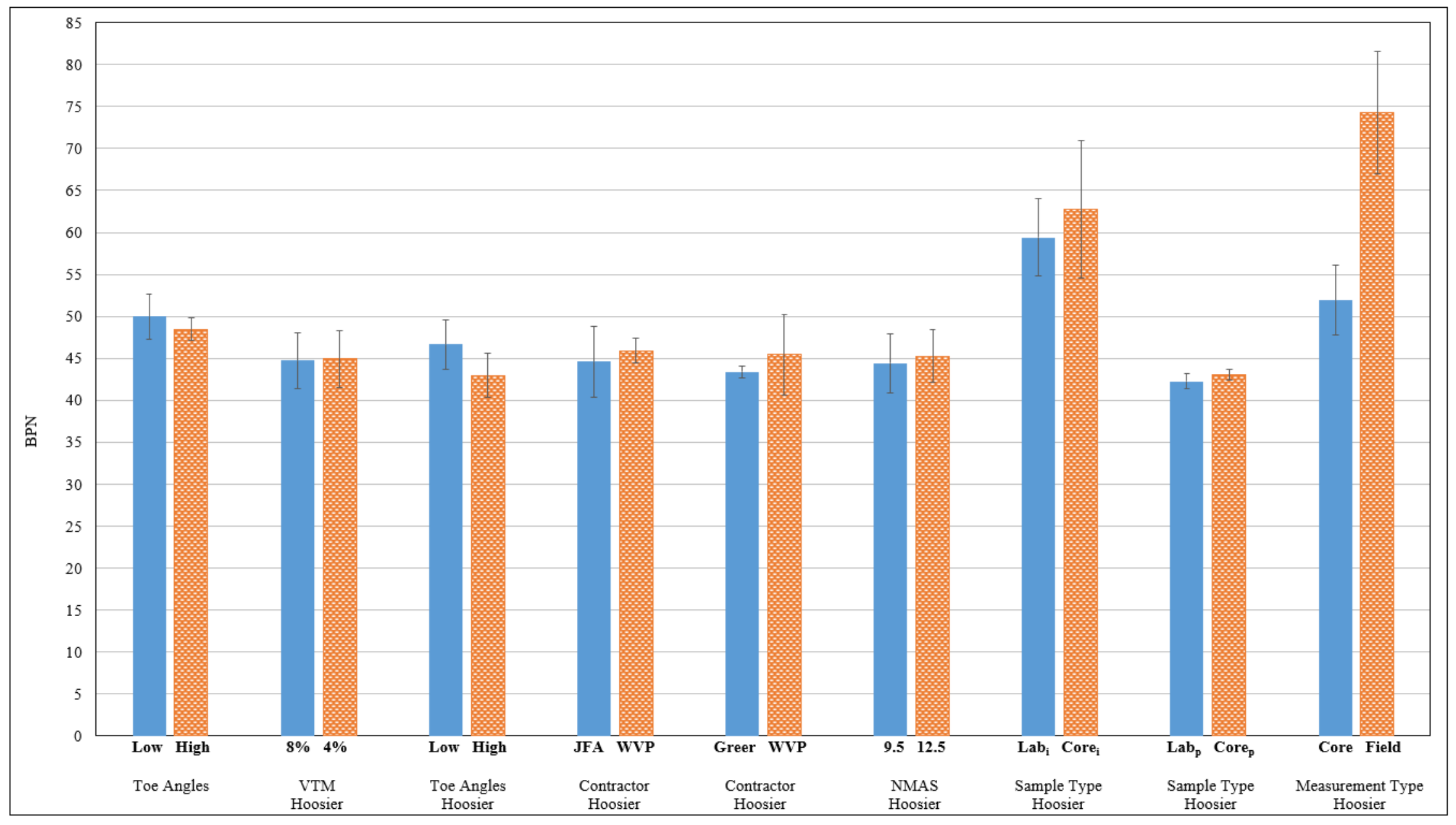

Figure 18: Average BPN Comparison for Tested Parameters 
VTM comparisons for data collected using mixtures with only Hoosier R80 tires report similar results. A p-value of 0.8561 indicates a failure to reject the null hypothesis of equal means, or no significant difference between BPN measurements for all mixtures. However, it can be seen from Table 18 that variances for $4 \%$ and $8 \%$ VTM were 11.0 and 11.6, respectively. High variances may be explained by the lack of direct factor comparisons isolating VTM.

When comparing low and high toe angles for measurements using Hoosier R80 tires, the resulting p-value is 3.342E-05. This results in a rejection of the null hypothesis of equal means, which suggests statistical difference between BPN measurements. This contradicts the previous toe angle analysis using Burris B55A tires. While resulting variances are high, increased toe angles reported a lower variance of 6.81 when compared to the lower toe angle variance of 8.71. This could suggest that higher toe angles produce more consistent polishing and should be used for future testing. When analyzing mean values, the mean BPN value of 42.9 for higher toe angles is several points lower than the mean value of 46.7 reported for lower toe angles. This suggests that there is an increase in the polishing for specimens exposed to higher toe angles, which decreases the testing time required in the laboratory.

Insignificant results were reported when comparing data collected from JFA and WVP 12.5mm SR mixtures to determine the influence of contractor on measured BPN values. The resulting p-value is 0.3337 , failing to reject the null hypothesis of equal means. However, it is important to note that specimens compacted with the JFA mixture resulted in a variance of 17.7 when compared to WVP specimens with a variance of 2.1. Large variances could be explained by the use of data from both toe angles in the analysis, which reported significant differences between BPN measurements previously using data from Hoosier R80 tires.

Similar results are reported when comparing Greer and WVP contractors for the $9.5 \mathrm{~mm}$ mixtures. A p-value of 0.1593 suggests no significant difference and a failure to reject the null hypothesis of equal means. For this analysis, specimens compacted using the Greer mixture reported a low variance of 0.5 , while data from WVP mixtures resulted in a high variance of 23.1. Low variances using the Greer mixtures suggests that this is a relatively consistent mixture in terms of measured friction values. Data collected from both toe angles were included in the analysis, which could contribute to higher resulting variances. 
Analysis performed investigating the influence of NMAS on measured friction values reported insignificant results. When comparing all $9.5 \mathrm{~mm}$ and $12.5 \mathrm{~mm}$ mixtures, the resulting $\mathrm{p}$ value is 0.3741, suggesting no significant difference between mean BPN measurements and a failure to reject the null hypothesis. Higher variance is reported for data collected from $9.5 \mathrm{~mm}$ specimens when compared to the variance reported from $12.5 \mathrm{~mm}$ specimens, which were 12.4 and 9.9, respectively. However, there are difficulties in determining a cause for high variances and distinct conclusion in terms of significance due to the lack in direct factor comparisons present in the analysis. Additional testing is required to determine more concise results.

Final t-tests were completed for JFA $12.5 \mathrm{~mm}$ SR field and laboratory data. Data was first compared using initial BPN measurements collected from matching laboratory and field core specimens. Comparing initial BPN measurements resulted in a p-value of 0.4305 , indicating a failure to reject the null hypothesis of equal means. This suggests that there is no significance between the laboratory and field samples. However, it should be noted that reported variances are 20.8 and 66.8 for laboratory and field core specimens, respectively. These values are extremely large and could potentially be due to differences in compaction. After polishing for 48,000 wheel passes, the collected measurements were analyzed again, producing a p-value of 0.1116. This also suggests that there is no significant difference between the paired laboratory and field specimens. Reported variances were also less than one, suggesting consistency between measurements.

Measurements were also collected from extracted field core specimens and matching field locations on I-79 in Flatwoods, WV. Table 19 displays differences between average initial field core measurements and corresponding field measurements. For this comparison, the resulting p-value is 0.0003 . Because the p-value is less than 0.05 , the null hypothesis of equal means is rejected, suggesting a statistical difference between BPN measurements. Variances are also high for field core and field measurements with values of 17.3 and 53.0, respectively. These differences are evident in Table 19 when comparing laboratory and field measurements. Large differences could be explained by varying compaction procedures and difficulties setting up equipment in the field. However, additional testing is required to further analyze potential differences between laboratory and field friction measurements due to inadequate sample sizes. 
Table 19: Differences in BPN Measurements for Corresponding I-79 JFA 12.5mm SR Field Core and Field Measurements

\begin{tabular}{|c|c|c|c|}
\hline Specimen & $\begin{array}{c}\text { Average Lab Initial } \\
\text { BPN }\end{array}$ & $\begin{array}{c}\text { Average Field } \\
\text { BPN }\end{array}$ & Difference \\
\hline D1 & 59.0 & 74.5 & 15.5 \\
\hline D2 & 48.0 & 69.9 & 21.9 \\
\hline D3 & 50.5 & 67.4 & 16.9 \\
\hline D4 & 50.8 & 73.5 & 22.8 \\
\hline D5 & 51.3 & 86.3 & 35.1 \\
\hline
\end{tabular}




\section{Chapter 5: Conclusions and Recommendations}

\section{Significance of Work}

Prior to this thesis experiment, the WVDOH did not employ an accelerated laboratory polishing machine in asphalt pavement evaluation practices. This thesis provides descriptions of best practices in polishing procedures and laboratory friction measuring techniques for continued use within the agency. Data collected from this experiment contributes to information regarding asphalt pavement performance. Findings from this research also provide insight into factors influencing pavement polishing resistance. Results from this experiment and those completed in the future will assist the WVDOH in providing increased safety for the public.

\section{Conclusions}

\section{BPN Analysis}

The majority of friction behaviors for laboratory compacted specimens was consistent throughout the experiment. BPN measurements decreased as polishing increased. Friction values displayed asymptotic behavior for most specimens and testing periods. Fitting this behavior with power functions allowed for predictions of the number of wheel passes required to achieve BPN limits of 35 and 47. Mixtures with the greatest number of calculated wheel passes at given BPN limits were deemed more polish resistant. For calculations at $\mathrm{BPN}=47, \mathrm{~W} 1-\mathrm{RAP}$ at $8 \% \mathrm{VTM}$ had the highest prediction (1.11E06 wheel passes). The WVP W1-RAP mixture made up the majority of predictions with the largest number of wheel passes, suggesting that this is the most polish resistant mixture. The JFA $12.5 \mathrm{~mm}$ SR field core data in trial 9 displayed the least polish resistant behavior. Five of the lowest computed wheel passes resulted from the JFA $12.5 \mathrm{~mm}$ SR mixture.

Most JFA 12.5mm SR field core specimens reported increased friction values compared to laboratory samples. These measurements could be due to differences in field compaction. However, limited specimens were available for performing comparisons. Additional comparisons completed on field core and field measurement pairs produced mixed results. When 
compared to field measurements performed in the same locations, large differences in values were computed. This could be due to variability in BPT procedures in the field.

\section{Statistical Analysis}

Statistical analysis procedures were performed on average BPN data to determine the influence of different variables on specimen polishing resistance. A t-test comparing low and high toe angles using Burris B55A tires resulted in a p-value of 0.09645, which suggests that there is no significant difference between mean BPN measurements. However, this tire type is no longer available. Analysis completed for all data using Hoosier R80 tires suggests that toe angles are a significant influence on friction behavior. This was the only factor suggesting significant difference for data using Hoosier R80 tires. T-test outputs indicate the mean friction value reported after polishing with high toe angles is lower than the mean for data at lower toe angles. This suggests increased polishing when using higher toe angles, which could decrease the time needed for testing. Comparisons between VTM, contractor, and NMAS did not result in any statistically significant results. Resulting p-values were 0.8561, 0.3337, 0.1593, and 0.3741, respectively. P-values result in a failure to reject the null hypothesis, suggesting no significant influence from differences in VTM, contractor, or NMAS.

When comparing initial BPN measurements for JFA $12.5 \mathrm{~mm}$ SR field core and laboratory compacted specimens, a p-value of 0.4305 was reported, suggesting no significant difference. A similar result is reported when comparing the same specimens after polishing for 48,000 wheel passes. This comparison resulted in a p-value of 0.1116 , which again results in a failure to reject the null hypothesis of equal means. Comparisons between JFA $12.5 \mathrm{~mm}$ SR field core specimens and corresponding field locations on I-79 suggest there is a statistical difference between friction values. This result is consistent with the differences calculated in Table 18 . Differences in measurements could be a result of difficulties leveling the equipment and compaction variabilities in the field.

It is important to note that sample sizes were limited for a reliable statistical analysis, specifically for field data. Inadequate sample sizes could introduce bias in the results. There were limited comparisons available for the majority of t-tests, which could have skewed the results. A limited sample size is also the cause of higher reported variances, which minimizes the reliability 
of the results. Because of these implications, a majority of the results could be considered inconclusive. Further testing is needed to address sample size and variance issues and provide better observations.

\section{Recommendations}

In terms of equipment, Hoosier R80 tires are recommended for future testing because they appear to provide adequate sample surface polishing and maintain their integrity for extended testing durations. Following the completion of statistical analysis, VTM had no significant influence on BPN measurements. Because of this, it is recommended that specimens are compacted at a VTM most similar to those achieved in field applications (approximately $7 \%$. Additionally, mean friction values reported for higher toe angles were significantly lower than lower toe angles. Higher toe angles are recommended to accelerate the polishing process. Similarly, less frequent friction measurements are suggested to further decrease testing durations. For this experiment, 48,000 wheel passes in the polishing machine was deemed sufficient to reach a stopping point for measurements. Additional testing could also be performed to determine the significance of abrasive on the polishing process. The procedure for applying the silicon carbide abrasive remained constant; specimens were not tested without the use of abrasive. Further analysis is recommended to determine the influence of abrasive.

Testing is also needed to determine the influence of sample testing surface (top and bottom) on average friction measurements. This could provide insight for investing potential influences of laboratory compaction on friction measurements. Additionally, mixtures were limited to three contractors and two aggregate sizes. NMAS values of $9.5 \mathrm{~mm}$ and $12.5 \mathrm{~mm}$ mixtures were specific to Marshall and Superpave designs, respectively. Skid and non-skid mixtures were also specific to Marshall and Superpave designs. Alternate mixture designs for these sizes and $4.75 \mathrm{~mm}$ mixtures are recommended for future testing. Mixtures with varying skid and non-skid designations should also be tested to increase data collection and provide further insight on the polishing behavior of various mixtures.

This experiment also lacked data comparing field and laboratory measurements. The sample size for comparisons was limited to six laboratory-compacted and field extracted specimen pairs and five field core specimens and field measurement pairs. This is an inadequate 
sample size for proper statistical analysis. Further investigation of field and laboratory friction behaviors is recommended. Upgrading the testing equipment could also provide more insight for developing laboratory and field relationships. Skid resistance becomes a more sensitive issue as vehicles travel at higher speeds. The BPT measures friction a low speeds, which could explain ttest results reporting no significant differences for various factors in the analysis. The DFT is a state-of-the-art friction measuring apparatus that allows for testing at higher speeds (Hall et al., 2009). Upgrading to this equipment would allow for more meaningful comparisons between laboratory and field friction behaviors in the future. 


\section{References}

Asi, I. M. 2005. "Evaluating skid resistance of different asphalt concrete mixes." Building and Environment. Vol. 42(1), pp. 325-329. https://doi.org/10.1016/j.buildenv.2005.08.020 (accessed July 27, 2019).

ASTM International. Standard Test Method for Skid Resistance of Paved Surfaces Using a FullScale Tire. ASTM E274/E274M-15. West Conshohocken, PA: ASTM International, 2015.

Corley-Lay, J.B. 1998. "Friction and Surface Texture Characterization of 14 Pavement Test Sections in Greenville, North Carolina." Journal of the Transportation Research Board, Vol. 1639(1), pp. 155-161. https://doi.org/10.3141\%2F1639-17 (accessed May 19).

Do, M. T., and M. Kane, and V. Cerezo. 2013. "Laboratory test methods for polishing asphalt surfaces and predicting their skid resistance." Presented at Transportation Research Board 92nd Annual Meeting. France. https://hal.archives-ouvertes.fr/hal-00851150 (accessed May 26, 2019).

Do, M. T., and Z. Tang, and Malal Kane, and Francois de Larrard. 2007. "Pavement polishing Development of a dedicated laboratory test and its correlation with road results." Wear. Vol. 263(1-6), pp. 36-42. https://doi.org/10.1016/j.wear.2006.12.086 (accessed May 26, 2019).

Erukulla, S. 2011. "Refining a Laboratory Procedure to Characterize Change in Hot-Mix Asphalt Surface Friction.” MS Thesis. Auburn University.

Federal Highway Administration Research and Technology. 2015. Evaluation of Pavement Safety Performance. FHWA-HRT-14-065. https://www.fhwa.dot.gov/publications/research/safety/14065/002.cfm (accessed May 11, 2019).

Federal Highway Administration. 2016. "Pavement Friction.” FHWA. https://safety.fhwa.dot.gov/roadway_dept/pavement_friction/(accessed May 9, 2019).

Friel, S., and M. Kane, and D. Woodward. 2013. "Use of Wehner Schulze to predict skid resistance of Irish surfacing materials.” Presented at 2013 Airfield \& Highway Pavement Conference. France.

https://www.researchgate.net/publication/269046624_Use_of_Wehner_Schulze_to_Predi ct_Skid_Resistance_of_Irish_Surfacing_Materials (accessed May 26, 2019).

Gandhi, P. M., B. Colucci, and S. P. Gandhi. 1991. "Polishing of Aggregates and Wet-Weather Accident Rates for Flexible Pavements." Journal of the Transportation Research Board, (1300), pp. 71-79. http://onlinepubs.trb.org/Onlinepubs/trr/1991/1300/1300-009.pdf (accessed May 11, 2019).

Greer, M. and M. Heitzman. 2017. Evaluation of the AIMS2 and Micro-Deval to Characterize Aggregate Friction Properties. Report 17-02. Auburn University, AL: National Center for Asphalt Technology. http://www.trb.org/Main/Blurbs/175992.aspx (accessed March 26, 2020). 
Hall, J.W., and K.L. Smith, and L. Titus-Glover, and J.C. Wambold, and T.J. Yager, and Z. Rado. 2009. Guide for Pavement Friction. NCHRP Project No. 01-43. Transportation Research Board. http://redlightrobber.com/red/links_pdf/Guide-for-Pavement-FrictionNCHRP-108.pdf (accessed July 2, 2019).

Kowalski, K. J., R. S. McDaniel, and J. Olek. 2010. Identification of Laboratory Technique to Optimize Superpave HMA Surface Friction Characteristics. FHWA/IN/JTRP-2010/06. Purdue University, IN: Joint Transportation Research Program and Indiana Department of Transportation.

https://engineering.purdue.edu/NCSC/research/PDF\%20files/Optimize-Surface-FrictionCharacteristics.pdf (accessed May 26, 2019).

Liang, R. Y. 2013. Long Term Validation of an Accelerated Polishing Test Procedure for HMA Pavements. FHWA/OH-2013/3. University of Akron, OH: Ohio Department of Transportation. https://rosap.ntl.bts.gov/view/dot/26789 (accessed May 15, 2019).

Lu, Q. and B. Steven. 2006. "Friction Testing of Pavement Preservation Treatments: Literature Review." Technical Memorandum UCPRC-TM-2006-10. University of California Pavement Research Center. http://www.ucprc.ucdavis.edu/PDF/UCPRC-TM-200610.pdf (accessed June 20, 2019).

Michigan Department of Transportation. 2019. Procedures for Aggregate Inspection. https://www.michigan.gov/documents/mdot/MDOT_ProceduresForAggregateAcceptance _386509_7.pdf (accessed May 15, 2019).

Mullen, W. G., and J.K. Whitfield, and T.L Matlock. 1977. Implementation for Use of Variable Speed Friction Tester and Small Wheel Circular Track Wear and Polishing Machine for Pavement Skid Resistance. Project ERSD 110-76-2. Raleigh, NC: North Carolina State University Highway Research Program. PDF.

National Center for Asphalt Technology. 2016. Asphalt Technology News. Vol. 28(2). http://eng.auburn.edu/research/centers/ncat/info-pubs/newsletters/newsfall16.pdf (accessed May 26, 2019).

National Highway Traffic Safety Administration. 2017. "Traffic Safety Facts West Virginia." NHTSA. https://cdan.nhtsa.gov/SASStoredProcess/guest?_program=\%2FProduction $\% 2 F A p p s \% 2$ FSTSI\%2FSTSI (accessed May 9, 2019).

Panagouli, O.K., and A. G. Kokkalis. 1998. "Skid resistance and fractal structure of pavement surface." Chaos, Solitons \& Fractals, Vol. 9(3), pp. 493-505. https://doi.org/10.1016/S0960-0779(97)00085-4 (accessed May 11, 2019).

Patrick, J. 2011. "Comparison of the Wehner-Schulze and PSV Test for Estimating the Polishing Resistance of New Zealand Chip Seal Aggregate." Presented at 3rd International Surface Friction Conference, Safer Road Surfaces - Saving Lives. Gold Coast, Australia. https://saferroadsconference.com/wp-content/uploads/2016/05/ArampamoorthyComparison-of-the-WehnerSchulze-and-PSC-V-Test.pdf (accessed May 26, 2019). 
Pavement Interactive. N. d. "Skid Resistance." Pavement Interactive. https://www.pavementinteractive.org/reference-desk/pavement-management/pavementevaluation/skid-resistance/ (accessed May 15, 2019).

Pyrialakou, D. 2020 January 27. Personal interview.

Vollor, T. W., and D. I. Hanson. 2006. Development of Laboratory Procedure for Measuring Friction of HMA Mixtures - Phase I. Report 06-06. Auburn University, AL: National Center for Asphalt Technology. http://www.cyber.auburn.edu/research/centers/ncat/files/reports/2006/rep06-06.pdf (accessed May 26, 2019).

West Virginia Department of Highways. 2018. Aggregate Technician Instruction Manual. Charleston, WV: WVDOH.

West Virginia Department of Highways Materials Control, Soils and Testing Division. Rapid Determination of the Polish Susceptible Carbonate Particle Content in Aggregates. MP 402.02.20. WVDOH, 1995. 


\section{Test Methods Used:}

American Association of State Highway and Transportation Officials. Standard Method of Test for Preparing and Determining the Density of Asphalt Mixture Specimens by Means of the Superpave Gyratory Compactor. AASHTO T312-15. Washington, D.C.: AASHTO, 2015.

American Association of State Highway and Transportation Officials. Standard Method of Test for Bulk Specific Gravity $\left(G_{m b}\right)$ of Compacted Asphalt Mixtures Using Saturated SurfaceDry Specimens. AASHTO T166-16. Washington, D.C.: AASHTO, 2016.

ASTM International. Standard Practice for Accelerated Polishing of Aggregates or Pavement Surfaces Using a Small-Wheel, Circular Track Polishing Machine. ASTM E660-90. West Conshohocken, PA: ASTM International, 2015.

ASTM International. Standard Test Method for Measuring Surface Frictional Properties Using the British Pendulum Tester. ASTM E303-93. West Conshohocken, PA: ASTM International, 2018. 


\title{
Appendix A: Mix Design, Specimen Characteristics, and Field Location Information
}

\author{
Mix Design T400 Sheets
}

T400 SP

04-10

WEST VIRGINIA DIVIS
JOB MIX FORMULA FOR SUP
1462122
J.F. Allen Company
Chadley Miller
Batch
JFA1.02.400

MIX COMPOSITION

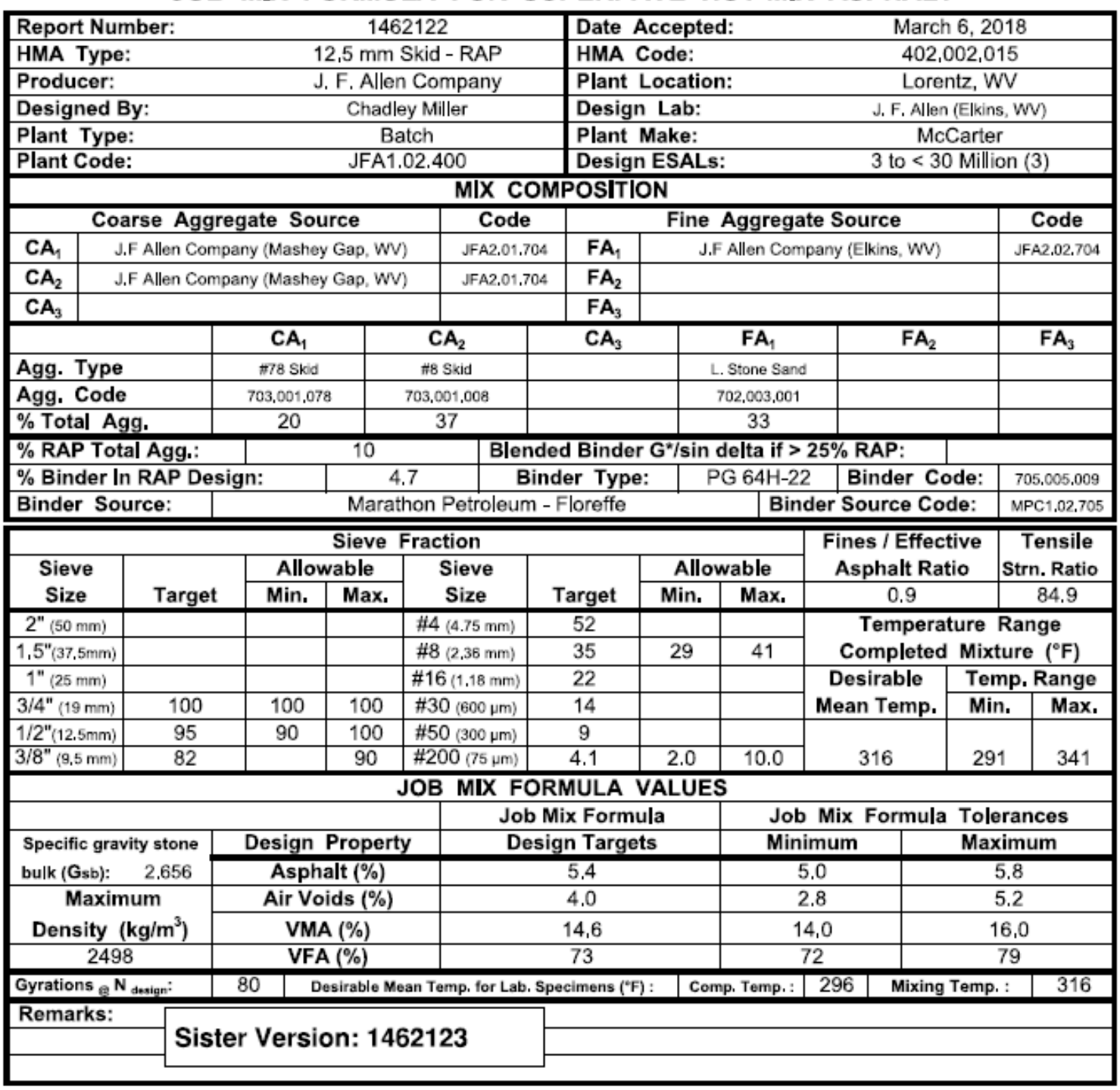

Figure 19: T400 Sheet for JFA 12.5mm SR Mixture 


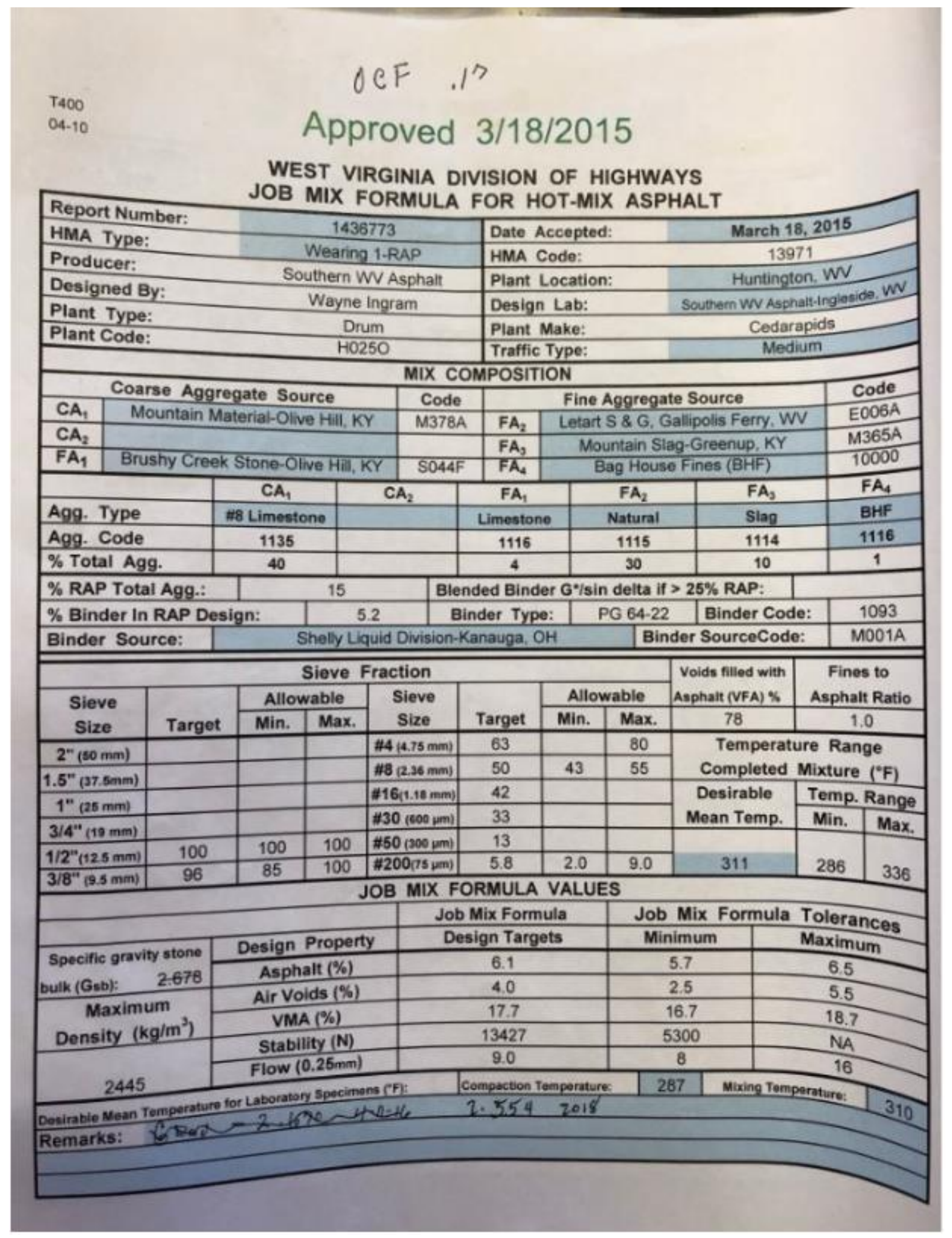

Figure 20: T400 Sheet for WVP WI-RAP Mixture 
T400SP

04-10
WVDOH MCS\&T Approval

Recommended for Approval:

P. Cyrus

Approved By:

WEST VIRGINIA DIVISION OF HIGHWAYS " o31442018 JOB MIX FORMULA FOR SUPERPAVE HOT-MIX ASPHALT

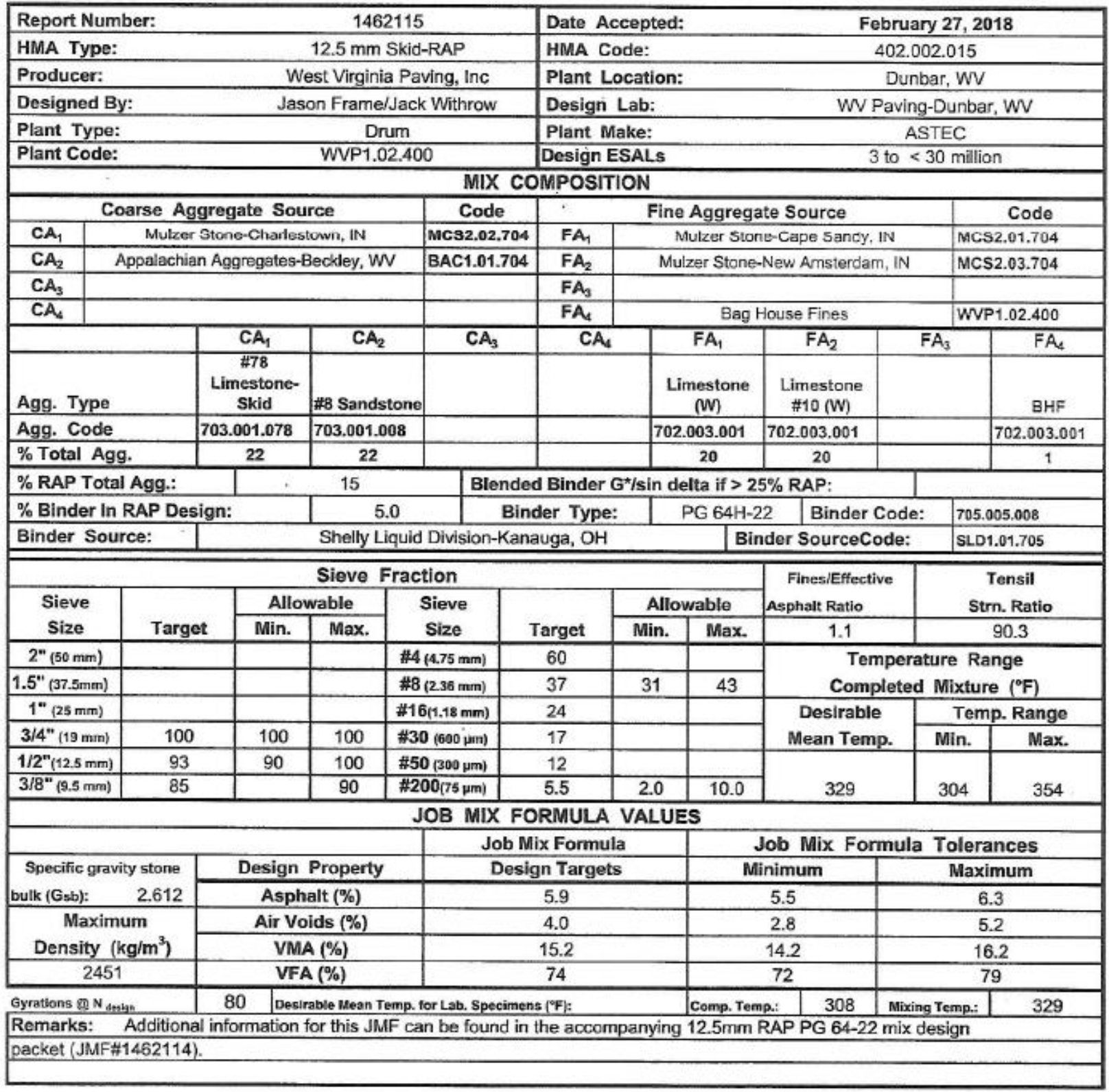

Figure 21: T400 Sheet for WVP 12.5mm SR Mixture 
WEST VIRGINIA DIVISION OF HIGHWAYS JOB MIX FORMULA FOR HOT-MIX ASPHALT

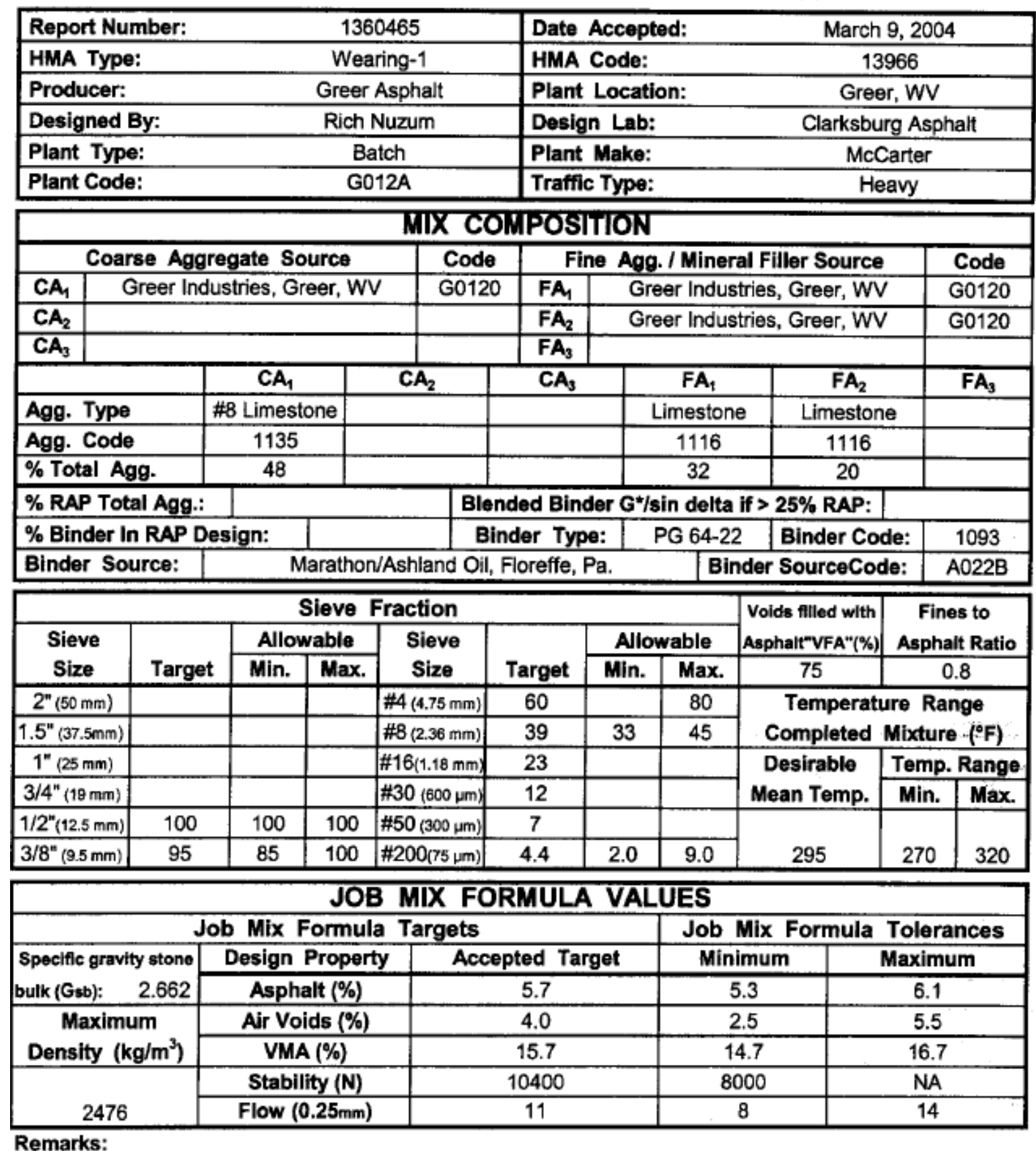

Remarks:

Figure 22: T400 Sheet for Greer W1H Mixture 


\section{Field Core Specimen and Location Information}

\begin{tabular}{|c|c|c|c|c|c|c|c|c|}
\hline & J.F. & $\begin{array}{r}\text { Ilen Comp } \\
\text { Lab Spe } \\
\text { (5) }\end{array}$ & $\begin{array}{l}\text { ny }-17 \\
\text { imen / } \\
\text { of } t \text { s }\end{array}$ & $\begin{array}{l}9 \text { Flatv } \\
\text { Field Co }\end{array}$ & $\begin{array}{l}\text { Ioods GA } \\
\text { Compar } \\
\text { Cab }\end{array}$ & $\begin{array}{l}\text { VEE Projec } \\
\text { on }\end{array}$ & & \\
\hline $\begin{array}{c}\begin{array}{c}\text { Date Produced / } \\
\text { Placed }\end{array} \\
\end{array}$ & Sample ID & Sample Type & $\begin{array}{c}\text { Sample } \\
\text { Gmb }\end{array}$ & $\begin{array}{c}\text { Samplo } \\
\text { Gmm }\end{array}$ & $\begin{array}{c}\text { Sample \% } \\
\text { Compaction } \\
\end{array}$ & $\begin{array}{l}\begin{array}{c}\text { Field Travel } \\
\text { Lane }\end{array} \\
\end{array}$ & $\begin{array}{c}\begin{array}{c}\text { Field Sample } \\
\text { Station }\end{array} \\
\end{array}$ & $\begin{array}{c}\begin{array}{c}\text { Field Sample } \\
\text { Offset }\end{array} \\
\end{array}$ \\
\hline $4 / 22 / 2019$ & $\begin{array}{l}1-A \\
1-B\end{array}$ & $\begin{array}{l}\text { Lab Pill } \\
\text { Field Core }\end{array}$ & $\begin{array}{l}2.392 \\
2.379\end{array}$ & 2.474 & $\begin{array}{l}96.7 \\
96.2\end{array}$ & South - Slow & $3771+74$ & $77^{\prime} \mathrm{RCL}$ \\
\hline $4 / 29 / 2019$ & $\begin{array}{l}2-A \\
2-B\end{array}$ & $\begin{array}{l}\text { Lab Pill } \\
\text { Field Core }\end{array}$ & $\begin{array}{l}2.357 \\
2.375\end{array}$ & 2.477 & $\begin{array}{l}95.2 \\
95.9\end{array}$ & North-Slow & $3798+99$ & 9' $\mathrm{R} \mathrm{cL}$ \\
\hline $4 / 30 / 2019$ & $\begin{array}{l}3-A \\
3-B\end{array}$ & $\begin{array}{l}\text { Lab Pill } \\
\text { Field Core }\end{array}$ & $\begin{array}{l}2.378 \\
2.294\end{array}$ & 2.478 & $\begin{array}{l}96.0 \\
92.6\end{array}$ & North - Slow & $3838+12$ & 7' $\mathrm{R} \mathrm{cL}$ \\
\hline $4 / 30 / 2019$ & $\begin{array}{l}4-A \\
4-B\end{array}$ & $\begin{array}{l}\text { Lab Pill } \\
\text { Field Core }\end{array}$ & $\begin{array}{l}2.401 \\
2.309\end{array}$ & 2.477 & $\begin{array}{l}96.9 \\
93.2\end{array}$ & North - Slow & $3931+52$ & $3^{\prime} \mathrm{R} \mathrm{cL}$ \\
\hline $5 / 1 / 2019$ & $\begin{array}{l}5-A \\
5-B\end{array}$ & $\begin{array}{l}\text { Lab Pill } \\
\text { Field Core }\end{array}$ & $\begin{array}{l}2.379 \\
2.356\end{array}$ & 2.477 & $\begin{array}{l}96.0 \\
95.1\end{array}$ & North - Slow & $3961+35$ & $4^{\prime} \mathrm{R} \mathrm{CL}$ \\
\hline $5 / 7 / 2019$ & $\begin{array}{l}6-A \\
6-B\end{array}$ & $\begin{array}{l}\text { Lab Pill } \\
\text { Field Core }\end{array}$ & $\begin{array}{l}2.361 \\
2.315\end{array}$ & 2.478 & $\begin{array}{l}95.3 \\
93.4\end{array}$ & NB On Ramp & $10+05$ & $10^{\prime} \mathrm{R} \mathrm{CL}$ \\
\hline
\end{tabular}

Figure 23: JFA 12.5mm SR Laboratory Compacted and Field Core Specimen Information 
T-432 (Density)

Rev. 8-2013

WEST VIRGINIA DIVISION OF HIGHWAYS

Worksheet For Recording Core In Place Density and Thickness Sample Data

Enter data in blue shaded areas.

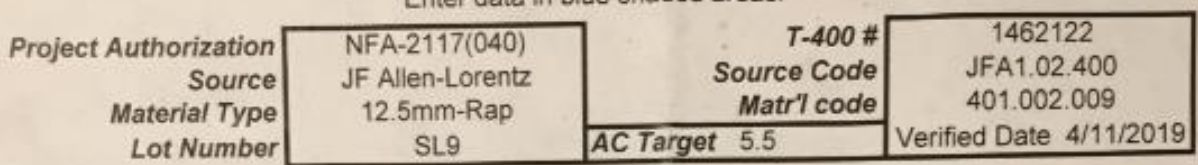

\begin{tabular}{|c|c|c|c|c|c|c|c|}
\hline Technician & $\overline{D W}$ & DW & DW & DW & DW & & \\
\hline Lab Number & & & & & & & \\
\hline Sample ID & SL9-DT1 & SL9-DT2 & SL9-DT3 & SL9-DT4 & SL9-DT5 & SL9-DT6 & SL9-DT7 \\
\hline Station Number & $3795+00$ & $3828+70$ & $3851+49$ & $3882+80$ & $3887+23$ & & \\
\hline Offset & $2 \mathrm{LT}$ & $9^{\prime} L T$ & $g^{\prime} L T$ & $3 \mathrm{LT}$ & $3 \mathrm{LT}$ & & \\
\hline Date Sampled & $04 / 12 / 19$ & $04 / 16 / 19$ & $04 / 16 / 19$ & $04 / 17 / 19$ & $04 / 17 / 19$ & & \\
\hline Date Completed & $04 / 19 / 19$ & $04 / 19 / 19$ & $04 / 19 / 19$ & $04 / 19 / 19$ & $04 / 19 / 19$ & & \\
\hline
\end{tabular}

\begin{tabular}{|c|c|c|c|c|c|c|c|}
\hline \multicolumn{8}{|l|}{ CORE MEASUREMENTS } \\
\hline Sample ID & SL9-DT1 & SL9-DT2 & SL9-DT3 & SL9-DT4 & SL9-DT5 & SL9-DT6 & SL9-DT7 \\
\hline Thickness 1 (mm) & 52 & 53 & 53 & 52 & 51 & & \\
\hline Thickness 2 (mm) & 54 & 53 & 53 & 52 & 51 & & \\
\hline Thickness 3 (mm) & 54 & 55 & 54 & 53 & 50 & & \\
\hline Thickness 4 (mm) & 55 & 55 & 54 & 53 & 50 & & \\
\hline Avg. Thickness (mm) & 53.75 & 54 & 53.5 & 52.5 & 50.5 & & \\
\hline Avg Thickness (Inch) & 2.12 & 2.13 & 2.11 & 2.07 & 1.99 & & \\
\hline
\end{tabular}

\begin{tabular}{|c|c|c|c|c|c|c|c|}
\hline \multicolumn{8}{|l|}{ Density Data } \\
\hline \multirow{13}{*}{$\begin{array}{l}\text { (A) Weight of Bag } \\
\text { (B) Weight of Prepared Sample } \\
\text { (C) Samples Submerged Weight } \\
\text { (D) Weight After Submersion } \\
\text { (E) Ratio...B/A } \\
\text { (F) Bag Apparent Gravity(See note) } \\
\text { (G) Total Volume...(A+D)-C } \\
\text { (H) Volume of Bag...AVF } \\
\text { (I) Volume of Sample...K-L } \\
\text { (J) Bulk Specific Gravity...F/M } \\
\text { (K) Daily Target Gmm } \\
\text { In-Place Density (J/K) } \times 100 \%\end{array}$} & SL9-DT1 & SL9-DT2 & SL9-DT3 & SL9-DT4 & SL9-DT5 & SL9-DT6 & SL9-DT7 \\
\hline & 26.7 & 26.8 & 27 & 27 & 27.3 & & \\
\hline & 2077.4 & 2193.4 & 2202.9 & 2155.1 & 2039.7 & & \\
\hline & 1153.3 & 1256.3 & 1238.8 & 1221.1 & 1164 & & \\
\hline & 2077.3 & 2193.4 & 2202.9 & 2155.2 & 2039.8 & & \\
\hline & 78 & 82 & 82 & 80 & 75 & & \\
\hline & 0.768 & 0.766 & 0.766 & 0.767 & 0.77 & & \\
\hline & 950.7 & 963.9 & 991.1 & 961.1 & 903.1 & & \\
\hline & 34.8 & 35 & 35.2 & 35.2 & 35.5 & & \\
\hline & 915.9 & 928.9 & 955.9 & 925.9 & 867.6 & & \\
\hline & 2.268 & 2.361 & 2.305 & 2.328 & 2.351 & & \\
\hline & 2.487 & 2.481 & 2.481 & 2.476 & 2.476 & & \\
\hline & 91.19 & 95.16 & 92.91 & 94.02 & 94.95 & & \\
\hline & $\uparrow$ & k & $\uparrow$ & $\uparrow$ & $\uparrow$ & & \\
\hline
\end{tabular}

Figure 24: JFA 12.5mm SR I-79 Field Core and Field Measurement Location Information 


\section{Specimen Information}

Table 20: Specimen Characteristics Catalog

\begin{tabular}{|c|c|c|c|c|c|c|}
\hline Specimen & Mixture & NMAS & VTM & Surface & Toe & Tires \\
\hline $1 \mathrm{~T}$ & $\begin{array}{c}\text { JFA } 12.5 \mathrm{~mm} \\
\text { SR }\end{array}$ & $12.5 \mathrm{~mm}$ & $8 \%$ & Top & Low & $\begin{array}{l}\text { Burris } \\
\text { B55A }\end{array}$ \\
\hline $2 \mathrm{~T}$ & $\begin{array}{c}\text { JFA } 12.5 \mathrm{~mm} \\
\text { SR }\end{array}$ & $12.5 \mathrm{~mm}$ & $8 \%$ & Top & Low & $\begin{array}{l}\text { Burris } \\
\text { B55A }\end{array}$ \\
\hline $3 \mathrm{~T}$ & $\begin{array}{c}\text { JFA } 12.5 \mathrm{~mm} \\
\text { SR }\end{array}$ & $12.5 \mathrm{~mm}$ & $8 \%$ & Top & Low & $\begin{array}{l}\text { Burris } \\
\text { B55A }\end{array}$ \\
\hline $4 \mathrm{~T}$ & $\begin{array}{c}\text { JFA } 12.5 \mathrm{~mm} \\
\text { SR }\end{array}$ & $12.5 \mathrm{~mm}$ & $4 \%$ & Top & Low & $\begin{array}{l}\text { Burris } \\
\text { B55A }\end{array}$ \\
\hline $5 \mathrm{~T}$ & $\begin{array}{c}\text { JFA } 12.5 \mathrm{~mm} \\
\text { SR }\end{array}$ & $12.5 \mathrm{~mm}$ & $4 \%$ & Top & Low & $\begin{array}{l}\text { Burris } \\
\text { B55A }\end{array}$ \\
\hline $6 \mathrm{~T}$ & $\begin{array}{c}\text { JFA } 12.5 \mathrm{~mm} \\
\text { SR }\end{array}$ & $12.5 \mathrm{~mm}$ & $4 \%$ & Top & Low & $\begin{array}{l}\text { Burris } \\
\text { B55A }\end{array}$ \\
\hline $7 \mathrm{~T}$ & WVP W1-RAP & $9.5 \mathrm{~mm}$ & $4 \%$ & Top & Low & $\begin{array}{l}\text { Burris } \\
\text { B55A }\end{array}$ \\
\hline $8 \mathrm{~T}$ & WVP W1-RAP & $9.5 \mathrm{~mm}$ & $4 \%$ & Top & Low & $\begin{array}{l}\text { Burris } \\
\text { B55A }\end{array}$ \\
\hline 9T & WVP W1-RAP & $9.5 \mathrm{~mm}$ & $4 \%$ & Top & Low & $\begin{array}{l}\text { Burris } \\
\text { B55A }\end{array}$ \\
\hline $10 \mathrm{~T}$ & WVP W1-RAP & $9.5 \mathrm{~mm}$ & $8 \%$ & Top & Low & $\begin{array}{l}\text { Burris } \\
\text { B55A }\end{array}$ \\
\hline $11 \mathrm{~T}$ & WVP W1-RAP & $9.5 \mathrm{~mm}$ & $8 \%$ & Top & Low & $\begin{array}{l}\text { Burris } \\
\text { B55A }\end{array}$ \\
\hline $12 \mathrm{~T}$ & WVP W1-RAP & $9.5 \mathrm{~mm}$ & $8 \%$ & Top & Low & $\begin{array}{l}\text { Burris } \\
\text { B55A }\end{array}$ \\
\hline 1B & $\begin{array}{c}\text { JFA } 12.5 \mathrm{~mm} \\
\mathrm{SR}\end{array}$ & $12.5 \mathrm{~mm}$ & $8 \%$ & Bottom & High & $\begin{array}{l}\text { Burris } \\
\text { B55A }\end{array}$ \\
\hline $2 \mathrm{~B}$ & $\begin{array}{c}\text { JFA } 12.5 \mathrm{~mm} \\
\text { SR }\end{array}$ & $12.5 \mathrm{~mm}$ & $8 \%$ & Bottom & High & $\begin{array}{l}\text { Burris } \\
\text { B55A }\end{array}$ \\
\hline 3B & $\begin{array}{l}\text { JFA } 12.5 \mathrm{~mm} \\
\text { SR }\end{array}$ & $12.5 \mathrm{~mm}$ & $8 \%$ & Bottom & High & $\begin{array}{l}\text { Burris } \\
\text { B55A }\end{array}$ \\
\hline 4B & $\begin{array}{c}\text { JFA } 12.5 \mathrm{~mm} \\
\text { SR }\end{array}$ & $12.5 \mathrm{~mm}$ & $4 \%$ & Bottom & High & $\begin{array}{l}\text { Burris } \\
\text { B55A }\end{array}$ \\
\hline $5 \mathrm{~B}$ & $\begin{array}{c}\text { JFA } 12.5 \mathrm{~mm} \\
\text { SR }\end{array}$ & $12.5 \mathrm{~mm}$ & $4 \%$ & Bottom & High & $\begin{array}{l}\text { Burris } \\
\text { B55A }\end{array}$ \\
\hline $6 \mathrm{~B}$ & $\begin{array}{c}\text { JFA } 12.5 \mathrm{~mm} \\
\text { SR }\end{array}$ & $12.5 \mathrm{~mm}$ & $4 \%$ & Bottom & High & $\begin{array}{l}\text { Burris } \\
\text { B55A }\end{array}$ \\
\hline $7 \mathrm{~B}$ & WVP W1-RAP & $9.5 \mathrm{~mm}$ & $4 \%$ & Bottom & High & $\begin{array}{l}\text { Burris } \\
\text { B55A }\end{array}$ \\
\hline $8 \mathrm{~B}$ & WVP W1-RAP & $9.5 \mathrm{~mm}$ & $4 \%$ & Bottom & High & $\begin{array}{l}\text { Burris } \\
\text { B55A }\end{array}$ \\
\hline
\end{tabular}




\begin{tabular}{|c|c|c|c|c|c|c|}
\hline Specimen & Mixture & NMAS & VTM & Surface & Toe & Tires \\
\hline $9 B$ & WVP W1-RAP & $9.5 \mathrm{~mm}$ & $4 \%$ & Bottom & High & $\begin{array}{l}\text { Burris } \\
\text { B55A }\end{array}$ \\
\hline $10 \mathrm{~B}$ & WVP W1-RAP & $9.5 \mathrm{~mm}$ & $8 \%$ & Bottom & High & $\begin{array}{l}\text { Burris } \\
\text { B55A }\end{array}$ \\
\hline $11 \mathrm{~B}$ & WVP W1-RAP & $9.5 \mathrm{~mm}$ & $8 \%$ & Bottom & High & $\begin{array}{l}\text { Burris } \\
\text { B55A }\end{array}$ \\
\hline $12 \mathrm{~B}$ & WVP W1-RAP & $9.5 \mathrm{~mm}$ & $8 \%$ & Bottom & High & $\begin{array}{l}\text { Burris } \\
\text { B55A }\end{array}$ \\
\hline $13 \mathrm{~T}$ & Greer W1H & $9.5 \mathrm{~mm}$ & $8 \%$ & Top & High & $\begin{array}{c}\text { Hoosier } \\
\text { R80 }\end{array}$ \\
\hline $14 \mathrm{~T}$ & Greer W1H & $9.5 \mathrm{~mm}$ & $8 \%$ & Top & High & $\begin{array}{c}\text { Hoosier } \\
\text { R80 }\end{array}$ \\
\hline $15 \mathrm{~T}$ & Greer W1H & $9.5 \mathrm{~mm}$ & $8 \%$ & Top & High & $\begin{array}{c}\text { Hoosier } \\
\text { R80 }\end{array}$ \\
\hline $16 \mathrm{~T}$ & Greer W1H & $9.5 \mathrm{~mm}$ & $4 \%$ & Top & High & $\begin{array}{c}\text { Hoosier } \\
\text { R80 }\end{array}$ \\
\hline $17 \mathrm{~T}$ & Greer W1H & $9.5 \mathrm{~mm}$ & $4 \%$ & Top & High & $\begin{array}{c}\text { Hoosier } \\
\text { R80 }\end{array}$ \\
\hline $18 \mathrm{~T}$ & Greer W1H & $9.5 \mathrm{~mm}$ & $4 \%$ & Top & High & $\begin{array}{c}\text { Hoosier } \\
\text { R80 }\end{array}$ \\
\hline $19 \mathrm{~T}$ & $\begin{array}{c}\text { WVP } 12.5 \mathrm{~mm} \\
\text { SR }\end{array}$ & $12.5 \mathrm{~mm}$ & $4 \%$ & Top & High & $\begin{array}{c}\text { Hoosier } \\
\text { R80 }\end{array}$ \\
\hline $20 \mathrm{~T}$ & $\begin{array}{c}\text { WVP } 12.5 \mathrm{~mm} \\
\text { SR }\end{array}$ & $12.5 \mathrm{~mm}$ & $4 \%$ & Top & High & $\begin{array}{c}\text { Hoosier } \\
\text { R80 }\end{array}$ \\
\hline $21 \mathrm{~T}$ & $\begin{array}{c}\text { WVP } 12.5 \mathrm{~mm} \\
\text { SR }\end{array}$ & $12.5 \mathrm{~mm}$ & $4 \%$ & Top & High & $\begin{array}{c}\text { Hoosier } \\
\text { R80 }\end{array}$ \\
\hline $22 \mathrm{~T}$ & $\begin{array}{c}\text { WVP } 12.5 \mathrm{~mm} \\
\text { SR }\end{array}$ & $12.5 \mathrm{~mm}$ & $8 \%$ & Top & High & $\begin{array}{c}\text { Hoosier } \\
\text { R80 }\end{array}$ \\
\hline $23 \mathrm{~T}$ & $\begin{array}{c}\text { WVP } 12.5 \mathrm{~mm} \\
\text { SR }\end{array}$ & $12.5 \mathrm{~mm}$ & $8 \%$ & Top & High & $\begin{array}{c}\text { Hoosier } \\
\text { R80 }\end{array}$ \\
\hline $24 \mathrm{~T}$ & $\begin{array}{c}\text { WVP } 12.5 \mathrm{~mm} \\
\text { SR }\end{array}$ & $12.5 \mathrm{~mm}$ & $8 \%$ & Top & High & $\begin{array}{c}\text { Hoosier } \\
\text { R80 }\end{array}$ \\
\hline $13 \mathrm{~B}$ & Greer W1H & $9.5 \mathrm{~mm}$ & $8 \%$ & Bottom & Low & $\begin{array}{c}\text { Hoosier } \\
\text { R80 }\end{array}$ \\
\hline 14B & Greer W1H & $9.5 \mathrm{~mm}$ & $8 \%$ & Bottom & Low & $\begin{array}{c}\text { Hoosier } \\
\text { R80 }\end{array}$ \\
\hline $15 B$ & Greer W1H & $9.5 \mathrm{~mm}$ & $8 \%$ & Bottom & Low & $\begin{array}{c}\text { Hoosier } \\
\text { R80 }\end{array}$ \\
\hline $16 \mathrm{~B}$ & Greer W1H & $9.5 \mathrm{~mm}$ & $4 \%$ & Bottom & Low & $\begin{array}{c}\text { Hoosier } \\
\text { R80 }\end{array}$ \\
\hline 17B & Greer W1H & $9.5 \mathrm{~mm}$ & $4 \%$ & Bottom & Low & $\begin{array}{c}\text { Hoosier } \\
\text { R80 }\end{array}$ \\
\hline $18 \mathrm{~B}$ & Greer W1H & $9.5 \mathrm{~mm}$ & $4 \%$ & Bottom & Low & $\begin{array}{c}\text { Hoosier } \\
\text { R80 }\end{array}$ \\
\hline
\end{tabular}




\begin{tabular}{|c|c|c|c|c|c|c|}
\hline Specimen & Mixture & NMAS & VTM & Surface & Toe & Tires \\
\hline $19 B$ & $\begin{array}{c}\text { WVP } 12.5 \mathrm{~mm} \\
\text { SR }\end{array}$ & $12.5 \mathrm{~mm}$ & $4 \%$ & Bottom & Low & $\begin{array}{c}\text { Hoosier } \\
\text { R80 }\end{array}$ \\
\hline $20 B$ & $\begin{array}{c}\text { WVP } 12.5 \mathrm{~mm} \\
\text { SR }\end{array}$ & $12.5 \mathrm{~mm}$ & $4 \%$ & Bottom & Low & $\begin{array}{c}\text { Hoosier } \\
\text { R80 }\end{array}$ \\
\hline $21 B$ & $\begin{array}{c}\text { WVP } 12.5 \mathrm{~mm} \\
\text { SR }\end{array}$ & $12.5 \mathrm{~mm}$ & $4 \%$ & Bottom & Low & $\begin{array}{c}\text { Hoosier } \\
\text { R80 }\end{array}$ \\
\hline $22 B$ & $\begin{array}{c}\text { WVP } 12.5 \mathrm{~mm} \\
\text { SR }\end{array}$ & $12.5 \mathrm{~mm}$ & $8 \%$ & Bottom & Low & $\begin{array}{c}\text { Hoosier } \\
\text { R80 }\end{array}$ \\
\hline $23 \mathrm{~B}$ & $\begin{array}{c}\text { WVP } 12.5 \mathrm{~mm} \\
\text { SR }\end{array}$ & $12.5 \mathrm{~mm}$ & $8 \%$ & Bottom & Low & $\begin{array}{c}\text { Hoosier } \\
\text { R80 }\end{array}$ \\
\hline $24 B$ & $\begin{array}{c}\text { WVP } 12.5 \mathrm{~mm} \\
\text { SR } \\
\end{array}$ & $12.5 \mathrm{~mm}$ & $8 \%$ & Bottom & Low & $\begin{array}{c}\text { Hoosier } \\
\text { R80 }\end{array}$ \\
\hline $25 \mathrm{~T}$ & $\begin{array}{c}\text { JFA } 12.5 \mathrm{~mm} \\
\text { SR } \\
\end{array}$ & $12.5 \mathrm{~mm}$ & $4 \%$ & Top & High & $\begin{array}{c}\text { Hoosier } \\
\text { R80 }\end{array}$ \\
\hline $26 \mathrm{~T}$ & $\begin{array}{c}\text { JFA } 12.5 \mathrm{~mm} \\
\text { SR }\end{array}$ & $12.5 \mathrm{~mm}$ & $4 \%$ & Top & High & $\begin{array}{c}\text { Hoosier } \\
\text { R80 }\end{array}$ \\
\hline $27 \mathrm{~T}$ & $\begin{array}{c}\text { JFA } 12.5 \mathrm{~mm} \\
\text { SR }\end{array}$ & $12.5 \mathrm{~mm}$ & $4 \%$ & Top & High & $\begin{array}{c}\text { Hoosier } \\
\text { R80 }\end{array}$ \\
\hline $28 \mathrm{~T}$ & $\begin{array}{c}\text { JFA } 12.5 \mathrm{~mm} \\
\text { SR } \\
\end{array}$ & $12.5 \mathrm{~mm}$ & $8 \%$ & Top & High & $\begin{array}{c}\text { Hoosier } \\
\text { R80 }\end{array}$ \\
\hline $29 \mathrm{~T}$ & $\begin{array}{c}\text { JFA } 12.5 \mathrm{~mm} \\
\text { SR }\end{array}$ & $12.5 \mathrm{~mm}$ & $8 \%$ & Top & High & $\begin{array}{c}\text { Hoosier } \\
\text { R80 }\end{array}$ \\
\hline $30 \mathrm{~T}$ & $\begin{array}{c}\text { JFA } 12.5 \mathrm{~mm} \\
\text { SR }\end{array}$ & $12.5 \mathrm{~mm}$ & $8 \%$ & Top & High & $\begin{array}{c}\text { Hoosier } \\
\text { R80 }\end{array}$ \\
\hline $31 \mathrm{~T}$ & WVP W1-RAP & $9.5 \mathrm{~mm}$ & $4 \%$ & Top & High & $\begin{array}{c}\text { Hoosier } \\
\text { R80 }\end{array}$ \\
\hline $32 \mathrm{~T}$ & WVP W1-RAP & $9.5 \mathrm{~mm}$ & $4 \%$ & Top & High & $\begin{array}{c}\text { Hoosier } \\
\text { R80 }\end{array}$ \\
\hline $33 \mathrm{~T}$ & WVP W1-RAP & $9.5 \mathrm{~mm}$ & $4 \%$ & Top & High & $\begin{array}{c}\text { Hoosier } \\
\text { R80 }\end{array}$ \\
\hline $34 \mathrm{~T}$ & WVP W1-RAP & $9.5 \mathrm{~mm}$ & $8 \%$ & Top & High & $\begin{array}{c}\text { Hoosier } \\
\text { R80 }\end{array}$ \\
\hline $35 \mathrm{~T}$ & WVP W1-RAP & $9.5 \mathrm{~mm}$ & $8 \%$ & Top & High & $\begin{array}{c}\text { Hoosier } \\
\text { R80 } \\
\end{array}$ \\
\hline $36 \mathrm{~T}$ & WVP W1-RAP & $9.5 \mathrm{~mm}$ & $8 \%$ & Top & High & $\begin{array}{c}\text { Hoosier } \\
\text { R80 }\end{array}$ \\
\hline $25 B$ & $\begin{array}{c}\text { JFA } 12.5 \mathrm{~mm} \\
\text { SR }\end{array}$ & $12.5 \mathrm{~mm}$ & $4 \%$ & Bottom & Low & $\begin{array}{c}\text { Hoosier } \\
\text { R80 }\end{array}$ \\
\hline $26 B$ & $\begin{array}{c}\text { JFA } 12.5 \mathrm{~mm} \\
\text { SR } \\
\end{array}$ & $12.5 \mathrm{~mm}$ & $4 \%$ & Bottom & Low & $\begin{array}{c}\text { Hoosier } \\
\text { R80 }\end{array}$ \\
\hline $27 \mathrm{~B}$ & $\begin{array}{c}\text { JFA } 12.5 \mathrm{~mm} \\
\text { SR }\end{array}$ & $12.5 \mathrm{~mm}$ & $4 \%$ & Bottom & Low & $\begin{array}{c}\text { Hoosier } \\
\text { R80 }\end{array}$ \\
\hline $28 \mathrm{~B}$ & $\begin{array}{c}\text { JFA } 12.5 \mathrm{~mm} \\
\text { SR } \\
\end{array}$ & $12.5 \mathrm{~mm}$ & $8 \%$ & Bottom & Low & $\begin{array}{c}\text { Hoosier } \\
\text { R80 }\end{array}$ \\
\hline
\end{tabular}




\begin{tabular}{|c|c|c|c|c|c|c|}
\hline Specimen & Mixture & NMAS & VTM & Surface & Toe & Tires \\
\hline 29B & $\begin{array}{c}\text { JFA 12.5mm } \\
\text { SR }\end{array}$ & $12.5 \mathrm{~mm}$ & $8 \%$ & Bottom & Low & $\begin{array}{c}\text { Hoosier } \\
\text { R80 }\end{array}$ \\
\hline 30B & $\begin{array}{c}\text { JFA 12.5mm } \\
\text { SR }\end{array}$ & $12.5 \mathrm{~mm}$ & $8 \%$ & Bottom & Low & $\begin{array}{c}\text { Hoosier } \\
\text { R80 }\end{array}$ \\
\hline 32B & WVP W1-RAP & $9.5 \mathrm{~mm}$ & $4 \%$ & Bottom & Low & $\begin{array}{c}\text { Hoosier } \\
\text { R80 }\end{array}$ \\
\hline 33B & WVP W1-RAP & $9.5 \mathrm{~mm}$ & $4 \%$ & Bottom & Low & $\begin{array}{c}\text { Hoosier } \\
\text { R80 }\end{array}$ \\
\hline $34 \mathrm{~B}$ & WVP W1-RAP & $9.5 \mathrm{~mm}$ & $8 \%$ & Bottom & Low & $\begin{array}{c}\text { Hoosier } \\
\text { R80 }\end{array}$ \\
\hline 35B & WVP W1-RAP & $9.5 \mathrm{~mm}$ & $8 \%$ & Bottom & Low & $\begin{array}{c}\text { Hoosier } \\
\text { R80 }\end{array}$ \\
\hline 36B & WVP W1-RAP & $9.5 \mathrm{~mm}$ & $8 \%$ & Bottom & Low & $\begin{array}{c}\text { Hoosier } \\
\text { R80 }\end{array}$ \\
\hline
\end{tabular}




\section{Appendix B: Polishing Procedure}

\section{Polishing}

1. Prepare and label 12 specimens at desired VTM using SGC.

2. Mark specimens with a vertical line for equipment placement, Figure 23.

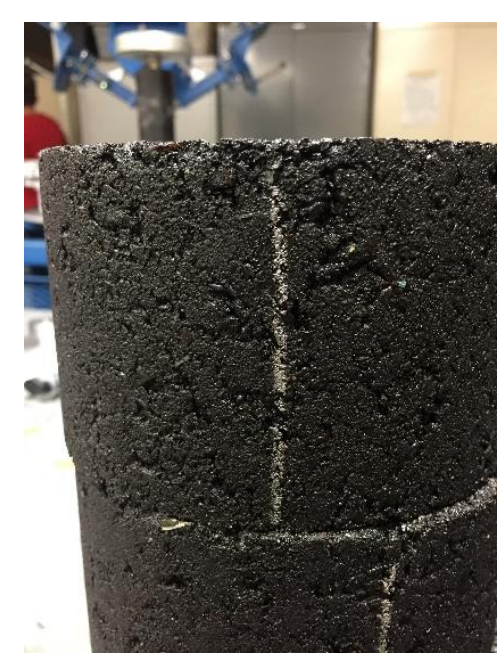

Figure 25: Vertical Sample Markings

3. Perform BPT measurements as per ASTM E303 for each sample prior to placement in the polishing machine.

4. Randomize sample positions in the polishing machine to reduce bias.

5. Place dry specimens in the polishing machine by aligning vertical markings with the clamp opening and adjusting height sample surface to be flush with top plate of machine. Proper specimen placement is pictured below in Figure 25. 


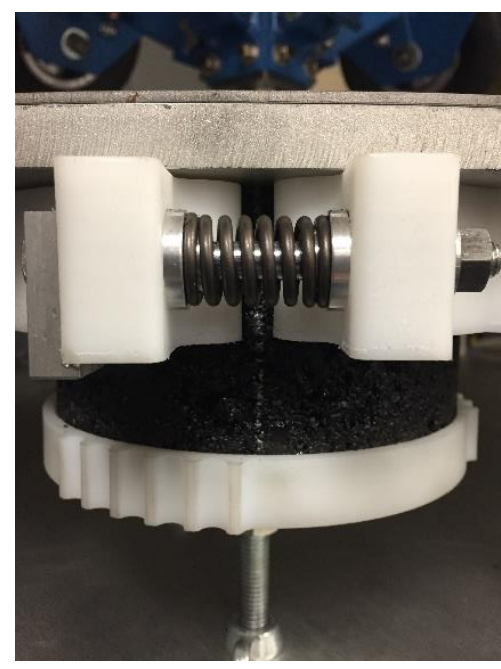

(a)

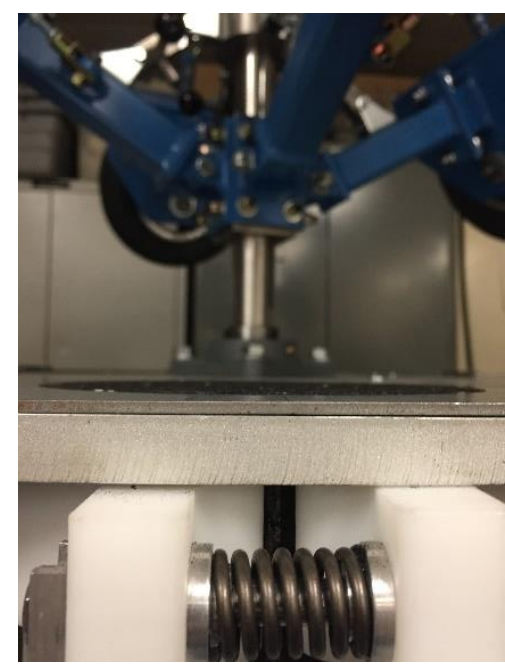

(b)

Figure 26: (a) Specimen Vertical Alignment; (b) Specimen Flushed with Surface Plate

7. Tighten all height adjustment and clamping bolts to ensure zero movement.

8. Record specimen surface temperatures and both the tire tread and sidewall temperatures with an infrared laser thermometer gun for documentation.

9. Measure 2 grams of silicon carbide abrasive powder and distribute over each specimen surface, Figure 26.

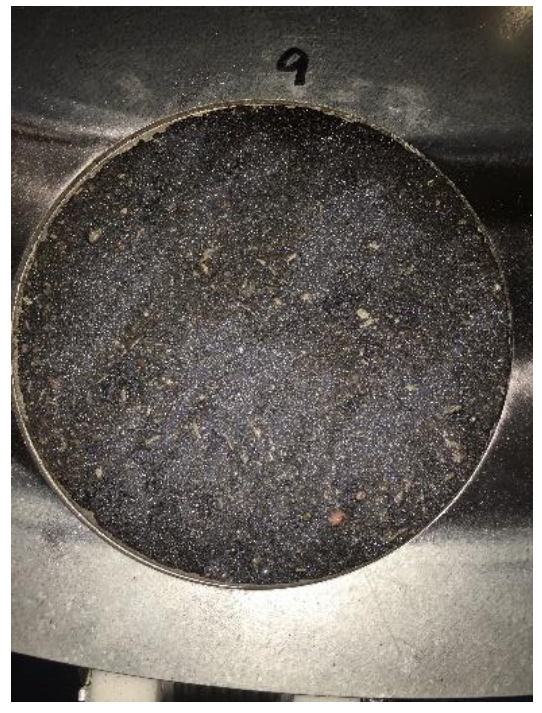

Figure 27: Silicon Carbide Abrasive Distribution on Specimen 
10. Lower the wheel assembly down carefully and place two 25-pound weights on top of each wheel assembly.

11. Latch safety gates and turn the machine on.

12. With the drive (Figure 27) initially set to "zero," press "system reset" and adjust to desired rotation speed to begin polishing. In this experiment, the desired speed was marked for consistent polishing, Figure $27 \mathrm{~b}$. The speed marked was approximately 30 revolutions per minute (rpm).

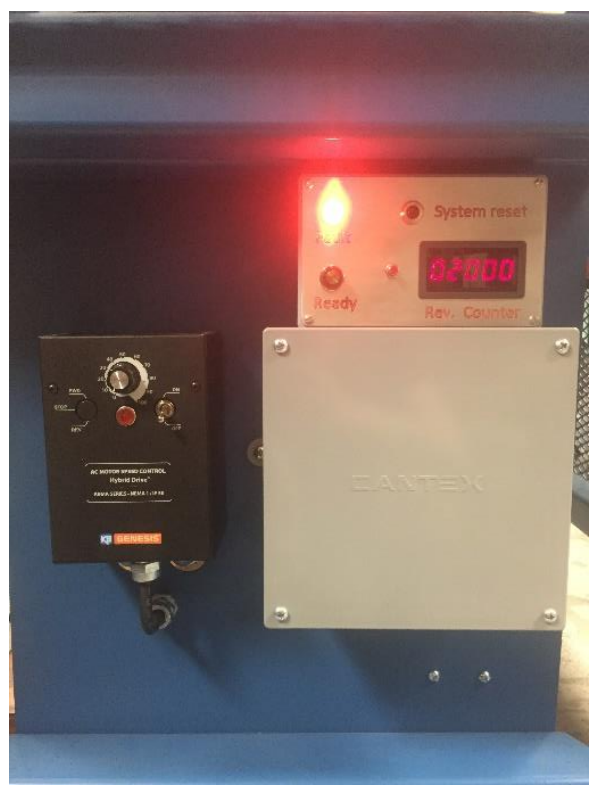

(a)

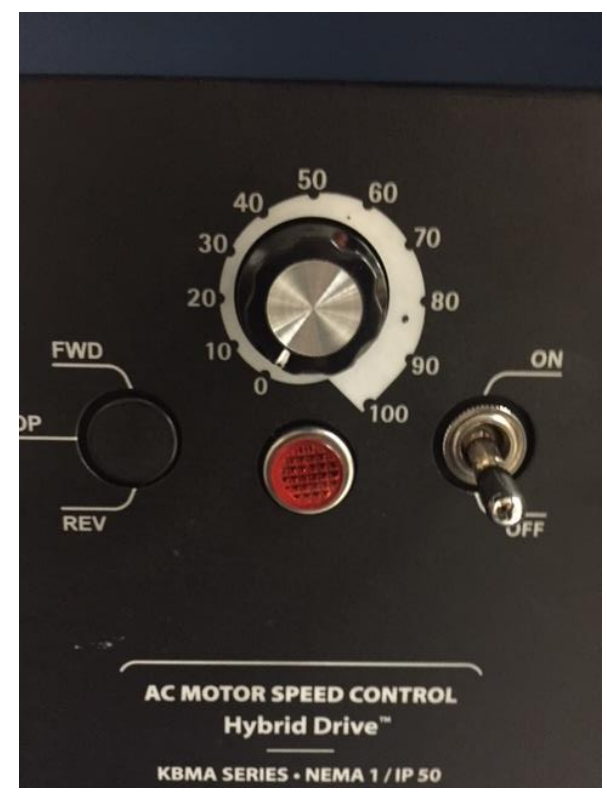

(b)

Figure 28: (a) General Equipment Controls; (b) Variable Speed Drive

13. When desired polishing is achieved, press the "stop" button.

14. When the polishing machine is fully stopped, measure specimen surface and tire temperatures to track initial and final temperatures (if applicable). Examples of these measurements are displayed in the Appendix C. 
15. Remove excess abrasive from specimen surfaces. In this experiment, an air hose was used initially to remove abrasive while specimens remained in the machine. Following specimen removal, a vacuum was used to remove any remaining abrasive from surfaces. This is an important step in the procedure to ensure abrasive has no influence on BPT results.

16. Perform BPT measurements.

17. Repeat above steps for each round of polishing until desired ending is reached.

\section{Sample Removal}

1. Place wheel arms in the locked position as pictured previously in Figure 28.

2. Loosen clamp assembly to allow sample movement. Note: It is not necessary to loosen the height adjustment mechanism to remove specimens.

3. Using the removal tools (Figure 28), push on specimens in the upward direction via the holes in the plastic holding platens, and lift specimens from the machine. Height adjustments will not be affected.

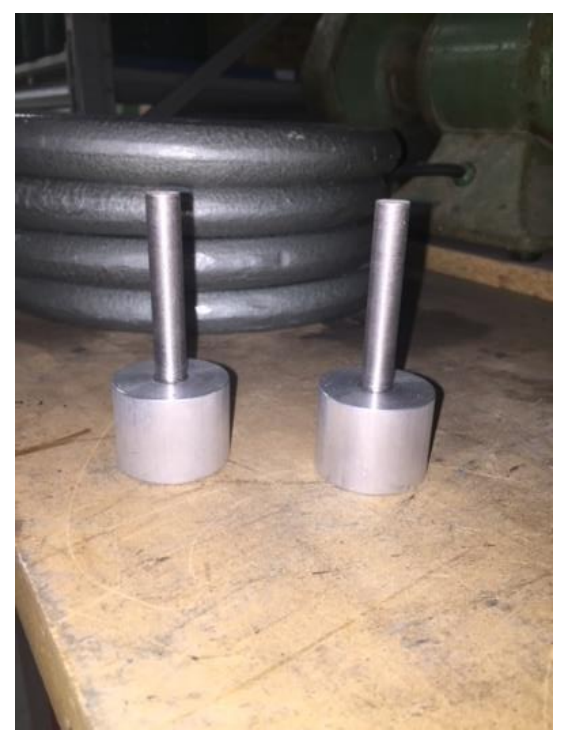

Figure 29: Specimen Removal Tools 


\section{Tire Hardness}

1. Ensure tires are fully cooled (room temperature) before measuring hardness.

2. Remove tires from machine. This is done by loosening the nuts from the hub and pulling the tire and hub assembly directly from the axle.

3. Assemble durometer by attaching the weight carefully, Figure 29.

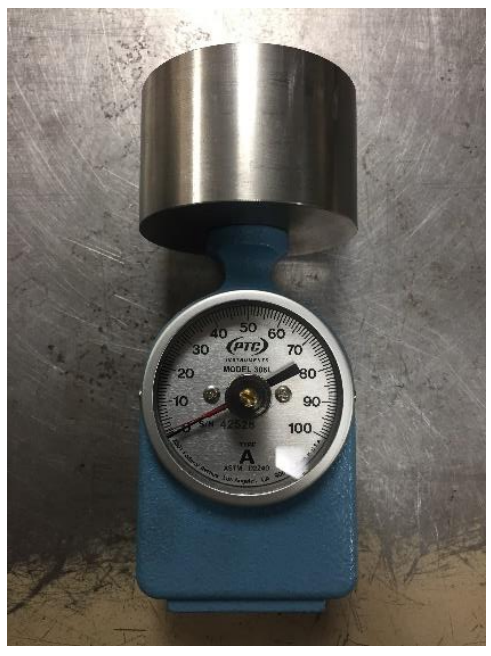

Figure 30: Durometer with Weight Attached

4. Make sure durometer needle is located at the "zero" position before performing measurements.

5. Place durometer above tire vertically, and carefully roll over tire surface. Durometer should remain perpendicular to tire surface for proper measurements. Record measurement as per the marking needle. For this experiment, hardness was measured on the outside edge of the tire tread (side with valve pointing outwards), inside edge of the tire tread, center of the tire tread, and the sidewall of the tire. Tire hardness measurements are located in Appendix C.

6. Repeat for all 4 tires. 


\section{Additional Procedure Notes}

The procedure listed above is a generalized polishing procedure developed using results and observations documented throughout the length of this thesis experiment. It should be noted that a portion of the procedural steps are specific to this particular experiment and can be adjusted according to the scope of testing. Details specific to this experiment and those which can be modified as per user discretion include:

- Polishing wheel pass increments were chosen as 8000, 16000, 32000, and 48000 passes. The number of increments can be increased or decreased dependent on desired outcomes. A total of 48,000 wheel passes were deemed sufficient for analysis during this experiment.

- Corresponding to the chosen polishing increments, tire hardness was monitored prior to use as well as following 16000, 32000, and 48000 wheel passes in the polishing machine.

- Silicon abrasive powder was placed on specimen surfaces prior to each polishing session. This can be altered based on the scope of testing.

- Sample tracking pictures and temperature tracking measurements were taken for documentation purposes throughout the experiment. This can be withdrawn from the procedure if the information is not valuable to the user. 


\section{Appendix C: Specimen and Experiment Tracking Data}

\section{Specimen Surface Temperature}

Table 21: Trial 2 JFA 12.5mm SR and WVP W1-RAP Initial and Final Surface Temperatures $\left({ }^{\circ}\right.$ F) During Polishing Procedure

\begin{tabular}{|c|c|c|c|c|c|c|c|c|c|c|c|c|c|}
\hline \multirow{3}{*}{ Polishing Position } & \multirow{3}{*}{ Specimen Number } & \multicolumn{12}{|c|}{ Surface Temperature at Each Wheel Pass Increment } \\
\hline & & \multicolumn{3}{|c|}{8000} & \multicolumn{3}{|c|}{\begin{tabular}{|c|}
16000 \\
\end{tabular}} & \multicolumn{3}{|c|}{32000} & \multicolumn{3}{|c|}{48000} \\
\hline & & Initial & Final & Difference & Initial & Final & Difference & Initial & Final & Difference & Initial & Final & Difference \\
\hline 1 & $7 \mathrm{~T}$ & 77.5 & 82.4 & 4.9 & 75.3 & 80.4 & 5.1 & 77.3 & 82 & 4.7 & 76 & 79.8 & 3.8 \\
\hline 2 & $6 \mathrm{~T}$ & 77.1 & 82.9 & 5.8 & 75.7 & 79.7 & 4 & 76.6 & 82 & 5.4 & 76 & 80.2 & 4.2 \\
\hline 3 & $12 \mathrm{~T}$ & 77.1 & 83.3 & 6.2 & 75.3 & 80.9 & 5.6 & 77 & 80.6 & 3.6 & 76.2 & 80.2 & 4 \\
\hline 4 & $9 \mathrm{~T}$ & 77.1 & 83.1 & 6 & 75.7 & 81.3 & 5.6 & 75.9 & 82.4 & 6.5 & 76 & 79.8 & 3.8 \\
\hline 5 & $11 \mathrm{~T}$ & 76.6 & 83.3 & 6.7 & 75.7 & 80.0 & 4.3 & 76.6 & 82 & 5.4 & 76 & 80.2 & 4.2 \\
\hline 6 & $10 \mathrm{~T}$ & 77.1 & 83.3 & 6.2 & 75.7 & 80.9 & 5.2 & 77.7 & 80.7 & 3 & 76 & 80.8 & 4.8 \\
\hline 7 & $4 \mathrm{~T}$ & 76.8 & 82 & 5.2 & 75.7 & 77.5 & 1.8 & 78 & 82 & 4 & 75.9 & 79.1 & 3.2 \\
\hline 8 & $2 \mathrm{~T}$ & 76.6 & 83.3 & 6.7 & 75.3 & 78.4 & 3.1 & 77.7 & 82.4 & 4.7 & 75.3 & 79.8 & 4.5 \\
\hline 9 & $1 \mathrm{~T}$ & 76.6 & 83.6 & 7 & 75.2 & 80.9 & 5.7 & 76.6 & 80.6 & 4 & 76 & 80 & 4 \\
\hline 10 & $8 \mathrm{~T}$ & 77.5 & 82.4 & 4.9 & 75.5 & 80.4 & 4.9 & 75.5 & 80.6 & 5.1 & 75.3 & 79.7 & 4.4 \\
\hline 11 & $3 \mathrm{~T}$ & 76.6 & 83.6 & 7 & 75.5 & 81.1 & 5.6 & 77 & 81.8 & 4.8 & 74.3 & 80.4 & 6.1 \\
\hline 12 & $5 \mathrm{~T}$ & 77.1 & 83.6 & 6.5 & 75.2 & 81.1 & 5.9 & 75.9 & 81.1 & 5.2 & 75.9 & 76.6 & 0.7 \\
\hline & & \multicolumn{2}{|c|}{ Average } & 6.1 & \multicolumn{2}{|c|}{ Average } & 4.7 & \multicolumn{2}{|c|}{ Average } & 4.7 & \multicolumn{2}{|c|}{ Average } & 4.0 \\
\hline
\end{tabular}


Table 22: Trial 3 JFA 12.5mm SR and WVP W1-RAP Initial and Final Surface Temperatures ( $\left.{ }^{\circ} \mathrm{F}\right)$ During Polishing Procedure

\begin{tabular}{|c|c|c|c|c|c|c|c|c|c|c|c|c|c|c|c|c|c|c|c|}
\hline \multirow{3}{*}{ Polishing Position } & \multirow{3}{*}{ Specimen Number } & \multicolumn{18}{|c|}{ Surface Temperature at Each Wheel Pass Increment } \\
\hline & & \multicolumn{3}{|c|}{8000} & \multicolumn{3}{|c|}{16000} & \multicolumn{3}{|c|}{32000} & \multicolumn{3}{|c|}{48000} & \multicolumn{3}{|c|}{64000} & \multicolumn{3}{|c|}{80000} \\
\hline & & Initial & Final & Difference & Initial & Final & Difference & Initial & Final & Difference & Initial & Final & Difference & Initial & Final & Difference & Initial & Final & Difference \\
\hline 1 & $7 \mathrm{~B}$ & 74.8 & 85.8 & 11 & 76.1 & 86.7 & 10.6 & 73.4 & 87.4 & 14 & 75.3 & 87.6 & 12.3 & 74.8 & 86.7 & 11.9 & 75.3 & 84.7 & 9.4 \\
\hline 2 & 6B & 74.3 & 86.3 & 12 & 76.8 & 86.9 & 10.1 & 73 & 87 & 14 & 75.3 & 87.6 & 12.3 & 75 & 86.3 & 11.3 & 76.4 & 84.7 & 8.3 \\
\hline 3 & $12 \mathrm{~B}$ & 74.3 & 85.1 & 10.8 & 76.8 & 85.4 & 8.6 & 73 & 85.3 & 12.3 & 76.1 & 87 & 10.9 & 75 & 85.8 & 10.8 & 75 & 84.3 & 9.3 \\
\hline 4 & $9 \mathrm{~B}$ & 74.8 & 86 & 11.2 & 76.8 & 87 & 10.2 & 73.4 & 87.2 & 13.8 & 75.7 & 87.9 & 12.2 & 75.3 & 86.5 & 11.2 & 75.3 & 85.1 & 9.8 \\
\hline 5 & 11B & 74.8 & 86.3 & 11.5 & 76.4 & 86.7 & 10.3 & 73 & 87.6 & 14.6 & 75.7 & 87.9 & 12.2 & 75 & 87 & 12 & 75.3 & 85.1 & 9.8 \\
\hline 6 & $10 \mathrm{~B}$ & 74.4 & 86.7 & 12.3 & 76.8 & 87 & 10.2 & 73.7 & 85.2 & 11.5 & 76.4 & 87.4 & 11 & 75.3 & 85.8 & 10.5 & 75.3 & 84.5 & 9.2 \\
\hline 7 & $4 \mathrm{~B}$ & 74.3 & 86 & 11.7 & 76.4 & 87 & 10.6 & 73 & 87.6 & 14.6 & 75.7 & 87.2 & 11.5 & 74.8 & 86.9 & 12.1 & 75 & 85.1 & 10.1 \\
\hline 8 & $2 \mathrm{~B}$ & 74.8 & 86 & 11.2 & 76.8 & 86.3 & 9.5 & 73 & 87.2 & 14.2 & 75.7 & 87.6 & 11.9 & 75 & 87 & 12 & 74.6 & 85.1 & 10.5 \\
\hline 9 & 1B & 74.4 & 85.4 & 11 & 76.8 & 86.7 & 9.9 & 73.4 & 86 & 12.6 & 75.7 & 87.8 & 12.1 & 75 & 86.1 & 11.1 & 75.7 & 84.9 & 9.2 \\
\hline 10 & 8B & 75.2 & 86.7 & 11.5 & 76.4 & 86.7 & 10.3 & 73.4 & 87.2 & 13.8 & 76.4 & 87.8 & 11.4 & 75 & 87 & 12 & 75.3 & 85.4 & 10.1 \\
\hline 11 & $3 \mathrm{~B}$ & 74.3 & 86.7 & 12.4 & 76.1 & 87 & 10.9 & 73.4 & 87.6 & 14.2 & 75.7 & 88.1 & 12.4 & 75 & 87 & 12 & 75 & 84.7 & 9.7 \\
\hline 12 & $5 \mathrm{~B}$ & 74.3 & 86 & 11.7 & 76.8 & 86.7 & 9.9 & 73 & 86.3 & 13.3 & 76.1 & 88.1 & 12 & 74.8 & 86.5 & 11.7 & 75 & 83.6 & 8.6 \\
\hline & & \multicolumn{2}{|c|}{ Average } & 11.5 & \multicolumn{2}{|c|}{ Average } & 10.1 & \multicolumn{2}{|c|}{ Average } & 13.6 & \multicolumn{2}{|c|}{ Average } & 11.9 & \multicolumn{2}{|c|}{ Average } & 11.6 & \multicolumn{2}{|c|}{ Average } & 9.5 \\
\hline
\end{tabular}

Table 23: Trial 4 WVP $12.5 \mathrm{~mm}$ SR and Greer W1H Initial and Final Surface Temperatures $\left({ }^{\circ} \mathrm{F}\right)$ During Polishing Procedure

\begin{tabular}{|c|c|c|c|c|c|c|c|c|c|c|c|c|c|}
\hline \multirow{3}{*}{ Polishing Position } & \multirow{3}{*}{ Specimen Number } & \multicolumn{12}{|c|}{ Surface Temperature at Each Wheel Pass Increment } \\
\hline & & \multicolumn{3}{|c|}{8000} & \multicolumn{3}{|c|}{16000} & \multicolumn{3}{|c|}{32000} & \multicolumn{3}{|c|}{48000} \\
\hline & & Initial & Final & Difference & Initial & Final & Difference & Initial & Final & Difference & Initial & Final & Difference \\
\hline 1 & $13 \mathrm{~T}$ & 75 & 89 & 14 & 78.2 & 89.2 & 11 & 76.8 & 90.6 & 13.8 & 77.7 & 89.2 & 11.5 \\
\hline 2 & $15 \mathrm{~T}$ & 75 & 88.3 & 13.3 & 78.2 & 88.5 & 10.3 & 76.4 & 90.3 & 13.9 & 77.7 & 89.6 & 11.9 \\
\hline 3 & $14 \mathrm{~T}$ & 75.3 & 87.4 & 12.1 & 78.2 & 88.5 & 10.3 & 76.4 & 91 & 14.6 & 77.7 & 87 & 9.3 \\
\hline 4 & $16 \mathrm{~T}$ & 75 & 89 & 14 & 78.4 & 89.6 & 11.2 & 77 & 90.3 & 13.3 & 78 & 89.2 & 11.2 \\
\hline 5 & $24 \mathrm{~T}$ & 75.4 & 87 & 11.6 & 78.8 & 88.5 & 9.7 & 76.6 & 88.1 & 11.5 & 77.7 & 88.1 & 10.4 \\
\hline 6 & $18 \mathrm{~T}$ & 74.4 & 88.1 & 13.7 & 78.4 & 88.7 & 10.3 & 76.2 & 90.1 & 13.9 & 77.7 & 87 & 9.3 \\
\hline 7 & $21 \mathrm{~T}$ & 74.4 & 87.6 & 13.2 & 78 & 88.3 & 10.3 & 76.2 & 89.4 & 13.2 & 77.7 & 87.9 & 10.2 \\
\hline 8 & $23 \mathrm{~T}$ & 75 & 86.7 & 11.7 & 78.4 & 87.4 & 9 & 75.9 & 88.5 & 12.6 & 77.7 & 87.4 & 9.7 \\
\hline 9 & $19 \mathrm{~T}$ & 74.4 & 86.9 & 12.5 & 78.2 & 87.4 & 9.2 & 76.8 & 90.1 & 13.3 & 77.7 & 86.9 & 9.2 \\
\hline 10 & $22 \mathrm{~T}$ & 74.4 & 88.5 & 14.1 & 78.2 & 88.3 & 10.1 & 76.4 & 89.4 & 13 & 77.7 & 87 & 9.3 \\
\hline 11 & $20 \mathrm{~T}$ & 75.3 & 87.8 & 12.5 & 78.2 & 87.4 & 9.2 & 76.4 & 87.8 & 11.4 & 77.7 & 88.1 & 10.4 \\
\hline 12 & $17 \mathrm{~T}$ & 74.4 & 86.9 & 12.5 & 78.6 & 87.9 & 9.3 & 76.4 & 91 & 14.6 & 77.7 & 87.2 & 9.5 \\
\hline & & \multicolumn{2}{|c|}{ Average } & 12.9 & \multicolumn{2}{|c|}{ Average } & 10.0 & \multicolumn{2}{|c|}{ Average } & 13.3 & \multicolumn{2}{|c|}{ Average } & 10.2 \\
\hline
\end{tabular}


Table 24: Trial 5 WVP 12.5mm SR and Greer W1H Initial and Final Surface Temperatures ( $\left.{ }^{\circ} \mathrm{F}\right)$ During Polishing Procedure

\begin{tabular}{|c|c|c|c|c|c|c|c|c|c|c|c|c|c|c|c|c|}
\hline \multirow{3}{*}{ Polishing Position } & \multirow{3}{*}{ Specimen Number } & \multicolumn{15}{|c|}{ Surface Temperature at Each Wheel Pass Increment } \\
\hline & & \multicolumn{3}{|c|}{8000} & \multicolumn{3}{|c|}{16000} & \multicolumn{3}{|c|}{32000} & \multicolumn{3}{|c|}{48000} & \multicolumn{3}{|c|}{64000} \\
\hline & & Initial & Final & Difference & Initial & Final & Difference & Initial & Final & Difference & Initial & Final & Difference & Initial & Final & Difference \\
\hline 1 & 13B & 75 & 83.6 & 8.6 & 78.2 & 84.5 & 6.3 & 75.9 & 85.4 & 9.5 & 78.6 & 85.8 & 7.2 & 75.3 & 84 & 8.7 \\
\hline 2 & $15 \mathrm{~B}$ & 75 & 83.3 & 8.3 & 78.2 & 83.8 & 5.6 & 75.5 & 85.4 & 9.9 & 78.2 & 86.1 & 7.9 & 75.3 & 84 & 8.7 \\
\hline 3 & $14 \mathrm{~B}$ & 75 & 82.5 & 7.5 & 78.2 & 83.6 & 5.4 & 76.2 & 83.4 & 7.2 & 77.9 & 86.9 & 9 & 76.2 & 83.8 & 7.6 \\
\hline 4 & $16 \mathrm{~B}$ & 75 & 82.2 & 7.2 & 78.6 & 85.2 & 6.6 & 76.6 & 84.5 & 7.9 & 78.2 & 86.1 & 7.9 & 75.7 & 83.4 & 7.7 \\
\hline 5 & $24 \mathrm{~B}$ & 75.3 & 81.8 & 6.5 & 78.2 & 83.8 & 5.6 & 76.2 & 84.2 & 8 & 78.8 & 86 & 7.2 & 75.9 & 83.5 & 7.6 \\
\hline 6 & $18 \mathrm{~B}$ & 74.8 & 82.9 & 8.1 & 78.2 & 84.5 & 6.3 & 75.9 & 83.3 & 7.4 & 78.8 & 86 & 7.2 & 75.9 & 83.8 & 7.9 \\
\hline 7 & $21 \mathrm{~B}$ & 75.3 & 82.2 & 6.9 & 78.4 & 84.5 & 6.1 & 76.2 & 84.2 & 8 & 78.4 & 86.3 & 7.9 & 76.2 & 83.8 & 7.6 \\
\hline 8 & $23 \mathrm{~B}$ & 75.3 & 82.2 & 6.9 & 78 & 84.3 & 6.3 & 75.9 & 84.2 & 8.3 & 78.8 & 85.2 & 6.4 & 76.1 & 84 & 7.9 \\
\hline 9 & $19 \mathrm{~B}$ & 74.8 & 82.5 & 7.7 & 78.6 & 84.5 & 5.9 & 76.2 & 83.3 & 7.1 & 78.6 & 86 & 7.4 & 76.2 & 83.6 & 7.4 \\
\hline 10 & $22 \mathrm{~B}$ & 75 & 82.2 & 7.2 & 77.5 & 84 & 6.5 & 75.9 & 84.5 & 8.6 & 78.2 & 86 & 7.8 & 76.2 & 83.6 & 7.4 \\
\hline 11 & $20 \mathrm{~B}$ & 75.3 & 82.9 & 7.6 & 78.2 & 83.3 & 5.1 & 75.9 & 83.8 & 7.9 & 78.9 & 85.8 & 6.9 & 76.2 & 84 & 7.8 \\
\hline 12 & $17 \mathrm{~B}$ & 74.8 & 82 & 7.2 & 78.2 & 84.7 & 6.5 & 76.6 & 84.7 & 8.1 & 78.2 & 85.8 & 7.6 & 76.6 & 84.3 & 7.7 \\
\hline & & \multicolumn{2}{|c|}{ Average } & 7.5 & \multicolumn{2}{|c|}{ Average } & 6.0 & \multicolumn{2}{|c|}{ Average } & 8.2 & \multicolumn{2}{|c|}{ Average } & 7.5 & \multicolumn{2}{|c|}{ Average } & 7.8 \\
\hline
\end{tabular}

Table 25: Trial 6 JFA 12.5mm SR and WVP W1-RAP Initial and Final Surface Temperatures ( ${ }^{\circ}$ F) During Polishing Procedure

\begin{tabular}{|c|c|c|c|c|c|c|c|c|c|c|c|c|c|}
\hline \multirow{3}{*}{ Polishing Position } & \multirow{3}{*}{ Specimen Number } & \multicolumn{12}{|c|}{ Surface Temperature at Each Wheel Pass Increment } \\
\hline & & \multicolumn{3}{|c|}{8000} & \multicolumn{3}{|c|}{16000} & \multicolumn{3}{|c|}{32000} & \multicolumn{3}{|c|}{48000} \\
\hline & & Initial & Final & Difference & Initial & Final & Difference & Initial & Final & Difference & Initial & Final & Difference \\
\hline 1 & $28 \mathrm{~B}$ & 74.3 & 79.8 & 5.5 & 75.5 & 80.4 & 4.9 & 73.4 & 82.9 & 9.5 & 71.9 & 78.9 & 7 \\
\hline 2 & $30 \mathrm{~B}$ & 73.9 & 80.9 & 7 & 74.8 & 82 & 7.2 & 74.1 & 80.4 & 6.3 & 71.6 & 79.7 & 8.1 \\
\hline 3 & $34 B$ & 74.3 & 80.2 & 5.9 & 75.2 & 81.3 & 6.1 & 74.1 & 82.2 & 8.1 & 71.9 & 79.3 & 7.4 \\
\hline 4 & $31 \mathrm{~B}$ & 73.9 & 80 & 6.1 & 75.2 & 80.4 & 5.2 & 74.8 & 82 & 7.2 & 71.6 & 78.6 & 7 \\
\hline 5 & $32 \mathrm{~B}$ & 73.9 & 80.6 & 6.7 & 74.8 & 81.6 & 6.8 & 74.4 & 82.2 & 7.8 & 71.6 & 79.3 & 7.7 \\
\hline 6 & $25 B$ & 73.9 & 80.6 & 6.7 & 74.8 & 80.9 & 6.1 & 74.4 & 82.4 & 8 & 71.9 & 79.7 & 7.8 \\
\hline 7 & $26 \mathrm{~B}$ & 74.6 & 80.9 & 6.3 & 74.8 & 81.1 & 6.3 & 74.8 & 82.7 & 7.9 & 71.9 & 79.3 & 7.4 \\
\hline 8 & $35 \mathrm{~B}$ & 73.9 & 80.6 & 6.7 & 74.4 & 81.6 & 7.2 & 74.1 & 82.9 & 8.8 & 71.6 & 79.1 & 7.5 \\
\hline 9 & $33 \mathrm{~B}$ & 73.9 & 80.2 & 6.3 & 74.8 & 80.9 & 6.1 & 74.8 & 82.4 & 7.6 & 71.9 & 79.1 & 7.2 \\
\hline 10 & $36 \mathrm{~B}$ & 73.9 & 80.9 & 7 & 75.2 & 81.6 & 6.4 & 74.1 & 82.9 & 8.8 & 72.3 & 79.5 & 7.2 \\
\hline 11 & $29 B$ & 73.9 & 80.6 & 6.7 & 74.4 & 80.2 & 5.8 & 74.8 & 82.7 & 7.9 & 71.9 & 79.9 & 8 \\
\hline 12 & $27 \mathrm{~B}$ & 74.3 & 80.2 & 5.9 & 75.2 & 80.9 & 5.7 & 74.1 & 82.2 & 8.1 & 71.9 & 79.1 & 7.2 \\
\hline & & \multicolumn{2}{|c|}{ Average } & 6.4 & \multicolumn{2}{|c|}{ Average } & 6.2 & \multicolumn{2}{|c|}{ Average } & 8.0 & \multicolumn{2}{|c|}{ Average } & 7.5 \\
\hline
\end{tabular}


Table 26: Trial 7 JFA 12.5mm SR and WVP W1-RAP Initial and Final Surface Temperatures $\left({ }^{\circ}\right.$ F) During Polishing Procedure

\begin{tabular}{|c|c|c|c|c|c|c|c|c|c|c|c|c|c|}
\hline \multirow{3}{*}{ Polishing Position } & \multirow{3}{*}{ Specimen Number } & \multicolumn{12}{|c|}{ Surface Temperature at Each Wheel Pass Increment } \\
\hline & & \multicolumn{3}{|c|}{8000} & \multicolumn{3}{|c|}{16000} & \multicolumn{3}{|c|}{32000} & \multicolumn{3}{|c|}{48000} \\
\hline & & Initial & Final & Difference & Initial & Final & Difference & Initial & Final & Difference & Initial & Final & Difference \\
\hline 1 & $28 \mathrm{~T}$ & 76.6 & 87.4 & 10.8 & 78.4 & 87.6 & 9.2 & 77.3 & 89.6 & 12.3 & 77.3 & 89.6 & 12.3 \\
\hline 2 & $30 \mathrm{~T}$ & 76.2 & 87.2 & 11 & 77.7 & 88.7 & 11 & 77.1 & 90.6 & 13.5 & 77.3 & 82.6 & 5.3 \\
\hline 3 & $34 \mathrm{~T}$ & 76.2 & 88.5 & 12.3 & 78.4 & 88.8 & 10.4 & 76.8 & 90.3 & 13.5 & 77.3 & 89.4 & 12.1 \\
\hline 4 & $31 \mathrm{~T}$ & 76.6 & 86 & 9.4 & 78.4 & 87.8 & 9.4 & 77.5 & 90.3 & 12.8 & 77.3 & 89.4 & 12.1 \\
\hline 5 & $32 \mathrm{~T}$ & 77 & 87.8 & 10.8 & 78 & 88.5 & 10.5 & 77.5 & 90.38 & 12.88 & 77 & 88.1 & 11.1 \\
\hline 6 & $25 \mathrm{~T}$ & 77 & 87.8 & 10.8 & 78 & 87.6 & 9.6 & 77.9 & 89.4 & 11.5 & 77.3 & 88 & 10.7 \\
\hline 7 & $26 \mathrm{~T}$ & 77 & 87.8 & 10.8 & 78 & 88.1 & 10.1 & 77.1 & 90.6 & 13.5 & 77.3 & 89.4 & 12.1 \\
\hline 8 & $35 \mathrm{~T}$ & 76.2 & 87.2 & 11 & 77.7 & 87.6 & 9.9 & 77.1 & 91.4 & 14.3 & 77.3 & 88.3 & 11 \\
\hline 9 & $33 \mathrm{~T}$ & 75.9 & 87.2 & 11.3 & 78 & 87.9 & 9.9 & 77.5 & 90.6 & 13.1 & 77.3 & 89.6 & 12.3 \\
\hline 10 & $36 \mathrm{~T}$ & 76.2 & 87.2 & 11 & 77.7 & 86.9 & 9.2 & 77.1 & 89.7 & 12.6 & 76.6 & 89.2 & 12.6 \\
\hline 11 & $29 \mathrm{~T}$ & 76.6 & 87.9 & 11.3 & 77.7 & 88.3 & 10.6 & 76.8 & 91.7 & 14.9 & 77.7 & 87.9 & 10.2 \\
\hline 12 & $27 \mathrm{~T}$ & 76.2 & 87.2 & 11 & 78 & 88.3 & 10.3 & 77.3 & 90.3 & 13 & 77.3 & 89.2 & 11.9 \\
\hline & & \multicolumn{2}{|c|}{ Average } & 11.0 & \multicolumn{2}{|c|}{ Average } & 10.0 & \multicolumn{2}{|c|}{ Average } & 13.2 & \multicolumn{2}{|c|}{ Average } & 11.1 \\
\hline
\end{tabular}


Table 27: Trial 8 JFA 12.5mm SR Laboratory Compacted and Field Core Initial and Final Surface Temperatures $\left({ }^{\circ} \mathrm{F}\right)$ During Polishing Procedure

\begin{tabular}{|c|c|c|c|c|c|c|c|c|c|c|}
\hline \multirow{3}{*}{ Polishing Position } & \multirow{3}{*}{ Specimen Number } & \multicolumn{9}{|c|}{ Surface Temperature at Each Wheel Pass Increment } \\
\hline & & \multicolumn{3}{|c|}{8000} & \multicolumn{3}{|c|}{24000} & \multicolumn{3}{|c|}{48000} \\
\hline & & Initial & Final & Difference & Initial & Final & Difference & Initial & Final & Difference \\
\hline 1 & $1 \mathrm{~F}$ & 76.8 & 87.4 & 10.6 & 76.1 & 88.5 & 12.4 & 76.2 & 89.9 & 13.7 \\
\hline 2 & $3 \mathrm{~L}$ & 76.8 & 86.9 & 10.1 & 75.7 & 87.6 & 11.9 & 75.9 & 89.6 & 13.7 \\
\hline 3 & $6 \mathrm{~F}$ & 76.8 & 86.9 & 10.1 & 75.3 & 88.5 & 13.2 & 75.9 & 88.5 & 12.6 \\
\hline 4 & $5 \mathrm{~F}$ & 76.6 & 87 & 10.4 & 76.1 & 87.8 & 11.7 & 75.9 & 89.6 & 13.7 \\
\hline 5 & $1 \mathrm{~L}$ & 77 & 86.9 & 9.9 & 76.1 & 88.1 & 12 & 76.2 & 89.2 & 13 \\
\hline 6 & $2 \mathrm{~F}$ & 76.6 & 86.5 & 9.9 & 76.1 & 88.5 & 12.4 & 75.9 & 88.7 & 12.8 \\
\hline 7 & $6 \mathrm{~L}$ & 76.2 & 86.9 & 10.7 & 76.1 & 87.8 & 11.7 & 75.9 & 89.2 & 13.3 \\
\hline 8 & $4 \mathrm{~F}$ & 76.2 & 88.1 & 11.9 & 75.7 & 88.8 & 13.1 & 75.5 & 89.6 & 14.1 \\
\hline 9 & $2 \mathrm{~L}$ & 76.8 & 87.4 & 10.6 & 75 & 88.3 & 13.3 & 75.5 & 88.7 & 13.2 \\
\hline 10 & $4 \mathrm{~L}$ & 76.8 & 86.5 & 9.7 & 75.3 & 87.8 & 12.5 & 75.9 & 88.8 & 12.9 \\
\hline 11 & $5 \mathrm{~L}$ & 76.1 & 87 & 10.9 & 75.7 & 87.9 & 12.2 & 75.9 & 89.4 & 13.5 \\
\hline 12 & $3 \mathrm{~F}$ & 76.4 & 87 & 10.6 & 75.7 & 88.3 & 12.6 & 75.5 & 88.3 & 12.8 \\
\hline & & \multicolumn{2}{|c|}{ Average } & 10.5 & \multicolumn{2}{|c|}{ Average } & 12.4 & \multicolumn{2}{|c|}{ Average } & 13.3 \\
\hline
\end{tabular}

Table 28: Trial 9 JFA 12.5mm SR I-79 Field Core Initial and Final Surface Temperatures $\left({ }^{\circ} \mathrm{F}\right)$ During Polishing Procedure

\begin{tabular}{|c|c|c|c|c|c|c|c|c|c|c|}
\hline \multirow{3}{*}{ Polishing Position } & \multirow{3}{*}{ Specimen Number } & \multicolumn{9}{|c|}{ Surface Temperature at Each Wheel Pass Increment } \\
\hline & & \multicolumn{3}{|c|}{8000} & \multicolumn{3}{|c|}{24000} & \multicolumn{3}{|c|}{48000} \\
\hline & & Initial & Final & Difference & Initial & Final & Difference & Initial & Final & Difference \\
\hline 3 & D4 & 75.3 & 87.2 & 11.9 & 76.6 & 90.3 & 13.7 & 77.7 & 90.1 & 12.4 \\
\hline 5 & D1 & 75.5 & 86.7 & 11.2 & 76.6 & 89.6 & 13 & 77.7 & 90.5 & 12.8 \\
\hline 7 & D3 & 75.3 & 86.9 & 11.6 & 76.8 & 92.4 & 15.6 & 78.4 & 91.7 & 13.3 \\
\hline 8 & D2 & 75.3 & 86.3 & 11 & 75.9 & 89.6 & 13.7 & 78.4 & 90.1 & 11.7 \\
\hline 9 & D5 & 75.3 & 88.5 & 13.2 & 76.6 & 91.4 & 14.8 & 78 & 89.7 & 11.7 \\
\hline & & \multicolumn{2}{|c|}{ Average } & 11.8 & \multicolumn{2}{|c|}{ Average } & 14.2 & \multicolumn{2}{|c|}{ Average } & 12.4 \\
\hline
\end{tabular}




\section{Tire Surface Temperature}

Table 29: Trial 2 JFA 12.5mm SR and WVP W1-RAP Initial and Final Tire Surface Temperatures $\left({ }^{\circ}\right.$ F) During Polishing Procedure

\begin{tabular}{|c|c|c|c|c|c|c|c|c|c|c|c|c|c|c|c|c|c|}
\hline \multirow{3}{*}{ Tire } & \multicolumn{17}{|c|}{ Surface Temperature at Each Wheel Pass Increment } \\
\hline & \multicolumn{3}{|c|}{8000} & \multicolumn{3}{|c|}{16000} & \multicolumn{5}{|c|}{32000} & \multicolumn{6}{|c|}{48000} \\
\hline & Initial & Final & Difference & Initial & Final & Difference & Initial & Final (Sidewall) & Difference & Tread & Difference & \begin{tabular}{|l|} 
Initial (Sidewall) \\
\end{tabular} & \begin{tabular}{|l|} 
Final (Sidewall) \\
\end{tabular} & Difference & Initial (Tread) & Final (Tread) & Difference \\
\hline 1 & 77.9 & 82.2 & 4.3 & 75.2 & 78.8 & 3.6 & 75.5 & 78.9 & 3.4 & 83.1 & 7.6 & 76.1 & 77.3 & 1.2 & 76.1 & 80 & 3.9 \\
\hline 2 & 78.2 & 81.8 & 3.6 & 75.2 & 79.1 & 3.9 & 75.5 & 79.7 & 4.2 & 83.6 & 8.1 & 75 & 78.2 & 3.2 & 75.3 & 80 & 4.7 \\
\hline 3 & 78.6 & 83.3 & 4.7 & 75.9 & 79.5 & 3.6 & 75.9 & 79.3 & 3.4 & 84 & 8.1 & 74.3 & 78 & 3.7 & 74.8 & 80.4 & 5.6 \\
\hline 4 & 77.9 & 81.8 & 3.9 & 75.9 & 78.2 & 2.3 & 75.3 & 78.9 & 3.6 & 82.2 & 6.9 & 74.1 & 77.3 & 3.2 & 74.1 & 78.9 & 4.8 \\
\hline & \multicolumn{2}{|c|}{ Arerage } & 4.1 & \multicolumn{2}{|c|}{ Average } & 3.3 & & Average & 3.7 & \begin{tabular}{|l|} 
Average \\
\end{tabular} & 7.7 & \multicolumn{2}{|c|}{ Average } & 2.8 & \multicolumn{2}{|c|}{ Average } & 4.8 \\
\hline
\end{tabular}

Table 30: Trial 3 JFA 12.5mm SR and WVP W1-RAP Initial and Final Tire Surface Temperatures $\left({ }^{\circ}\right.$ F) During Polishing Procedure

\begin{tabular}{|c|c|c|c|c|c|c|c|c|c|c|c|c|c|c|c|c|c|c|}
\hline \multirow{3}{*}{ Tire } & \multicolumn{18}{|c|}{ Surface Temperature of Sidewall at Each Wheel Pass Increment } \\
\hline & \multicolumn{3}{|c|}{8000} & \multicolumn{3}{|c|}{16000} & \multicolumn{3}{|c|}{32000} & \multicolumn{3}{|c|}{48000} & \multicolumn{3}{|c|}{64000} & \multicolumn{3}{|c|}{80000} \\
\hline & Initial & Final & Difference & Initial & Final & Difference & Initial & Final & Difference & Initial & Final & Difference & Initial & Final & Difference & Initial & Final & Difference \\
\hline 1 & 76.2 & 80.6 & 4.4 & 76.1 & 81.1 & 5 & 74.1 & 80.2 & 6.1 & 75.3 & 82.5 & 7.2 & 75.3 & 82 & 6.7 & 75.7 & 80.2 & 4.5 \\
\hline 2 & 75.9 & 82.4 & 6.5 & 76.8 & 82.5 & 5.7 & 74.1 & 83.4 & 9.3 & 75.7 & 82.9 & 7.2 & 75 & 83.6 & 8.6 & 75.7 & 81.6 & 5.9 \\
\hline 3 & 75.9 & 81.3 & 5.4 & 76.4 & 81.8 & 5.4 & 73.7 & 80.6 & 6.9 & 75.7 & 82.2 & 6.5 & 75 & 81.1 & 6.1 & 76.1 & 82.4 & 6.3 \\
\hline \multirow[t]{2}{*}{4} & 76.6 & 83.1 & 6.5 & 76.1 & 83.4 & 7.3 & 74.4 & 83.3 & 8.9 & 75.7 & 83.6 & 7.9 & 75.7 & 84.2 & 8.5 & 75.3 & 82 & 6.7 \\
\hline & \multicolumn{2}{|c|}{ Average } & 5.7 & \multicolumn{2}{|c|}{ Average } & 5.9 & & rage & 7.8 & \multicolumn{2}{|c|}{ Average } & 7.2 & \multicolumn{2}{|c|}{ Average } & 7.5 & \multicolumn{2}{|c|}{ Average } & 5.9 \\
\hline
\end{tabular}

\begin{tabular}{|c|c|c|c|c|c|c|c|c|c|c|c|c|c|c|c|c|c|c|}
\hline \multirow{3}{*}{ Tire } & \multicolumn{18}{|c|}{ Surface Temperature of Tread at Each Wheel Pass Increment } \\
\hline & \multicolumn{3}{|c|}{8000} & \multicolumn{3}{|c|}{16000} & \multicolumn{3}{|c|}{32000} & \multicolumn{3}{|c|}{48000} & \multicolumn{3}{|c|}{64000} & \multicolumn{3}{|c|}{80000} \\
\hline & Initial & Final & Difference & Initial & Final & Difference & Initial & Final & \begin{tabular}{|l|} 
Difference \\
\end{tabular} & Initial & Final & Difference & Initial & Final & Difference & Initial & Final & Difference \\
\hline 1 & 76.2 & 85.8 & 9.6 & 76.4 & 84.9 & 8.5 & 74.1 & 84 & 9.9 & 75.7 & 86.9 & 11.2 & 75 & 86.1 & 11.1 & 75.7 & 83.1 & 7.4 \\
\hline 2 & 76.6 & 89.6 & 13 & 76.4 & 88.7 & 12.3 & 74.4 & 88.7 & 14.3 & 75.3 & 88.7 & 13.4 & 74.8 & 87 & 12.2 & 76.4 & 84.7 & 8.3 \\
\hline 3 & 76.2 & 82.7 & 6.5 & 76.4 & 84.5 & 8.1 & 74.1 & 84.3 & 10.2 & 75.3 & 85.2 & 9.9 & 75.3 & 83.8 & 8.5 & 75.7 & 83.1 & 7.4 \\
\hline \multirow[t]{2}{*}{4} & 76.6 & 88.5 & 11.9 & 76.1 & 89.4 & 13.3 & 74.1 & 88.1 & 14 & 76.1 & 88.7 & 12.6 & 75.3 & 86.9 & 11.6 & 75 & 85.1 & 10.1 \\
\hline & \multicolumn{2}{|c|}{ Average } & 10.3 & \multicolumn{2}{|c|}{ Average } & 10.6 & & rage & 12.1 & \multicolumn{2}{|c|}{ Average } & 11.8 & \multicolumn{2}{|c|}{ Average } & 10.9 & \multicolumn{2}{|c|}{ Average } & 8.3 \\
\hline
\end{tabular}


Table 31: Trial 4 WVP 12.5mm SR and Greer W1H Initial and Final Tire Surface Temperatures $\left({ }^{\circ}\right.$ F) During Polishing Procedure

\begin{tabular}{|c|c|c|c|c|c|c|c|c|c|c|c|c|}
\hline \multirow{3}{*}{ Tire } & \multicolumn{12}{|c|}{ Surface Temperature of Tread at Each Wheel Pass Increment } \\
\hline & \multicolumn{3}{|c|}{8000} & \multicolumn{3}{|c|}{16000} & \multicolumn{3}{|c|}{32000} & \multicolumn{3}{|c|}{48000} \\
\hline & Initial & Final & Difference & Initial & Final & Difference & Initial & Final & Difference & Initial & Final & Difference \\
\hline 1 & 77.1 & 88.3 & 11.2 & 77.9 & 89.0 & 11.1 & 76.8 & 89.0 & 12.2 & 77.3 & 85.6 & 8.3 \\
\hline 2 & 77.9 & 93.0 & 15.1 & 77.5 & 93.5 & 16.0 & 77.1 & 93.7 & 16.6 & 77.3 & 91.4 & 14.1 \\
\hline 3 & 77.5 & 89.4 & 11.9 & 78.4 & 89.6 & 11.2 & 77.1 & 89.2 & 12.1 & 77.7 & 87.6 & 9.9 \\
\hline \multirow[t]{2}{*}{4} & 77.1 & 92.3 & 15.2 & 78.0 & 91.9 & 13.9 & 76.6 & 91.5 & 14.9 & 77.3 & 89.2 & 11.9 \\
\hline & \multicolumn{2}{|c|}{ Average } & 13.4 & \multicolumn{2}{|c|}{ Average } & 13.1 & \multicolumn{2}{|c|}{ Average } & 14.0 & \multicolumn{2}{|c|}{ Average } & 11.1 \\
\hline
\end{tabular}

\begin{tabular}{|c|c|c|c|c|c|c|c|c|c|c|c|c|}
\hline \multirow{3}{*}{ Tire } & \multicolumn{12}{|c|}{ Surface Temperature of Sidewall at Each Wheel Pass Increment } \\
\hline & \multicolumn{3}{|c|}{8000} & \multicolumn{3}{|c|}{16000} & \multicolumn{3}{|c|}{32000} & \multicolumn{3}{|c|}{48000} \\
\hline & Initial & Final & Difference & Initial & Final & Difference & Initial & Final & Difference & Initial & Final & Difference \\
\hline 1 & 77.9 & 81.8 & 3.9 & 77.9 & 81.8 & 3.9 & 76.8 & 84.9 & 8.1 & 77.3 & 82.4 & 5.1 \\
\hline 2 & 77.5 & 85.4 & 7.9 & 77.3 & 84.0 & 6.7 & 76.8 & 86.1 & 9.3 & 77.7 & 84.9 & 7.2 \\
\hline 3 & 77.9 & 83.3 & 5.4 & 78.0 & 82.0 & 4.0 & 76.4 & 83.3 & 6.9 & 78.4 & 84.2 & 5.8 \\
\hline \multirow[t]{2}{*}{4} & 77.1 & 85.2 & 8.1 & 78.8 & 83.4 & 4.6 & 76.2 & 85.6 & 9.4 & 77.3 & 84.5 & 7.2 \\
\hline & \multicolumn{2}{|c|}{ Average } & 6.3 & \multicolumn{2}{|c|}{ Average } & 4.8 & \multicolumn{2}{|c|}{ Average } & 8.4 & \multicolumn{2}{|c|}{ Average } & 6.3 \\
\hline
\end{tabular}


Table 32: Trial 5 WVP 12.5mm SR and Greer W1H Initial and Final Tire Surface Temperatures $\left({ }^{\circ} \mathrm{F}\right)$ During Polishing Procedure

\begin{tabular}{|c|c|c|c|c|c|c|c|c|c|c|c|c|c|c|c|}
\hline \multirow{3}{*}{ Tire } & \multicolumn{15}{|c|}{ Surface Temperature of Tread at Each Wheel Pass Increment } \\
\hline & \multicolumn{3}{|c|}{8000} & \multicolumn{3}{|c|}{16000} & \multicolumn{3}{|c|}{32000} & \multicolumn{3}{|c|}{48000} & \multicolumn{3}{|c|}{64000} \\
\hline & Initial & Final & Difference & Initial & Final & Difference & Initial & Final & Difference & Initial & Final & Difference & Initial & Final & Difference \\
\hline 1 & 76.4 & 85.6 & 9.2 & 77.9 & 85.8 & 7.9 & 76.6 & 85.4 & 8.8 & 77.9 & 87.2 & 9.3 & 78 & 84.7 & 6.7 \\
\hline 2 & 77.1 & 87.2 & 10.1 & 77.9 & 88.5 & 10.6 & 77 & 87.8 & 10.8 & 78.6 & 89.4 & 10.8 & 78.8 & 85.8 & 7 \\
\hline 3 & 77.1 & 84.9 & 7.8 & 77.5 & 86.3 & 8.8 & 76.6 & 85.8 & 9.2 & 78.6 & 86.7 & 8.1 & 78 & 84.2 & 6.2 \\
\hline \multirow[t]{2}{*}{4} & 76.4 & 86 & 9.6 & 77.9 & 87.4 & 9.5 & 76.6 & 86.1 & 9.5 & 78.4 & 87.4 & 9 & 77.7 & 85.1 & 7.4 \\
\hline & \multicolumn{2}{|c|}{ Average } & 9.2 & \multicolumn{2}{|c|}{ Average } & 9.2 & \multicolumn{2}{|c|}{ Average } & 9.6 & \multicolumn{2}{|c|}{ Average } & 9.3 & \multicolumn{2}{|c|}{ Average } & 6.8 \\
\hline
\end{tabular}

\begin{tabular}{|c|c|c|c|c|c|c|c|c|c|c|c|c|c|c|c|}
\hline \multirow{3}{*}{ Tire } & \multicolumn{15}{|c|}{ Surface Temperature of Sidewall at Each Wheel Pass Increment } \\
\hline & \multicolumn{3}{|c|}{8000} & \multicolumn{3}{|c|}{16000} & \multicolumn{3}{|c|}{32000} & \multicolumn{3}{|c|}{48000} & \multicolumn{3}{|c|}{64000} \\
\hline & Initial & Final & Difference & Initial & Final & Difference & Initial & Final & Difference & Initial & Final & Difference & Initial & Final & Difference \\
\hline 1 & 76.4 & 80.9 & 4.5 & 77.9 & 82.4 & 4.5 & 77 & 82.2 & 5.2 & 78.2 & 83.4 & 5.2 & 77.1 & 81.3 & 4.2 \\
\hline 2 & 76.8 & 82.2 & 5.4 & 78.2 & 82.9 & 4.7 & 77 & 82.7 & 5.7 & 78.2 & 84 & 5.8 & 78 & 82.4 & 4.4 \\
\hline 3 & 76.4 & 81.5 & 5.1 & 78.2 & 82.5 & 4.3 & 77 & 81.8 & 4.8 & 78.8 & 84 & 5.2 & 77.7 & 81.5 & 3.8 \\
\hline \multirow[t]{2}{*}{4} & 76.1 & 82.5 & 6.4 & 78.2 & 82.9 & 4.7 & 76.6 & 82.4 & 5.8 & 78 & 84.2 & 6.2 & 77.7 & 82 & 4.3 \\
\hline & \multicolumn{2}{|c|}{ Average } & 5.4 & \multicolumn{2}{|c|}{ Average } & 4.6 & \multicolumn{2}{|c|}{ Average } & 5.4 & \multicolumn{2}{|c|}{ Average } & 5.6 & \multicolumn{2}{|c|}{ Average } & 4.2 \\
\hline
\end{tabular}


Table 33: Trial 6 JFA 12.5mm SR and WVP W1-RAP Initial and Final Tire Surface Temperatures $\left({ }^{\circ}\right.$ F) During Polishing Procedure

\begin{tabular}{|c|c|c|c|c|c|c|c|c|c|c|c|c|}
\hline \multirow{3}{*}{ Tire } & \multicolumn{12}{|c|}{ Surface Temperature of Tread at Each Wheel Pass Increment } \\
\hline & \multicolumn{3}{|c|}{8000} & \multicolumn{3}{|c|}{16000} & \multicolumn{3}{|c|}{32000} & \multicolumn{3}{|c|}{48000} \\
\hline & Initial & Final & Difference & Initial & Final & Difference & Initial & Final & Difference & Initial & Final & Difference \\
\hline 1 & 73.9 & 82.7 & 8.8 & 75.2 & 82.4 & 7.2 & 75.5 & 84.2 & 8.7 & 72.6 & 80.6 & 8.0 \\
\hline 2 & 73.9 & 84.7 & 10.8 & 75.2 & 85.6 & 10.4 & 75.9 & 84.3 & 8.4 & 72.6 & 81.8 & 9.2 \\
\hline 3 & 74.3 & 82.4 & 8.1 & 75.2 & 83.6 & 8.4 & 75.9 & 83.4 & 7.5 & 72.6 & 80.7 & 8.1 \\
\hline \multirow[t]{2}{*}{4} & 73.9 & 83.8 & 9.9 & 74.4 & 83.3 & 8.9 & 75.2 & 84.2 & 9.0 & 73.0 & 80.7 & 7.7 \\
\hline & \multicolumn{2}{|c|}{ Average } & 9.4 & \multicolumn{2}{|c|}{ Average } & 8.7 & \multicolumn{2}{|c|}{ Average } & 8.4 & \multicolumn{2}{|c|}{ Average } & 8.3 \\
\hline
\end{tabular}

\begin{tabular}{|c|c|c|c|c|c|c|c|c|c|c|c|c|}
\hline \multirow{3}{*}{ Tire } & \multicolumn{12}{|c|}{ Surface Temperature of Sidewall at Each Wheel Pass Increment } \\
\hline & \multicolumn{3}{|c|}{8000} & \multicolumn{3}{|c|}{16000} & \multicolumn{3}{|c|}{32000} & \multicolumn{3}{|c|}{48000} \\
\hline & Initial & Final & Difference & Initial & Final & Difference & Initial & Final & Difference & Initial & Final & Difference \\
\hline 1 & 73.9 & 77.9 & 4.0 & 75.2 & 79.7 & 4.5 & 75.2 & 78.8 & 3.6 & 72.3 & 77.0 & 4.7 \\
\hline 2 & 73.9 & 76.8 & 2.9 & 75.2 & 80.2 & 5.0 & 75.2 & 80.9 & 5.7 & 72.6 & 77.1 & 4.5 \\
\hline 3 & 74.3 & 78.2 & 3.9 & 74.8 & 79.3 & 4.5 & 74.8 & 78.4 & 3.6 & 73.0 & 76.8 & 3.8 \\
\hline \multirow[t]{2}{*}{4} & 73.9 & 78.4 & 4.5 & 74.8 & 79.8 & 5.0 & 74.8 & 79.7 & 4.9 & 72.6 & 77.7 & 5.1 \\
\hline & \multicolumn{2}{|c|}{ Average } & 3.8 & \multicolumn{2}{|c|}{ Average } & 4.8 & \multicolumn{2}{|c|}{ Average } & 4.5 & \multicolumn{2}{|c|}{ Average } & 4.5 \\
\hline
\end{tabular}


Table 34: Trial 7 JFA 12.5mm SR and WVP W1-RAP Initial and Final Tire Surface Temperatures $\left({ }^{\circ}\right.$ F) During Polishing Procedure

\begin{tabular}{|c|c|c|c|c|c|c|c|c|c|c|c|c|}
\hline \multirow{3}{*}{ Tire } & \multicolumn{12}{|c|}{ Surface Temperature of Tread at Each Wheel Pass Increment } \\
\hline & \multicolumn{3}{|c|}{8000} & \multicolumn{3}{|c|}{16000} & \multicolumn{3}{|c|}{32000} & \multicolumn{3}{|c|}{48000} \\
\hline & Initial & Final & Difference & Initial & Final & Difference & Initial & Final & Difference & Initial & Final & Difference \\
\hline 1 & 76.6 & 89.0 & 12.4 & 78.8 & 89.4 & 10.6 & 77.9 & 89.9 & 12.0 & 77.3 & 88.8 & 11.5 \\
\hline 2 & 77.0 & 94.2 & 17.2 & 78.4 & 92.4 & 14.0 & 78.2 & 92.6 & 14.4 & 77.3 & 90.5 & 13.2 \\
\hline 3 & 77.3 & 88.8 & 11.5 & 78.0 & 88.5 & 10.5 & 77.9 & 89.9 & 12.0 & 77.7 & 88.8 & 11.1 \\
\hline \multirow[t]{2}{*}{4} & 77.3 & 89.9 & 12.6 & 78.4 & 90.8 & 12.4 & 78.2 & 92.8 & 14.6 & 77.7 & 91.0 & 13.3 \\
\hline & \multicolumn{2}{|c|}{ Average } & 13.4 & \multicolumn{2}{|c|}{ Average } & 11.9 & \multicolumn{2}{|c|}{ Average } & 13.3 & \multicolumn{2}{|c|}{ Average } & 12.3 \\
\hline
\end{tabular}

\begin{tabular}{|c|c|c|c|c|c|c|c|c|c|c|c|c|}
\hline \multirow{3}{*}{ Tire } & \multicolumn{12}{|c|}{ Surface Temperature of Sidewall at Each Wheel Pass Increment } \\
\hline & \multicolumn{3}{|c|}{8000} & \multicolumn{3}{|c|}{16000} & \multicolumn{3}{|c|}{32000} & \multicolumn{3}{|c|}{48000} \\
\hline & Initial & Final & Difference & Initial & Final & Difference & Initial & Final & Difference & Initial & Final & Difference \\
\hline 1 & 77.0 & 84.0 & 7.0 & 78.4 & 84.7 & 6.3 & 77.5 & 86.5 & 9.0 & 77.0 & 85.1 & 8.1 \\
\hline 2 & 76.6 & 84.3 & 7.7 & 78.4 & 84.7 & 6.3 & 78.0 & 87.0 & 9.0 & 77.0 & 86.0 & 9.0 \\
\hline 3 & 77.0 & 83.6 & 6.6 & 78.4 & 83.4 & 5.0 & 78.2 & 84.4 & 6.2 & 77.3 & 84.7 & 7.4 \\
\hline \multirow[t]{2}{*}{4} & 77.3 & 84.7 & 7.4 & 78.0 & 86.1 & 8.1 & 78.2 & 85.1 & 6.9 & 77.7 & 85.8 & 8.1 \\
\hline & \multicolumn{2}{|c|}{ Average } & 7.2 & \multicolumn{2}{|c|}{ Average } & 6.4 & \multicolumn{2}{|c|}{ Average } & 7.8 & \multicolumn{2}{|c|}{ Average } & 8.2 \\
\hline
\end{tabular}


Table 35: Trial 8 JFA 12.5mm SR Laboratory Compacted and Field Core Initial and Final Tire Surface Temperatures $\left({ }^{\circ} \mathrm{F}\right)$ During Polishing Procedure

\begin{tabular}{|c|c|c|c|c|c|c|c|c|c|}
\hline \multirow{3}{*}{ Tire } & \multicolumn{9}{|c|}{ Surface Temperature of Tread at Each Wheel Pass Increment } \\
\hline & \multicolumn{3}{|c|}{8000} & \multicolumn{3}{|c|}{24000} & \multicolumn{3}{|c|}{48000} \\
\hline & Initial & Final & Difference & & Final & Difference & Initial & Final & Difference \\
\hline 1 & 77.5 & 87.4 & 9.9 & 76.8 & 87.2 & 10.4 & 76.6 & 87.8 & 11.2 \\
\hline 2 & 78.0 & 89.6 & 11.6 & 76.8 & 89.6 & 12.8 & 77.3 & 90.3 & 13.0 \\
\hline 3 & 77.3 & 87.4 & 10.1 & 76.4 & 87.6 & 11.2 & 77.0 & 87.6 & 10.6 \\
\hline \multirow[t]{2}{*}{4} & 78.2 & 90.3 & 12.1 & 76.4 & 89.7 & 13.3 & 77.3 & 90.6 & 13.3 \\
\hline & \multicolumn{2}{|c|}{ Average } & 10.9 & \multicolumn{2}{|c|}{ Average } & 11.9 & & ge & 12.0 \\
\hline
\end{tabular}

\begin{tabular}{|c|c|c|c|c|c|c|c|c|c|}
\hline \multirow{3}{*}{ Tire } & \multicolumn{9}{|c|}{ Surface Temperature of Sidewall at Each Wheel Pass Increment } \\
\hline & \multicolumn{3}{|c|}{8000} & \multicolumn{3}{|c|}{16000} & \multicolumn{3}{|c|}{48000} \\
\hline & Initial & Final & Difference & Initial & Final & Difference & Initial & Final & Difference \\
\hline 1 & 77.9 & 83.4 & 5.5 & 77.1 & 82.9 & 5.8 & 77.0 & 81.5 & 4.5 \\
\hline 2 & 77.3 & 83.8 & 6.5 & 76.8 & 84.7 & 7.9 & 76.6 & 84.9 & 8.3 \\
\hline 3 & 77.0 & 82.5 & 5.5 & 76.4 & 82.6 & 6.2 & 76.8 & 84.2 & 7.4 \\
\hline \multirow[t]{2}{*}{4} & 77.5 & 84.0 & 6.5 & 76.8 & 83.6 & 6.8 & 76.6 & 83.8 & 7.2 \\
\hline & \multicolumn{2}{|c|}{ Average } & 6.0 & \multicolumn{2}{|c|}{ Average } & 6.7 & \multicolumn{2}{|c|}{ Average } & 6.9 \\
\hline
\end{tabular}


Table 36: Trial 9 JFA 12.5mm SR I-79 Field Core Initial and Final Tire Surface Temperatures ( ${ }^{\circ}$ F) During Polishing Procedure

\begin{tabular}{|c|c|c|c|c|c|c|c|c|c|}
\hline \multirow{3}{*}{ Tire } & \multicolumn{9}{|c|}{ Surface Temperature of Tread at Each Wheel Pass Increment } \\
\hline & \multicolumn{3}{|c|}{8000} & \multicolumn{3}{|c|}{24000} & \multicolumn{3}{|c|}{48000} \\
\hline & Initial & Final & Difference & & Final & Difference & Initial & Final & Difference \\
\hline 1 & 75.3 & 87.8 & 12.5 & 77.0 & 89.2 & 12.2 & 77.0 & 88.7 & 11.7 \\
\hline 2 & 76.2 & 91.5 & 15.3 & 77.1 & 94.2 & 17.1 & 77.3 & 92.3 & 15.0 \\
\hline 3 & 75.7 & 88.1 & 12.4 & 77.3 & 89.6 & 12.3 & 77.7 & 88.7 & 11.0 \\
\hline \multirow[t]{2}{*}{4} & 75.7 & 91.4 & 15.7 & 77.0 & 92.4 & 15.4 & 77.7 & 90.5 & 12.8 \\
\hline & \multicolumn{2}{|c|}{ Average } & 14.0 & & & 14.3 & & age & 12.6 \\
\hline
\end{tabular}

\begin{tabular}{|c|c|c|c|c|c|c|c|c|c|}
\hline \multirow{3}{*}{ Tire } & \multicolumn{9}{|c|}{ Surface Temperature of Sidewall at Each Wheel Pass Increment } \\
\hline & \multicolumn{3}{|c|}{8000} & \multicolumn{3}{|c|}{24000} & \multicolumn{3}{|c|}{48000} \\
\hline & Initial & Final & Difference & Initial & Final & Difference & Initial & Final & Difference \\
\hline 1 & 75.3 & 83.6 & 8.3 & 77.3 & 85.1 & 7.8 & 77.0 & 83.8 & 6.8 \\
\hline 2 & 75.9 & 84.5 & 8.6 & 77.1 & 86.1 & 9.0 & 77.7 & 85.6 & 7.9 \\
\hline 3 & 75.7 & 82.4 & 6.7 & 77.0 & 84.0 & 7.0 & 76.6 & 83.3 & 6.7 \\
\hline \multirow[t]{2}{*}{4} & 75.3 & 84.3 & 9.0 & 77.0 & 86.9 & 9.9 & 78.0 & 85.6 & 7.6 \\
\hline & \multicolumn{2}{|c|}{ Average } & 8.2 & & & 8.4 & & age & 7.3 \\
\hline
\end{tabular}




\section{Tire Hardness}

Table 37: Trial 2 JFA 12.5mm SR and WVP W1-RAP Durometer Measurements During Polishing Procedure for Burris B55A Tires

\begin{tabular}{|c|c|c|c|c|c|}
\hline \multirow{2}{*}{$\begin{array}{c}\text { Number of } \\
\text { Wheel Passes }\end{array}$} & \multirow{2}{*}{ Tire } & \multicolumn{4}{|c|}{ Hardness (Durometer Reading) } \\
\cline { 2 - 6 } & & Outside Edge & Inside Edge & Center & Sidewall \\
\hline \multirow{4}{*}{0} & 1 & 85 & 85 & 79 & 70 \\
\cline { 2 - 6 } & 2 & 85 & 85 & 77 & 73 \\
\cline { 2 - 7 } & 3 & 84 & 84 & 73 & 73 \\
\cline { 2 - 7 } & 4 & 83 & 82 & 75 & 69 \\
\hline \multirow{5}{*}{32000} & 1 & 82 & 83 & 79 & 65 \\
\cline { 2 - 7 } & 2 & 80 & 81 & 80 & 70 \\
\cline { 2 - 7 } & 3 & 79 & 80 & 80 & 65 \\
\hline & 4 & 82 & 79 & 78 & 66 \\
\hline \multirow{5}{*}{48000} & 1 & 83 & 81 & 81 & 68 \\
\cline { 2 - 7 } & 2 & 82 & 82 & 80 & 67 \\
\cline { 2 - 7 } & 3 & 80 & 78 & 78 & 70 \\
\cline { 2 - 7 } & 4 & 83 & 82 & 80 & 66 \\
\hline
\end{tabular}

Table 38: Trial 3 JFA 12.5mm SR and WVP W1-RAP Durometer Measurements During Polishing Procedure for Burris B55A Tires

\begin{tabular}{|c|c|c|c|c|c|}
\hline \multirow{2}{*}{$\begin{array}{c}\text { Number of } \\
\text { Wheel Passes }\end{array}$} & \multirow{2}{*}{ Tire } & \multicolumn{4}{|c|}{ Hardness (Durometer Reading) } \\
\hline & & Outside Edge & Inside Edge & Center & Sidewall \\
\hline \multirow{4}{*}{0} & 1 & 83 & 81 & 81 & 68 \\
\hline & 2 & 82 & 82 & 80 & 67 \\
\hline & 3 & 80 & 78 & 78 & 70 \\
\hline & 4 & 83 & 82 & 80 & 66 \\
\hline \multirow{4}{*}{32000} & 1 & 81 & 81 & 81 & 66 \\
\hline & 2 & 81 & 80 & 78 & 70 \\
\hline & 3 & 79 & 79 & 76 & 74 \\
\hline & 4 & 80 & 80 & 77 & 70 \\
\hline & & & & & \\
\hline \multirow{4}{*}{48000} & 1 & 79 & 81 & 82 & 69 \\
\hline & 2 & 78 & 79 & 82 & 66 \\
\hline & 3 & 78 & 78 & 77 & 76 \\
\hline & 4 & 81 & 79 & 78 & 69 \\
\hline & & & & & \\
\hline \multirow{4}{*}{80000} & 1 & 80 & 81 & 79 & 72 \\
\hline & 2 & 80 & 78 & 81 & 71 \\
\hline & 3 & 79 & 78 & 77 & 74 \\
\hline & 4 & 81 & 79 & 80 & 68 \\
\hline
\end{tabular}


Table 39: Trial 4 WVP 12.5mm SR and Greer W1H Durometer Measurements During Polishing Procedure for Hoosier R80 Tires

\begin{tabular}{|c|c|c|c|c|c|}
\hline $\begin{array}{c}\text { Number of } \\
\text { Wheel }\end{array}$ & \multirow{2}{*}{ Tire } & \multicolumn{4}{|c|}{ Hardness (Durometer Reading) } \\
\cline { 2 - 6 } & & Outside Edge Inside Edge & Center & Sidewall \\
\hline \multirow{4}{*}{0} & 1 & 79 & 80 & 81 & 75 \\
\cline { 2 - 6 } & 2 & 78 & 79 & 79 & 74 \\
\cline { 2 - 6 } & 3 & 79 & 80 & 79 & 74 \\
\cline { 2 - 7 } & 4 & 80 & 80 & 79 & 76 \\
\hline \multirow{3}{*}{32000} & 1 & 76 & 76 & 77 & 75 \\
\cline { 2 - 7 } & 2 & 75 & 77 & 77 & 74 \\
\cline { 2 - 7 } & 3 & 76 & 75 & 78 & 74 \\
\cline { 2 - 7 } & 4 & 76 & 77 & 78 & 73 \\
\hline \multirow{5}{*}{48000} & 1 & 79 & 79 & 79 & 75 \\
\cline { 2 - 7 } & 2 & 78 & 79 & 79 & 73 \\
\cline { 2 - 7 } & 3 & 79 & 78 & 79 & 76 \\
\cline { 2 - 7 } & 4 & 79 & 79 & 79 & 74 \\
\hline
\end{tabular}

Table 40: Trial 5 WVP 12.5mm SR and Greer W1H Durometer Measurements During Polishing Procedure for Hoosier R80 Tires

\begin{tabular}{|c|c|c|c|c|c|}
\hline \multirow{2}{*}{$\begin{array}{c}\text { Number of } \\
\text { Wheel }\end{array}$} & \multirow{2}{*}{ Tire } & \multicolumn{4}{|c|}{ Hardness (Durometer Reading) } \\
\hline & & Outside Edge & Inside Edge & Center & Sidewall \\
\hline \multirow{4}{*}{0} & 1 & 79 & 79 & 79 & 75 \\
\hline & 2 & 78 & 79 & 79 & 73 \\
\hline & 3 & 79 & 78 & 79 & 76 \\
\hline & 4 & 79 & 79 & 79 & 74 \\
\hline \multirow{4}{*}{16000} & 1 & 76 & 76 & 77 & 73 \\
\hline & 2 & 76 & 77 & 78 & 72 \\
\hline & 3 & 76 & 77 & 77 & 74 \\
\hline & 4 & 76 & 77 & 78 & 74 \\
\hline \multirow{4}{*}{32000} & 1 & 77 & 78 & 79 & 72 \\
\hline & 2 & 77 & 77 & 79 & 76 \\
\hline & 3 & 77 & 77 & 78 & 72 \\
\hline & 4 & 77 & 78 & 78 & 73 \\
\hline \multirow{5}{*}{48000} & & & & & \\
\hline & 1 & 80 & 80 & 80 & 73 \\
\hline & 2 & 79 & 80 & 80 & 72 \\
\hline & 3 & 80 & 79 & 80 & 74 \\
\hline & 4 & 79 & 79 & 79 & 74 \\
\hline \multirow{4}{*}{64000} & 1 & 79 & 80 & 80 & 76 \\
\hline & 2 & 79 & 79 & 80 & 75 \\
\hline & 3 & 79 & 79 & 79 & 76 \\
\hline & 4 & 79 & 80 & 80 & 76 \\
\hline
\end{tabular}


Table 41: Trial 6 JFA 12.5mm SR and WVP W1-RAP Durometer Measurements During Polishing Procedure for Hoosier R80 Tires

\begin{tabular}{|c|c|c|c|c|c|}
\hline \multirow{2}{*}{$\begin{array}{c}\text { Number of } \\
\text { Wheel Passes }\end{array}$} & \multirow{2}{*}{ Tire } & \multicolumn{4}{|c|}{ Hardness (Durometer Reading) } \\
\hline & & Outside Edge & Inside Edge & Center & Sidewall \\
\hline \multirow{4}{*}{0} & 1 & 79 & 80 & 80 & 76 \\
\hline & 2 & 79 & 79 & 80 & 75 \\
\hline & 3 & 79 & 79 & 79 & 76 \\
\hline & 4 & 79 & 80 & 80 & 76 \\
\hline \multirow{5}{*}{16000} & & & & & \\
\hline & 1 & 79 & 81 & 80 & 78 \\
\hline & 2 & 80 & 79 & 79 & 76 \\
\hline & 3 & 81 & 81 & 81 & 77 \\
\hline & 4 & 81 & 80 & 81 & 79 \\
\hline & & & & & \\
\hline \multirow{4}{*}{32000} & 1 & 81 & 82 & 81 & 77 \\
\hline & 2 & 81 & 80 & 81 & 79 \\
\hline & 3 & 81 & 80 & 81 & 79 \\
\hline & 4 & 80 & 82 & 82 & 80 \\
\hline & & & & & \\
\hline \multirow{4}{*}{48000} & 1 & 81 & 81 & 81 & 77 \\
\hline & 2 & 80 & 82 & 80 & 77 \\
\hline & 3 & 81 & 81 & 81 & 78 \\
\hline & 4 & 80 & 81 & 81 & 78 \\
\hline
\end{tabular}

Table 42: Trial 7 JFA 12.5mm SR and WVP W1-RAP Durometer Measurements During Polishing Procedure for Hoosier R80 Tires

\begin{tabular}{|c|c|c|c|c|c|}
\hline \multirow{2}{*}{$\begin{array}{c}\text { Number of } \\
\text { Wheel Passes }\end{array}$} & \multirow{2}{*}{ Tire } & \multicolumn{4}{|c|}{ Hardness (Durometer Reading) } \\
\hline & & Outside Edge & Inside Edge & Center & Sidewall \\
\hline \multirow{4}{*}{0} & 1 & 81 & 81 & 81 & 77 \\
\hline & 2 & 80 & 82 & 80 & 77 \\
\hline & 3 & 81 & 81 & 81 & 78 \\
\hline & 4 & 80 & 81 & 81 & 78 \\
\hline \multirow{4}{*}{16000} & 1 & 79 & 78 & 80 & 79 \\
\hline & 2 & 80 & 80 & 81 & 79 \\
\hline & 3 & 80 & 82 & 80 & 80 \\
\hline & 4 & 79 & 79 & 81 & 78 \\
\hline \multirow{4}{*}{32000} & 1 & 79 & 79 & 79 & 78 \\
\hline & 2 & 78 & 81 & 79 & 80 \\
\hline & 3 & 80 & 79 & 80 & 78 \\
\hline & 4 & 79 & 79 & 80 & 78 \\
\hline \multirow{4}{*}{48000} & 1 & 81 & 80 & 80 & 78 \\
\hline & 2 & 80 & 80 & 80 & 80 \\
\hline & 3 & 79 & 79 & 80 & 80 \\
\hline & 4 & 79 & 80 & 80 & 79 \\
\hline
\end{tabular}


Table 43: Trial 8 JFA 12.5mm SR Laboratory and Field Core Durometer Measurements During Polishing Procedure for Hoosier R80 Tires

\begin{tabular}{|c|c|c|c|c|c|}
\hline \multirow{2}{*}{$\begin{array}{c}\text { Number of } \\
\text { Wheel Passes }\end{array}$} & \multirow{2}{*}{ Tire } & \multicolumn{4}{|c|}{ Hardness (Durometer Reading) } \\
\hline & & Outside Edge & Inside Edge & Center & Sidewall \\
\hline \multirow{4}{*}{ 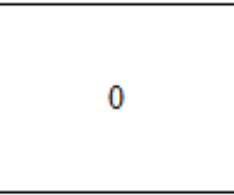 } & 1 & 81 & 80 & 80 & 78 \\
\hline & 2 & 80 & 80 & 80 & 80 \\
\hline & 3 & 79 & 79 & 80 & 80 \\
\hline & 4 & 79 & 80 & 80 & 79 \\
\hline \multirow{4}{*}{24000} & 1 & 79 & 81 & 79 & 77 \\
\hline & 2 & 80 & 81 & 80 & 78 \\
\hline & 3 & 78 & 79 & 81 & 79 \\
\hline & 4 & 80 & 81 & 79 & 78 \\
\hline \multirow{4}{*}{48000} & 1 & 80 & 79 & 81 & 80 \\
\hline & 2 & 80 & 81 & 81 & 78 \\
\hline & 3 & 81 & 79 & 80 & 78 \\
\hline & 4 & 79 & 81 & 81 & 80 \\
\hline
\end{tabular}

Table 44: Trial 9 JFA 12.5mm SR I-79 Field Core Durometer Measurements During Polishing Procedure for Hoosier R80 Tires

\begin{tabular}{|c|c|c|c|c|c|}
\hline $\begin{array}{c}\text { Number of } \\
\text { Wheel Passes }\end{array}$ & \multirow{2}{*}{ Tire } & \multicolumn{3}{|c|}{ Hardness (Durometer Reading) } \\
\cline { 2 - 6 } & & Outside Edge & Inside Edge & Center & Sidewall \\
\hline \multirow{4}{*}{0} & 1 & 80 & 79 & 81 & 80 \\
\cline { 2 - 6 } & 2 & 80 & 81 & 81 & 78 \\
\cline { 2 - 6 } & 3 & 81 & 79 & 80 & 78 \\
\cline { 2 - 6 } & 4 & 79 & 81 & 81 & 80 \\
\hline \multicolumn{5}{|c|}{} \\
\hline \multirow{4}{*}{24000} & 1 & 78 & 81 & 80 & 78 \\
\cline { 2 - 6 } & 2 & 81 & 80 & 81 & 78 \\
\cline { 2 - 6 } & 3 & 80 & 79 & 78 & 80 \\
\cline { 2 - 6 } & 4 & 80 & 80 & 81 & 81 \\
\hline \multirow{4}{*}{48000} & 1 & 80 & 79 & 81 & 80 \\
\cline { 2 - 6 } & 2 & 80 & 81 & 80 & 79 \\
\cline { 2 - 6 } & 3 & 81 & 80 & 81 & 79 \\
\cline { 2 - 6 } & 4 & 80 & 81 & 80 & 80 \\
\hline
\end{tabular}




\section{Appendix D: Raw Recorded BPN Measurements}

\section{Trial 1: WVDOH Specimens (Unknown Mixture)}

Table 45: BPN Measurements for Trial 1 WVDOH Specimens (Unknown Mixture) Polished with Burris B44A Tires at Low Toe for 160,000 Wheel Passes

\begin{tabular}{|c|c|c|c|c|c|c|c|}
\hline \multirow[b]{2}{*}{$\begin{array}{c}\text { Number of Wheel } \\
\text { Passes }\end{array}$} & \multirow[b]{2}{*}{ Specimen } & \multicolumn{6}{|c|}{ British Pendulum Number (BPN) } \\
\hline & & Trial 1 & Trial 2 & Trial 3 & Trial 4 & Trial 5 & Average \\
\hline 8000 & 2 & 61 & 59 & 57 & 56 & 56 & 57.8 \\
\hline 8000 & 3 & 60 & 59 & 58 & 56 & 55 & 57.6 \\
\hline 8000 & 5 & 56 & 56 & 55 & 54 & 53 & 54.8 \\
\hline 8000 & 6 & 61 & 60 & 58 & 57 & 56 & 58.4 \\
\hline 8000 & 8 & 54 & 53 & 50 & 49 & 50 & 51.2 \\
\hline 8000 & 9 & 56 & 55 & 54 & 54 & 53 & 54.4 \\
\hline 8000 & 11 & 54 & 52 & 52 & 51 & 51 & 52 \\
\hline 8000 & 12 & 61 & 59 & 56 & 55 & 54 & 57 \\
\hline 16000 & 2 & 52 & 50 & 49 & 48 & 48 & 49.4 \\
\hline 16000 & 3 & 60 & 58 & 58 & 57 & 56 & 57.8 \\
\hline 16000 & 5 & 55 & 53 & 52 & 51 & 51 & 52.4 \\
\hline 16000 & 6 & 53 & 52 & 50 & 49 & 50 & 50.8 \\
\hline 16000 & 8 & 58 & 55 & 54 & 54 & 53 & 54.8 \\
\hline 16000 & 9 & 54 & 52 & 51 & 51 & 50 & 51.6 \\
\hline 16000 & 11 & 50 & 50 & 49 & 48 & 48 & 49 \\
\hline 16000 & 12 & 52 & 50 & 49 & 49 & 48 & 49.6 \\
\hline 32000 & 2 & 72 & 62 & 60 & 59 & 58 & 62.2 \\
\hline 32000 & 3 & 60 & 59 & 55 & 55 & 54 & 56.6 \\
\hline 32000 & 5 & 55 & 54 & 54 & 50 & 49 & 52.4 \\
\hline 32000 & 6 & 56 & 54 & 52 & 54 & 51 & 53.4 \\
\hline 32000 & 8 & 50 & 49 & 49 & 46 & 46 & 48 \\
\hline 32000 & 9 & 53 & 53 & 49 & 48 & 47 & 50 \\
\hline 32000 & 11 & 54 & 53 & 51 & 53 & 52 & 52.6 \\
\hline 32000 & 12 & 56 & 54 & 52 & 51 & 51 & 52.8 \\
\hline 64000 & 2 & 50 & 47 & 46 & 45 & 45 & 46.6 \\
\hline 64000 & 3 & 46 & 44 & 42 & 41 & 40 & 42.6 \\
\hline 64000 & 5 & 52 & 50 & 48 & 48 & 46 & 48.8 \\
\hline 64000 & 6 & 46 & 44 & 43 & 42 & 42 & 43.4 \\
\hline 64000 & 8 & 44 & 42 & 41 & 40 & 39 & 41.2 \\
\hline
\end{tabular}




\begin{tabular}{|c|c|c|c|c|c|c|c|}
\hline \multirow[b]{2}{*}{$\begin{array}{c}\text { Number of Wheel } \\
\text { Passes }\end{array}$} & \multirow[b]{2}{*}{ Specimen } & \multicolumn{6}{|c|}{ British Pendulum Number (BPN) } \\
\hline & & Trial 1 & Trial 2 & Trial 3 & Trial 4 & Trial 5 & Average \\
\hline 64000 & 9 & 45 & 42 & 42 & 41 & 40 & 42 \\
\hline 64000 & 11 & 44 & 42 & 42 & 40 & 40 & 41.6 \\
\hline 64000 & 12 & 50 & 48 & 46 & 45 & 45 & 46.8 \\
\hline 96,508 & 2 & 45 & 43 & 41 & 40 & 39 & 41.6 \\
\hline 96,508 & 3 & 51 & 45 & 45 & 43 & 44 & 45.6 \\
\hline 96,508 & 5 & 47 & 45 & 42 & 42 & 41 & 43.4 \\
\hline 96,508 & 6 & 45 & 43 & 41 & 40 & 38 & 41.4 \\
\hline 96,508 & 8 & 42 & 39 & 38 & 36 & 36 & 38.2 \\
\hline 96,508 & 9 & 46 & 42 & 40 & 39 & 36 & 40.6 \\
\hline 96,508 & 11 & 46 & 43 & 42 & 41 & 40 & 42.4 \\
\hline 96,508 & 12 & 47 & 45 & 42 & 42 & 40 & 43.2 \\
\hline 128000 & 2 & 48 & 45 & 43 & 43 & 42 & 44.2 \\
\hline 128000 & 3 & 50 & 47 & 45 & 44 & 43 & 45.8 \\
\hline 128000 & 5 & 46 & 46 & 43 & 43 & 42 & 44 \\
\hline 128000 & 6 & 45 & 42 & 42 & 40 & 40 & 41.8 \\
\hline 128000 & 8 & 41 & 39 & 39 & 36 & 35 & 38 \\
\hline 128000 & 9 & 48 & 45 & 45 & 43 & 42 & 44.6 \\
\hline 128000 & 11 & 47 & 44 & 43 & 42 & 41 & 43.4 \\
\hline 128000 & 12 & 46 & 43 & 42 & 41 & 41 & 42.6 \\
\hline 160000 & 2 & 48 & 46 & 43 & 42 & 41 & 44 \\
\hline 160000 & 3 & 50 & 47 & 44 & 43 & 42 & 45.2 \\
\hline 160000 & 5 & 47 & 44 & 41 & 41 & 40 & 42.6 \\
\hline 160000 & 6 & 47 & 44 & 42 & 40 & 39 & 42.4 \\
\hline 160000 & 8 & 46 & 45 & 43 & 41 & 40 & 43 \\
\hline 160000 & 9 & 45 & 43 & 40 & 38 & 37 & 40.6 \\
\hline 160000 & 11 & 46 & 44 & 41 & 41 & 38 & 42 \\
\hline 160000 & 12 & 50 & 48 & 44 & 43 & 42 & 45.4 \\
\hline 160000 & 1 & 45 & 42 & 40 & 29 & 37 & 38.6 \\
\hline 160000 & 4 & 38 & 45 & 35 & 34 & 32 & 36.8 \\
\hline 160000 & 7 & 40 & 38 & 36 & 36 & 35 & 37 \\
\hline 160000 & 10 & 42 & 39 & 37 & 36 & 35 & 37.8 \\
\hline
\end{tabular}




\section{Trial 2: JFA 12.5mm SR and WVP W1-RAP Specimens (Top}

\section{Surfaces)}

Table 46: BPN Measurements for Trial 2 JFA 12.5mm SR and WVP W1-RAP (Top Surface) Specimens Polished with Burris B55A Tires at Low Toe for 48,000 Wheel Passes

\begin{tabular}{|c|c|c|c|c|c|c|c|c|}
\hline \multirow[b]{2}{*}{ Mix Type } & \multirow{2}{*}{$\begin{array}{c}\text { Number of } \\
\text { Wheel } \\
\text { Passes }\end{array}$} & \multirow[b]{2}{*}{ Specimen } & \multicolumn{6}{|c|}{ British Pendulum Number (BPN) } \\
\hline & & & $\begin{array}{c}\text { Trial } \\
1\end{array}$ & $\begin{array}{c}\text { Trial } \\
2\end{array}$ & $\begin{array}{c}\text { Trial } \\
3\end{array}$ & $\begin{array}{c}\text { Trial } \\
4\end{array}$ & Average & $\begin{array}{c}\text { Mix } \\
\text { Average }\end{array}$ \\
\hline \multirow{3}{*}{$\begin{array}{c}\text { JFA } 12.5 \mathrm{~mm} \\
\text { Skid-RAP } \\
\text { 8\% VTM } \\
\end{array}$} & 0 & $1 \mathrm{~T}$ & 81 & 81 & 77 & 77 & 79.0 & \\
\hline & 0 & $2 \mathrm{~T}$ & 77 & 75 & 77 & 77 & 76.5 & \\
\hline & 0 & $3 \mathrm{~T}$ & 81 & 80 & 77 & 76 & 78.5 & 78.0 \\
\hline \multirow{3}{*}{$\begin{array}{c}\text { JFA 12.5mm } \\
\text { Skid-RAP } \\
\text { 4\% VTM } \\
\end{array}$} & 0 & $4 \mathrm{~T}$ & 84 & 82 & 82 & 81 & 82.3 & \\
\hline & 0 & $5 \mathrm{~T}$ & 85 & 85 & 84 & 81 & 83.8 & \\
\hline & 0 & $6 \mathrm{~T}$ & 77 & 76 & 76 & 75 & 76.0 & 80.7 \\
\hline \multirow{3}{*}{$\begin{array}{l}\text { WV Paving } \\
\text { W1-RAP } \\
\text { 4\% VTM }\end{array}$} & 0 & $7 \mathrm{~T}$ & 86 & 78 & 84 & 82 & 82.5 & \\
\hline & 0 & $8 \mathrm{~T}$ & 85 & 82 & 79 & 77 & 80.8 & \\
\hline & 0 & $9 \mathrm{~T}$ & 85 & 85 & 84 & 83 & 84.3 & 82.5 \\
\hline \multirow{3}{*}{$\begin{array}{c}\text { WV Paving } \\
\text { W1-RAP } \\
\text { 8\% VTM }\end{array}$} & 0 & $10 \mathrm{~T}$ & 88 & 81 & 80 & 83 & 83.0 & \\
\hline & 0 & $11 \mathrm{~T}$ & 88 & 87 & 85 & 83 & 85.8 & \\
\hline & 0 & $12 \mathrm{~T}$ & 84 & 83 & 82 & 81 & 82.5 & 83.8 \\
\hline \multirow{3}{*}{$\begin{array}{c}\text { JFA 12.5mm } \\
\text { Skid-RAP } \\
\text { 8\% VTM } \\
\end{array}$} & 8000 & $1 \mathrm{~T}$ & 65 & 62 & 59 & 61 & 61.8 & \\
\hline & 8000 & $2 \mathrm{~T}$ & 60 & 58 & 58 & 57 & 58.3 & \\
\hline & 8000 & $3 \mathrm{~T}$ & 63 & 60 & 55 & 54 & 58.0 & 59.3 \\
\hline \multirow{3}{*}{$\begin{array}{c}\text { JFA } 12.5 \mathrm{~mm} \\
\text { Skid-RAP } \\
\text { 4\% VTM }\end{array}$} & 8000 & $4 \mathrm{~T}$ & 58 & 49 & 50 & 55 & 53.0 & \\
\hline & 8000 & $5 \mathrm{~T}$ & 59 & 56 & 56 & 56 & 56.8 & \\
\hline & 8000 & $6 \mathrm{~T}$ & 57 & 58 & 57 & 54 & 56.5 & 55.4 \\
\hline \multirow{3}{*}{$\begin{array}{c}\text { WV Paving } \\
\text { W1-RAP } \\
\text { 4\% VTM }\end{array}$} & 8000 & $7 \mathrm{~T}$ & 64 & 61 & 59 & 56 & 60.0 & \\
\hline & 8000 & $8 \mathrm{~T}$ & 64 & 60 & 60 & 59 & 60.8 & \\
\hline & 8000 & $9 \mathrm{~T}$ & 64 & 62 & 58 & 61 & 61.3 & 60.7 \\
\hline \multirow{3}{*}{$\begin{array}{c}\text { WV Paving } \\
\text { W1-RAP } \\
\text { 8\% VTM }\end{array}$} & 8000 & $10 \mathrm{~T}$ & 65 & 62 & 61 & 58 & 61.5 & \\
\hline & 8000 & $11 \mathrm{~T}$ & 63 & 62 & 62 & 60 & 61.8 & \\
\hline & 8000 & $12 \mathrm{~T}$ & 63 & 63 & 61 & 60 & 61.8 & 61.7 \\
\hline \multirow{3}{*}{$\begin{array}{c}\text { JFA 12.5mm } \\
\text { Skid-RAP } \\
\text { 8\% VTM } \\
\end{array}$} & 16000 & $1 \mathrm{~T}$ & 56 & 56 & 55 & 55 & 56 & \\
\hline & 16000 & $2 \mathrm{~T}$ & 53 & 52 & 51 & 50 & 52 & \\
\hline & 16000 & $3 \mathrm{~T}$ & 56 & 56 & 50 & 54 & 54 & 53.7 \\
\hline \multirow{4}{*}{$\begin{array}{c}\text { JFA 12.5mm } \\
\text { Skid-RAP } \\
\text { 4\% VTM }\end{array}$} & 16000 & $4 \mathrm{~T}$ & 43 & 45 & 49 & 49 & 47 & \\
\hline & 16000 & $5 \mathrm{~T}$ & 55 & 51 & 49 & 52 & 52 & \\
\hline & 16000 & $6 \mathrm{~T}$ & 51 & 49 & 49 & 52 & 50 & 51.1 \\
\hline & 16000 & $7 \mathrm{~T}$ & 59 & 54 & 55 & 55 & 56 & \\
\hline
\end{tabular}




\begin{tabular}{|c|c|c|c|c|c|c|c|c|}
\hline \multirow[b]{2}{*}{ Mix Type } & \multirow{2}{*}{$\begin{array}{c}\text { Number of } \\
\text { Wheel } \\
\text { Passes }\end{array}$} & \multirow[b]{2}{*}{ Specimen } & \multicolumn{6}{|c|}{ British Pendulum Number (BPN) } \\
\hline & & & $\begin{array}{c}\text { Trial } \\
1\end{array}$ & $\begin{array}{c}\text { Trial } \\
2\end{array}$ & $\begin{array}{c}\text { Trial } \\
\mathbf{3}\end{array}$ & $\begin{array}{c}\text { Trial } \\
4\end{array}$ & Average & $\begin{array}{c}\text { Mix } \\
\text { Average }\end{array}$ \\
\hline \multirow{2}{*}{$\begin{array}{c}\text { WV Paving } \\
\text { W1-RAP } \\
\text { 4\% VTM }\end{array}$} & 16000 & $8 \mathrm{~T}$ & 56 & 55 & 55 & 54 & 55 & \\
\hline & 16000 & $9 \mathrm{~T}$ & 59 & 54 & 54 & 52 & 55 & 55.2 \\
\hline \multirow{3}{*}{$\begin{array}{c}\text { WV Paving } \\
\text { W1-RAP } \\
\text { 8\% VTM } \\
\end{array}$} & 16000 & $10 \mathrm{~T}$ & 58 & 55 & 56 & 55 & 56 & \\
\hline & 16000 & $11 \mathrm{~T}$ & 60 & 56 & 58 & 57 & 58 & \\
\hline & 16000 & $12 \mathrm{~T}$ & 59 & 51 & 52 & 55 & 54 & 56.0 \\
\hline \multirow{3}{*}{$\begin{array}{c}\text { JFA 12.5mm } \\
\text { Skid-RAP } \\
\text { 8\% VTM } \\
\end{array}$} & 32000 & $1 \mathrm{~T}$ & 55 & 54 & 53 & 53 & 53.8 & \\
\hline & 32000 & $2 \mathrm{~T}$ & 50 & 49 & 49 & 48 & 49.0 & \\
\hline & 32000 & $3 \mathrm{~T}$ & 52 & 50 & 49 & 48 & 49.8 & $\begin{array}{l}50.8 \\
\end{array}$ \\
\hline \multirow{3}{*}{$\begin{array}{c}\text { JFA } 12.5 \mathrm{~mm} \\
\text { Skid-RAP } \\
\text { 4\% VTM }\end{array}$} & 32000 & $4 \mathrm{~T}$ & 52 & 51 & 50 & 49 & 50.5 & \\
\hline & 32000 & $5 \mathrm{~T}$ & 51 & 50 & 49 & 48 & 49.5 & \\
\hline & 32000 & $6 \mathrm{~T}$ & 51 & 49 & 48 & 48 & 49.0 & 49.7 \\
\hline \multirow{3}{*}{$\begin{array}{c}\text { WV Paving } \\
\text { W1-RAP } \\
\text { 4\% VTM }\end{array}$} & 32000 & $7 \mathrm{~T}$ & 55 & 53 & 52 & 51 & 52.8 & \\
\hline & 32000 & $8 \mathrm{~T}$ & 55 & 53 & 52 & 52 & 53.0 & \\
\hline & 32000 & $9 \mathrm{~T}$ & 54 & 52 & 52 & 52 & 52.5 & 52.8 \\
\hline \multirow{3}{*}{$\begin{array}{c}\text { WV Paving } \\
\text { W1-RAP } \\
\text { 8\% VTM } \\
\end{array}$} & 32000 & $10 \mathrm{~T}$ & 56 & 54 & 54 & 53 & 54.3 & \\
\hline & 32000 & $11 \mathrm{~T}$ & 55 & 51 & 52 & 52 & \begin{tabular}{|l|}
52.5 \\
\end{tabular} & \\
\hline & 32000 & $12 \mathrm{~T}$ & 55 & 56 & 54 & 54 & 54.8 & 53.8 \\
\hline \multirow{3}{*}{\begin{tabular}{c|} 
JFA 12.5mm \\
Skid-RAP \\
8\% VTM \\
\end{tabular}} & 48000 & $1 \mathrm{~T}$ & 54 & 52 & 50 & 50 & 51.5 & \\
\hline & 48000 & $2 \mathrm{~T}$ & 50 & 48 & 47 & 46 & 47.8 & \\
\hline & 48000 & $3 \mathrm{~T}$ & 52 & 50 & 48 & 47 & 49.3 & 49.5 \\
\hline \multirow{3}{*}{$\begin{array}{c}\text { JFA 12.5mm } \\
\text { Skid-RAP } \\
4 \% \text { VTM }\end{array}$} & 48000 & $4 \mathrm{~T}$ & 51 & 48 & 47 & 46 & 48.0 & \\
\hline & 48000 & $5 \mathrm{~T}$ & 48 & 46 & 45 & 44 & 45.8 & \\
\hline & 48000 & $6 \mathrm{~T}$ & 50 & 48 & 46 & 46 & 47.5 & 47.1 \\
\hline \multirow{3}{*}{$\begin{array}{c}\text { WV Paving } \\
\text { W1-RAP } \\
\text { 4\% VTM }\end{array}$} & 48000 & $7 \mathrm{~T}$ & 54 & 52 & 50 & 49 & 51.3 & \\
\hline & 48000 & $8 \mathrm{~T}$ & 54 & 52 & 51 & 50 & 51.8 & \\
\hline & 48000 & $9 \mathrm{~T}$ & 52 & 49 & 48 & 48 & 49.3 & 50.8 \\
\hline \multirow{3}{*}{$\begin{array}{c}\text { WV Paving } \\
\text { W1-RAP } \\
\text { 8\% VTM }\end{array}$} & 48000 & $10 \mathrm{~T}$ & 54 & 52 & 51 & 50 & 51.8 & \\
\hline & 48000 & $11 \mathrm{~T}$ & 53 & 51 & 49 & 48 & \begin{tabular}{|l|}
50.3 \\
\end{tabular} & \\
\hline & 48000 & $12 \mathrm{~T}$ & 58 & 56 & 55 & 54 & 55.8 & 52.6 \\
\hline
\end{tabular}




\section{Trial 3: JFA 12.5mm SR and WVP W1-RAP Specimens}

\section{(Bottom Surfaces)}

Table 47: BPN Measurements for Trial 3 JFA 12.5mm SR and WVP W1-RAP (Bottom Surface) Specimens Polished with Burris B55A Tires at High Toe for 80,000 Wheel Passes

\begin{tabular}{|c|c|c|c|c|c|c|c|c|}
\hline \multirow[b]{2}{*}{ Mix Type } & \multirow{2}{*}{$\begin{array}{c}\text { Number of } \\
\text { Wheel } \\
\text { Passes }\end{array}$} & \multirow[b]{2}{*}{ Sample } & \multicolumn{6}{|c|}{ British Pendulum Number (BPN) } \\
\hline & & & $\begin{array}{c}\text { Trial } \\
1\end{array}$ & $\begin{array}{c}\text { Trial } \\
2\end{array}$ & $\begin{array}{c}\text { Trial } \\
\mathbf{3}\end{array}$ & $\begin{array}{c}\text { Trial } \\
4\end{array}$ & Average & $\begin{array}{c}\text { Mix } \\
\text { Average }\end{array}$ \\
\hline \multirow{3}{*}{$\begin{array}{c}\text { JFA } 12.5 \mathrm{~mm} \\
\text { Skid-RAP } 8 \% \\
\text { VTM }\end{array}$} & 0 & $1 \mathrm{~B}$ & 72 & 72 & 69 & 70 & 70.8 & \\
\hline & 0 & $2 \mathrm{~B}$ & 72 & 72 & 71 & 70 & 71.3 & \\
\hline & 0 & $3 \mathrm{~B}$ & 72 & 70 & 69 & 67 & 69.5 & 70.5 \\
\hline \multirow{3}{*}{$\begin{array}{c}\text { JFA } 12.5 \mathrm{~mm} \\
\text { Skid-RAP } 4 \% \\
\text { VTM }\end{array}$} & 0 & $4 \mathrm{~B}$ & 73 & 71 & 70 & 69 & 70.8 & \\
\hline & 0 & $5 B$ & 75 & 75 & 74 & 73 & 74.3 & \\
\hline & 0 & $6 \mathrm{~B}$ & 69 & 67 & 67 & 67 & 67.5 & 70.8 \\
\hline \multirow{3}{*}{$\begin{array}{l}\text { WV Paving W1- } \\
\text { RAP 4\% VTM }\end{array}$} & 0 & $7 \mathrm{~B}$ & 80 & 79 & 78 & 77 & 78.5 & \\
\hline & 0 & $8 \mathrm{~B}$ & 79 & 77 & 77 & 75 & 77.0 & \\
\hline & 0 & $9 B$ & 80 & 79 & 77 & 73 & 77.3 & 77.6 \\
\hline \multirow{3}{*}{$\begin{array}{l}\text { WV Paving W1- } \\
\text { RAP } 8 \% \text { VTM }\end{array}$} & 0 & $10 \mathrm{~B}$ & 83 & 81 & 80 & 77 & 80.3 & \\
\hline & 0 & $11 \mathrm{~B}$ & 75 & 74 & 73 & 73 & 73.8 & \\
\hline & 0 & $12 \mathrm{~B}$ & 74 & 73 & 70 & 72 & 72.3 & 75.4 \\
\hline \multirow{4}{*}{$\begin{array}{c}\text { JFA } 12.5 \mathrm{~mm} \\
\text { Skid-RAP } 8 \% \\
\text { VTM }\end{array}$} & & & & & & & & \\
\hline & 8000 & $1 \mathrm{~B}$ & 54 & 52 & 51 & 50 & 51.8 & \\
\hline & 8000 & $2 \mathrm{~B}$ & 55 & 54 & 53 & 52 & 53.5 & \\
\hline & 8000 & $3 B$ & 55 & 54 & 53 & 53 & 53.8 & 53.0 \\
\hline \multirow{3}{*}{$\begin{array}{c}\text { JFA } 12.5 \mathrm{~mm} \\
\text { Skid-RAP } 4 \% \\
\text { VTM }\end{array}$} & 8000 & $4 B$ & 54 & 52 & 51 & 51 & 52.0 & \\
\hline & 8000 & $5 B$ & 56 & 54 & 54 & 53 & 54.3 & \\
\hline & 8000 & $6 \mathrm{~B}$ & 54 & 53 & 52 & 52 & 52.8 & 53.0 \\
\hline \multirow{3}{*}{$\begin{array}{l}\text { WV Paving W1- } \\
\text { RAP 4\% VTM }\end{array}$} & 8000 & $7 \mathrm{~B}$ & 60 & 58 & 58 & 57 & 58.3 & \\
\hline & 8000 & $8 \mathrm{~B}$ & 57 & 56 & 55 & 55 & 55.8 & \\
\hline & 8000 & $9 \mathrm{~B}$ & 61 & 59 & 58 & 58 & 59.0 & 57.7 \\
\hline \multirow{3}{*}{$\begin{array}{l}\text { WV Paving W1- } \\
\text { RAP } 8 \% \text { VTM }\end{array}$} & 8000 & $10 \mathrm{~B}$ & 58 & 56 & 56 & 55 & 56.3 & \\
\hline & 8000 & $11 \mathrm{~B}$ & 60 & 59 & 58 & 57 & 58.5 & \\
\hline & 8000 & $12 \mathrm{~B}$ & 59 & 57 & 56 & 56 & 57.0 & 57.3 \\
\hline \multirow{3}{*}{$\begin{array}{c}\text { JFA } 12.5 \mathrm{~mm} \\
\text { Skid-RAP } 8 \% \\
\text { VTM }\end{array}$} & 16000 & $1 \mathrm{~B}$ & 51 & 49 & 48 & 48 & 49.0 & \\
\hline & 16000 & $2 \mathrm{~B}$ & 51 & 50 & 48 & 48 & 49.3 & \\
\hline & 16000 & $3 \mathrm{~B}$ & 51 & 49 & 48 & 47 & 48.8 & 49.0 \\
\hline \multirow{4}{*}{$\begin{array}{c}\text { JFA } 12.5 \mathrm{~mm} \\
\text { Skid-RAP } 4 \% \\
\text { VTM }\end{array}$} & 16000 & 4B & 50 & 48 & 48 & 47 & 48.3 & \\
\hline & 16000 & $5 B$ & 53 & 52 & 51 & 50 & 51.5 & \\
\hline & 16000 & $6 \mathrm{~B}$ & 50 & 48 & 48 & 47 & 48.3 & 50.6 \\
\hline & 16000 & $7 B$ & 56 & 55 & 54 & 53 & 54.5 & \\
\hline
\end{tabular}




\begin{tabular}{|c|c|c|c|c|c|c|c|c|}
\hline \multirow[b]{2}{*}{ Mix Type } & \multirow{2}{*}{$\begin{array}{c}\text { Number of } \\
\text { Wheel } \\
\text { Passes }\end{array}$} & \multirow[b]{2}{*}{ Sample } & \multicolumn{6}{|c|}{ British Pendulum Number (BPN) } \\
\hline & & & $\begin{array}{c}\text { Trial } \\
1\end{array}$ & $\begin{array}{c}\text { Trial } \\
2\end{array}$ & $\begin{array}{c}\text { Trial } \\
\mathbf{3}\end{array}$ & $\begin{array}{c}\text { Trial } \\
4\end{array}$ & Average & $\begin{array}{c}\text { Mix } \\
\text { Average }\end{array}$ \\
\hline \multirow{2}{*}{$\begin{array}{l}\text { WV Paving W1- } \\
\text { RAP } 4 \% \text { VTM }\end{array}$} & 16000 & $8 \mathrm{~B}$ & 54 & 52 & 52 & 51 & 52.3 & \\
\hline & 16000 & $9 \mathrm{~B}$ & 56 & 55 & 54 & 53 & 54.5 & 53.8 \\
\hline \multirow{3}{*}{$\begin{array}{l}\text { WV Paving W1- } \\
\text { RAP 8\% VTM }\end{array}$} & 16000 & $10 \mathrm{~B}$ & 55 & 53 & 52 & 51 & 52.8 & \\
\hline & 16000 & $11 \mathrm{~B}$ & 54 & 53 & 52 & 52 & 52.8 & \\
\hline & 16000 & $12 \mathrm{~B}$ & 54 & 53 & 53 & 52 & 53.0 & 52.8 \\
\hline \multirow{4}{*}{$\begin{array}{c}\text { JFA } 12.5 \mathrm{~mm} \\
\text { Skid-RAP } 8 \% \\
\text { VTM }\end{array}$} & & & & & & & & \\
\hline & 32000 & 1B & 49 & 48 & 47 & 46 & 47.5 & \\
\hline & 32000 & $2 \mathrm{~B}$ & 54 & 52 & 51 & 50 & 51.8 & \\
\hline & 32000 & $3 B$ & 52 & 51 & 49 & 49 & 50.3 & 49.8 \\
\hline \multirow{3}{*}{$\begin{array}{c}\text { JFA } 12.5 \mathrm{~mm} \\
\text { Skid-RAP } 4 \% \\
\text { VTM }\end{array}$} & 32000 & $4 \mathrm{~B}$ & 50 & 48 & 47 & 47 & 48.0 & \\
\hline & 32000 & $5 B$ & 51 & 50 & 48 & 48 & 49.3 & \\
\hline & 32000 & $6 B$ & 50 & 48 & 47 & 46 & 47.8 & 48.3 \\
\hline \multirow{3}{*}{$\begin{array}{l}\text { WV Paving W1- } \\
\text { RAP 4\% VTM }\end{array}$} & 32000 & $7 \mathrm{~B}$ & 53 & 52 & 50 & 49 & 51.0 & \\
\hline & 32000 & $8 \mathrm{~B}$ & 53 & 51 & 50 & 49 & 50.8 & \\
\hline & 32000 & $9 B$ & 54 & 52 & 52 & 51 & 52.3 & 51.3 \\
\hline \multirow{3}{*}{$\begin{array}{l}\text { WV Paving W1- } \\
\text { RAP 8\% VTM }\end{array}$} & 32000 & $10 \mathrm{~B}$ & 53 & 51 & 50 & 49 & 50.8 & \\
\hline & 32000 & $11 \mathrm{~B}$ & 53 & 52 & 51 & 50 & 51.5 & \\
\hline & 32000 & $12 \mathrm{~B}$ & 53 & 52 & 51 & 50 & 51.5 & 51.3 \\
\hline \multirow{4}{*}{$\begin{array}{c}\text { JFA } 12.5 \mathrm{~mm} \\
\text { Skid-RAP } 8 \% \\
\text { VTM }\end{array}$} & & & & & & & & \\
\hline & 48000 & $1 \mathrm{~B}$ & 51 & 49 & 48 & 46 & 48.5 & \\
\hline & 48000 & $2 B$ & 51 & 48 & 47 & 46 & 48.0 & \\
\hline & 48000 & $3 B$ & 52 & 49 & 48 & 47 & 49.0 & 48.5 \\
\hline \multirow{3}{*}{$\begin{array}{c}\text { JFA } 12.5 \mathrm{~mm} \\
\text { Skid-RAP } 4 \% \\
\text { VTM }\end{array}$} & 48000 & $4 B$ & 47 & 45 & 44 & 43 & 44.8 & \\
\hline & 48000 & $5 B$ & 50 & 48 & 47 & 46 & 47.8 & \\
\hline & 48000 & $6 B$ & 50 & 48 & 47 & 46 & 47.8 & 46.8 \\
\hline \multirow{3}{*}{$\begin{array}{l}\text { WV Paving W1- } \\
\text { RAP 4\% VTM }\end{array}$} & 48000 & $7 \mathrm{~B}$ & 52 & 50 & 48 & 47 & 49.3 & \\
\hline & 48000 & $8 B$ & 51 & 49 & 48 & 47 & 48.8 & \\
\hline & 48000 & $9 B$ & 51 & 49 & 48 & 48 & 49.0 & 49.0 \\
\hline \multirow{3}{*}{$\begin{array}{l}\text { WV Paving W1- } \\
\text { RAP 8\% VTM }\end{array}$} & 48000 & $10 \mathrm{~B}$ & 52 & 49 & 48 & 48 & 49.3 & \\
\hline & 48000 & $11 \mathrm{~B}$ & 53 & 50 & 49 & 48 & 50.0 & \\
\hline & 48000 & $12 \mathrm{~B}$ & 52 & 50 & 49 & 48 & 49.8 & 49.7 \\
\hline \multirow{4}{*}{$\begin{array}{c}\text { JFA } 12.5 \mathrm{~mm} \\
\text { Skid-RAP } 8 \% \\
\text { VTM }\end{array}$} & & & & & & & & \\
\hline & 64000 & $1 \mathrm{~B}$ & 52 & 49 & 47 & 46 & 48.5 & \\
\hline & 64000 & $2 B$ & 53 & 49 & 48 & 47 & 49.3 & \\
\hline & 64000 & $3 \mathrm{~B}$ & 50 & 48 & 47 & 46 & 47.8 & 48.5 \\
\hline \multirow{3}{*}{$\begin{array}{c}\text { JFA } 12.5 \mathrm{~mm} \\
\text { Skid-RAP } 4 \% \\
\text { VTM }\end{array}$} & 64000 & $4 \mathrm{~B}$ & 54 & 51 & 49 & 47 & 50.3 & \\
\hline & 64000 & $5 B$ & 49 & 48 & 47 & 46 & 47.5 & \\
\hline & 64000 & $6 \mathrm{~B}$ & 47 & 46 & 45 & 45 & 45.8 & 47.8 \\
\hline \multirow{2}{*}{$\begin{array}{l}\text { WV Paving W1- } \\
\text { RAP 4\% VTM }\end{array}$} & 64000 & $7 B$ & 55 & 52 & 49 & 47 & 50.8 & \\
\hline & 64000 & $8 \mathrm{~B}$ & 53 & 50 & 48 & 47 & 49.5 & \\
\hline
\end{tabular}




\begin{tabular}{|c|c|c|c|c|c|c|c|c|}
\hline \multirow{3}{*}{ Mix Type } & \multirow{2}{*}{$\begin{array}{c}\text { Number of } \\
\text { Wheel } \\
\text { Passes } \\
\end{array}$} & \multirow[b]{2}{*}{ Sample } & \multicolumn{6}{|c|}{ British Pendulum Number (BPN) } \\
\hline & & & $\begin{array}{c}\text { Trial } \\
1\end{array}$ & $\begin{array}{c}\text { Trial } \\
2\end{array}$ & $\begin{array}{c}\text { Trial } \\
\mathbf{3}\end{array}$ & $\begin{array}{c}\text { Trial } \\
4\end{array}$ & Average & $\begin{array}{c}\text { Mix } \\
\text { Average }\end{array}$ \\
\hline & 64000 & $9 \mathrm{~B}$ & 55 & 52 & 51 & 49 & 51.8 & 50.7 \\
\hline \multirow{3}{*}{$\begin{array}{l}\text { WV Paving W1- } \\
\text { RAP 8\% VTM }\end{array}$} & 64000 & $10 \mathrm{~B}$ & 53 & 50 & 48 & 47 & 49.5 & \\
\hline & 64000 & $11 \mathrm{~B}$ & 53 & 50 & 48 & 47 & 49.5 & \\
\hline & 64000 & $12 \mathrm{~B}$ & 53 & 51 & 49 & 47 & $\mathbf{5 0 . 0}$ & 49.7 \\
\hline & & & & & & & & \\
\hline \multirow{3}{*}{$\begin{array}{c}\text { JFA } 12.5 \mathrm{~mm} \\
\text { Skid-RAP } 8 \% \\
\text { VTM }\end{array}$} & 80000 & $1 \mathrm{~B}$ & 55 & 52 & 49 & 47 & 50.8 & \\
\hline & 80000 & $2 \mathrm{~B}$ & 57 & 53 & 51 & 49 & 52.5 & \\
\hline & 80000 & $3 \mathrm{~B}$ & 57 & 53 & 50 & 49 & 52.3 & 51.8 \\
\hline \multirow{3}{*}{$\begin{array}{c}\text { JFA } 12.5 \mathrm{~mm} \\
\text { Skid-RAP } 4 \% \\
\text { VTM }\end{array}$} & 80000 & $4 B$ & 55 & 52 & 49 & 48 & 51.0 & \\
\hline & 80000 & $5 B$ & 56 & 53 & 50 & 48 & 51.8 & \\
\hline & 80000 & $6 B$ & 57 & 54 & 51 & 49 & 52.8 & 51.8 \\
\hline \multirow{3}{*}{$\begin{array}{l}\text { WV Paving W1- } \\
\text { RAP 4\% VTM }\end{array}$} & 80000 & $7 \mathrm{~B}$ & 54 & 50 & 48 & 47 & 49.8 & \\
\hline & 80000 & $8 \mathrm{~B}$ & 55 & 52 & 49 & 48 & 51.0 & \\
\hline & 80000 & $9 B$ & 54 & 51 & 48 & 47 & 50.0 & 50.3 \\
\hline \multirow{3}{*}{$\begin{array}{l}\text { WV Paving W1- } \\
\text { RAP } 8 \% \text { VTM }\end{array}$} & 80000 & $10 \mathrm{~B}$ & 56 & 52 & 50 & 48 & 51.5 & \\
\hline & 80000 & $11 \mathrm{~B}$ & 53 & 50 & 48 & 47 & 49.5 & \\
\hline & 80000 & $12 \mathrm{~B}$ & 55 & 52 & 50 & 48 & 51.3 & 50.8 \\
\hline
\end{tabular}

\section{Trial 4: WVP 12.5mm SR and Greer W1H Specimens (Top}

\section{Surfaces)}

Table 48: BPN Measurements for Trial 4 WVP 12.5mm SR and Greer W1H (Top Surface) Specimens Polished with Hoosier R80 Tires at High Toe for 48,000 Wheel Passes

\begin{tabular}{|c|c|c|c|c|c|c|c|c|}
\hline \multirow[b]{2}{*}{ Mix Type } & \multirow{2}{*}{$\begin{array}{c}\text { Number of } \\
\text { Wheel } \\
\text { Passes }\end{array}$} & \multirow[b]{2}{*}{ Specimen } & \multicolumn{6}{|c|}{ British Pendulum Number (BPN) } \\
\hline & & & $\begin{array}{c}\text { Trial } \\
1\end{array}$ & $\begin{array}{c}\text { Trial } \\
2\end{array}$ & $\begin{array}{c}\text { Trial } \\
\mathbf{3}\end{array}$ & $\begin{array}{c}\text { Trial } \\
4\end{array}$ & Average & $\begin{array}{c}\text { Mix } \\
\text { Average }\end{array}$ \\
\hline \multirow{3}{*}{$\begin{array}{c}\text { Greer W1 Heavy 8\% } \\
\text { VTM }\end{array}$} & 0 & $13 \mathrm{~T}$ & 83 & 82 & 81 & 80 & 81.5 & \\
\hline & 0 & $14 \mathrm{~T}$ & 84 & 84 & 83 & 82 & 83.3 & \\
\hline & 0 & $15 \mathrm{~T}$ & 82 & 81 & 80 & 80 & 80.8 & 81.8 \\
\hline \multirow{3}{*}{$\begin{array}{c}\text { Greer W1 Heavy } 4 \% \\
\text { VTM }\end{array}$} & 0 & $16 \mathrm{~T}$ & 85 & 84 & 84 & 83 & 84.0 & \\
\hline & 0 & $17 \mathrm{~T}$ & 88 & 88 & 87 & 86 & 87.3 & \\
\hline & 0 & $18 \mathrm{~T}$ & 85 & 85 & 83 & 82 & 83.8 & 85.0 \\
\hline \multirow{4}{*}{$\begin{array}{l}\text { WV Paving } 12.5 \mathrm{~mm} \\
\text { Skid-RAP 4\% VTM }\end{array}$} & 0 & $19 \mathrm{~T}$ & 85 & 83 & 83 & 81 & 83.0 & \\
\hline & 0 & $20 \mathrm{~T}$ & 87 & 85 & 84 & 82 & 84.5 & \\
\hline & 0 & $21 \mathrm{~T}$ & 85 & 85 & 83 & 83 & 84.0 & 83.8 \\
\hline & 0 & $22 \mathrm{~T}$ & 86 & 86 & 85 & 84 & 85.3 & \\
\hline
\end{tabular}




\begin{tabular}{|c|c|c|c|c|c|c|c|c|}
\hline \multirow{4}{*}{$\begin{array}{c}\text { Mix Type } \\
\text { WV Paving 12.5mm } \\
\text { Skid-RAP 8\% VTM }\end{array}$} & \multirow{2}{*}{$\begin{array}{c}\text { Number of } \\
\text { Wheel } \\
\text { Passes }\end{array}$} & \multirow[b]{2}{*}{ Specimen } & \multicolumn{6}{|c|}{ British Pendulum Number (BPN) } \\
\hline & & & $\begin{array}{c}\text { Trial } \\
1\end{array}$ & $\begin{array}{c}\text { Trial } \\
2\end{array}$ & $\begin{array}{c}\text { Trial } \\
\mathbf{3}\end{array}$ & $\begin{array}{c}\text { Trial } \\
4\end{array}$ & Average & $\begin{array}{c}\text { Mix } \\
\text { Average }\end{array}$ \\
\hline & 0 & $23 \mathrm{~T}$ & 88 & 89 & 88 & 87 & 88.0 & \\
\hline & 0 & $24 \mathrm{~T}$ & 86 & 85 & 84 & 82 & 84.3 & 85.8 \\
\hline \multirow{4}{*}{$\begin{array}{c}\text { Greer W1 Heavy } 8 \% \\
\text { VTM }\end{array}$} & & & & & & & & \\
\hline & 8000 & $13 \mathrm{~T}$ & 55 & 54 & 53 & 53 & 53.8 & \\
\hline & 8000 & $14 \mathrm{~T}$ & 55 & 54 & 54 & 54 & 54.3 & \\
\hline & 8000 & $15 \mathrm{~T}$ & 53 & 53 & 52 & 52 & 52.5 & 53.5 \\
\hline \multirow{3}{*}{$\begin{array}{c}\text { Greer W1 Heavy 4\% } \\
\text { VTM }\end{array}$} & 8000 & $16 \mathrm{~T}$ & 52 & 51 & 50 & 50 & 50.8 & \\
\hline & 8000 & $17 \mathrm{~T}$ & 55 & 53 & 53 & 52 & 53.3 & \\
\hline & 8000 & $18 \mathrm{~T}$ & 56 & 55 & 54 & 53 & 54.5 & 52.8 \\
\hline \multirow{3}{*}{$\begin{array}{l}\text { WV Paving } 12.5 \mathrm{~mm} \\
\text { Skid-RAP 4\% VTM }\end{array}$} & 8000 & $19 \mathrm{~T}$ & 57 & 56 & 55 & 54 & 55.5 & \\
\hline & 8000 & $20 \mathrm{~T}$ & 58 & 56 & 55 & 55 & $\begin{array}{l}56.0 \\
\end{array}$ & \\
\hline & 8000 & $21 \mathrm{~T}$ & 57 & 56 & 55 & 54 & 55.5 & 55.7 \\
\hline \multirow{3}{*}{$\begin{array}{l}\text { WV Paving } 12.5 \mathrm{~mm} \\
\text { Skid-RAP 8\% VTM }\end{array}$} & 8000 & $22 \mathrm{~T}$ & 60 & 59 & 58 & 57 & 58.5 & \\
\hline & 8000 & $23 \mathrm{~T}$ & 60 & 58 & 57 & 56 & 57.8 & \\
\hline & 8000 & $24 \mathrm{~T}$ & 59 & 57 & 57 & 56 & 57.3 & 57.8 \\
\hline & & & & & & & & \\
\hline \multirow{3}{*}{$\begin{array}{c}\text { Greer W1 Heavy } 8 \% \\
\text { VTM }\end{array}$} & 16000 & $13 \mathrm{~T}$ & 50 & 49 & 48 & 47 & 48.5 & \\
\hline & 16000 & $14 \mathrm{~T}$ & 50 & 49 & 49 & 48 & 49.0 & \\
\hline & 16000 & $15 \mathrm{~T}$ & 52 & 51 & 50 & 50 & 50.8 & 49.4 \\
\hline \multirow{3}{*}{$\begin{array}{c}\text { Greer W1 Heavy 4\% } \\
\text { VTM }\end{array}$} & 16000 & $16 \mathrm{~T}$ & 48 & 47 & 46 & 45 & 46.5 & \\
\hline & 16000 & $17 \mathrm{~T}$ & 48 & 47 & 46 & 46 & 46.8 & \\
\hline & 16000 & $18 \mathrm{~T}$ & 50 & 48 & 48 & 47 & 48.3 & 47.2 \\
\hline \multirow{3}{*}{$\begin{array}{l}\text { WV Paving } 12.5 \mathrm{~mm} \\
\text { Skid-RAP 4\% VTM }\end{array}$} & 16000 & $19 \mathrm{~T}$ & 52 & 51 & 50 & 50 & $\begin{array}{l}50.8 \\
\end{array}$ & \\
\hline & 16000 & $20 \mathrm{~T}$ & 52 & 51 & 50 & 49 & 50.5 & \\
\hline & 16000 & $21 \mathrm{~T}$ & 52 & 51 & 49 & 49 & 50.3 & $\begin{array}{l}50.5 \\
\end{array}$ \\
\hline \multirow{3}{*}{$\begin{array}{l}\text { WV Paving } 12.5 \mathrm{~mm} \\
\text { Skid-RAP 8\% VTM }\end{array}$} & 16000 & $22 \mathrm{~T}$ & 54 & 53 & 52 & 52 & 52.8 & \\
\hline & 16000 & $23 \mathrm{~T}$ & 54 & 53 & 52 & 51 & 52.5 & \\
\hline & 16000 & $24 \mathrm{~T}$ & 50 & 49 & 48 & 48 & 48.8 & 51.3 \\
\hline & & & & & & & & \\
\hline \multirow{3}{*}{$\begin{array}{c}\text { Greer W1 Heavy } 8 \% \\
\text { VTM }\end{array}$} & 32000 & $13 \mathrm{~T}$ & 47 & 47 & 46 & 45 & 46.3 & \\
\hline & 32000 & $14 \mathrm{~T}$ & 47 & 46 & 46 & 45 & 46.0 & \\
\hline & 32000 & $15 \mathrm{~T}$ & 51 & 49 & 48 & 48 & 49.0 & 47.1 \\
\hline \multirow{3}{*}{$\begin{array}{c}\text { Greer W1 Heavy } 4 \% \\
\text { VTM }\end{array}$} & 32000 & $16 \mathrm{~T}$ & 47 & 46 & 46 & 45 & 46.0 & \\
\hline & 32000 & $17 \mathrm{~T}$ & 46 & 45 & 44 & 44 & 44.8 & \\
\hline & 32000 & $18 \mathrm{~T}$ & 48 & 47 & 46 & 46 & 46.8 & 45.8 \\
\hline \multirow{3}{*}{$\begin{array}{l}\text { WV Paving 12.5mm } \\
\text { Skid-RAP 4\% VTM }\end{array}$} & 32000 & $19 \mathrm{~T}$ & 48 & 47 & 46 & 46 & 46.8 & \\
\hline & 32000 & $20 \mathrm{~T}$ & 48 & 48 & 47 & 46 & 47.3 & \\
\hline & 32000 & $21 \mathrm{~T}$ & 53 & 51 & 50 & 49 & 50.8 & 48.3 \\
\hline \multirow{2}{*}{$\begin{array}{l}\text { WV Paving } 12.5 \mathrm{~mm} \\
\text { Skid-RAP 8\% VTM }\end{array}$} & 32000 & $22 \mathrm{~T}$ & 53 & 51 & 50 & 49 & 50.8 & \\
\hline & 32000 & $23 \mathrm{~T}$ & 52 & 50 & 49 & 48 & 49.8 & \\
\hline
\end{tabular}




\begin{tabular}{|c|c|c|c|c|c|c|c|c|}
\hline \multirow{3}{*}{ Mix Type } & \multirow{2}{*}{$\begin{array}{c}\text { Number of } \\
\text { Wheel } \\
\text { Passes }\end{array}$} & \multirow[b]{2}{*}{ Specimen } & \multicolumn{6}{|c|}{ British Pendulum Number (BPN) } \\
\hline & & & $\begin{array}{c}\text { Trial } \\
1\end{array}$ & $\begin{array}{c}\text { Trial } \\
2\end{array}$ & $\begin{array}{c}\text { Trial } \\
\mathbf{3}\end{array}$ & $\begin{array}{c}\text { Trial } \\
4\end{array}$ & Average & $\begin{array}{c}\text { Mix } \\
\text { Average }\end{array}$ \\
\hline & 32000 & $24 \mathrm{~T}$ & 51 & 50 & 49 & 48 & 49.5 & 50.0 \\
\hline & & & & & & & & \\
\hline \multirow{3}{*}{$\begin{array}{c}\text { Greer W1 Heavy } 8 \% \\
\text { VTM }\end{array}$} & 48000 & $13 \mathrm{~T}$ & 45 & 43 & 42 & 42 & 43.0 & \\
\hline & 48000 & $14 \mathrm{~T}$ & 45 & 44 & 43 & 42 & 43.5 & \\
\hline & 48000 & $15 \mathrm{~T}$ & 47 & 45 & 44 & 43 & 44.8 & 43.8 \\
\hline \multirow{3}{*}{$\begin{array}{c}\text { Greer W1 Heavy } 4 \% \\
\text { VTM }\end{array}$} & 48000 & $16 \mathrm{~T}$ & 46 & 45 & 44 & 43 & 44.5 & \\
\hline & 48000 & $17 \mathrm{~T}$ & 45 & 43 & 43 & 42 & 43.3 & \\
\hline & 48000 & $18 \mathrm{~T}$ & 44 & 43 & 42 & 42 & 42.8 & 43.5 \\
\hline \multirow{3}{*}{$\begin{array}{l}\text { WV Paving } 12.5 \mathrm{~mm} \\
\text { Skid-RAP 4\% VTM }\end{array}$} & 48000 & $19 \mathrm{~T}$ & 48 & 47 & 45 & 45 & 46.3 & \\
\hline & 48000 & $20 \mathrm{~T}$ & 48 & 46 & 45 & 44 & 45.8 & \\
\hline & 48000 & $21 \mathrm{~T}$ & 50 & 48 & 47 & 46 & 47.8 & 46.6 \\
\hline \multirow{3}{*}{$\begin{array}{l}\text { WV Paving } 12.5 \mathrm{~mm} \\
\text { Skid-RAP 8\% VTM }\end{array}$} & 48000 & $22 \mathrm{~T}$ & 49 & 48 & 47 & 46 & 47.5 & \\
\hline & 48000 & $23 \mathrm{~T}$ & 48 & 47 & 45 & 45 & 46.3 & \\
\hline & 48000 & $24 \mathrm{~T}$ & 49 & 48 & 46 & 45 & 47.0 & 46.9 \\
\hline
\end{tabular}

\section{Trial 5: WVP 12.5mm SR and Greer W1H Specimens (Bottom}

\section{Surfaces)}

Table 49: BPN Measurements for Trial 5 WVP 12.5mm SR and Greer W1H (Bottom Surface) Specimens Polished with Hoosier R80 Tires at Low Toe for 64,000 Wheel Passes

\begin{tabular}{|c|c|c|c|c|c|c|c|c|}
\hline \multirow[b]{2}{*}{ Mix Type } & \multirow{2}{*}{$\begin{array}{c}\text { Number of } \\
\text { Wheel } \\
\text { Passes } \\
\end{array}$} & \multirow[b]{2}{*}{ Specimen } & \multicolumn{6}{|c|}{ British Pendulum Number (BPN) } \\
\hline & & & $\begin{array}{c}\text { Trial } \\
1\end{array}$ & $\begin{array}{c}\text { Trial } \\
2\end{array}$ & $\begin{array}{c}\text { Trial } \\
\mathbf{3}\end{array}$ & $\begin{array}{c}\text { Trial } \\
4\end{array}$ & Average & $\begin{array}{c}\text { Mix } \\
\text { Average }\end{array}$ \\
\hline \multirow{3}{*}{$\begin{array}{c}\text { Greer W1 Heavy } 8 \% \\
\text { VTM }\end{array}$} & 0 & 13B & 77 & 75 & 76 & 74 & 75.5 & \\
\hline & 0 & 14B & 77 & 76 & 75 & 74 & 75.5 & \\
\hline & 0 & $15 \mathrm{~B}$ & 76 & 76 & 75 & 74 & 75.3 & 75.4 \\
\hline \multirow{3}{*}{$\begin{array}{c}\text { Greer W1 Heavy } 4 \% \\
\text { VTM }\end{array}$} & 0 & $16 \mathrm{~B}$ & 77 & 77 & 77 & 75 & 76.5 & \\
\hline & 0 & 17B & 77 & 76 & 74 & 74 & 75.3 & \\
\hline & 0 & 18B & 77 & 77 & 76 & 75 & 76.3 & 76.0 \\
\hline \multirow{3}{*}{$\begin{array}{l}\text { WV Paving } 12.5 \mathrm{~mm} \\
\text { Skid-RAP 4\% VTM }\end{array}$} & 0 & 19B & 79 & 78 & 77 & 77 & 77.8 & \\
\hline & 0 & $20 \mathrm{~B}$ & 79 & 78 & 78 & 77 & 78.0 & \\
\hline & 0 & $21 \mathrm{~B}$ & 77 & 77 & 77 & 75 & 76.5 & 77.4 \\
\hline \multirow{3}{*}{$\begin{array}{l}\text { WV Paving } 12.5 \mathrm{~mm} \\
\text { Skid-RAP } 8 \% \text { VTM }\end{array}$} & 0 & $22 B$ & 80 & 81 & 80 & 79 & 80.0 & \\
\hline & 0 & $23 \mathrm{~B}$ & 76 & 75 & 74 & 74 & 74.8 & \\
\hline & 0 & $24 B$ & 79 & 79 & 77 & 77 & 78.0 & 77.6 \\
\hline
\end{tabular}




\begin{tabular}{|c|c|c|c|c|c|c|c|c|}
\hline \multirow[b]{2}{*}{ Mix Type } & \multirow{2}{*}{$\begin{array}{l}\text { Number of } \\
\text { Wheel } \\
\text { Passes }\end{array}$} & \multirow[b]{2}{*}{ Specimen } & \multicolumn{6}{|c|}{ British Pendulum Number (BPN) } \\
\hline & & & $\begin{array}{c}\text { Trial } \\
1\end{array}$ & $\begin{array}{c}\text { Trial } \\
2\end{array}$ & $\begin{array}{c}\text { Trial } \\
\mathbf{3}\end{array}$ & $\begin{array}{c}\text { Trial } \\
4\end{array}$ & Average & $\begin{array}{c}\text { Mix } \\
\text { Average }\end{array}$ \\
\hline \multirow{3}{*}{$\begin{array}{c}\text { Greer W1 Heavy } 8 \% \\
\text { VTM }\end{array}$} & 8000 & $13 \mathrm{~B}$ & 56 & 55 & 54 & 53 & 54.5 & \\
\hline & 8000 & 14B & 56 & 55 & 54 & 54 & 54.8 & \\
\hline & 8000 & $15 \mathrm{~B}$ & 55 & 54 & 54 & 53 & 54.0 & 54.4 \\
\hline \multirow{3}{*}{$\begin{array}{c}\text { Greer W1 Heavy } 4 \% \\
\text { VTM }\end{array}$} & 8000 & $16 \mathrm{~B}$ & 53 & 52 & 52 & 52 & 52.3 & \\
\hline & 8000 & 17B & 55 & 54 & 54 & 53 & 54.0 & \\
\hline & 8000 & 18B & 56 & 55 & 54 & 54 & 54.8 & 53.7 \\
\hline \multirow{3}{*}{$\begin{array}{l}\text { WV Paving } 12.5 \mathrm{~mm} \\
\text { Skid-RAP } 4 \% \text { VTM }\end{array}$} & 8000 & 19B & 57 & 56 & 56 & 55 & 56.0 & \\
\hline & 8000 & $20 \mathrm{~B}$ & 59 & 57 & 56 & 56 & 57.0 & \\
\hline & 8000 & 21B & 56 & 55 & 55 & 54 & 55.0 & 56.0 \\
\hline \multirow{3}{*}{$\begin{array}{l}\text { WV Paving } 12.5 \mathrm{~mm} \\
\text { Skid-RAP } 8 \% \text { VTM }\end{array}$} & 8000 & $22 B$ & 56 & 56 & 55 & 55 & 55.5 & \\
\hline & 8000 & $23 \mathrm{~B}$ & 56 & 55 & 54 & 54 & 54.8 & \\
\hline & 8000 & $24 B$ & 56 & 56 & 55 & 54 & 55.3 & 55.2 \\
\hline & & & & & & & & \\
\hline \multirow{3}{*}{$\begin{array}{c}\text { Greer W1 Heavy } 8 \% \\
\text { VTM }\end{array}$} & 16000 & 13B & 52 & 51 & 50 & 49 & \begin{tabular}{|l}
50.5 \\
\end{tabular} & \\
\hline & 16000 & 14B & 54 & 52 & 52 & 51 & 52.3 & \\
\hline & 16000 & $15 \mathrm{~B}$ & 50 & 50 & 48 & 48 & 49.0 & 50.6 \\
\hline \multirow{3}{*}{$\begin{array}{c}\text { Greer W1 Heavy } 4 \% \\
\text { VTM }\end{array}$} & 16000 & 16B & 51 & 50 & 49 & 49 & 49.8 & \\
\hline & 16000 & 17B & 53 & 52 & 51 & 50 & 51.5 & \\
\hline & 16000 & $18 \mathrm{~B}$ & 52 & 52 & 50 & 50 & 51.0 & 50.8 \\
\hline \multirow{3}{*}{$\begin{array}{l}\text { WV Paving } 12.5 \mathrm{~mm} \\
\text { Skid-RAP } 4 \% \text { VTM }\end{array}$} & 16000 & $19 B$ & 55 & 54 & 54 & 53 & 54.0 & \\
\hline & 16000 & $20 \mathrm{~B}$ & 54 & 53 & 51 & 51 & $\begin{array}{l}52.3 \\
\end{array}$ & \\
\hline & 16000 & $21 \mathrm{~B}$ & 52 & 51 & 50 & 49 & 50.5 & 52.3 \\
\hline \multirow{3}{*}{$\begin{array}{l}\text { WV Paving } 12.5 \mathrm{~mm} \\
\text { Skid-RAP } 8 \% \text { VTM }\end{array}$} & 16000 & $22 B$ & 54 & 53 & 52 & 52 & 52.8 & \\
\hline & 16000 & $23 \mathrm{~B}$ & 52 & 51 & 50 & 50 & 50.8 & \\
\hline & 16000 & $24 \mathrm{~B}$ & 53 & 52 & 51 & 50 & \begin{tabular}{|l|l}
51.5 \\
\end{tabular} & 51.7 \\
\hline & & & & & & & & \\
\hline \multirow{3}{*}{$\begin{array}{c}\text { Greer W1 Heavy } 8 \% \\
\text { VTM }\end{array}$} & 32000 & $13 \mathrm{~B}$ & 50 & 48 & 47 & 47 & 48.0 & \\
\hline & 32000 & 14B & 48 & 47 & 47 & 46 & 47.0 & \\
\hline & 32000 & $15 \mathrm{~B}$ & 48 & 47 & 46 & 46 & 46.8 & 47.3 \\
\hline \multirow{3}{*}{$\begin{array}{c}\text { Greer W1 Heavy } 4 \% \\
\text { VTM }\end{array}$} & 32000 & $16 \mathrm{~B}$ & 49 & 48 & 47 & 47 & 47.8 & \\
\hline & 32000 & 17B & 49 & 48 & 47 & 47 & 47.8 & \\
\hline & 32000 & 18B & 48 & 47 & 47 & 46 & 47.0 & 47.5 \\
\hline \multirow{3}{*}{$\begin{array}{l}\text { WV Paving } 12.5 \mathrm{~mm} \\
\text { Skid-RAP } 4 \% \text { VTM }\end{array}$} & 32000 & 19B & 51 & 49 & 49 & 48 & 49.3 & \\
\hline & 32000 & $20 \mathrm{~B}$ & 52 & 50 & 49 & 48 & 49.8 & \\
\hline & 32000 & $21 \mathrm{~B}$ & 50 & 49 & 48 & 47 & 48.5 & 49.2 \\
\hline \multirow{3}{*}{$\begin{array}{l}\text { WV Paving } 12.5 \mathrm{~mm} \\
\text { Skid-RAP } 8 \% \text { VTM }\end{array}$} & 32000 & $22 B$ & 50 & 47 & 47 & 46 & 47.5 & \\
\hline & 32000 & $23 B$ & 50 & 48 & 47 & 47 & 48.0 & \\
\hline & 32000 & $24 B$ & 48 & 47 & 46 & 46 & 46.8 & 47.4 \\
\hline
\end{tabular}




\begin{tabular}{|c|c|c|c|c|c|c|c|c|}
\hline \multirow[b]{2}{*}{ Mix Type } & \multirow{2}{*}{$\begin{array}{l}\text { Number of } \\
\text { Wheel } \\
\text { Passes }\end{array}$} & \multirow[b]{2}{*}{ Specimen } & \multicolumn{6}{|c|}{ British Pendulum Number (BPN) } \\
\hline & & & $\begin{array}{c}\text { Trial } \\
1\end{array}$ & $\begin{array}{c}\text { Trial } \\
2\end{array}$ & $\begin{array}{c}\text { Trial } \\
\mathbf{3}\end{array}$ & $\begin{array}{c}\text { Trial } \\
4\end{array}$ & Average & $\begin{array}{c}\text { Mix } \\
\text { Average }\end{array}$ \\
\hline \multirow{3}{*}{$\begin{array}{c}\text { Greer W1 Heavy } 8 \% \\
\text { VTM }\end{array}$} & 48000 & 13B & 46 & 44 & 43 & 42 & 43.8 & \\
\hline & 48000 & 14B & 43 & 43 & 42 & 42 & 42.5 & \\
\hline & 48000 & $15 \mathrm{~B}$ & 46 & 44 & 43 & 42 & 43.8 & 43.3 \\
\hline \multirow{3}{*}{$\begin{array}{c}\text { Greer W1 Heavy } 4 \% \\
\text { VTM }\end{array}$} & 48000 & $16 \mathrm{~B}$ & 45 & 43 & 42 & 42 & 43.0 & \\
\hline & 48000 & 17B & 44 & 43 & 42 & 42 & 42.8 & \\
\hline & 48000 & $18 \mathrm{~B}$ & 45 & 43 & 42 & 42 & 43.0 & 42.9 \\
\hline \multirow{3}{*}{$\begin{array}{l}\text { WV Paving } 12.5 \mathrm{~mm} \\
\text { Skid-RAP 4\% VTM }\end{array}$} & 48000 & 19B & 47 & 46 & 45 & 44 & 45.5 & \\
\hline & 48000 & $20 \mathrm{~B}$ & 50 & 48 & 47 & 45 & 47.5 & \\
\hline & 48000 & $21 \mathrm{~B}$ & 46 & 44 & 44 & 43 & 44.3 & 45.8 \\
\hline \multirow{3}{*}{$\begin{array}{l}\text { WV Paving } 12.5 \mathrm{~mm} \\
\text { Skid-RAP } 8 \% \text { VTM }\end{array}$} & 48000 & $22 B$ & 46 & 44 & 43 & 42 & 43.8 & \\
\hline & 48000 & $23 B$ & 45 & 44 & 43 & 42 & 43.5 & \\
\hline & 48000 & $24 B$ & 47 & 46 & 45 & 45 & 45.8 & 44.3 \\
\hline & & & & & & & & \\
\hline \multirow{3}{*}{$\begin{array}{c}\text { Greer W1 Heavy } 8 \% \\
\text { VTM }\end{array}$} & 64000 & $13 \mathrm{~B}$ & 42 & 40 & 39 & 39 & 40.0 & \\
\hline & 64000 & 14B & 42 & 41 & 40 & 39 & 40.5 & \\
\hline & 64000 & $15 \mathrm{~B}$ & 42 & 40 & 39 & 39 & 40.0 & 40.2 \\
\hline \multirow{3}{*}{$\begin{array}{c}\text { Greer W1 Heavy } 4 \% \\
\text { VTM }\end{array}$} & 64000 & $16 \mathrm{~B}$ & 41 & 39 & 39 & 37 & 39.0 & \\
\hline & 64000 & 17B & 40 & 38 & 37 & 37 & 38.0 & \\
\hline & 64000 & 18B & 40 & 38 & 38 & 37 & 38.3 & 38.4 \\
\hline \multirow{3}{*}{$\begin{array}{l}\text { WV Paving } 12.5 \mathrm{~mm} \\
\text { Skid-RAP } 4 \% \text { VTM }\end{array}$} & 64000 & $19 \mathrm{~B}$ & 44 & 43 & 42 & 41 & 42.5 & \\
\hline & 64000 & $20 \mathrm{~B}$ & 44 & 42 & 42 & 41 & 42.3 & \\
\hline & 64000 & $21 \mathrm{~B}$ & 42 & 40 & 39 & 39 & 40.0 & 41.6 \\
\hline \multirow{3}{*}{$\begin{array}{l}\text { WV Paving } 12.5 \mathrm{~mm} \\
\text { Skid-RAP } 8 \% \text { VTM }\end{array}$} & 64000 & $22 B$ & 43 & 41 & 40 & 39 & 40.8 & \\
\hline & 64000 & $23 \mathrm{~B}$ & 45 & 42 & 41 & 40 & 42.0 & \\
\hline & 64000 & $24 B$ & 44 & 42 & 41 & 41 & 42.0 & 41.6 \\
\hline
\end{tabular}

\section{Trial 6: JFA 12.5mm SR and WVP W1-RAP Specimens}

\section{(Bottom Surfaces)}

Table 50: BPN Measurements for Trial 6 JFA 12.5mm SR and WVP W1-RAP (Bottom Surface) Specimens Polished with Hoosier R80 Tires at Low Toe for 48,000 Wheel Passes

\begin{tabular}{|c|c|c|c|c|c|c|c|c|}
\hline \multirow{2}{*}{ Mix Type } & Number of & \multirow{2}{*}{$\begin{array}{c}\text { Wheel } \\
\text { Passes }\end{array}$} & Specimen & \multicolumn{6}{|c|}{ British Pendulum Number (BPN) } \\
\cline { 4 - 9 } & & Trial & Trial & Trial & Trial & Average & $\begin{array}{c}\text { Mix } \\
\text { Average }\end{array}$ \\
\hline JFA 12.5mm & 0 & 25B & 78 & 79 & 79 & 77 & $\mathbf{7 8 . 3}$ & \\
\cline { 4 - 9 } Skid-RAP 4\% & 0 & 26B & 75 & 76 & 76 & 76 & $\mathbf{7 5 . 8}$ & \\
\cline { 2 - 9 } VTM & 0 & $27 \mathrm{~B}$ & 78 & 75 & 76 & 80 & $\mathbf{7 7 . 3}$ & $\mathbf{7 7 . 1}$ \\
\hline
\end{tabular}




\begin{tabular}{|c|c|c|c|c|c|c|c|c|}
\hline \multirow[b]{2}{*}{ Mix Type } & \multirow{2}{*}{$\begin{array}{c}\text { Number of } \\
\text { Wheel } \\
\text { Passes } \\
\end{array}$} & \multirow[b]{2}{*}{ Specimen } & \multicolumn{6}{|c|}{ British Pendulum Number (BPN) } \\
\hline & & & $\begin{array}{c}\text { Trial } \\
1 \\
\end{array}$ & $\begin{array}{c}\text { Trial } \\
2 \\
\end{array}$ & $\begin{array}{c}\text { Trial } \\
\mathbf{3} \\
\end{array}$ & $\begin{array}{c}\text { Trial } \\
4 \\
\end{array}$ & Average & $\begin{array}{c}\text { Mix } \\
\text { Average } \\
\end{array}$ \\
\hline \multirow{3}{*}{$\begin{array}{c}\text { JFA } 12.5 \mathrm{~mm} \\
\text { Skid-RAP } 8 \% \\
\text { VTM }\end{array}$} & 0 & $28 \mathrm{~B}$ & 73 & 74 & 73 & 73 & 73.3 & \\
\hline & 0 & 29B & 77 & 77 & 80 & 80 & 78.5 & \\
\hline & 0 & $30 \mathrm{~B}$ & 76 & 79 & 76 & 76 & 76.8 & 76.2 \\
\hline \multirow{3}{*}{$\begin{array}{l}\text { WV Paving W1- } \\
\text { RAP 4\% VTM }\end{array}$} & 0 & $31 \mathrm{~B}$ & 85 & 86 & 87 & 87 & 86.3 & \\
\hline & 0 & $32 \mathrm{~B}$ & 81 & 85 & 85 & 85 & 84.0 & \\
\hline & 0 & $33 \mathrm{~B}$ & 86 & 86 & 86 & 85 & 85.8 & 85.3 \\
\hline \multirow{3}{*}{$\begin{array}{l}\text { WV Paving W1- } \\
\text { RAP 8\% VTM }\end{array}$} & 0 & 34B & 85 & 86 & 85 & 84 & 85.0 & \\
\hline & 0 & $35 \mathrm{~B}$ & 83 & 82 & 82 & 81 & 82.0 & \\
\hline & 0 & $36 \mathrm{~B}$ & 87 & 86 & 85 & 86 & 86.0 & 84.3 \\
\hline \multirow{3}{*}{$\begin{array}{c}\text { JFA } 12.5 \mathrm{~mm} \\
\text { Skid-RAP } 4 \% \\
\text { VTM }\end{array}$} & 8000 & $25 \mathrm{~B}$ & 58 & 56 & 56 & 56 & 565 & \\
\hline & 8000 & $\frac{25 D}{26 B}$ & 58 & 57 & 57 & 56 & \begin{tabular}{|l|}
50.5 \\
57.0
\end{tabular} & \\
\hline & 8000 & $27 \mathrm{~B}$ & 58 & 56 & 56 & 55 & 56.3 & 56.6 \\
\hline \multirow{3}{*}{$\begin{array}{c}\text { JFA } 12.5 \mathrm{~mm} \\
\text { Skid-RAP } 8 \% \\
\text { VTM }\end{array}$} & 8000 & $28 \mathrm{~B}$ & 59 & 57 & 57 & 56 & 57.3 & \\
\hline & 8000 & 29B & 56 & 55 & 54 & 54 & 54.8 & \\
\hline & 8000 & $30 \mathrm{~B}$ & 61 & 59 & 58 & 58 & 59.0 & 57.0 \\
\hline \multirow{3}{*}{$\begin{array}{l}\text { WV Paving W1- } \\
\text { RAP 4\% VTM }\end{array}$} & 8000 & $31 \mathrm{~B}$ & 63 & 62 & 62 & 61 & 62.0 & \\
\hline & 8000 & $32 \mathrm{~B}$ & 63 & 62 & 61 & 60 & 61.5 & \\
\hline & 8000 & $33 \mathrm{~B}$ & 63 & 62 & 61 & 61 & 61.8 & 61.8 \\
\hline \multirow{3}{*}{$\begin{array}{l}\text { WV Paving W1- } \\
\text { RAP 8\% VTM }\end{array}$} & 8000 & $34 \mathrm{~B}$ & 64 & 63 & 61 & 61 & 62.3 & \\
\hline & 8000 & $35 \mathrm{~B}$ & 63 & 62 & 61 & 60 & 61.5 & \\
\hline & 8000 & $36 \mathrm{~B}$ & 63 & 61 & 60 & 60 & 61.0 & 61.6 \\
\hline \multirow{3}{*}{$\begin{array}{c}\text { JFA } 12.5 \mathrm{~mm} \\
\text { Skid-RAP } 4 \% \\
\text { VTM }\end{array}$} & 16000 & $25 \mathrm{~B}$ & 53 & 52 & 51 & 51 & 51.8 & \\
\hline & 16000 & $26 B$ & 52 & 51 & 51 & 50 & 51.0 & \\
\hline & 16000 & $27 \mathrm{~B}$ & 54 & 52 & 52 & 51 & 52.3 & 51.7 \\
\hline \multirow{3}{*}{$\begin{array}{c}\text { JFA } 12.5 \mathrm{~mm} \\
\text { Skid-RAP } 8 \% \\
\text { VTM }\end{array}$} & 16000 & $28 \mathrm{~B}$ & 53 & 52 & 51 & 51 & 51.8 & \\
\hline & 16000 & $29 B$ & 54 & 53 & 52 & 51 & 52.5 & \\
\hline & 16000 & $30 \mathrm{~B}$ & 55 & 54 & 53 & 53 & 53.8 & 53.1 \\
\hline \multirow{3}{*}{$\begin{array}{l}\text { WV Paving W1- } \\
\text { RAP 4\% VTM }\end{array}$} & 16000 & $31 \mathrm{~B}$ & 56 & 55 & 54 & 53 & 54.5 & \\
\hline & 16000 & $32 B$ & 57 & 56 & 54 & 54 & 55.3 & \\
\hline & 16000 & $33 \mathrm{~B}$ & 58 & 56 & 55 & 54 & 55.8 & 55.2 \\
\hline \multirow{3}{*}{$\begin{array}{l}\text { WV Paving W1- } \\
\text { RAP 8\% VTM }\end{array}$} & 16000 & $34 \mathrm{~B}$ & 59 & 56 & 56 & 55 & 56.5 & \\
\hline & 16000 & $35 \mathrm{~B}$ & 59 & 56 & 56 & 56 & $\begin{array}{l}56.8 \\
\end{array}$ & \\
\hline & 16000 & $36 \mathrm{~B}$ & 58 & 57 & 56 & 56 & \begin{tabular}{|l}
56.8 \\
\end{tabular} & \begin{tabular}{|l}
56.7 \\
\end{tabular} \\
\hline \multirow{4}{*}{$\begin{array}{c}\text { JFA } 12.5 \mathrm{~mm} \\
\text { Skid-RAP } 4 \% \\
\text { VTM }\end{array}$} & 32000 & $25 \mathrm{~B}$ & 50 & 48 & 48 & 47 & 48.3 & \\
\hline & 32000 & $26 \mathrm{~B}$ & 52 & 50 & 49 & 48 & 49.8 & \\
\hline & 32000 & $27 \mathrm{~B}$ & 52 & 50 & 50 & 49 & 50.3 & 49.4 \\
\hline & 32000 & $28 \mathrm{~B}$ & 52 & 50 & 49 & 49 & 50.0 & \\
\hline
\end{tabular}




\begin{tabular}{|c|c|c|c|c|c|c|c|c|}
\hline \multirow[b]{2}{*}{ Mix Type } & \multirow{2}{*}{$\begin{array}{c}\text { Number of } \\
\text { Wheel } \\
\text { Passes } \\
\end{array}$} & \multirow[b]{2}{*}{ Specimen } & \multicolumn{6}{|c|}{ British Pendulum Number (BPN) } \\
\hline & & & $\begin{array}{c}\text { Trial } \\
1\end{array}$ & $\begin{array}{c}\text { Trial } \\
2\end{array}$ & $\begin{array}{c}\text { Trial } \\
\mathbf{3}\end{array}$ & $\begin{array}{c}\text { Trial } \\
4\end{array}$ & Average & $\begin{array}{c}\text { Mix } \\
\text { Average }\end{array}$ \\
\hline \multirow{2}{*}{$\begin{array}{c}\text { JFA } 12.5 \mathrm{~mm} \\
\text { Skid-RAP } 8 \% \\
\text { VTM }\end{array}$} & 32000 & $29 B$ & 52 & 51 & 50 & 49 & 50.5 & \\
\hline & 32000 & $30 \mathrm{~B}$ & 54 & 53 & 53 & 52 & 53.0 & 51.2 \\
\hline \multirow{3}{*}{$\begin{array}{l}\text { WV Paving W1- } \\
\text { RAP 4\% VTM }\end{array}$} & 32000 & $31 \mathrm{~B}$ & 55 & 53 & 53 & 52 & 53.3 & \\
\hline & 32000 & 32B & 54 & 52 & 52 & 51 & 52.3 & \\
\hline & 32000 & $33 \mathrm{~B}$ & 54 & 53 & 52 & 51 & 52.5 & 52.7 \\
\hline \multirow{3}{*}{$\begin{array}{l}\text { WV Paving W1- } \\
\text { RAP 8\% VTM }\end{array}$} & 32000 & 34B & 55 & 53 & 53 & 52 & 53.3 & \\
\hline & 32000 & $35 \mathrm{~B}$ & 55 & 54 & 53 & 52 & 53.5 & \\
\hline & 32000 & $36 \mathrm{~B}$ & 56 & 55 & 53 & 53 & 54.3 & 53.7 \\
\hline \multirow{4}{*}{$\begin{array}{c}\text { JFA } 12.5 \mathrm{~mm} \\
\text { Skid-RAP } 4 \% \\
\text { VTM }\end{array}$} & & & & & & & 17 - & \\
\hline & 48000 & $25 \mathrm{~B}$ & 49 & 48 & 47 & 46 & 47.5 & \\
\hline & 48000 & $26 \mathrm{~B}$ & 49 & 47 & 47 & 46 & 47.3 & \\
\hline & 48000 & $27 \mathrm{~B}$ & 51 & 49 & 48 & 47 & 48.8 & 47.8 \\
\hline \multirow{3}{*}{$\begin{array}{c}\text { JFA } 12.5 \mathrm{~mm} \\
\text { Skid-RAP } 8 \% \\
\text { VTM }\end{array}$} & 48000 & $28 \mathrm{~B}$ & 52 & 50 & 49 & 48 & 49.8 & \\
\hline & 48000 & $29 B$ & 51 & 50 & 48 & 47 & 49.0 & \\
\hline & 48000 & $30 \mathrm{~B}$ & 52 & 50 & 48 & 47 & 49.3 & 49.3 \\
\hline \multirow{3}{*}{$\begin{array}{l}\text { WV Paving W1- } \\
\text { RAP 4\% VTM }\end{array}$} & 48000 & $31 \mathrm{~B}$ & 53 & 51 & 50 & 49 & 50.8 & \\
\hline & 48000 & $32 \mathrm{~B}$ & 51 & 49 & 48 & 47 & 48.8 & \\
\hline & 48000 & $33 \mathrm{~B}$ & 52 & 51 & 50 & 49 & 50.5 & $\begin{array}{l}50.0 \\
\end{array}$ \\
\hline \multirow{3}{*}{$\begin{array}{l}\text { WV Paving W1- } \\
\text { RAP 8\% VTM }\end{array}$} & 48000 & $34 \mathrm{~B}$ & 53 & 51 & 50 & 49 & $\begin{array}{l}50.8 \\
\end{array}$ & \\
\hline & 48000 & $35 \mathrm{~B}$ & 53 & 51 & 49 & 48 & 50.3 & \\
\hline & 48000 & $36 \mathrm{~B}$ & 51 & 49 & 48 & 47 & 48.8 & 49.9 \\
\hline
\end{tabular}

\section{Trial 7: JFA 12.5mm SR and WVP W1-RAP Specimens (Top Surfaces)}

Table 51: BPN Measurements for Trial 7 JFA 12.5mm SR and WVP W1-RAP (Top Surface) Specimens Polished with Hoosier R80 Tires at High Toe for 48,000 Wheel Passes

\begin{tabular}{|c|c|c|c|c|c|c|c|c|}
\hline \multirow[b]{2}{*}{ Mix Type } & \multirow{2}{*}{$\begin{array}{c}\text { Number of } \\
\text { Wheel } \\
\text { Passes }\end{array}$} & \multirow[b]{2}{*}{ Specimen } & \multicolumn{6}{|c|}{ British Pendulum Number (BPN) } \\
\hline & & & $\begin{array}{c}\text { Trial } \\
1\end{array}$ & $\begin{array}{c}\text { Trial } \\
2\end{array}$ & $\begin{array}{c}\text { Trial } \\
3\end{array}$ & $\begin{array}{c}\text { Trial } \\
4\end{array}$ & Average & $\begin{array}{c}\text { Mix } \\
\text { Average }\end{array}$ \\
\hline \multirow{3}{*}{$\begin{array}{c}\text { JFA } 12.5 \mathrm{~mm} \\
\text { Skid-RAP } 4 \% \\
\text { VTM }\end{array}$} & 0 & $25 \mathrm{~T}$ & 74 & 74 & 73 & 73 & 73.5 & \\
\hline & 0 & $26 \mathrm{~T}$ & 77 & 76 & 76 & 75 & 76.0 & \\
\hline & 0 & $27 \mathrm{~T}$ & 74 & 73 & 72 & 71 & 72.5 & 74.0 \\
\hline \multirow{3}{*}{$\begin{array}{c}\text { JFA } 12.5 \mathrm{~mm} \\
\text { Skid-RAP } 8 \% \\
\text { VTM }\end{array}$} & 0 & $28 \mathrm{~T}$ & 80 & 79 & 77 & 78 & 78.5 & \\
\hline & 0 & $29 \mathrm{~T}$ & 74 & 73 & 73 & 73 & 73.3 & \\
\hline & 0 & $30 \mathrm{~T}$ & 76 & 74 & 75 & 75 & 75.0 & 75.6 \\
\hline \multirow{2}{*}{$\begin{array}{l}\text { WV Paving W1- } \\
\text { RAP 4\% VTM }\end{array}$} & 0 & $31 \mathrm{~T}$ & 81 & 80 & 80 & 79 & 80 & \\
\hline & 0 & $32 \mathrm{~T}$ & 80 & 82 & 82 & 83 & 81.8 & \\
\hline
\end{tabular}




\begin{tabular}{|c|c|c|c|c|c|c|c|c|}
\hline \multirow{3}{*}{ Mix Type } & \multirow{2}{*}{$\begin{array}{c}\text { Number of } \\
\text { Wheel } \\
\text { Passes } \\
\end{array}$} & \multirow[b]{2}{*}{ Specimen } & \multicolumn{6}{|c|}{ British Pendulum Number (BPN) } \\
\hline & & & $\begin{array}{c}\text { Trial } \\
1\end{array}$ & $\begin{array}{c}\text { Trial } \\
2\end{array}$ & $\begin{array}{c}\text { Trial } \\
\mathbf{3}\end{array}$ & $\begin{array}{c}\text { Trial } \\
4\end{array}$ & Average & $\begin{array}{c}\text { Mix } \\
\text { Average }\end{array}$ \\
\hline & 0 & $33 \mathrm{~T}$ & 77 & 74 & 74 & 73 & 74.5 & 78.8 \\
\hline \multirow{3}{*}{$\begin{array}{l}\text { WV Paving W1- } \\
\text { RAP 8\% VTM }\end{array}$} & 0 & $34 \mathrm{~T}$ & 82 & 82 & 80 & 80 & 81.0 & \\
\hline & 0 & $35 \mathrm{~T}$ & 81 & 86 & 81 & 81 & 82.3 & \\
\hline & 0 & $36 \mathrm{~T}$ & 79 & 82 & 81 & 81 & 80.8 & 81.3 \\
\hline \multirow{4}{*}{$\begin{array}{c}\text { JFA } 12.5 \mathrm{~mm} \\
\text { Skid-RAP } 4 \% \\
\text { VTM }\end{array}$} & & & & & & & & \\
\hline & 8000 & $25 \mathrm{~T}$ & 52 & 51 & 50 & 50 & 50.8 & \\
\hline & 8000 & $26 \mathrm{~T}$ & 55 & 53 & 53 & 52 & 53.3 & \\
\hline & 8000 & $27 \mathrm{~T}$ & 53 & 52 & 52 & 51 & 52.0 & 52.0 \\
\hline \multirow{3}{*}{$\begin{array}{c}\text { JFA } 12.5 \mathrm{~mm} \\
\text { Skid-RAP } 8 \% \\
\text { VTM } \\
\end{array}$} & 8000 & $28 \mathrm{~T}$ & 53 & 51 & 51 & 50 & 51.3 & \\
\hline & 8000 & $29 \mathrm{~T}$ & 53 & 52 & 52 & 51 & 52.0 & \\
\hline & 8000 & $30 \mathrm{~T}$ & 53 & 52 & 51 & 51 & 51.8 & 51.7 \\
\hline \multirow{3}{*}{$\begin{array}{l}\text { WV Paving W1- } \\
\text { RAP 4\% VTM }\end{array}$} & 8000 & $31 \mathrm{~T}$ & 57 & 56 & 55 & 54 & 55.5 & \\
\hline & 8000 & $32 \mathrm{~T}$ & 57 & 56 & 55 & 54 & 55.5 & \\
\hline & 8000 & $33 \mathrm{~T}$ & 57 & 55 & 54 & 54 & 55.0 & 55.3 \\
\hline \multirow{3}{*}{$\begin{array}{l}\text { WV Paving W1- } \\
\text { RAP } 8 \% \text { VTM }\end{array}$} & 8000 & $34 \mathrm{~T}$ & 55 & 54 & 53 & 53 & 53.8 & \\
\hline & 8000 & $35 \mathrm{~T}$ & 57 & 56 & 55 & 55 & 55.8 & \\
\hline & 8000 & $36 \mathrm{~T}$ & 53 & 55 & 55 & 54 & 54.3 & 54.6 \\
\hline & & & & & & & & \\
\hline \multirow{3}{*}{$\begin{array}{c}\text { JFA } 12.5 \mathrm{~mm} \\
\text { Skid-RAP } 4 \% \\
\text { VTM }\end{array}$} & 16000 & $25 \mathrm{~T}$ & 48 & 47 & 47 & 46 & 47.0 & \\
\hline & 16000 & $26 \mathrm{~T}$ & 48 & 47 & 47 & 46 & 47.0 & \\
\hline & 16000 & $27 \mathrm{~T}$ & 50 & 48 & 48 & 47 & 48.3 & 47.4 \\
\hline \multirow{3}{*}{$\begin{array}{c}\text { JFA } 12.5 \mathrm{~mm} \\
\text { Skid-RAP } 8 \% \\
\text { VTM }\end{array}$} & 16000 & $28 \mathrm{~T}$ & 48 & 47 & 47 & 46 & 47.0 & \\
\hline & 16000 & $29 \mathrm{~T}$ & 49 & 47 & 47 & 47 & 47.5 & \\
\hline & 16000 & $30 \mathrm{~T}$ & 49 & 47 & 47 & 47 & 47.5 & 48.6 \\
\hline \multirow{3}{*}{$\begin{array}{l}\text { WV Paving W1- } \\
\text { RAP 4\% VTM }\end{array}$} & 16000 & $31 \mathrm{~T}$ & 54 & 53 & 52 & 51 & 52.5 & \\
\hline & 16000 & $32 \mathrm{~T}$ & 52 & 50 & 49 & 48 & 49.8 & \\
\hline & 16000 & $33 \mathrm{~T}$ & 53 & 51 & 51 & 49 & 51.0 & 51.1 \\
\hline \multirow{3}{*}{$\begin{array}{l}\text { WV Paving W1- } \\
\text { RAP 8\% VTM }\end{array}$} & 16000 & $34 \mathrm{~T}$ & 51 & 50 & 48 & 47 & 49.0 & \\
\hline & 16000 & $35 \mathrm{~T}$ & 56 & 51 & 53 & 53 & 53.3 & \\
\hline & 16000 & $36 \mathrm{~T}$ & 52 & 50 & 49 & 48 & 49.8 & 50.7 \\
\hline \multirow{3}{*}{$\begin{array}{c}\text { JFA } 12.5 \mathrm{~mm} \\
\text { Skid-RAP } 4 \% \\
\text { VTM }\end{array}$} & 32000 & $25 \mathrm{~T}$ & 41 & 39 & 39 & 38 & 39.3 & \\
\hline & 32000 & $26 \mathrm{~T}$ & 42 & 41 & 41 & 40 & 41.0 & \\
\hline & 32000 & $27 \mathrm{~T}$ & 42 & 41 & 41 & 40 & 41.0 & 40.4 \\
\hline \multirow{3}{*}{$\begin{array}{c}\text { JFA } 12.5 \mathrm{~mm} \\
\text { Skid-RAP } 8 \% \\
\text { VTM }\end{array}$} & 32000 & $28 \mathrm{~T}$ & 40 & 40 & 39 & 39 & 39.5 & \\
\hline & 32000 & $29 \mathrm{~T}$ & 42 & 41 & 40 & 40 & 40.8 & \\
\hline & 32000 & $30 \mathrm{~T}$ & 41 & 41 & 40 & 40 & 40.5 & 40.3 \\
\hline \multirow{3}{*}{$\begin{array}{l}\text { WV Paving W1- } \\
\text { RAP 4\% VTM }\end{array}$} & 32000 & $31 \mathrm{~T}$ & 42 & 40 & 40 & 40 & 40.5 & \\
\hline & 32000 & $32 \mathrm{~T}$ & 43 & 42 & 41 & 41 & 41.8 & \\
\hline & 32000 & $33 \mathrm{~T}$ & 43 & 42 & 41 & 41 & 41.8 & 41.3 \\
\hline
\end{tabular}




\begin{tabular}{|c|c|c|c|c|c|c|c|c|}
\hline \multirow[b]{2}{*}{ Mix Type } & \multirow{2}{*}{$\begin{array}{c}\text { Number of } \\
\text { Wheel } \\
\text { Passes }\end{array}$} & \multirow[b]{2}{*}{ Specimen } & \multicolumn{6}{|c|}{ British Pendulum Number (BPN) } \\
\hline & & & $\begin{array}{c}\text { Trial } \\
1\end{array}$ & $\begin{array}{c}\text { Trial } \\
2\end{array}$ & $\begin{array}{c}\text { Trial } \\
\mathbf{3}\end{array}$ & $\begin{array}{c}\text { Trial } \\
4\end{array}$ & Average & $\begin{array}{c}\text { Mix } \\
\text { Average }\end{array}$ \\
\hline \multirow{3}{*}{$\begin{array}{l}\text { WV Paving W1- } \\
\text { RAP 8\% VTM }\end{array}$} & 32000 & $34 \mathrm{~T}$ & 42 & 41 & 41 & 40 & 41.0 & \\
\hline & 32000 & $35 \mathrm{~T}$ & 44 & 43 & 42 & 41 & 42.5 & \\
\hline & 32000 & $36 \mathrm{~T}$ & 42 & 41 & 41 & 41 & 41.3 & 41.6 \\
\hline & & & & & & & & \\
\hline \multirow{3}{*}{$\begin{array}{c}\text { JFA } 12.5 \mathrm{~mm} \\
\text { Skid-RAP } 4 \% \\
\text { VTM }\end{array}$} & 48000 & $25 \mathrm{~T}$ & 42 & 41 & 40 & 38 & 40.3 & \\
\hline & 48000 & $26 \mathrm{~T}$ & 41 & 41 & 40 & 38 & 40.0 & \\
\hline & 48000 & $27 \mathrm{~T}$ & 42 & 41 & 41 & 40 & 41.0 & 40.4 \\
\hline \multirow{3}{*}{$\begin{array}{c}\text { JFA } 12.5 \mathrm{~mm} \\
\text { Skid-RAP } 8 \% \\
\text { VTM }\end{array}$} & 48000 & $28 \mathrm{~T}$ & 42 & 41 & 40 & 39 & 40.5 & \\
\hline & 48000 & $29 \mathrm{~T}$ & 44 & 42 & 41 & 40 & 41.8 & \\
\hline & 48000 & $30 \mathrm{~T}$ & 42 & 41 & 40 & 39 & 40.5 & 40.9 \\
\hline \multirow{3}{*}{$\begin{array}{l}\text { WV Paving W1- } \\
\text { RAP 4\% VTM }\end{array}$} & 48000 & $31 \mathrm{~T}$ & 42 & 41 & 40 & 39 & 40.5 & \\
\hline & 48000 & $32 \mathrm{~T}$ & 43 & 41 & 40 & 39 & 40.8 & \\
\hline & 48000 & $33 \mathrm{~T}$ & 43 & 42 & 41 & 40 & 41.5 & 40.9 \\
\hline \multirow{3}{*}{$\begin{array}{l}\text { WV Paving W1- } \\
\text { RAP 8\% VTM }\end{array}$} & 48000 & $34 \mathrm{~T}$ & 43 & 42 & 41 & 40 & 41.5 & \\
\hline & 48000 & $35 \mathrm{~T}$ & 42 & 41 & 41 & 40 & 41.0 & \\
\hline & 48000 & $36 \mathrm{~T}$ & 42 & 41 & 39 & 38 & 40.0 & 40.8 \\
\hline
\end{tabular}

\section{Trial 8: JFA 12.5mm SR Laboratory Compacted and Field Core Specimens}

Table 52: BPN Measurements for Trial 8 JFA 12.5mm SR Laboratory Compacted and Field Core Specimens Polished with Hoosier R80 Tires at High Toe for 48,000 Wheel Passes

\begin{tabular}{|c|c|c|c|c|c|c|c|c|}
\hline \multirow{2}{*}{ Mix Type } & \multirow{2}{*}{$\begin{array}{c}\text { Number of } \\
\text { Wheel Passes }\end{array}$} & \multirow{2}{*}{ Specimen } & \multirow{2}{*}{$\begin{array}{c}\text { Specimen } \\
\text { Type }\end{array}$} & \multicolumn{5}{|c|}{ British Pendulum Number (BPN) } \\
\hline & & & & Trial 1 & Trial 2 & Trial 3 & Trial 4 & Average \\
\hline \multirow{12}{*}{$\begin{array}{l}\text { JFA } 12.5 \mathrm{~mm} \\
\text { Skid-RAP }\end{array}$} & 0 & $1 \mathrm{~L}$ & Lab & 60 & 60 & 59 & 58 & 59.3 \\
\hline & 0 & $1 \mathrm{~F}$ & Field & 63 & 61 & 61 & 59 & 61.0 \\
\hline & 0 & $2 \mathrm{~L}$ & Lab & 57 & 56 & 54 & 54 & 55.25 \\
\hline & 0 & $2 \mathrm{~F}$ & Field & 67 & 66 & 66 & 65 & 66.0 \\
\hline & 0 & $3 \mathrm{~L}$ & Lab & 63 & 62 & 60 & 59 & 61.0 \\
\hline & 0 & $3 \mathrm{~F}$ & Field & 75 & 73 & 72 & 71 & 72.8 \\
\hline & 0 & $4 \mathrm{~L}$ & Lab & 56 & 55 & 53 & 53 & 54.25 \\
\hline & 0 & $4 \mathrm{~F}$ & Field & 55 & 53 & 53 & 52 & 53.3 \\
\hline & 0 & $5 \mathrm{~L}$ & $\mathrm{Lab}$ & 62 & 60 & 59 & 58 & 59.8 \\
\hline & 0 & $5 \mathrm{~F}$ & Field & 56 & 54 & 53 & 52 & 53.8 \\
\hline & 0 & $6 \mathrm{~L}$ & Lab & 70 & 67 & 66 & 65 & 67.0 \\
\hline & 0 & $6 \mathrm{~F}$ & Field & 72 & 71 & 69 & 67 & 69.8 \\
\hline
\end{tabular}




\begin{tabular}{|c|c|c|c|c|c|c|c|c|}
\hline \multirow{2}{*}{ Mix Type } & \multirow{2}{*}{$\begin{array}{c}\text { Number of } \\
\text { Wheel Passes }\end{array}$} & \multirow{2}{*}{ Specimen } & \multirow{2}{*}{$\begin{array}{c}\text { Specimen } \\
\text { Type }\end{array}$} & \multicolumn{5}{|c|}{ British Pendulum Number (BPN) } \\
\hline & & & & Trial 1 & Trial 2 & Trial 3 & Trial 4 & Average \\
\hline \multirow{13}{*}{$\begin{array}{l}\text { JFA 12.5mm } \\
\text { Skid-RAP }\end{array}$} & & & & & & & & \\
\hline & 8000 & $1 \mathrm{~L}$ & $\mathrm{Lab}$ & 47 & 46 & 45 & 45 & 45.8 \\
\hline & 8000 & $1 \mathrm{~F}$ & Field & 48 & 47 & 46 & 46 & 46.8 \\
\hline & 8000 & $2 \mathrm{~L}$ & Lab & 48 & 47 & 46 & 45 & 46.5 \\
\hline & 8000 & $2 \mathrm{~F}$ & Field & 48 & 47 & 47 & 47 & 47.3 \\
\hline & 8000 & $3 \mathrm{~L}$ & $\mathrm{Lab}$ & 49 & 47 & 47 & 47 & 47.5 \\
\hline & 8000 & $3 \mathrm{~F}$ & Field & 49 & 47 & 47 & 47 & 47.5 \\
\hline & 8000 & $4 \mathrm{~L}$ & Lab & 50 & 48 & 48 & 47 & 48.3 \\
\hline & 8000 & $4 \mathrm{~F}$ & Field & 46 & 45 & 45 & 44 & 45.0 \\
\hline & 8000 & $5 \mathrm{~L}$ & $\mathrm{Lab}$ & 49 & 48 & 47 & 47 & 47.8 \\
\hline & 8000 & $5 \mathrm{~F}$ & Field & 48 & 47 & 46 & 46 & 46.8 \\
\hline & 8000 & $6 \mathrm{~L}$ & Lab & 49 & 48 & 47 & 47 & 47.8 \\
\hline & 8000 & $6 \mathrm{~F}$ & Field & 50 & 47 & 47 & 47 & 47.8 \\
\hline & & & & & & & & \\
\hline \multirow{12}{*}{$\begin{array}{c}\text { JFA } 12.5 \mathrm{~mm} \\
\text { Skid-RAP }\end{array}$} & 24000 & $1 \mathrm{~L}$ & Lab & 46 & 44 & 43 & 43 & 44 \\
\hline & 24000 & $1 \mathrm{~F}$ & Field & 46 & 45 & 43 & 43 & 44.25 \\
\hline & 24000 & $2 \mathrm{~L}$ & Lab & 43 & 42 & 42 & 41 & 42.0 \\
\hline & 24000 & $2 \mathrm{~F}$ & Field & 46 & 44 & 43 & 42 & 43.75 \\
\hline & 24000 & $3 \mathrm{~L}$ & $\mathrm{Lab}$ & 45 & 43 & 42 & 42 & 43.0 \\
\hline & 24000 & $3 \mathrm{~F}$ & Field & 45 & 43 & 43 & 42 & 43.3 \\
\hline & 24000 & $4 \mathrm{~L}$ & $\mathrm{Lab}$ & 46 & 44 & 43 & 42 & 43.8 \\
\hline & 24000 & $4 \mathrm{~F}$ & Field & 45 & 43 & 42 & 42 & 43.0 \\
\hline & 24000 & $5 \mathrm{~L}$ & $\mathrm{Lab}$ & 46 & 45 & 45 & 44 & 45.0 \\
\hline & 24000 & $5 \mathrm{~F}$ & Field & 45 & 44 & 43 & 42 & 43.5 \\
\hline & 24000 & $6 \mathrm{~L}$ & Lab & 48 & 47 & 46 & 45 & 46.5 \\
\hline & 24000 & $6 \mathrm{~F}$ & Field & 46 & 45 & 43 & 43 & 44.3 \\
\hline & & & & & & & & \\
\hline \multirow{12}{*}{$\begin{array}{c}\text { JFA } 12.5 \mathrm{~mm} \\
\text { Skid-RAP }\end{array}$} & 48000 & $1 \mathrm{~L}$ & Lab & 44 & 42 & 41 & 41 & 42 \\
\hline & 48000 & $1 \mathrm{~F}$ & Field & 46 & 44 & 42 & 42 & 43.5 \\
\hline & 48000 & $2 \mathrm{~L}$ & Lab & 42 & 41 & 41 & 39 & 40.75 \\
\hline & 48000 & $2 \mathrm{~F}$ & Field & 46 & 44 & 43 & 42 & 43.75 \\
\hline & 48000 & $3 \mathrm{~L}$ & Lab & 44 & 42 & 42 & 41 & 42.25 \\
\hline & 48000 & $3 \mathrm{~F}$ & Field & 45 & 43 & 42 & 41 & 42.75 \\
\hline & 48000 & $4 L$ & Lab & 46 & 44 & 42 & 42 & 43.5 \\
\hline & 48000 & $4 \mathrm{~F}$ & Field & 44 & 42 & 42 & 40 & 42 \\
\hline & 48000 & $5 \mathrm{~L}$ & $\mathrm{Lab}$ & 45 & 43 & 41 & 41 & 42.5 \\
\hline & 48000 & $5 \mathrm{~F}$ & Field & 46 & 44 & 42 & 42 & 43.5 \\
\hline & 48000 & $6 \mathrm{~L}$ & Lab & 44 & 43 & 42 & 41 & 42.5 \\
\hline & 48000 & $6 \mathrm{~F}$ & Field & 45 & 43 & 42 & 41 & 42.75 \\
\hline
\end{tabular}




\section{Trial 9: JFA 12.5mm SR Field Core Specimens and Corresponding Field Measurements}

Table 53: BPN Measurements for Trial 9 JFA 12.5mm SR Field Core Specimens Polished with Hoosier R80 Tires at High Toe for 48,000 Wheel Passes

\begin{tabular}{|c|c|c|c|c|c|c|c|}
\hline \multirow{2}{*}{ Mix Type } & \multirow{2}{*}{$\begin{array}{c}\text { Number of } \\
\text { Wheel } \\
\text { Passes } \\
\end{array}$} & \multirow{2}{*}{ Specimen } & \multicolumn{5}{|c|}{ British Pendulum Number (BPN) } \\
\hline & & & Trial 1 & Trial 2 & Trial 3 & Trial 4 & Average \\
\hline \multirow{5}{*}{$\begin{array}{c}\text { JFA 12.5mm Skid- } \\
\text { RAP I79 Field } \\
\text { Cores }\end{array}$} & 0 & D1 & 63 & 60 & 57 & 56 & 59.0 \\
\hline & 0 & D2 & 51 & 48 & 47 & 46 & 48.0 \\
\hline & 0 & D3 & 54 & 51 & 49 & 48 & 50.5 \\
\hline & 0 & D4 & 53 & 51 & 50 & 49 & 50.8 \\
\hline & 0 & D5 & 54 & 52 & 50 & 49 & 51.3 \\
\hline \multirow{7}{*}{ Dummy Samples } & 0 & T2 (JFA) & 77 & 77 & 78 & 77 & 77.3 \\
\hline & 0 & T5 (WVP W1) & 72 & 72 & 72 & 71 & 71.8 \\
\hline & 0 & T6 (WVP W1) & 86 & 85 & 87 & 86 & 86.0 \\
\hline & 0 & $\begin{array}{c}\text { T11 (WVP } \\
12.5)\end{array}$ & 77 & 78 & 78 & 77 & 77.5 \\
\hline & 0 & $\begin{array}{c}\text { T14 (WVP } \\
12.5)\end{array}$ & 82 & 84 & 85 & 84 & 83.8 \\
\hline & 0 & S8G (Greer) & 74 & 72 & 71 & 70 & 71.8 \\
\hline & 0 & S11G (Greer) & 74 & 73 & 73 & 72 & 73.0 \\
\hline & & & & & & & \\
\hline \multirow{5}{*}{$\begin{array}{c}\text { JFA 12.5mm Skid- } \\
\text { RAP I79 Field } \\
\text { Cores }\end{array}$} & 8000 & D1 & 52 & 50 & 48 & 48 & 49.5 \\
\hline & 8000 & D2 & 49 & 47 & 47 & 46 & 47.3 \\
\hline & 8000 & D3 & 50 & 47 & 47 & 47 & 47.8 \\
\hline & 8000 & D4 & 50 & 48 & 48 & 48 & 48.5 \\
\hline & 8000 & D5 & 50 & 49 & 48 & 48 & 48.8 \\
\hline \multirow{7}{*}{ Dummy Samples } & 8000 & T2 (JFA) & 51 & 49 & 48 & 48 & 49.0 \\
\hline & 8000 & T5 (WVP W1) & 57 & 55 & 54 & 54 & 55.0 \\
\hline & 8000 & T6 (WVP W1) & 58 & 52 & 51 & 51 & 53.0 \\
\hline & 8000 & $\begin{array}{c}\text { T11 (WVP } \\
12.5)\end{array}$ & 55 & 53 & 53 & 52 & 53.3 \\
\hline & 8000 & $\begin{array}{c}\text { T14 (WVP } \\
12.5)\end{array}$ & 55 & 53 & 52 & 52 & 53.0 \\
\hline & 8000 & S8G (Greer) & 51 & 50 & 49 & 49 & 49.8 \\
\hline & 8000 & S11G (Greer) & 48 & 47 & 47 & 47 & $\begin{array}{l}47.3 \\
\end{array}$ \\
\hline \multirow{4}{*}{$\begin{array}{c}\text { JFA 12.5mm Skid- } \\
\text { RAP I79 Field } \\
\text { Cores }\end{array}$} & 24000 & D1 & 48 & 46 & 46 & 45 & 46.3 \\
\hline & 24000 & D2 & 46 & 46 & 44 & 44 & 45 \\
\hline & 24000 & D3 & 45 & 43 & 42 & 42 & 43.0 \\
\hline & 24000 & D4 & 47 & 46 & 45 & 44 & 45.5 \\
\hline
\end{tabular}




\begin{tabular}{|c|c|c|c|c|c|c|c|}
\hline \multirow{3}{*}{ Mix Type } & \multirow{2}{*}{$\begin{array}{c}\text { Number of } \\
\text { Wheel } \\
\text { Passes } \\
\end{array}$} & \multirow{2}{*}{ Specimen } & \multicolumn{5}{|c|}{ British Pendulum Number (BPN) } \\
\hline & & & Trial 1 & Trial 2 & Trial 3 & Trial 4 & Average \\
\hline & 24000 & D5 & 47 & 45 & 45 & 44 & 45.3 \\
\hline \multirow{7}{*}{ Dummy Samples } & 24000 & T2 (JFA) & 47 & 46 & 46 & 45 & 46.0 \\
\hline & 24000 & T5 (WVP W1) & 50 & 48 & 48 & 47 & 48.3 \\
\hline & 24000 & T6 (WVP W1) & 51 & 49 & 48 & 48 & 49.0 \\
\hline & 24000 & $\begin{array}{c}\text { T11 (WVP } \\
12.5)\end{array}$ & 52 & 50 & 49 & 48 & 49.8 \\
\hline & 24000 & $\begin{array}{c}\text { T14 (WVP } \\
12.5)\end{array}$ & 53 & 52 & 51 & 51 & 51.8 \\
\hline & 24000 & S8G (Greer) & 48 & 46 & 46 & 46 & 46.5 \\
\hline & 24000 & S11G (Greer) & 47 & 46 & 46 & 45 & 46.0 \\
\hline & & & & & & & \\
\hline \multirow{5}{*}{$\begin{array}{c}\text { JFA 12.5mm Skid- } \\
\text { RAP I79 Field } \\
\text { Cores }\end{array}$} & 48000 & D1 & 43 & 43 & 41 & 41 & 42 \\
\hline & 48000 & D2 & 43 & 42 & 42 & 41 & 42 \\
\hline & 48000 & D3 & 42 & 40 & 39 & 39 & 40 \\
\hline & 48000 & D4 & 42 & 40 & 40 & 39 & 40.3 \\
\hline & 48000 & D5 & 42 & 41 & 40 & 39 & 40.5 \\
\hline \multirow{7}{*}{ Dummy Samples } & 48000 & T2 (JFA) & 41 & 40 & 39 & 38 & 39.5 \\
\hline & 48000 & T5 (WVP W1) & 47 & 46 & 45 & 44 & 45.5 \\
\hline & 48000 & T6 (WVP W1) & 45 & 43 & 43 & 42 & 43.3 \\
\hline & 48000 & $\begin{array}{c}\text { T11 (WVP } \\
12.5)\end{array}$ & 47 & 45 & 44 & 44 & 45.0 \\
\hline & 48000 & $\begin{array}{c}\text { T14 (WVP } \\
12.5) \\
\end{array}$ & 46 & 45 & 44 & 44 & 44.8 \\
\hline & 48000 & S8G (Greer) & 42 & 41 & 41 & 41 & 41.3 \\
\hline & 48000 & S11G (Greer) & 41 & 40 & 39 & 38 & 39.5 \\
\hline
\end{tabular}

\section{Trial 10: JFA 12.5mm SR I-79 Field Measurements}

Table 54: BPN Measurements for Trial 9 JFA 12.5mm SR I-79 Field Locations

\begin{tabular}{|c|c|c|c|c|c|c|c|c|c|}
\hline \multirow{2}{*}{$\begin{array}{l}\text { Location } \\
\text { /Core } \\
\text { Number } \\
\end{array}$} & \multirow[b]{2}{*}{$\begin{array}{c}\text { Downhill/Up } \\
\text { hill }\end{array}$} & \multirow[b]{2}{*}{$\begin{array}{c}\text { Location } \\
\text { on Lane }\end{array}$} & \multicolumn{7}{|c|}{ British Pendulum Number (BPN) } \\
\hline & & & $\begin{array}{c}\text { Trial } \\
1\end{array}$ & $\begin{array}{c}\text { Trial } \\
2\end{array}$ & $\begin{array}{c}\text { Trial } \\
\mathbf{3}\end{array}$ & $\begin{array}{c}\text { Trial } \\
4\end{array}$ & Avg. & $\begin{array}{l}\text { Lane } \\
\text { Avg. }\end{array}$ & $\begin{array}{c}\text { Uphill/ } \\
\text { Downhill } \\
\text { Avg. }\end{array}$ \\
\hline \multirow[t]{2}{*}{ D1 } & \multirow[t]{2}{*}{ Flat Curve } & $\begin{array}{l}\text { Right } \\
\text { Wheel } \\
\text { Path }\end{array}$ & 76 & 72 & 73 & 72 & 73.25 & 74.5 & \multirow[t]{2}{*}{74.5} \\
\hline & & Center & 75 & 76 & 76 & 76 & 75.75 & & \\
\hline D2 & Uphill & $\begin{array}{c}\text { Left } \\
\text { Wheel } \\
\text { Path } \\
\end{array}$ & 86 & 84 & 82 & 80 & 83 & 84.5 & 69.9 \\
\hline
\end{tabular}




\begin{tabular}{|c|c|c|c|c|c|c|c|c|c|}
\hline \multirow[b]{2}{*}{$\begin{array}{l}\text { Location } \\
\text { /Core } \\
\text { Number } \\
\end{array}$} & \multirow[b]{2}{*}{$\begin{array}{c}\text { Downhill/Up } \\
\text { hill }\end{array}$} & \multirow[b]{2}{*}{$\begin{array}{c}\text { Location } \\
\text { on Lane }\end{array}$} & \multicolumn{7}{|c|}{ British Pendulum Number (BPN) } \\
\hline & & & $\begin{array}{c}\text { Trial } \\
1\end{array}$ & $\begin{array}{c}\text { Trial } \\
2\end{array}$ & $\begin{array}{c}\text { Trial } \\
\mathbf{3}\end{array}$ & $\begin{array}{c}\text { Trial } \\
4\end{array}$ & Avg. & $\begin{array}{l}\text { Lane } \\
\text { Avg. }\end{array}$ & $\begin{array}{c}\text { Uphill/ } \\
\text { Downhill } \\
\text { Avg. }\end{array}$ \\
\hline & & Center & 86 & 86 & 86 & 86 & 86 & & \\
\hline & Downhill & $\begin{array}{c}\text { Left } \\
\text { Wheel } \\
\text { Path }\end{array}$ & 56 & 55 & 54 & 54 & 54.75 & 55.4 & \\
\hline & & Center & 56 & 55 & 56 & 57 & 56 & & \\
\hline \multirow{4}{*}{ D3 } & \multirow[t]{2}{*}{ Uphill } & $\begin{array}{c}\text { Left } \\
\text { Wheel } \\
\text { Path } \\
\end{array}$ & 77 & 75 & 74 & 74 & 75 & 74.1 & \multirow{4}{*}{67.4} \\
\hline & & Center & 74 & 74 & 73 & 72 & 73.25 & & \\
\hline & \multirow[t]{2}{*}{ Downhill } & $\begin{array}{c}\text { Left } \\
\text { Wheel } \\
\text { Path }\end{array}$ & 61 & 62 & 61 & 60 & 61 & 60.6 & \\
\hline & & Center & 61 & 60 & 60 & 60 & 60.25 & & \\
\hline \multirow{4}{*}{ D4 } & \multirow[t]{2}{*}{ Downhill } & $\begin{array}{c}\text { Right } \\
\text { Wheel } \\
\text { Path } \\
\end{array}$ & 55 & 55 & 54 & 53 & 54.25 & 55.5 & \multirow{4}{*}{73.5} \\
\hline & & Center & 57 & 57 & 57 & 56 & 56.75 & & \\
\hline & \multirow[t]{2}{*}{ Uphill } & $\begin{array}{c}\text { Right } \\
\text { Wheel } \\
\text { Path }\end{array}$ & 93 & 92 & 91 & 92 & 92 & 91.5 & \\
\hline & & Center & 92 & 92 & 90 & 90 & 91 & & \\
\hline \multirow{4}{*}{ D5 } & \multirow[t]{2}{*}{ Downhill } & $\begin{array}{l}\text { Right } \\
\text { Wheel } \\
\text { Path }\end{array}$ & 77 & 76 & 75 & 74 & 75.5 & 76.3 & \multirow{4}{*}{86.3} \\
\hline & & Center & 77 & 77 & 77 & 77 & 77 & & \\
\hline & \multirow[t]{2}{*}{ Uphill } & $\begin{array}{l}\text { Right } \\
\text { Wheel } \\
\text { Path }\end{array}$ & 96 & 95 & 95 & 94 & 95 & 96.4 & \\
\hline & & Center & 97 & 99 & 98 & 97 & 97.75 & & \\
\hline
\end{tabular}




\section{Appendix E: BPN Analysis}

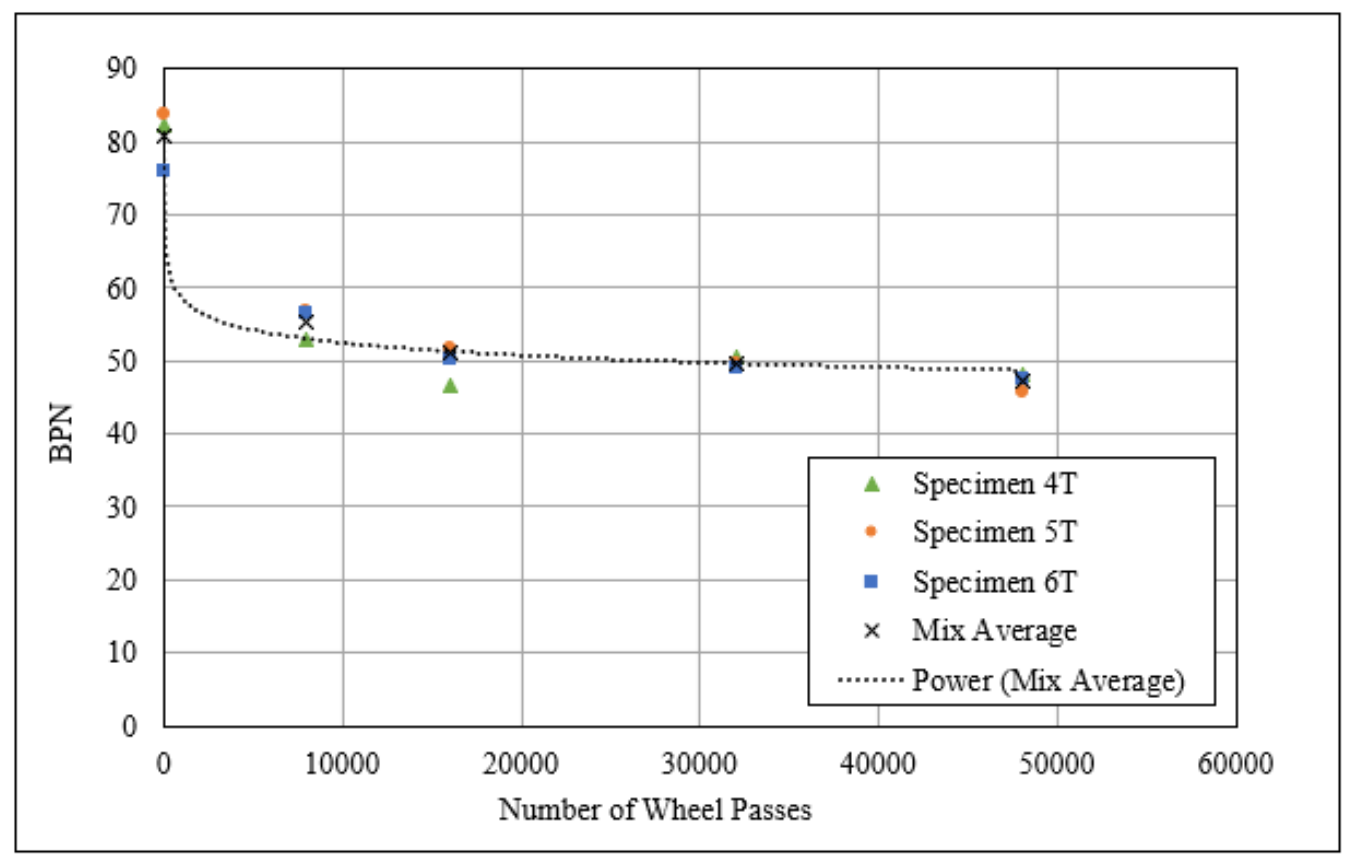

Figure 31: Trial 2 Average BPN Trend for JFA 12.5mm SR Specimens (Top Surfaces) at 4\% VTM After 48,000 Wheel Passes

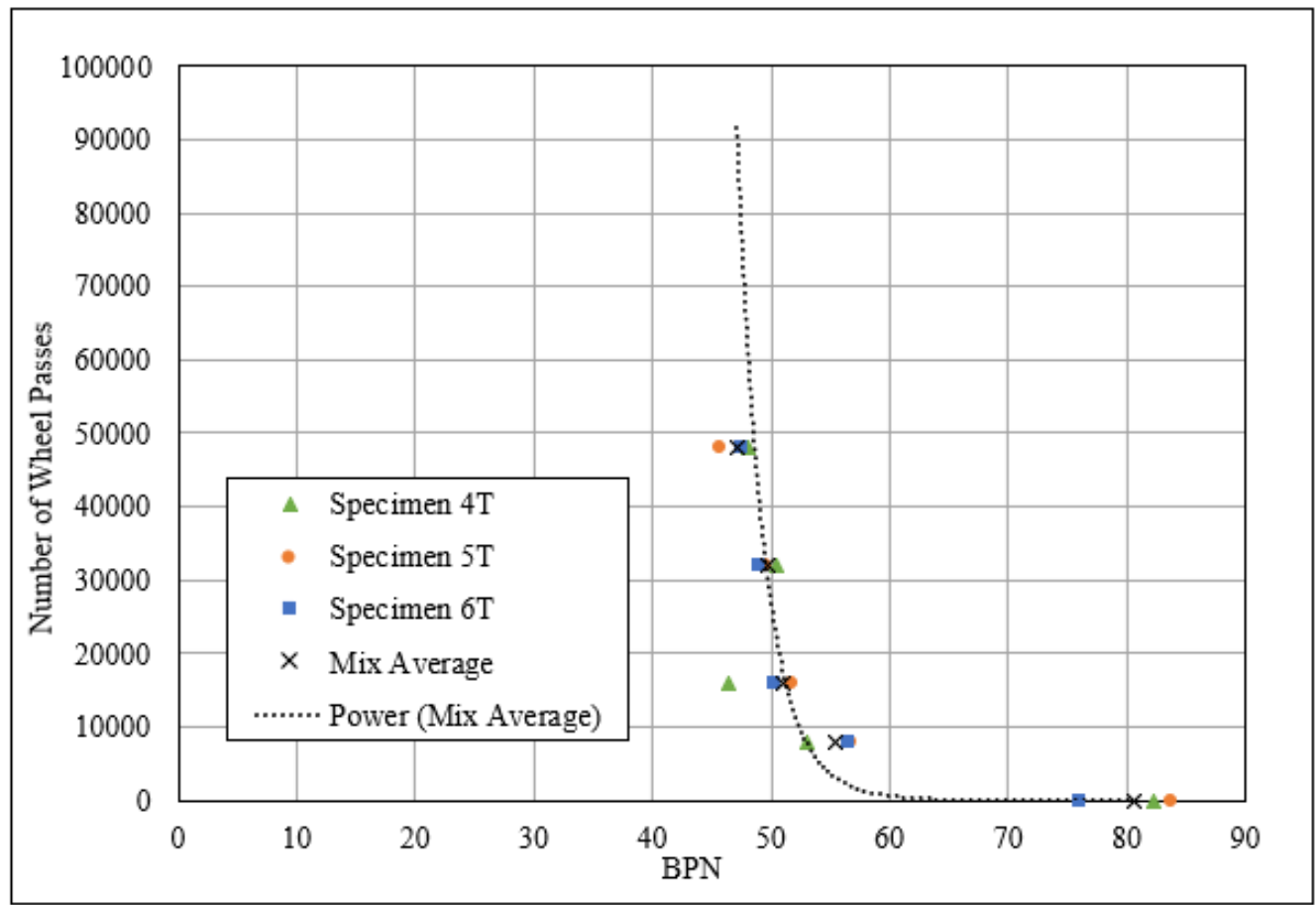

Figure 32: Trial 2 Prediction of Required Wheel Passes at BPN Limits for JFA 12.5mm SR Specimens (Top Surfaces) at 4\% VTM After 48,000 Wheel Passes 


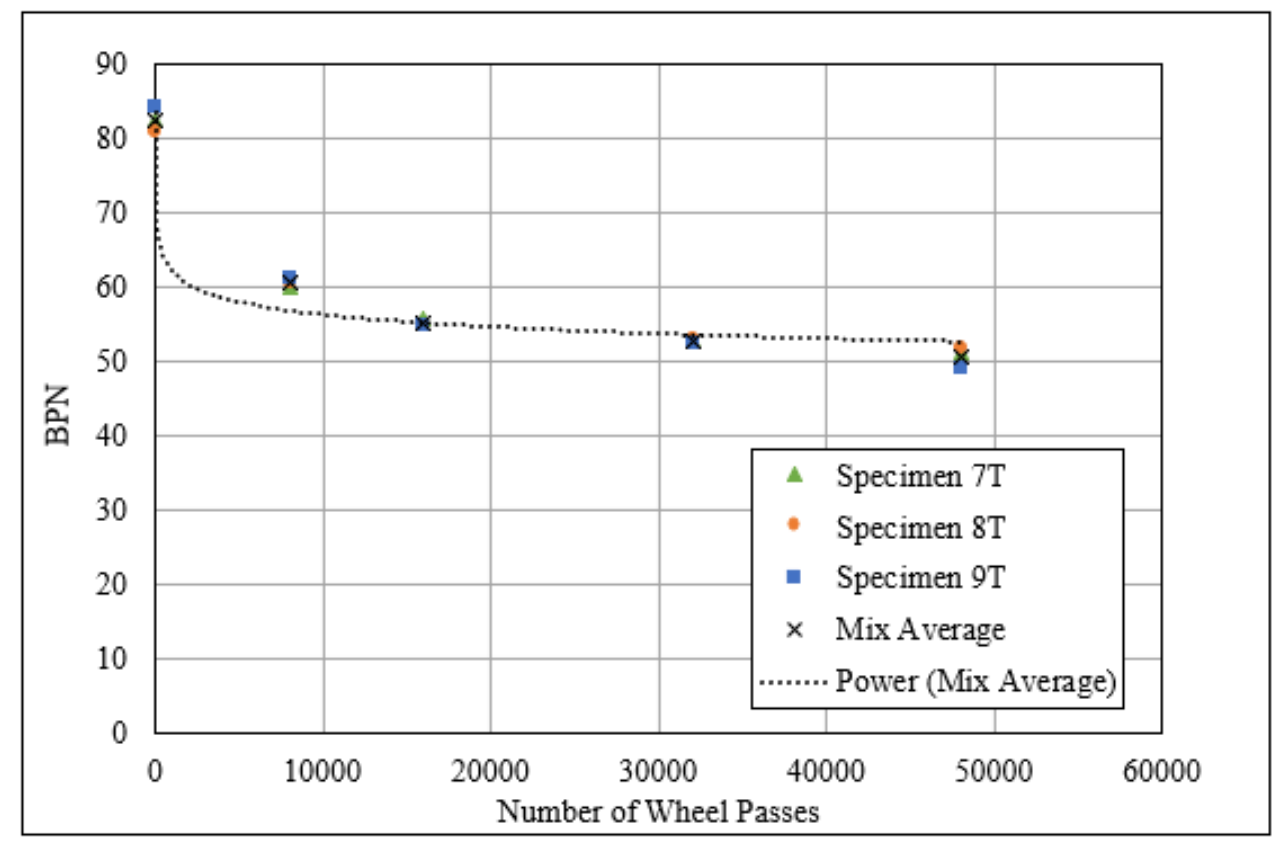

Figure 33: Trial 2 Average BPN Trend for WVP W1-RAP Specimens (Top Surfaces) at 4\% VTM After 48,000 Wheel Passes

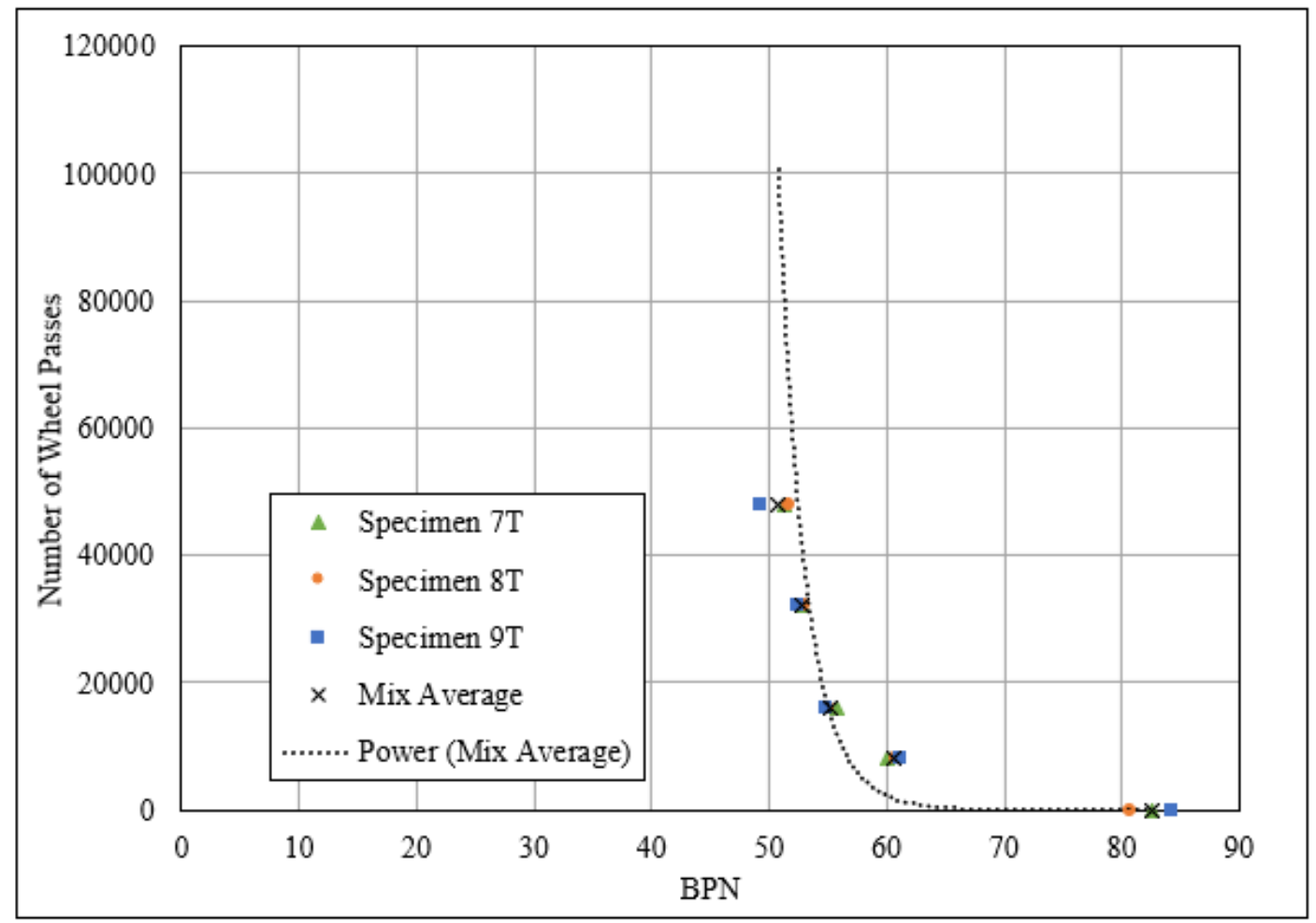

Figure 34: Trial 2 Prediction of Required Wheel Passes at BPN Limits for WVP W1-RAP Specimens (Top Surfaces) at 4\% VTM After 48,000 Wheel Passes 


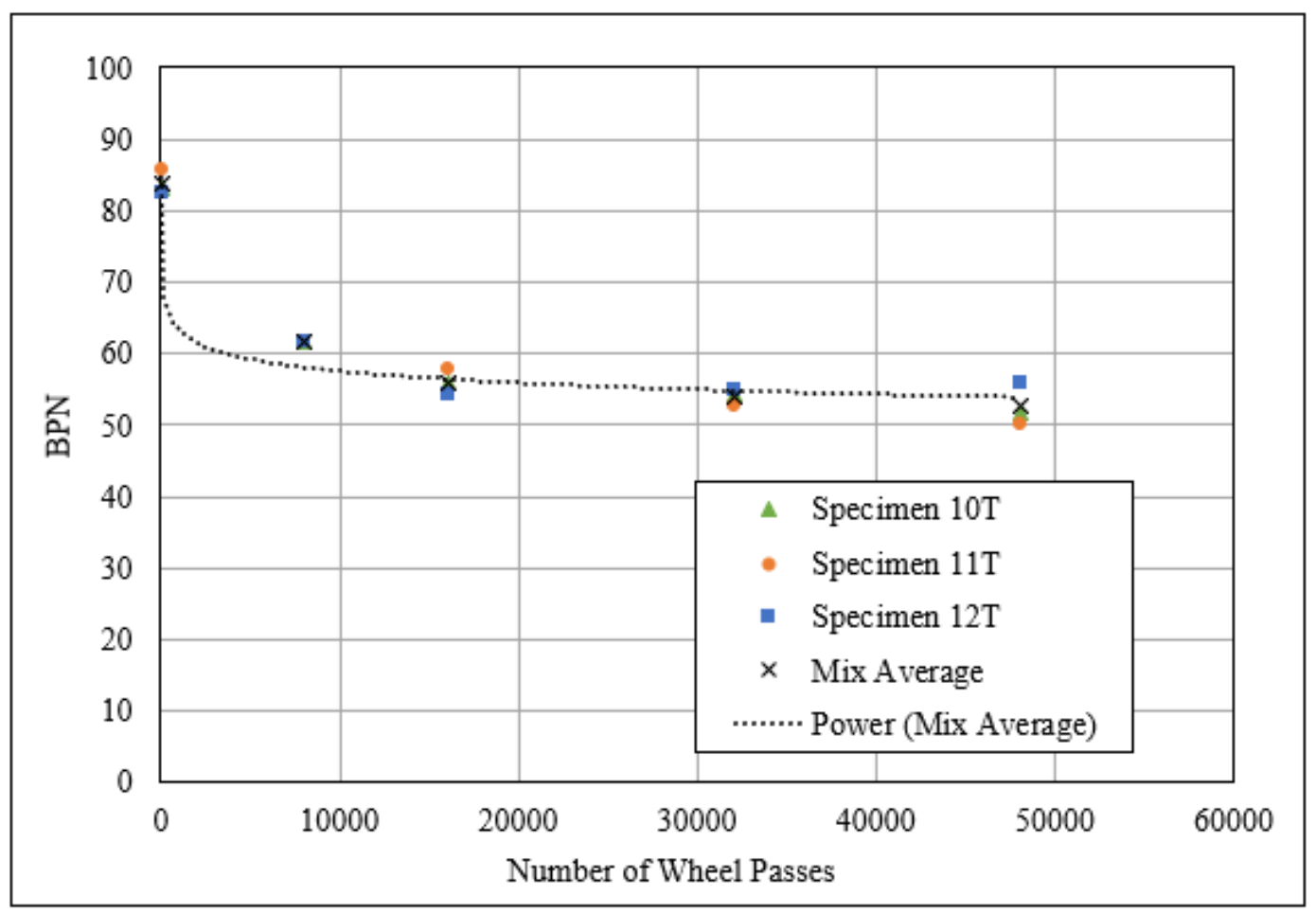

Figure 35: Trial 2 Average BPN Trend for WVP W1-RAP Specimens (Top Surfaces) at 8\% VTM After 48,000 Wheel Passes

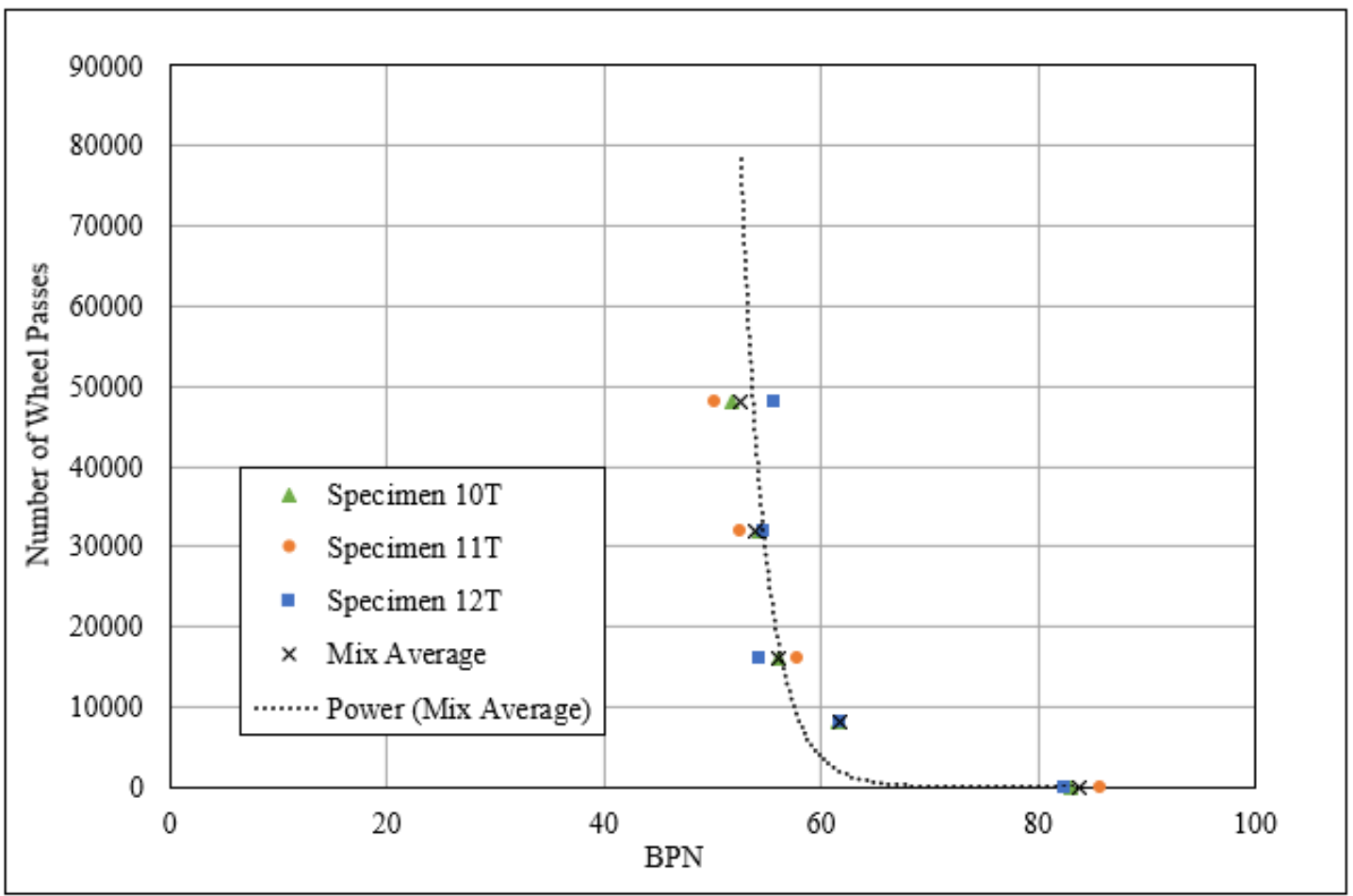

Figure 36: Trial 2 Prediction of Required Wheel Passes at BPN Limits for WVP W1-RAP Specimens (Top Surfaces) at 8\% VTM After 48,000 Wheel Passes 


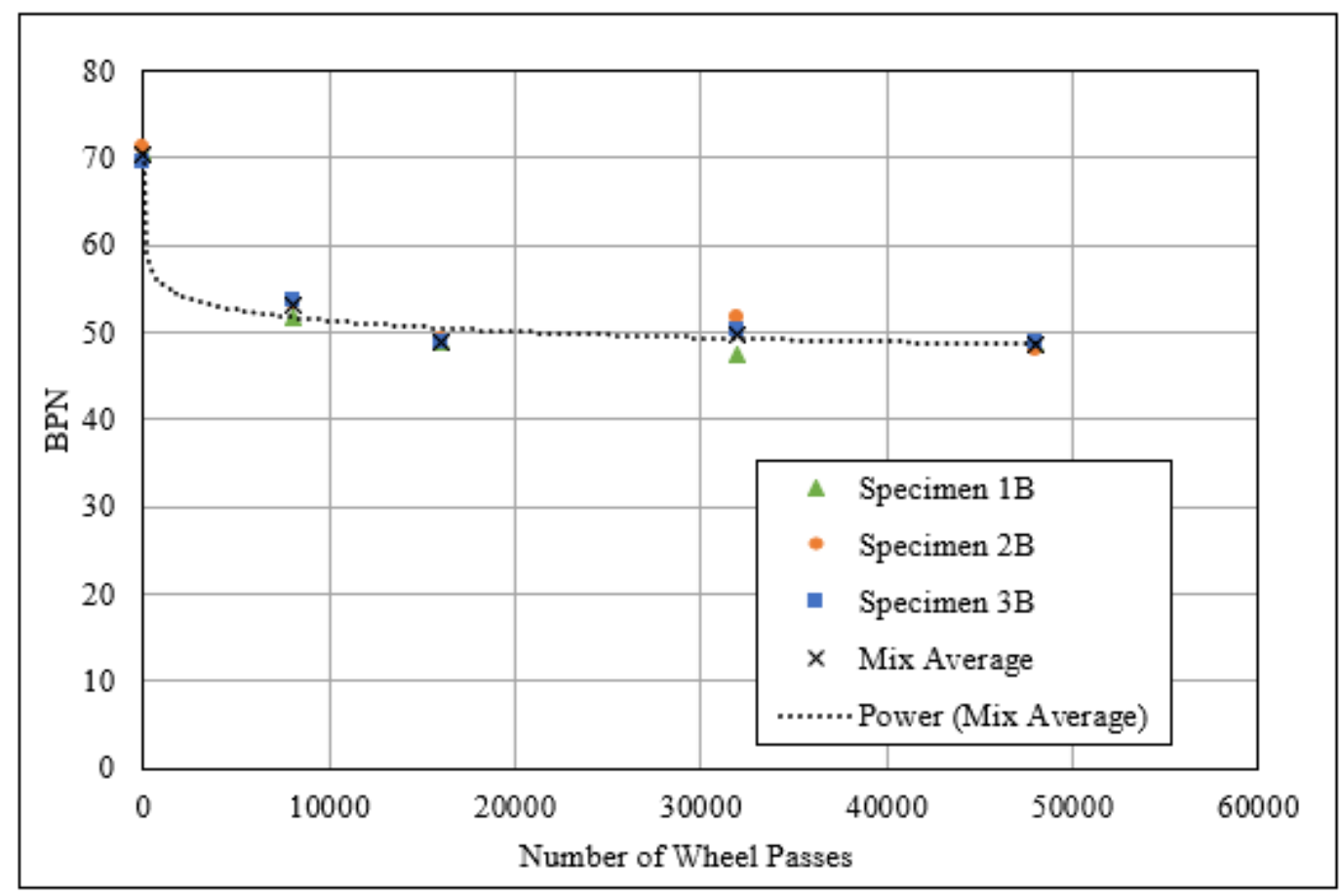

Figure 37: Trial 3 Average BPN Trend for JFA 12.5mm SR Specimens (Bottom Surfaces) at 8\% VTM After 48,000 Wheel Passes

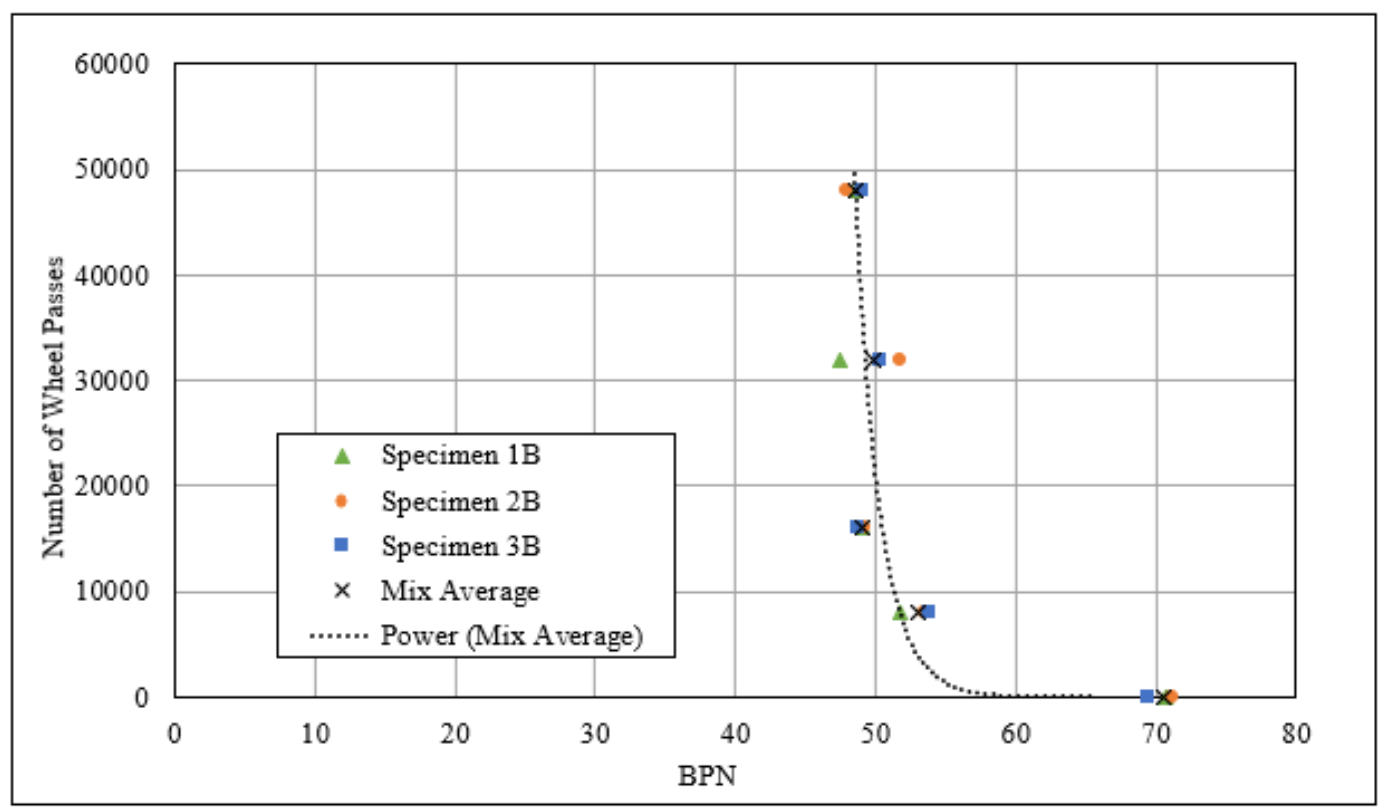

Figure 38: Trial 3 Prediction of Required Wheel Passes at BPN Limits for JFA 12.5mm SR Specimens (Bottom Surfaces) at 8\% VTM After 48,000 Wheel Passes 


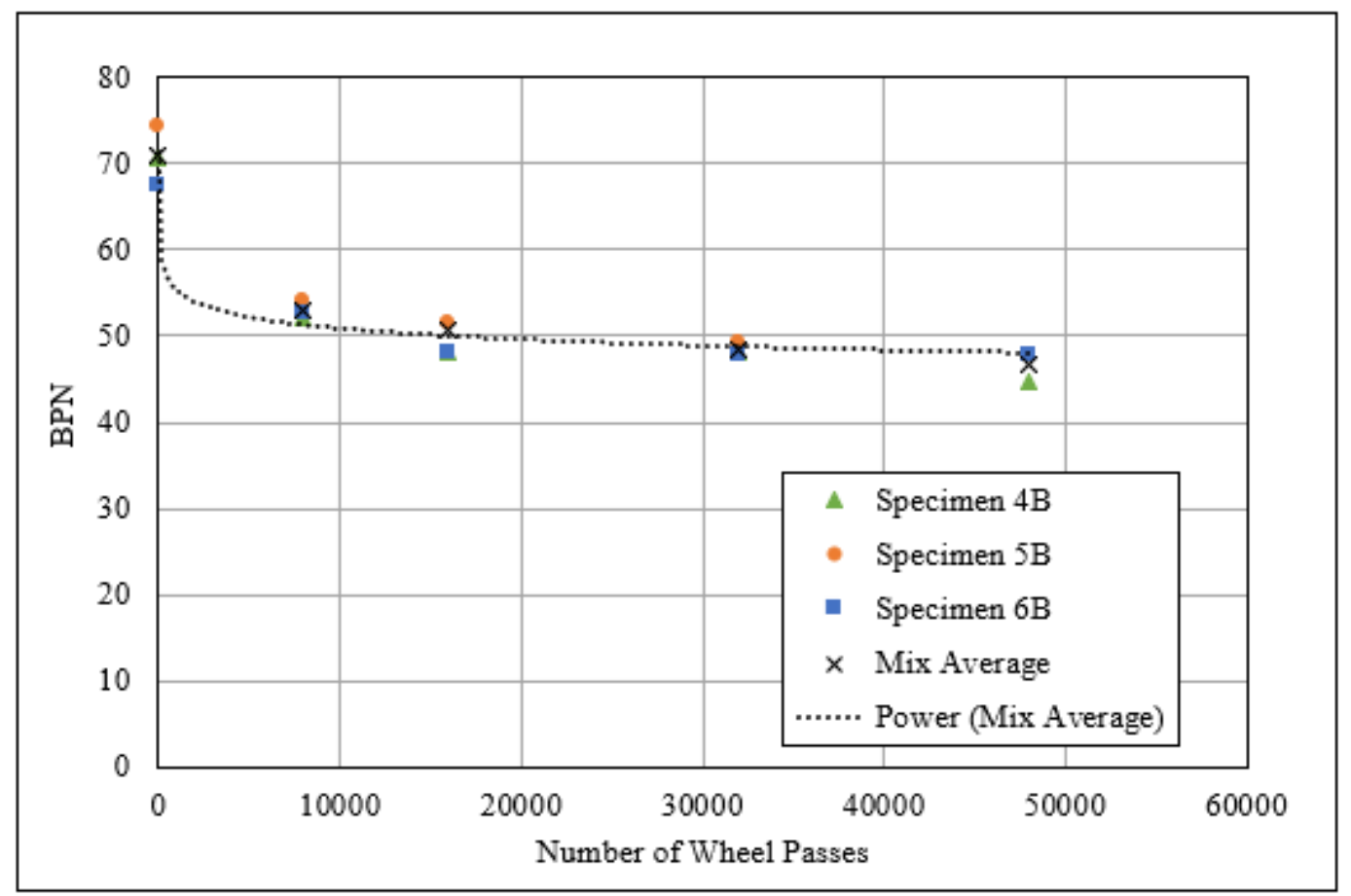

Figure 39: Trial 3 Average BPN Trend for JFA 12.5mm SR Specimens (Bottom Surfaces) at 4\% VTM After 48,000 Wheel Passes

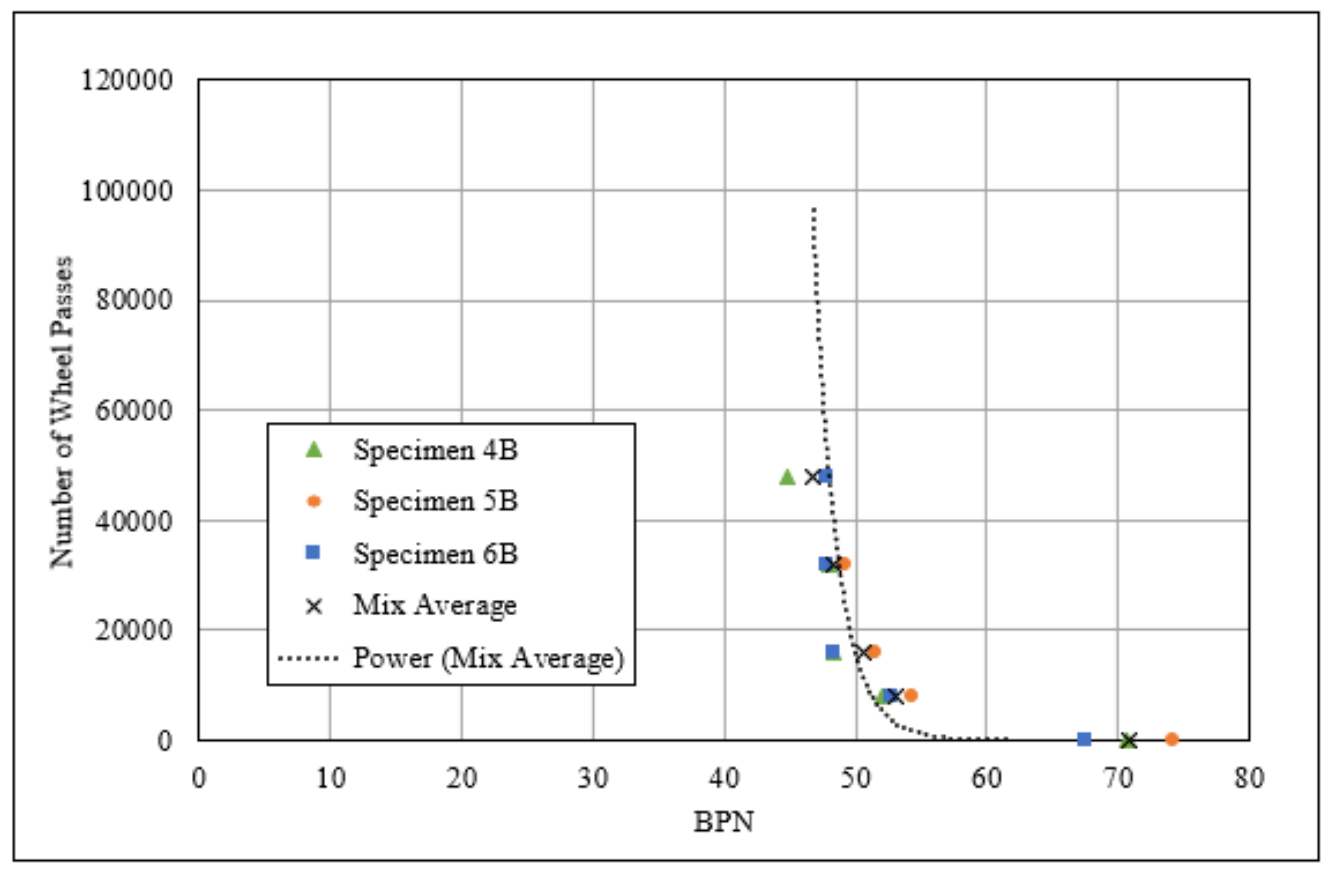

Figure 40: Trial 3 Prediction of Required Wheel Passes at BPN Limits for JFA 12.5mm SR Specimens (Bottom Surfaces) at 4\% VTM After 48,000 Wheel Passes 


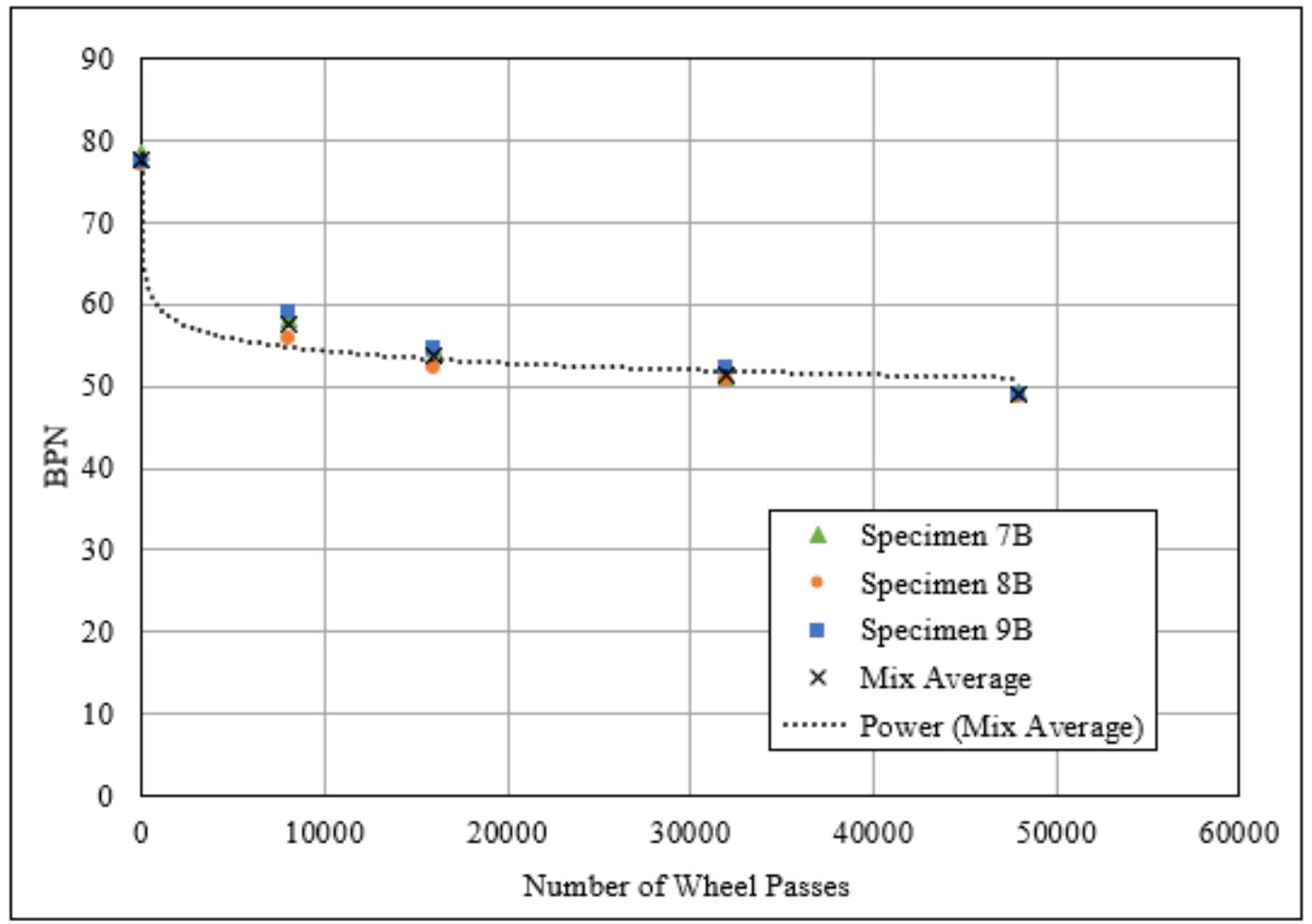

Figure 41: Trial 3 Average BPN Trend for WVP W1-RAP Specimens (Bottom Surfaces) at 4\% VTM After 48,000 Wheel Passes

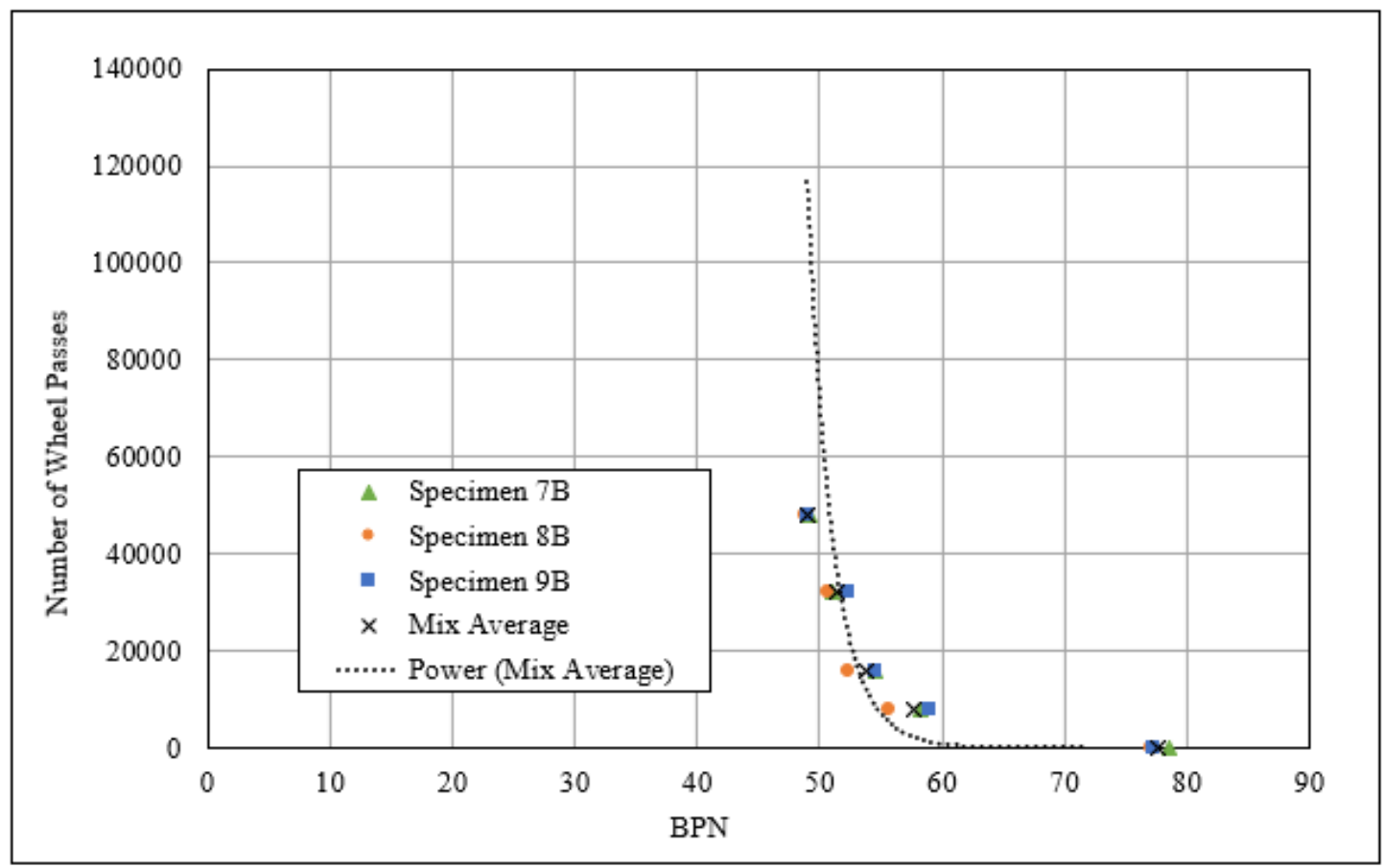

Figure 42: Trial 3 Prediction of Required Wheel Passes at BPN Limits for WVP W1-RAP Specimens (Bottom Surfaces) at 4\% VTM After 48,000 Wheel Passes 


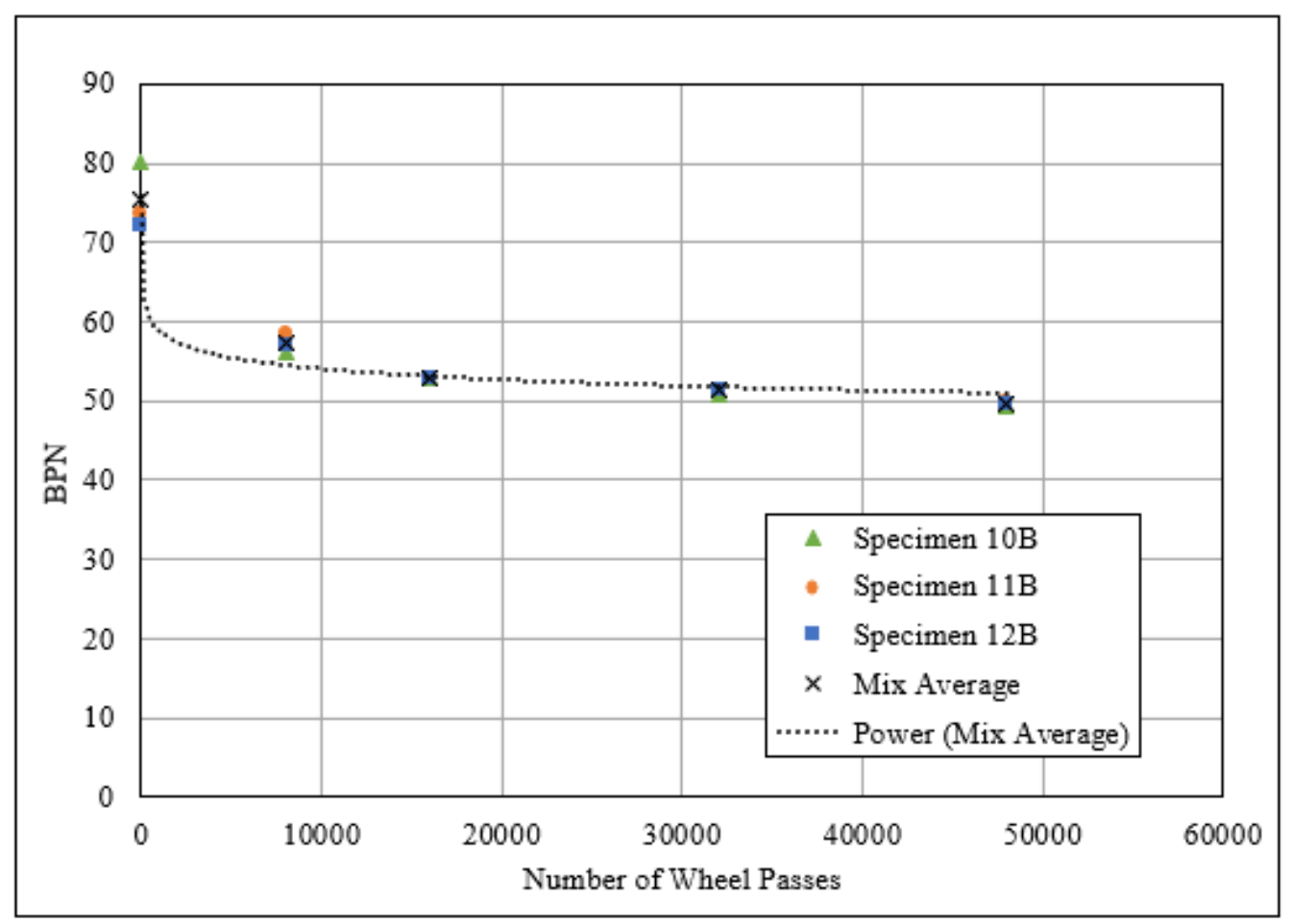

Figure 43: Trial 3 Average BPN Trend for WVP WI-RAP Specimens (Bottom Surfaces) at 8\% VTM After 48,000 Wheel Passes

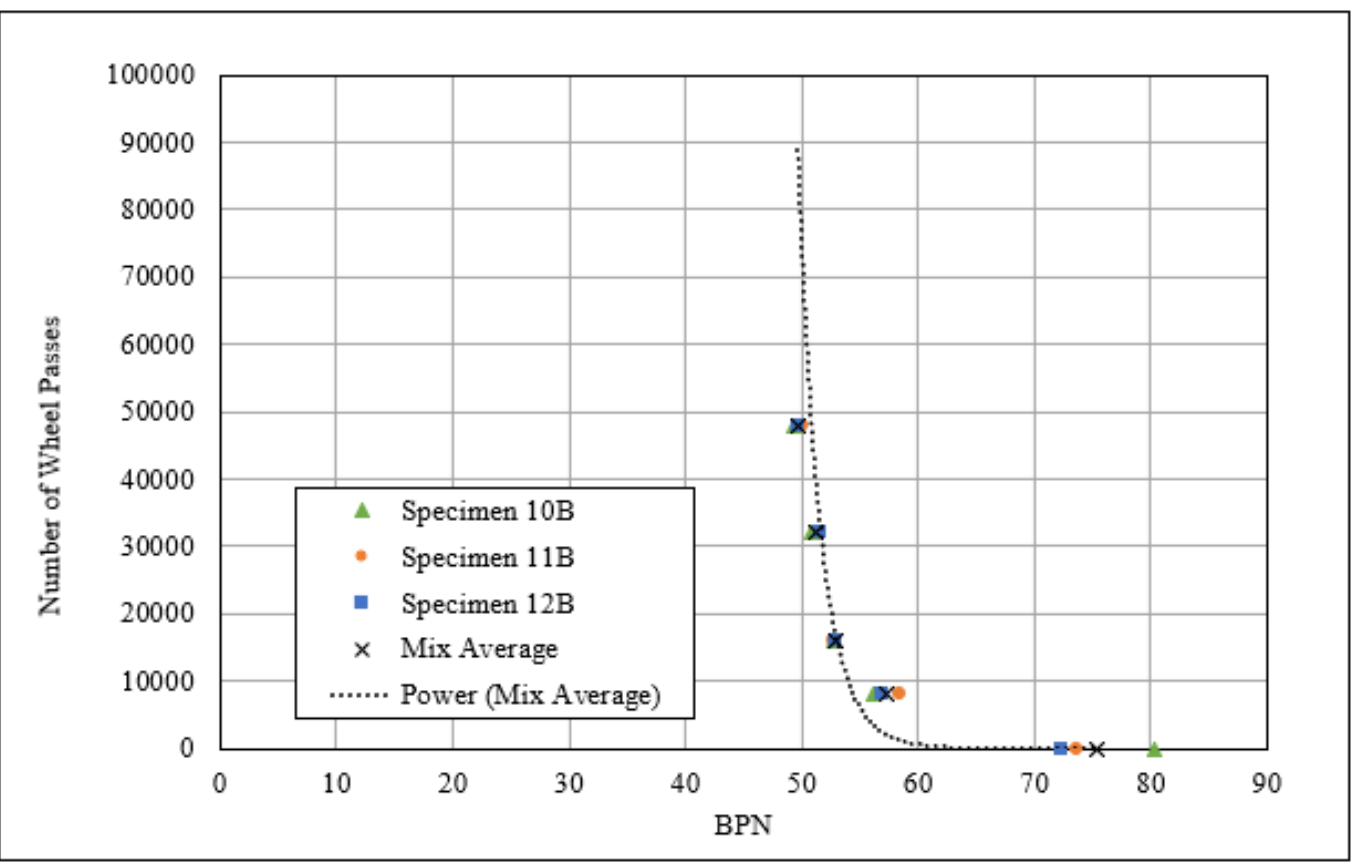

Figure 44: Trial 3 Prediction of Required Wheel Passes at BPN Limits for WVP W1-RAP Specimens (Bottom Surfaces) at 8\% VTM After 48,000 Wheel Passes 


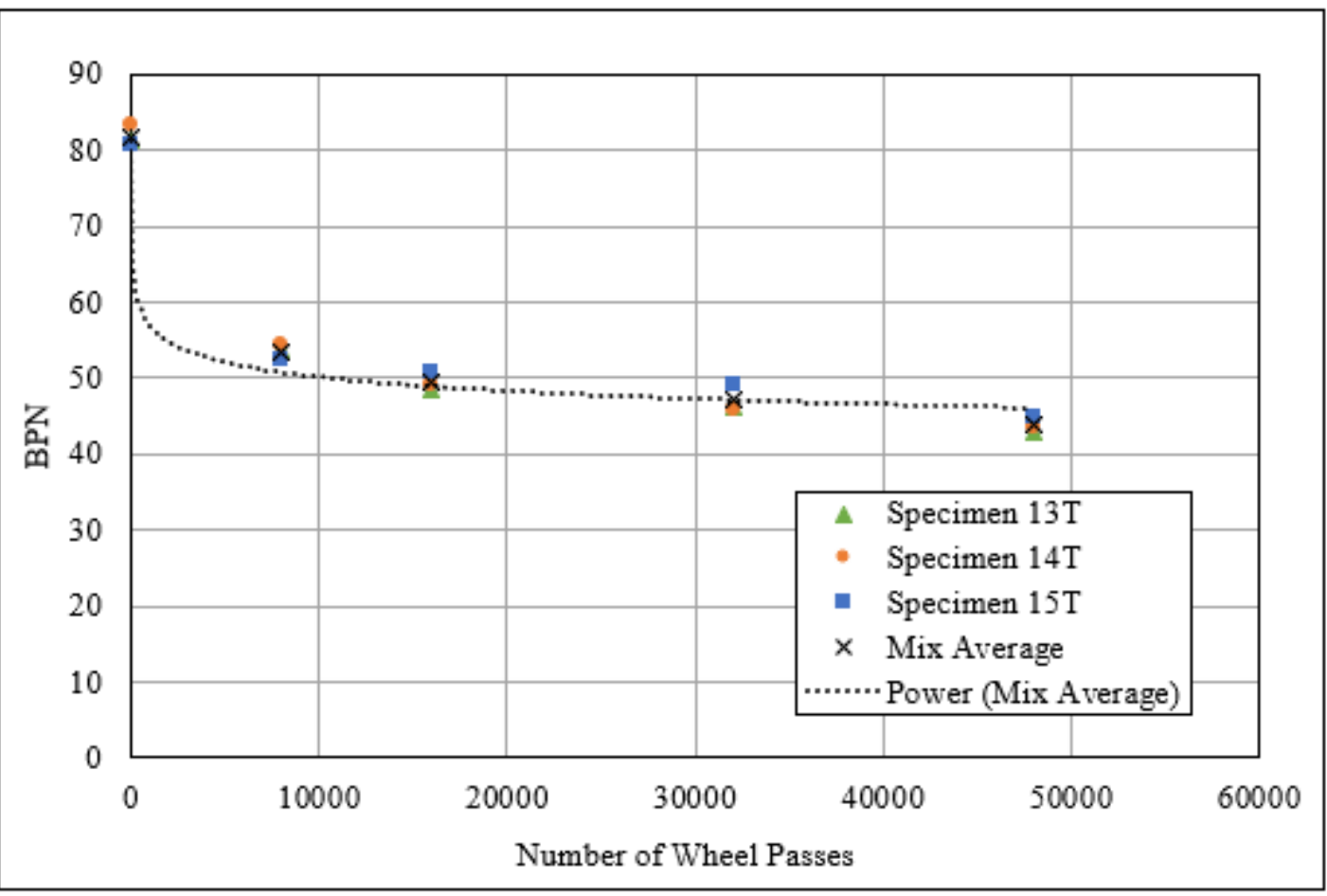

Figure 45: Trial 4 Average BPN Trend for Greer W1H Specimens (Top Surfaces) at 8\% VTM After 48,000 Wheel Passes

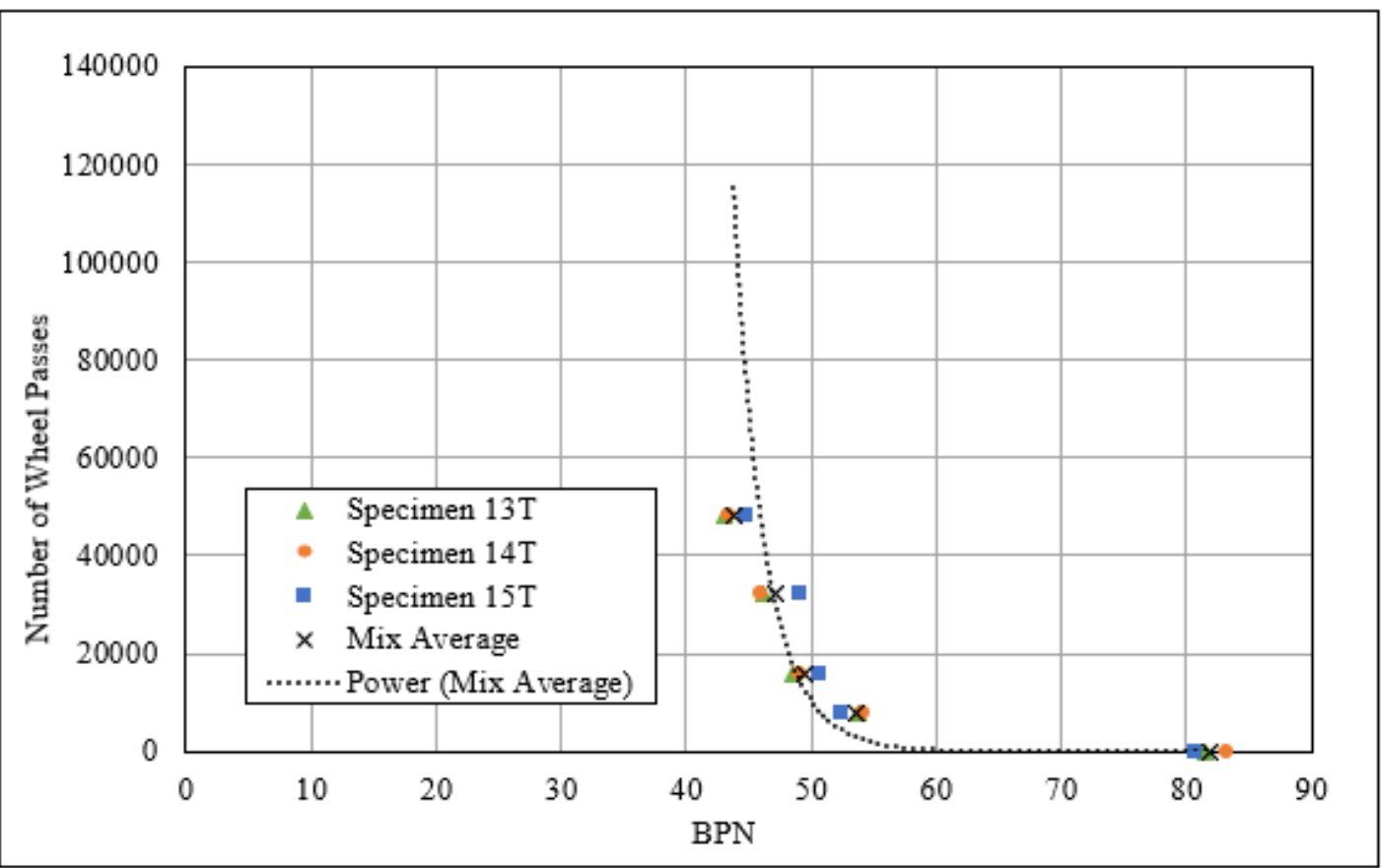

Figure 46: Trial 4 Prediction of Required Wheel Passes at BPN Limits for Greer W1H Specimens (Top Surfaces) at 8\% VTM After 48,000 Wheel Passes 


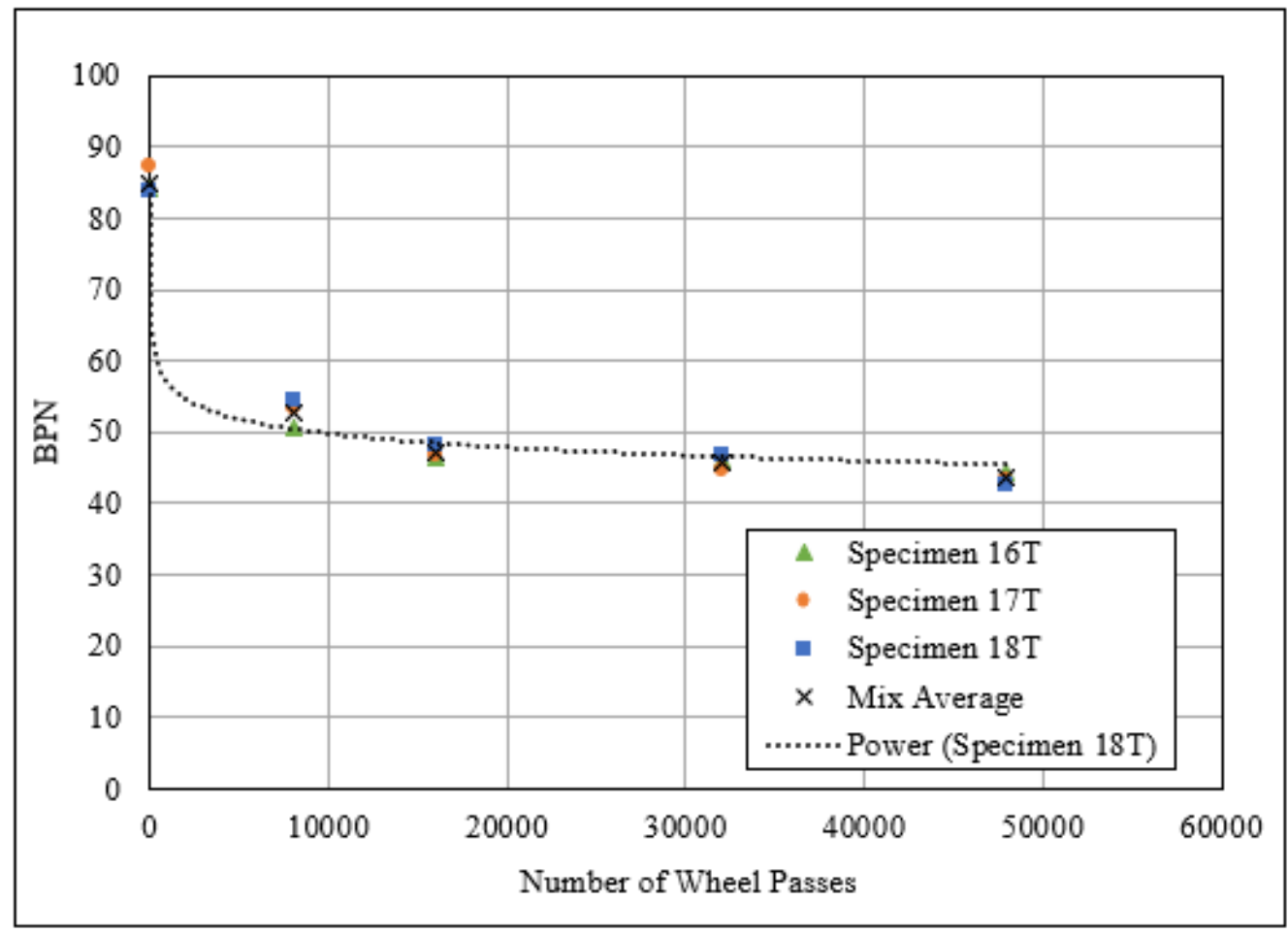

Figure 47: Trial 4 Average BPN Trend for Greer W1H Specimens (Top Surfaces) at 4\% VTM After 48,000 Wheel Passes

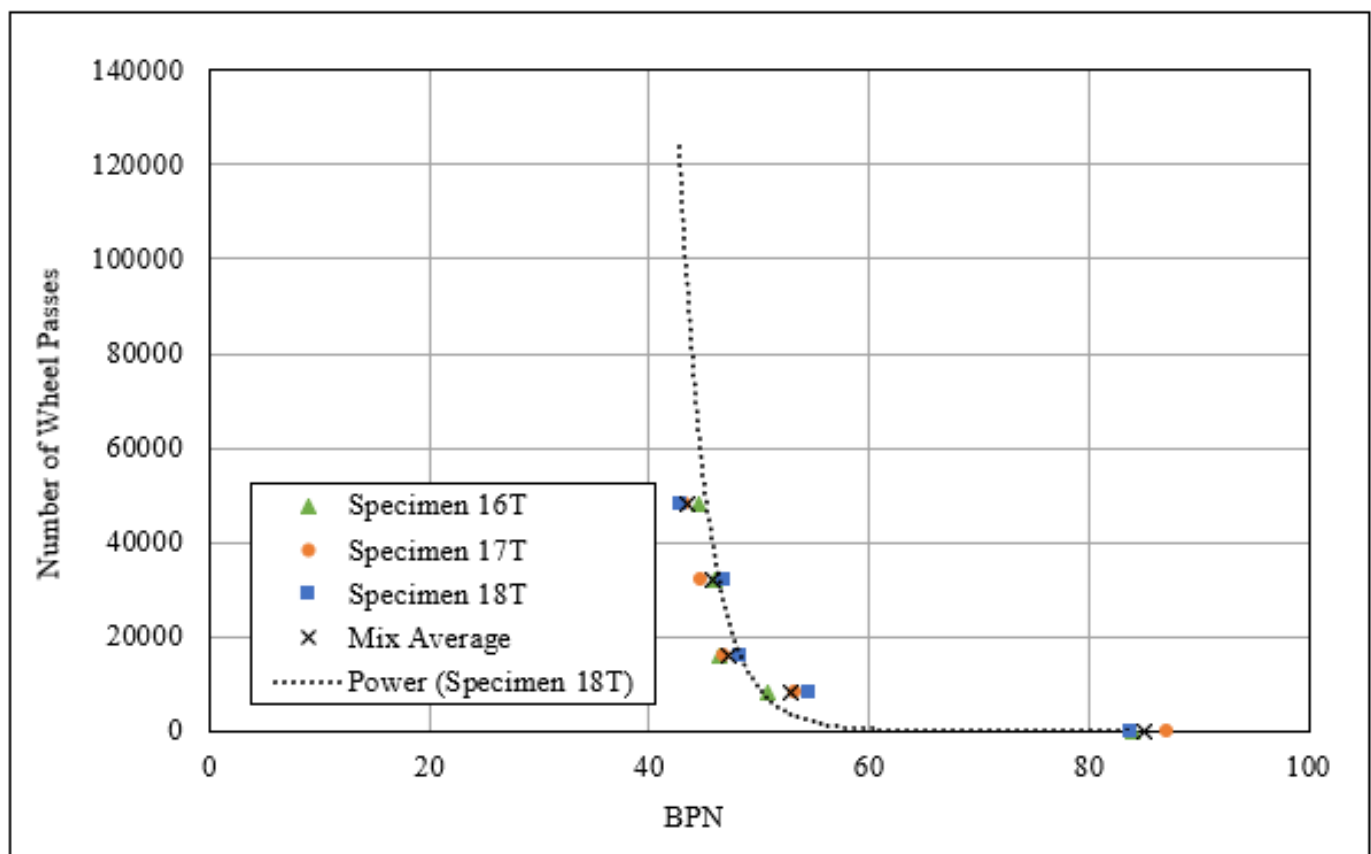

Figure 48: Trial 4 Prediction of Required Wheel Passes at BPN Limits for Greer W1H Specimens (Top Surfaces) at 4\% VTM After 48,000 Wheel Passes 


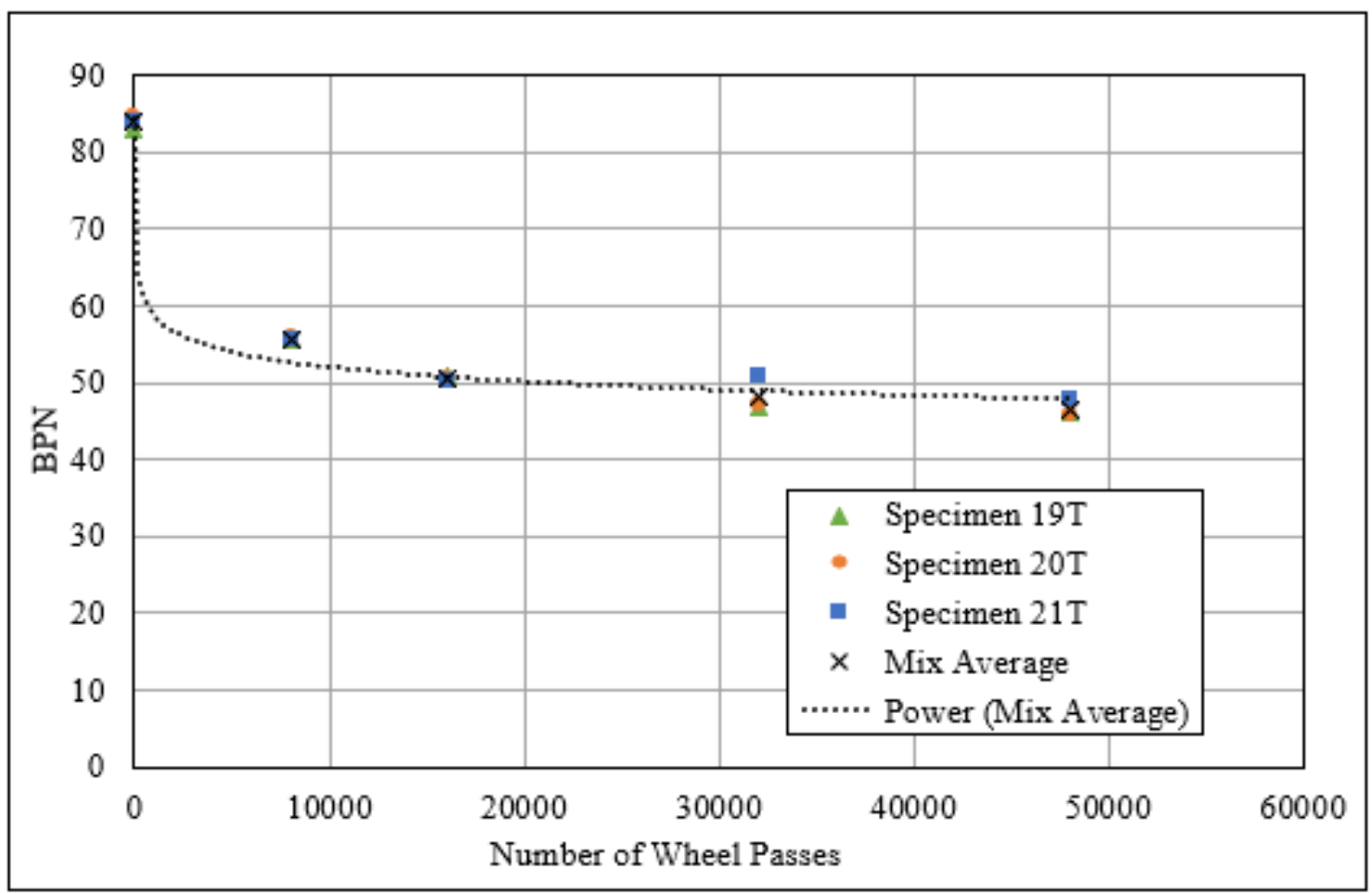

Figure 49: Trial 4 Average BPN Trend for WVP 12.5mm SR Specimens (Top Surfaces) at 4\% VTM After 48,000 Wheel Passes

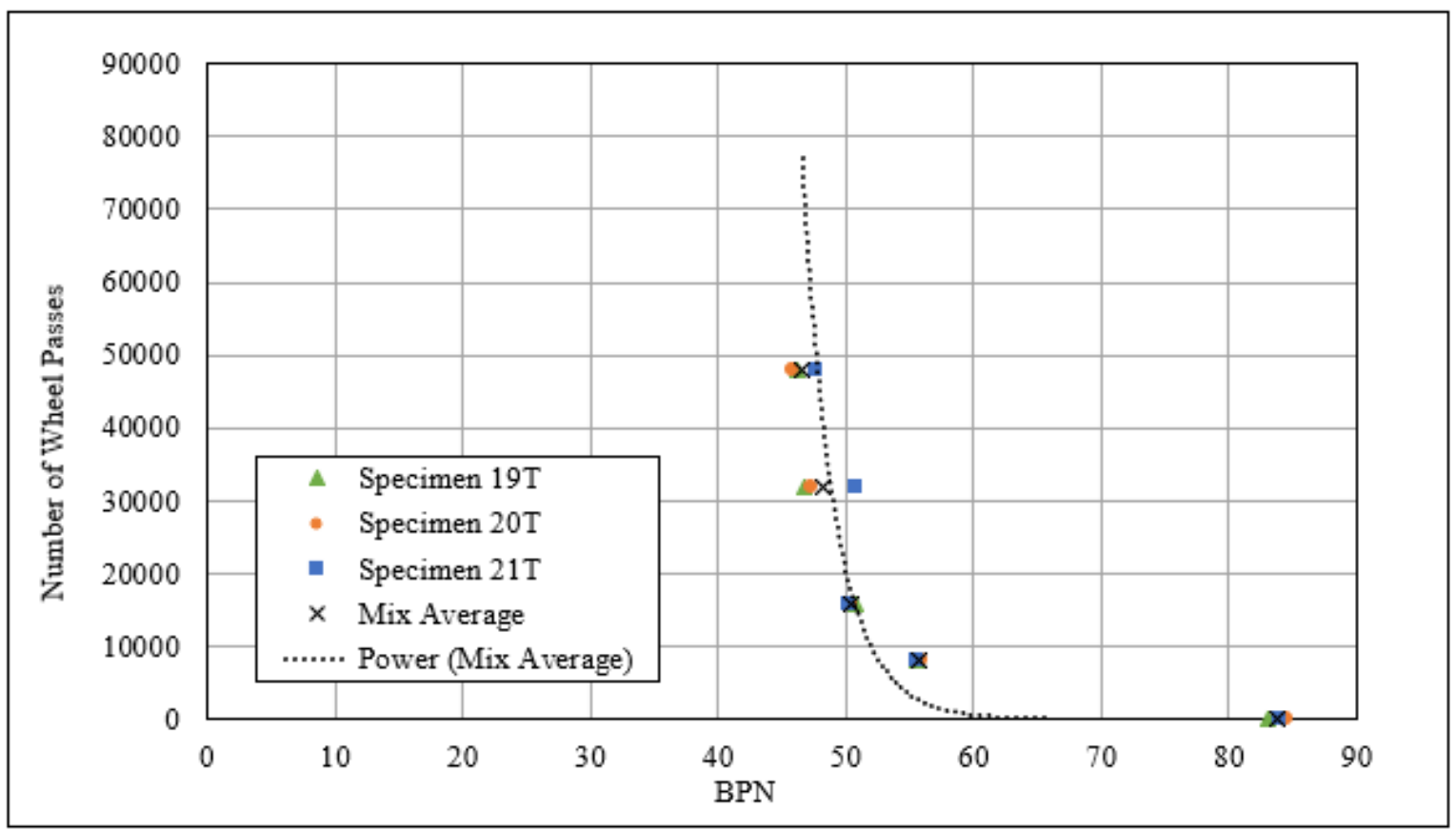

Figure 50: Trial 4 Prediction of Required Wheel Passes at BPN Limits for WVP 12.5mm SR Specimens (Top Surfaces) at 4\% VTM After 48,000 Wheel Passes 


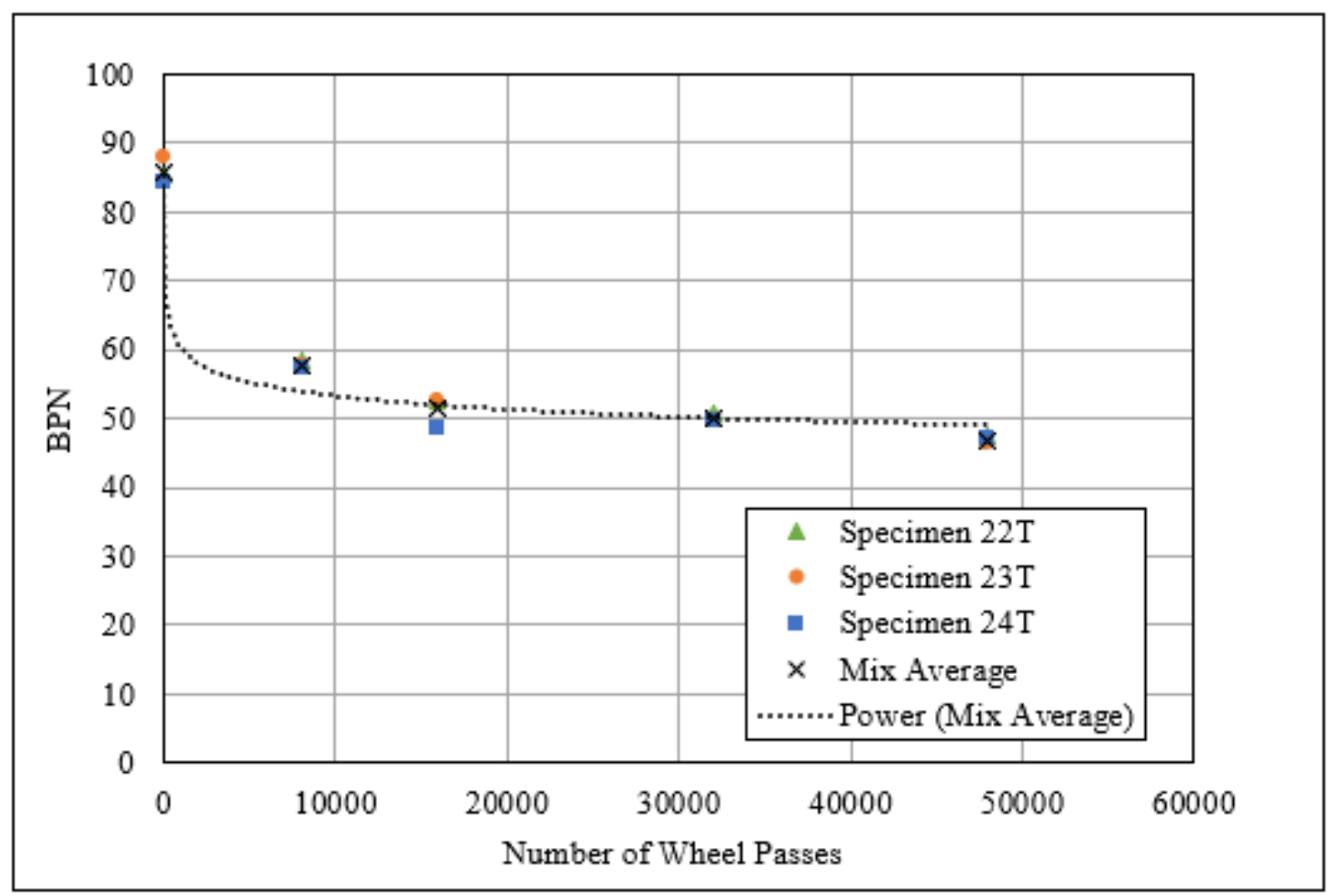

Figure 51: Trial 4 Average BPN Trend for WVP 12.5mm SR Specimens (Top Surfaces) at 8\% VTM After 48,000 Wheel Passes

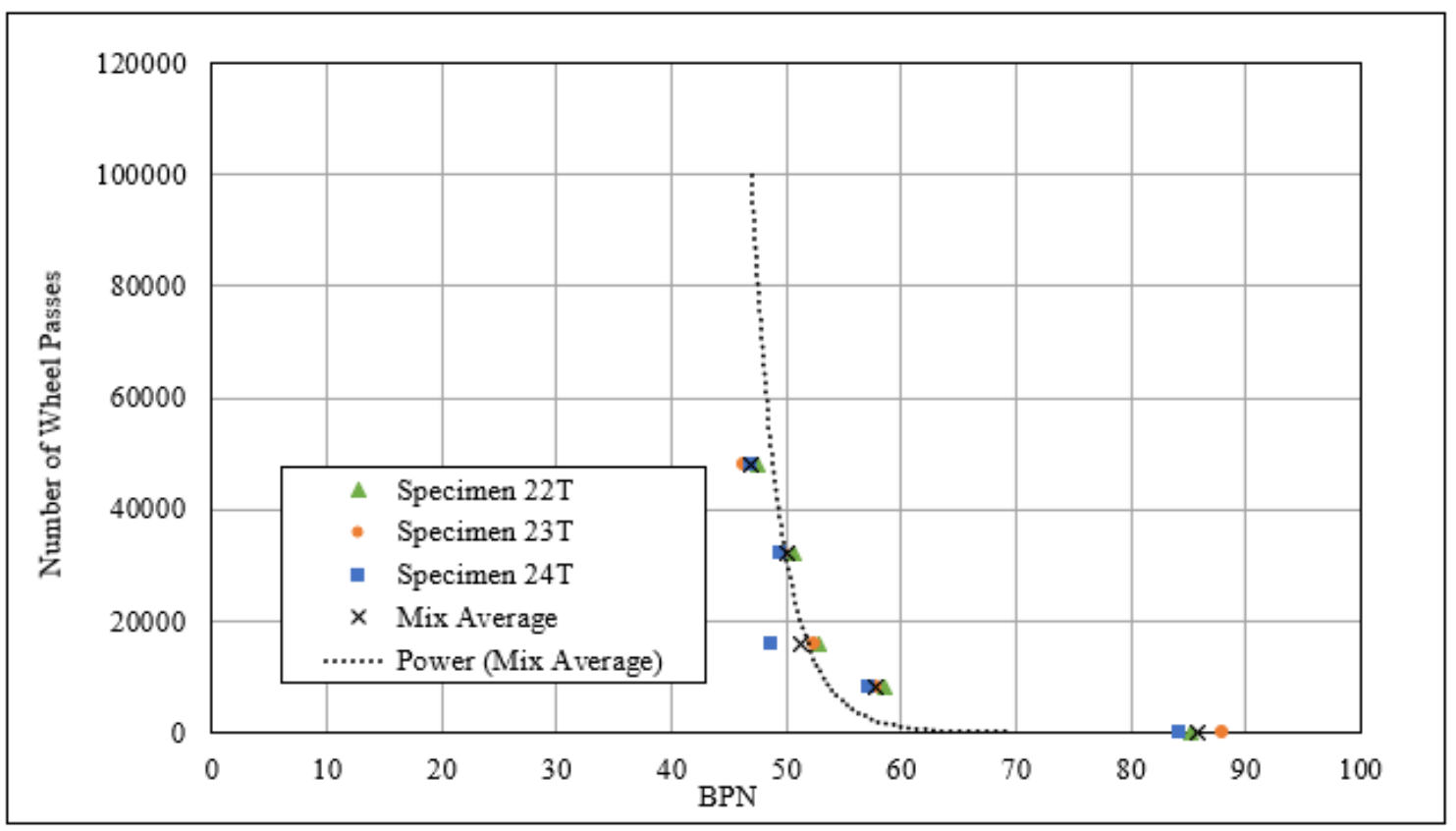

Figure 52: Trial 4 Prediction of Required Wheel Passes at BPN Limits for WVP 12.5mm SR Specimens (Top Surfaces) at 8\% VTM After 48,000 Wheel Passes 


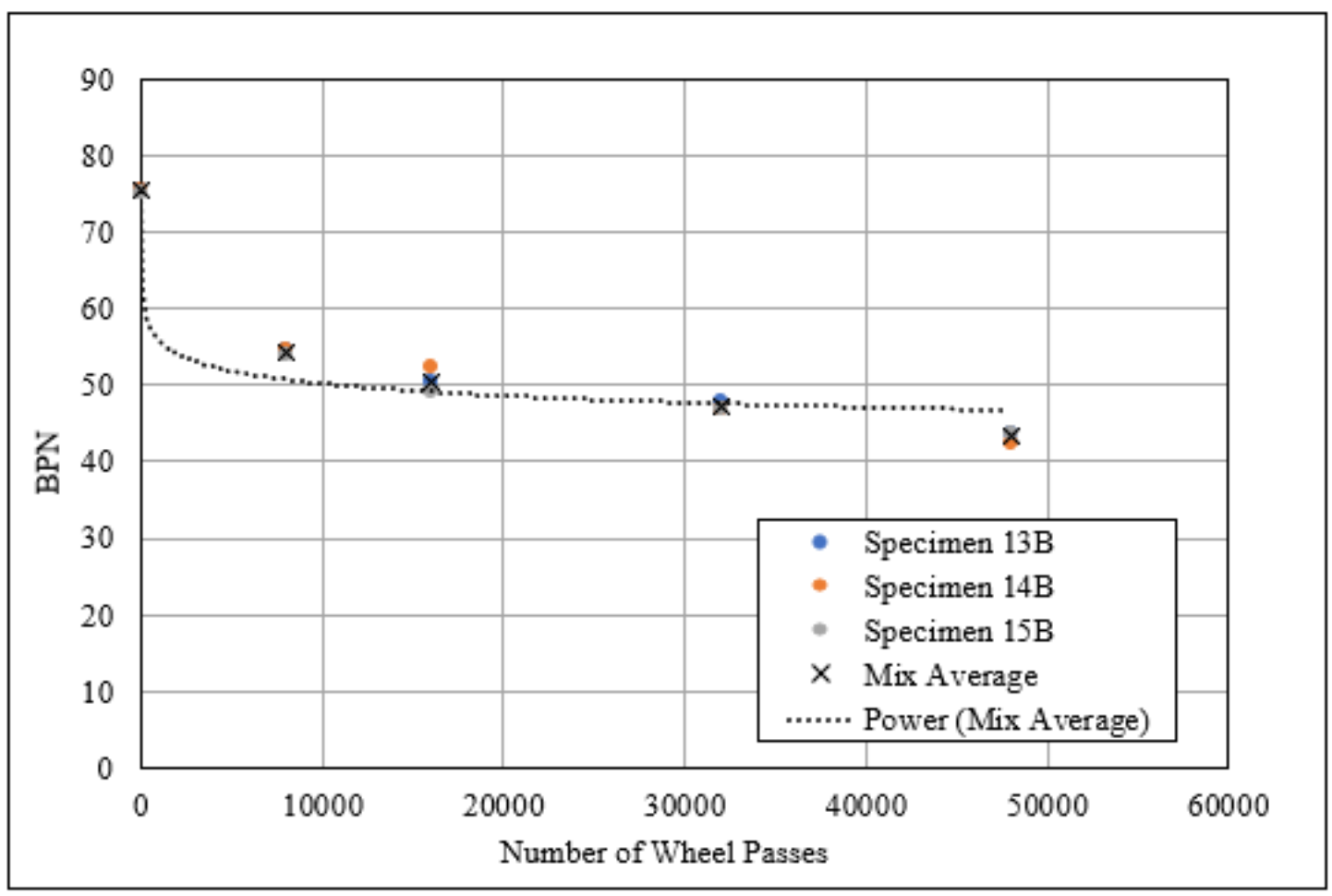

Figure 53: Trial 5 Average BPN Trend for Greer W1H Specimens (Bottom Surfaces) at 8\% VTM After 48,000 Wheel Passes

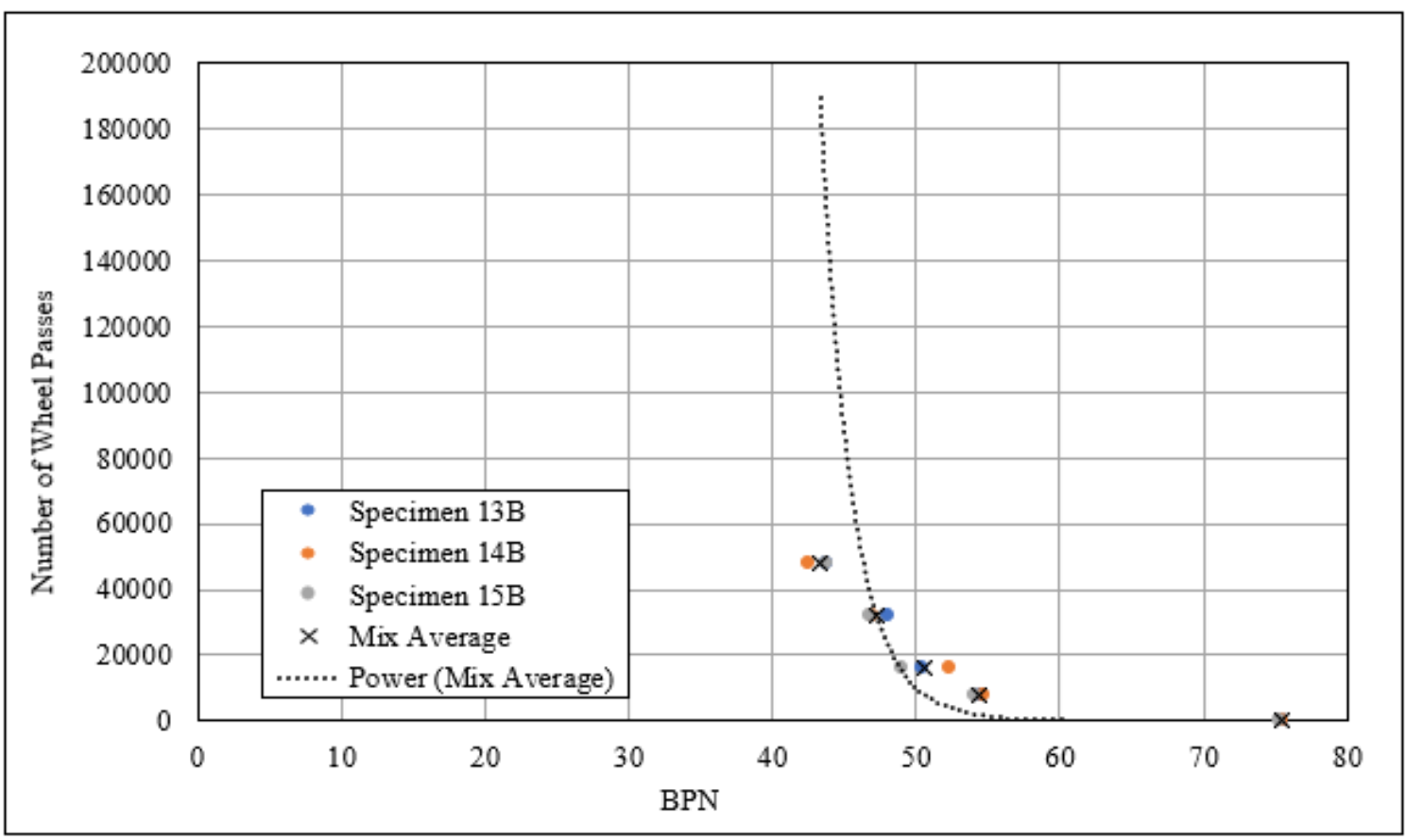

Figure 54: Trial 5 Prediction of Required Wheel Passes at BPN Limits for Greer W1H Specimens (Bottom Surfaces) at 8\% VTM After 48,000 Wheel Passes 


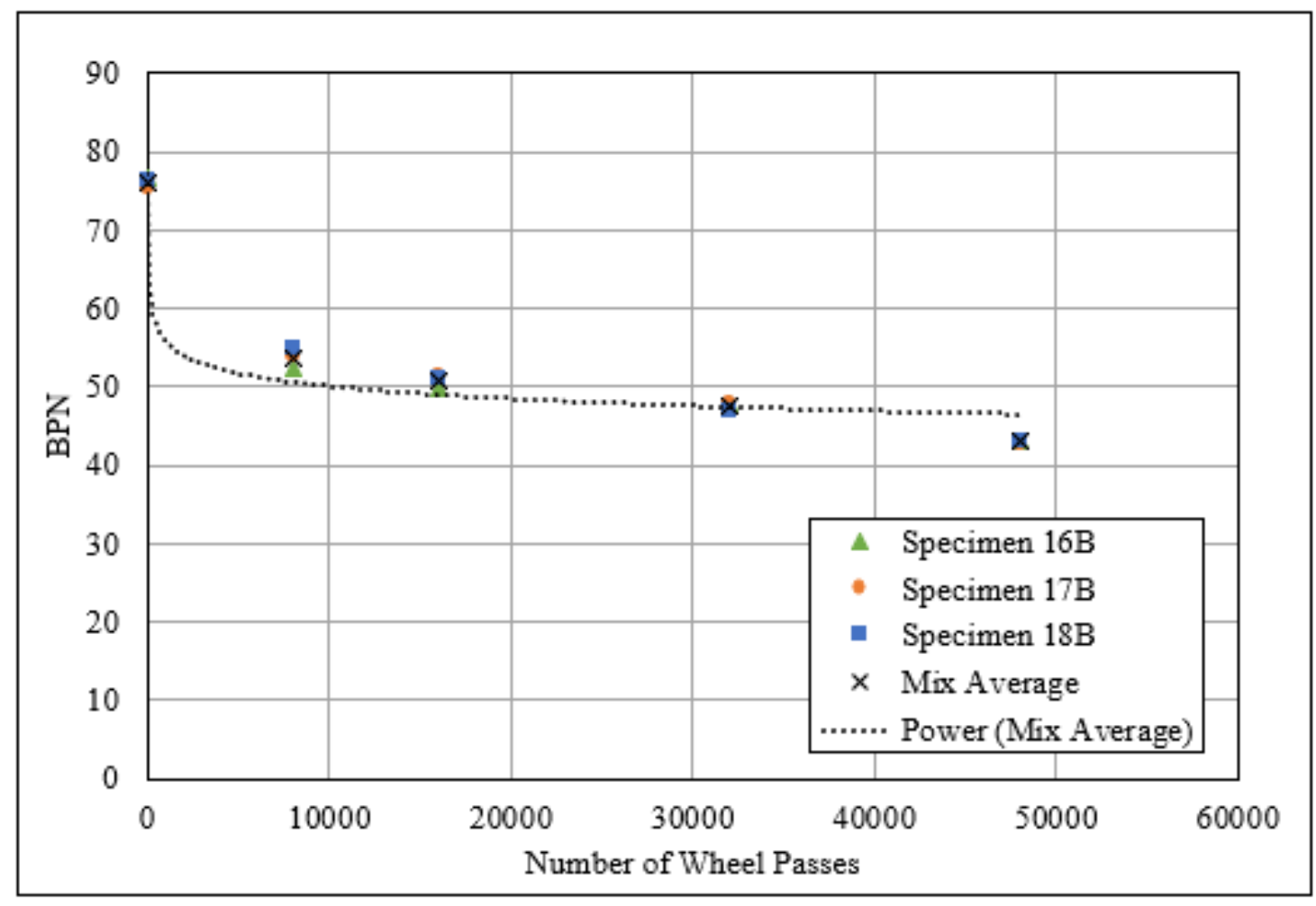

Figure 55: Trial 5 Average BPN Trend for Greer W1H Specimens (Bottom Surfaces) at 4\% VTM After 48,000 Wheel Passes

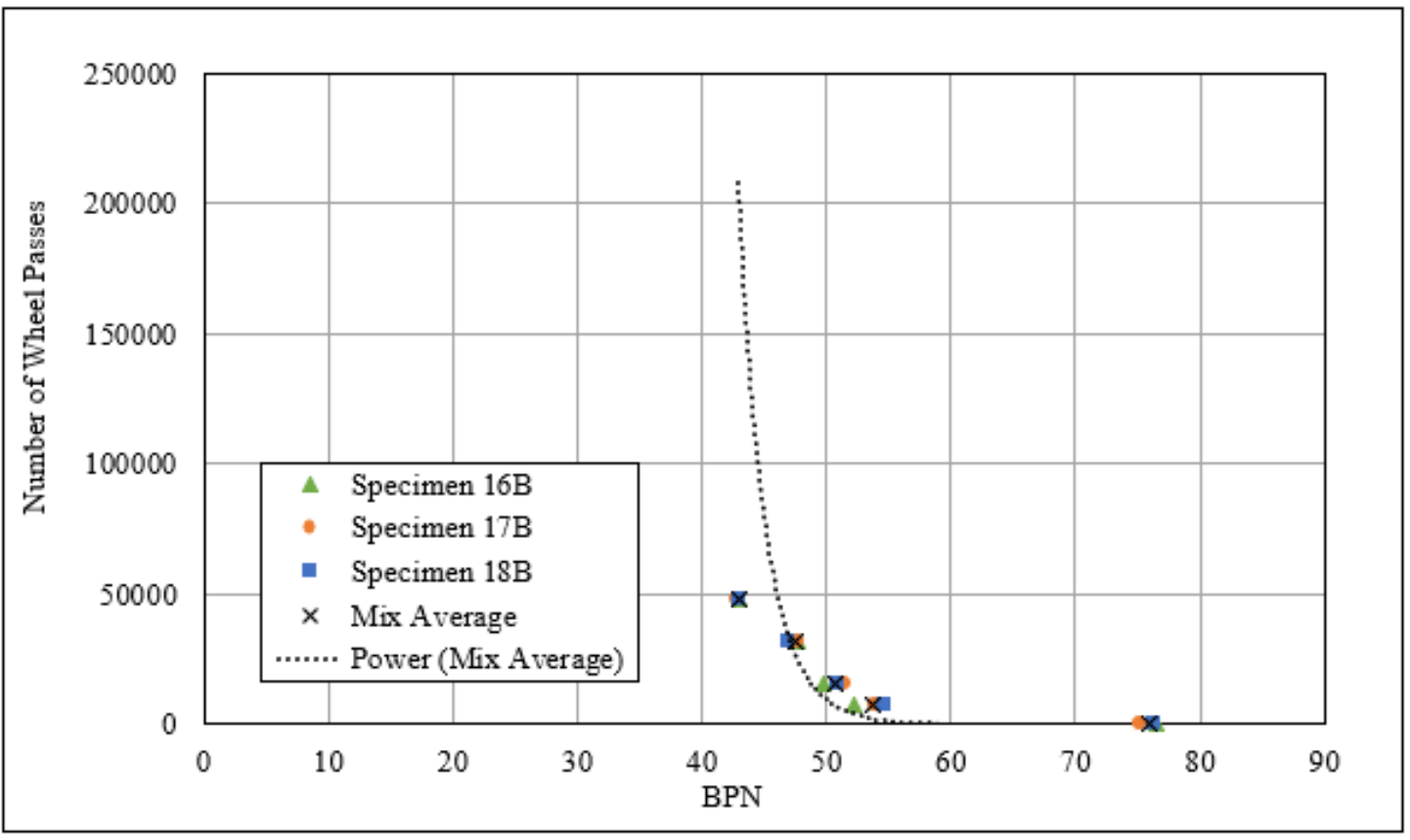

Figure 56: Trial 5 Prediction of Required Wheel Passes at BPN Limits for Greer W1H Specimens (Bottom Surfaces) at 4\% VTM After 48,000 Wheel Passes 


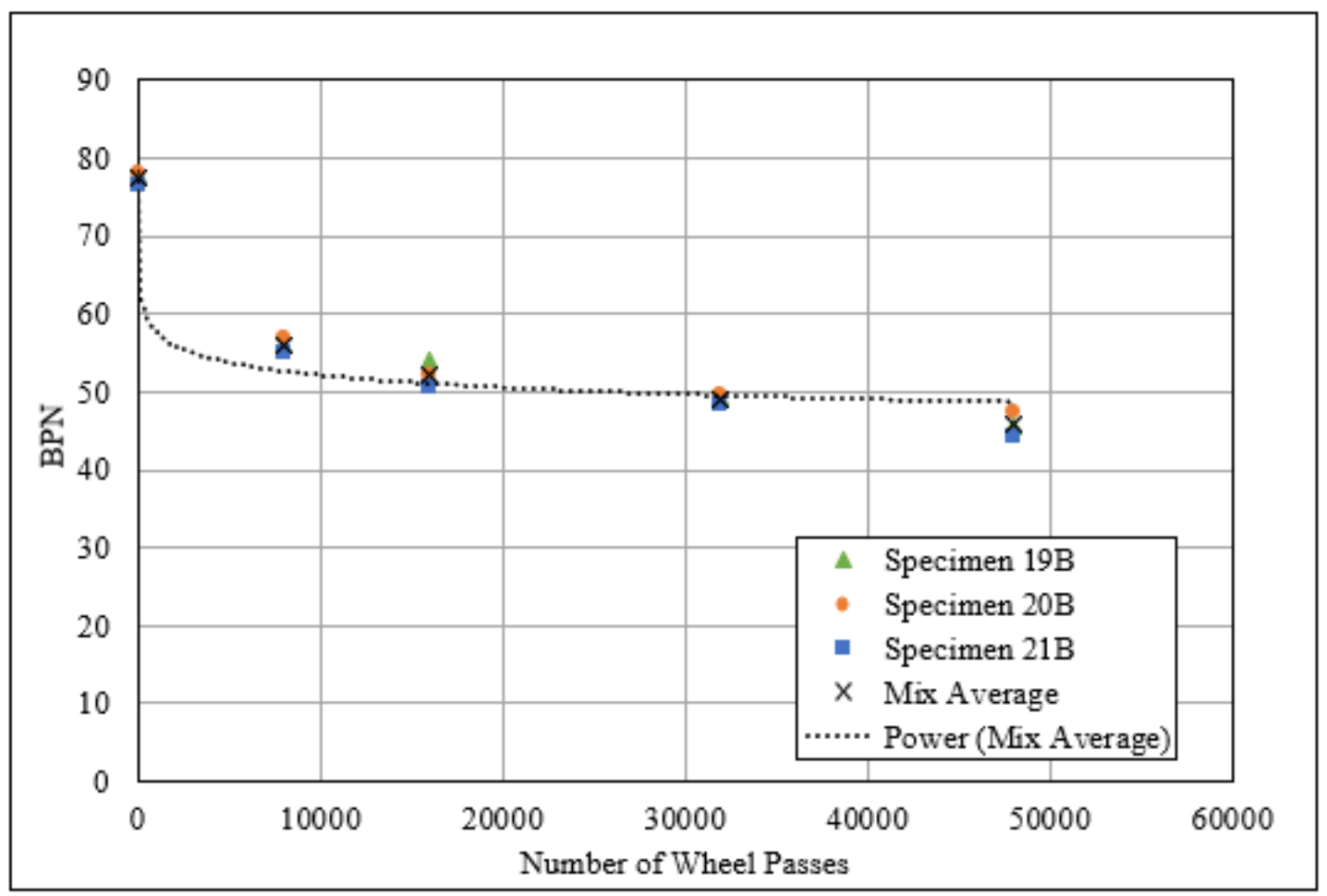

Figure 57: Trial 5 Average BPN Trend for WVP 12.5mm SR Specimens (Bottom Surfaces) at 4\% VTM After 48,000 Wheel Passes

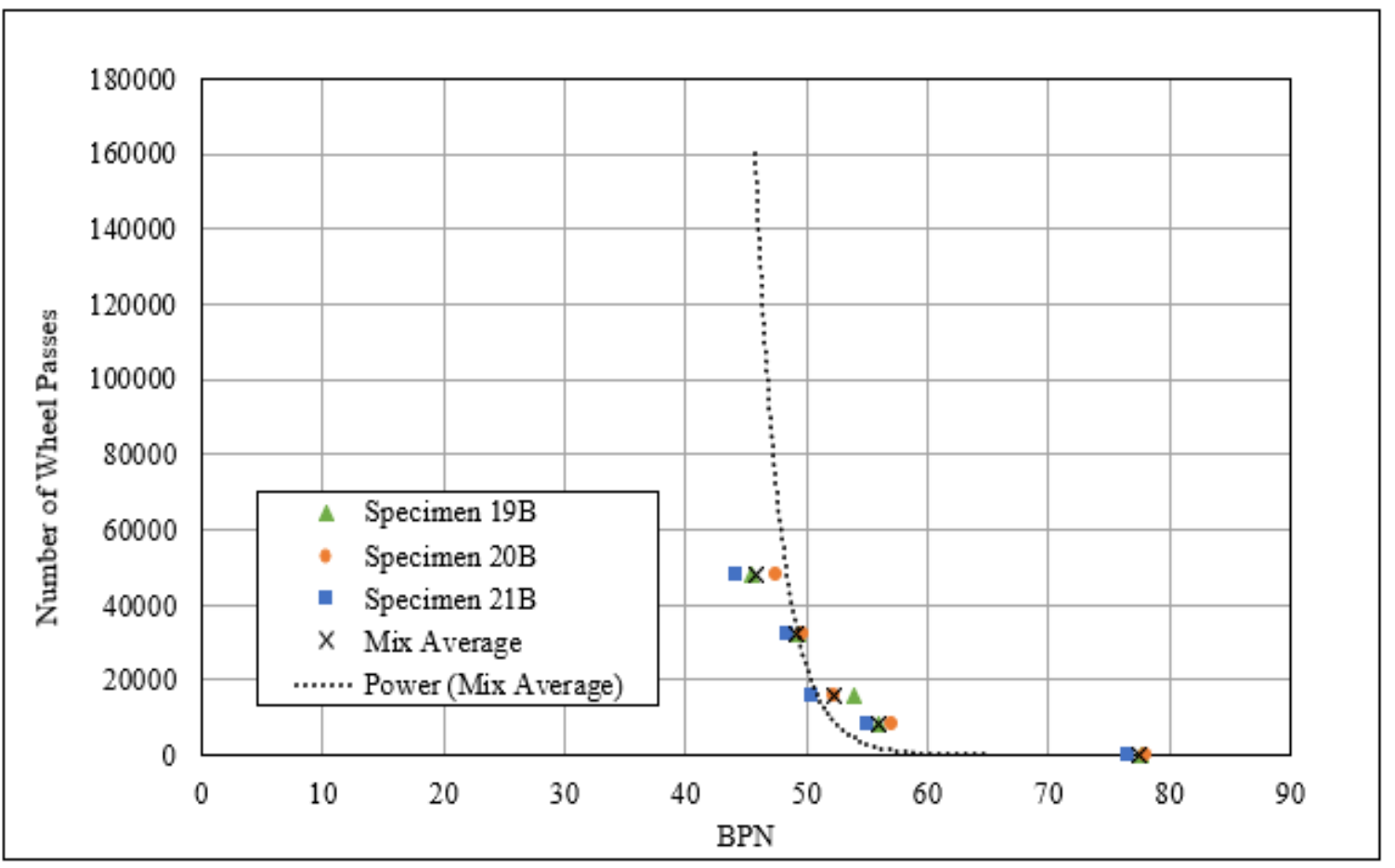

Figure 58: Trial 5 Prediction of Required Wheel Passes at BPN Limits for WVP 12.5mm SR Specimens (Bottom Surfaces) at 4\% VTM After 48,000 Wheel Passes 


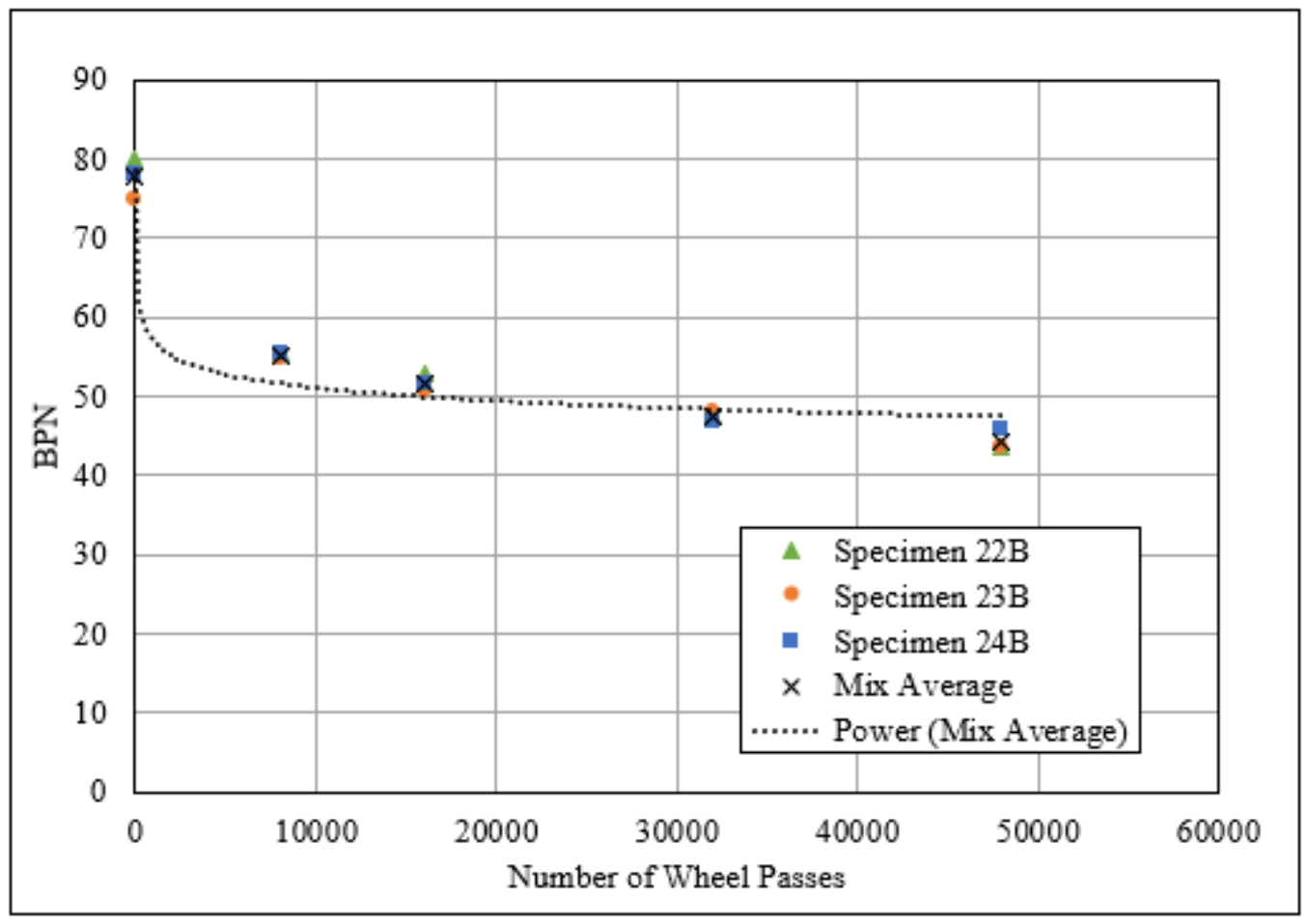

Figure 59: Trial 5 Average BPN Trend for WVP 12.5mm SR Specimens (Bottom Surfaces) at 8\% VTM After 48,000 Wheel Passes

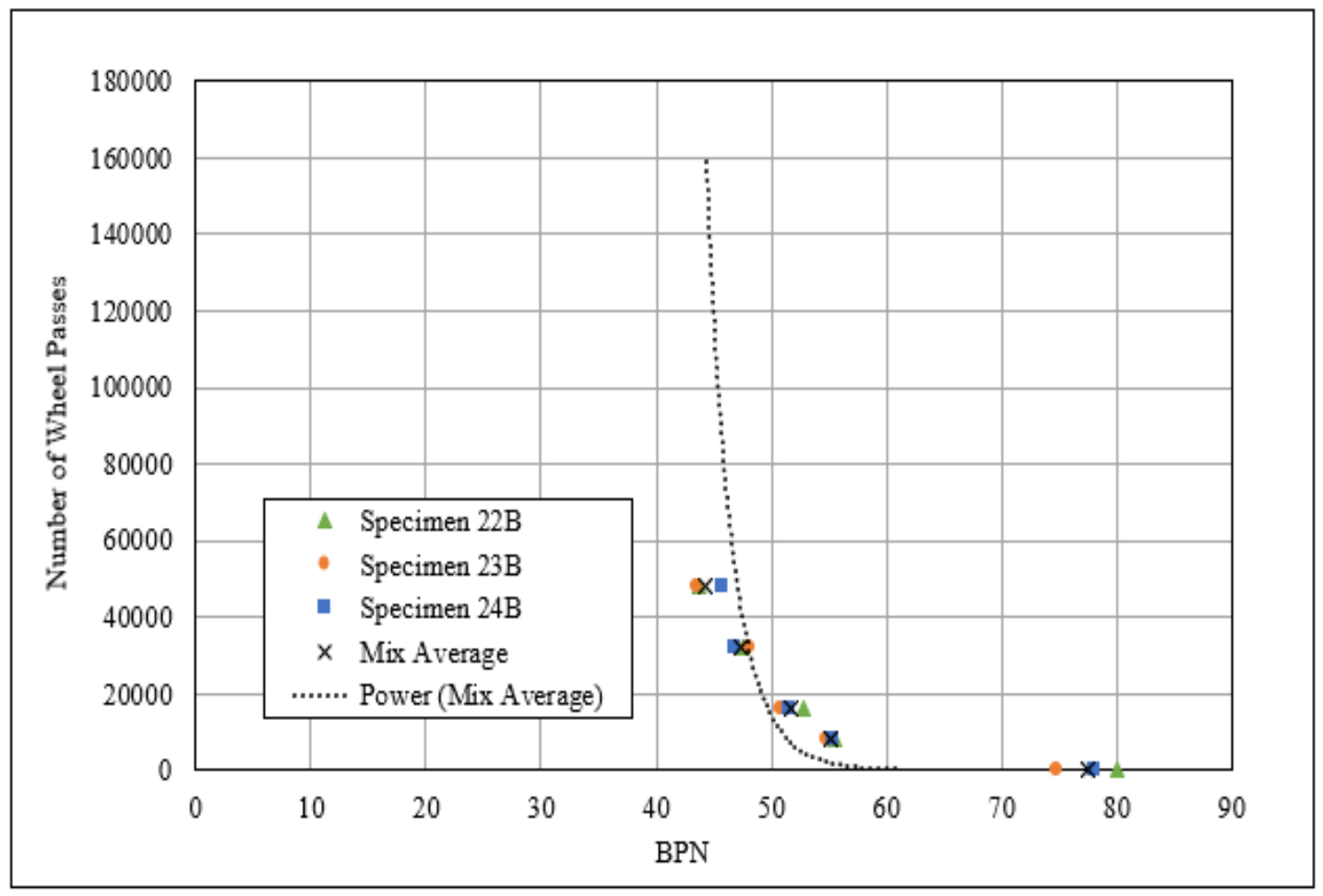

Figure 60: Trial 5 Prediction of Required Wheel Passes at BPN Limits for WVP 12.5mm SR Specimens (Bottom Surfaces) at 8\% VTM After 48,000 Wheel Passes 


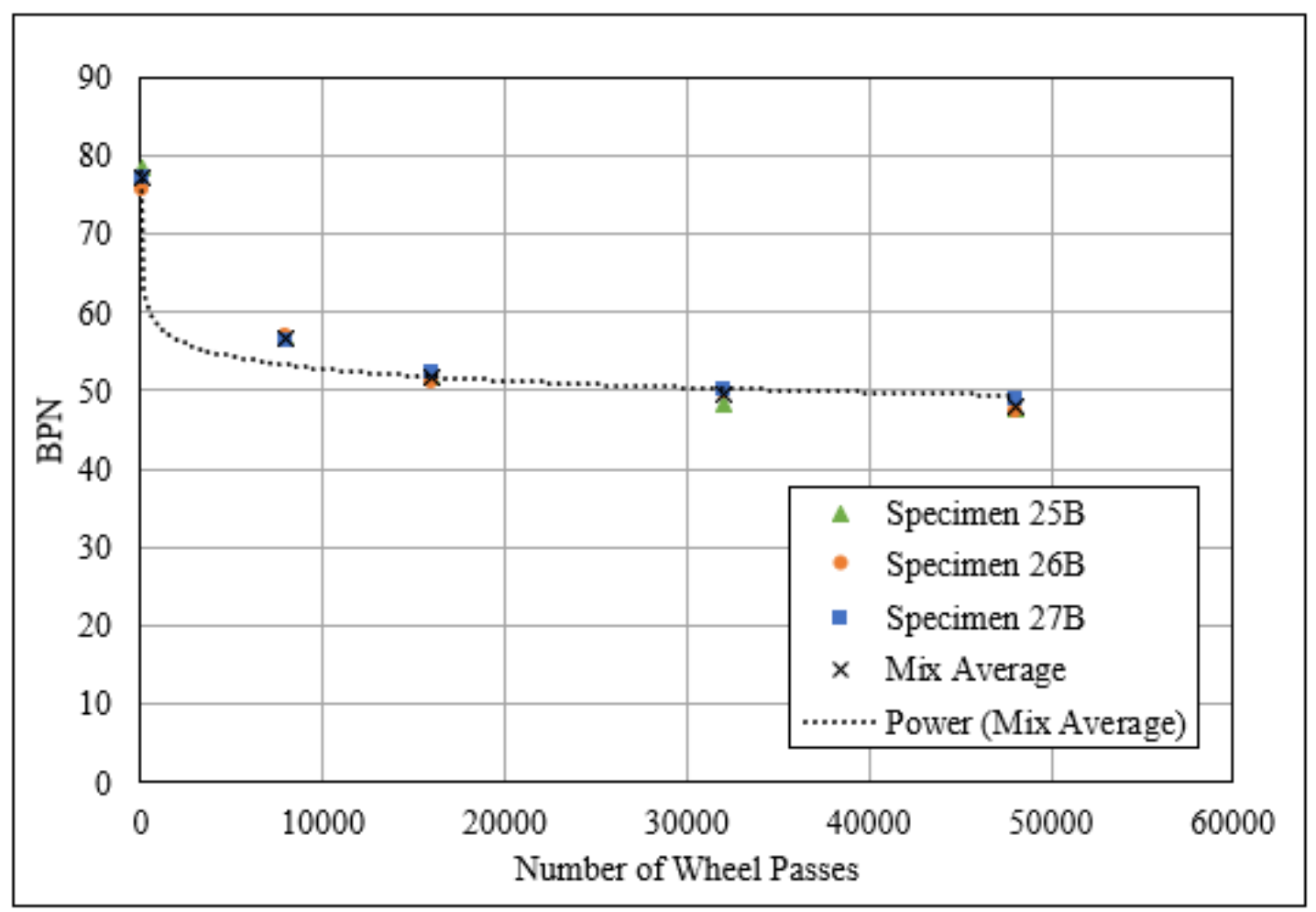

Figure 61: Trial 6 Average BPN Trend for JFA 12.5mm SR Specimens (Bottom Surfaces) at 4\% VTM After 48,000 Wheel Passes

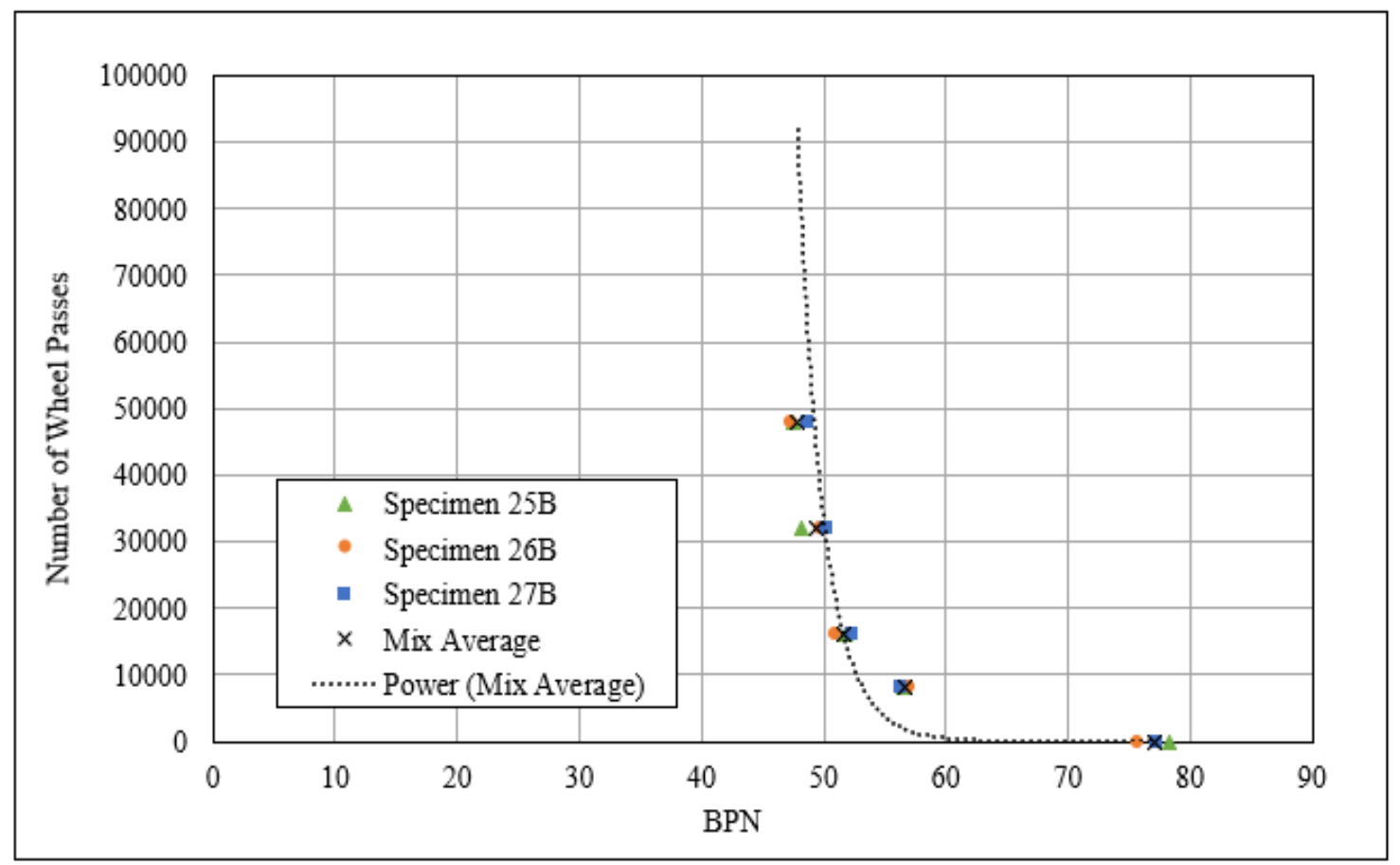

Figure 62: Trial 6 Prediction of Required Wheel Passes at BPN Limits for JFA 12.5mm SR Specimens (Bottom Surfaces) at 4\% VTM After 48,000 Wheel Passes 


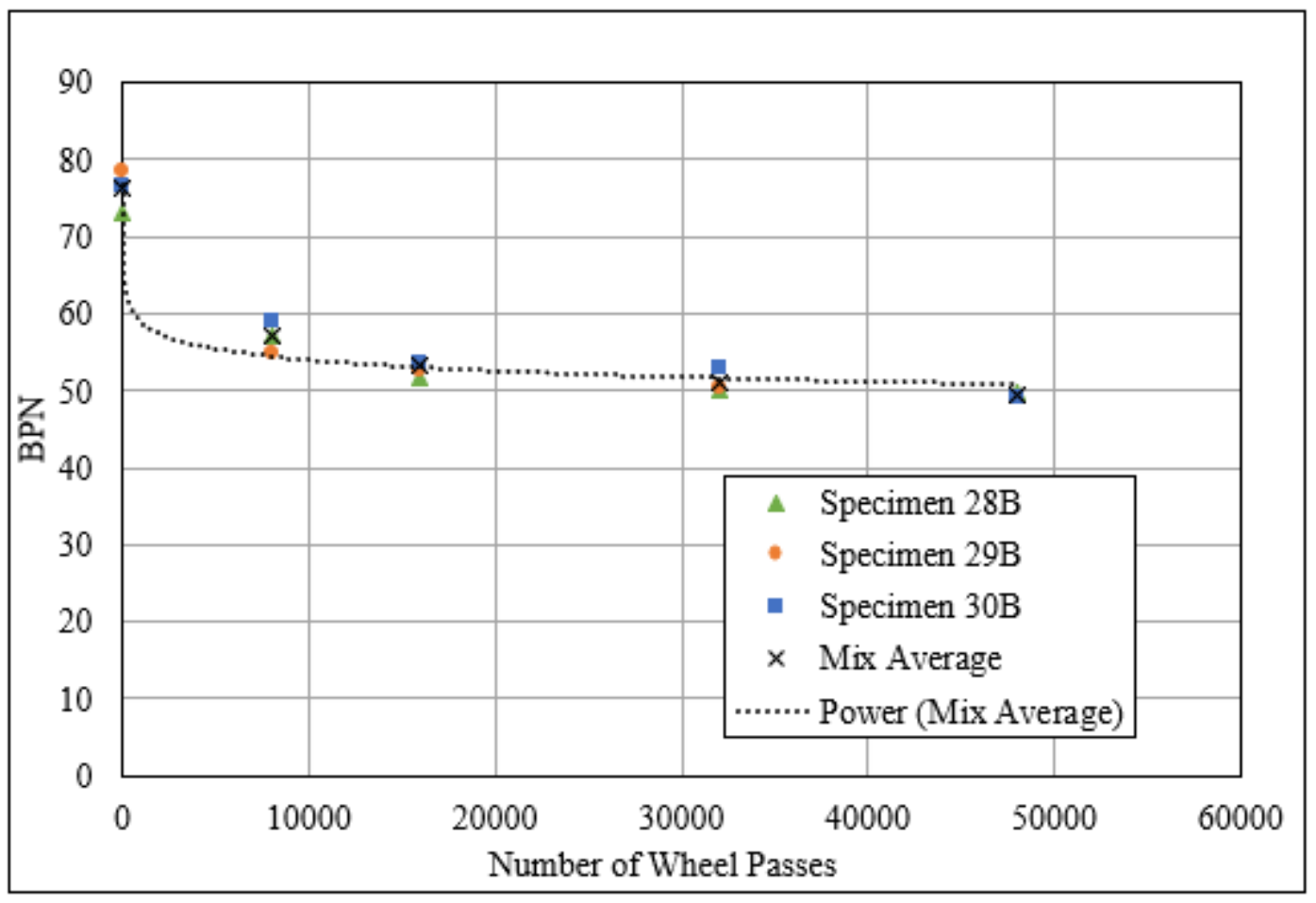

Figure 63: Trial 6 Average BPN Trend for JFA 12.5mm SR Specimens (Bottom Surfaces) at 8\% VTM After 48,000 Wheel Passes

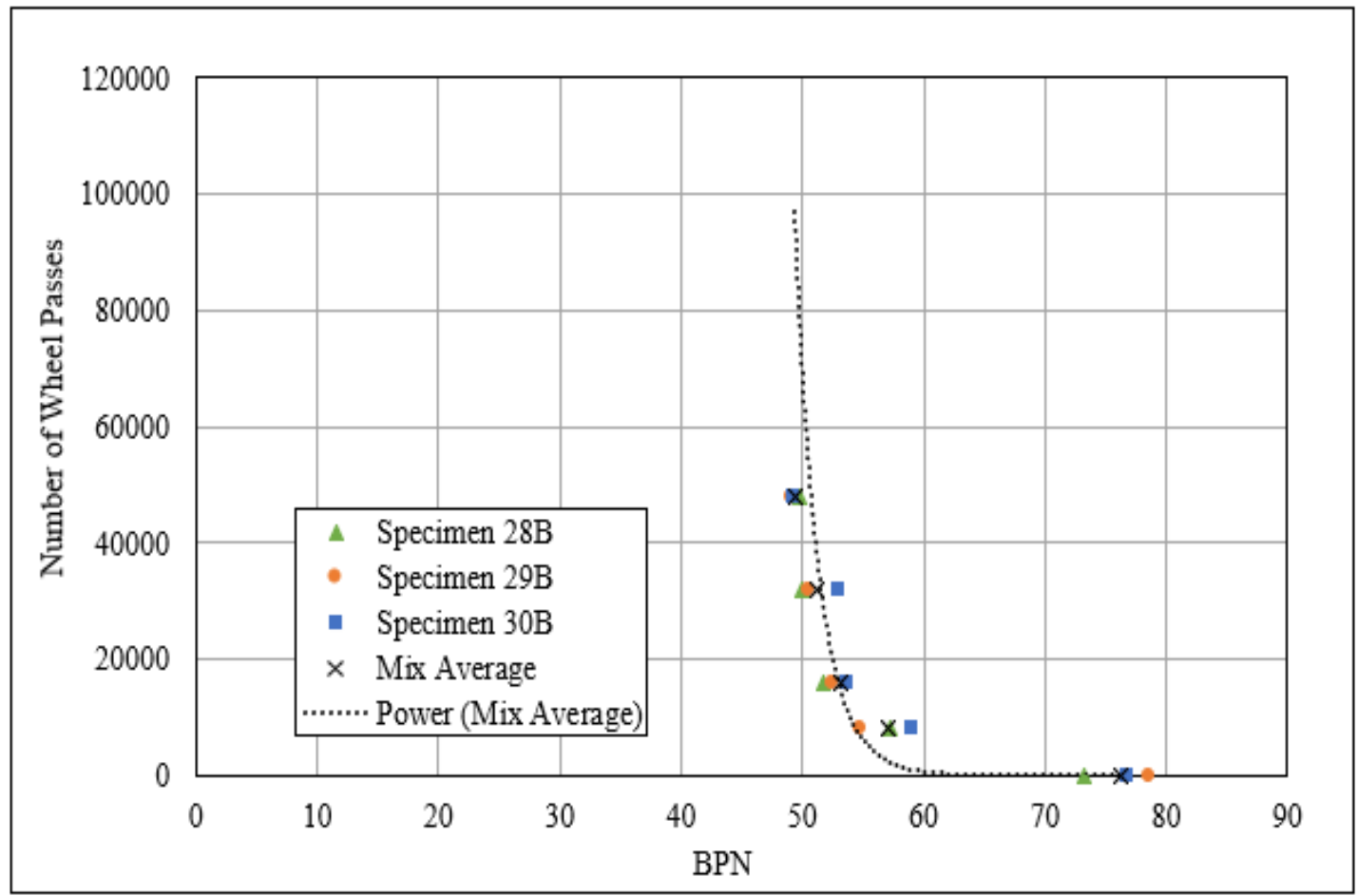

Figure 64: Trial 6 Prediction of Required Wheel Passes at BPN Limits for JFA 12.5mm SR Specimens (Bottom Surfaces) at 8\% VTM After 48,000 Wheel Passes 


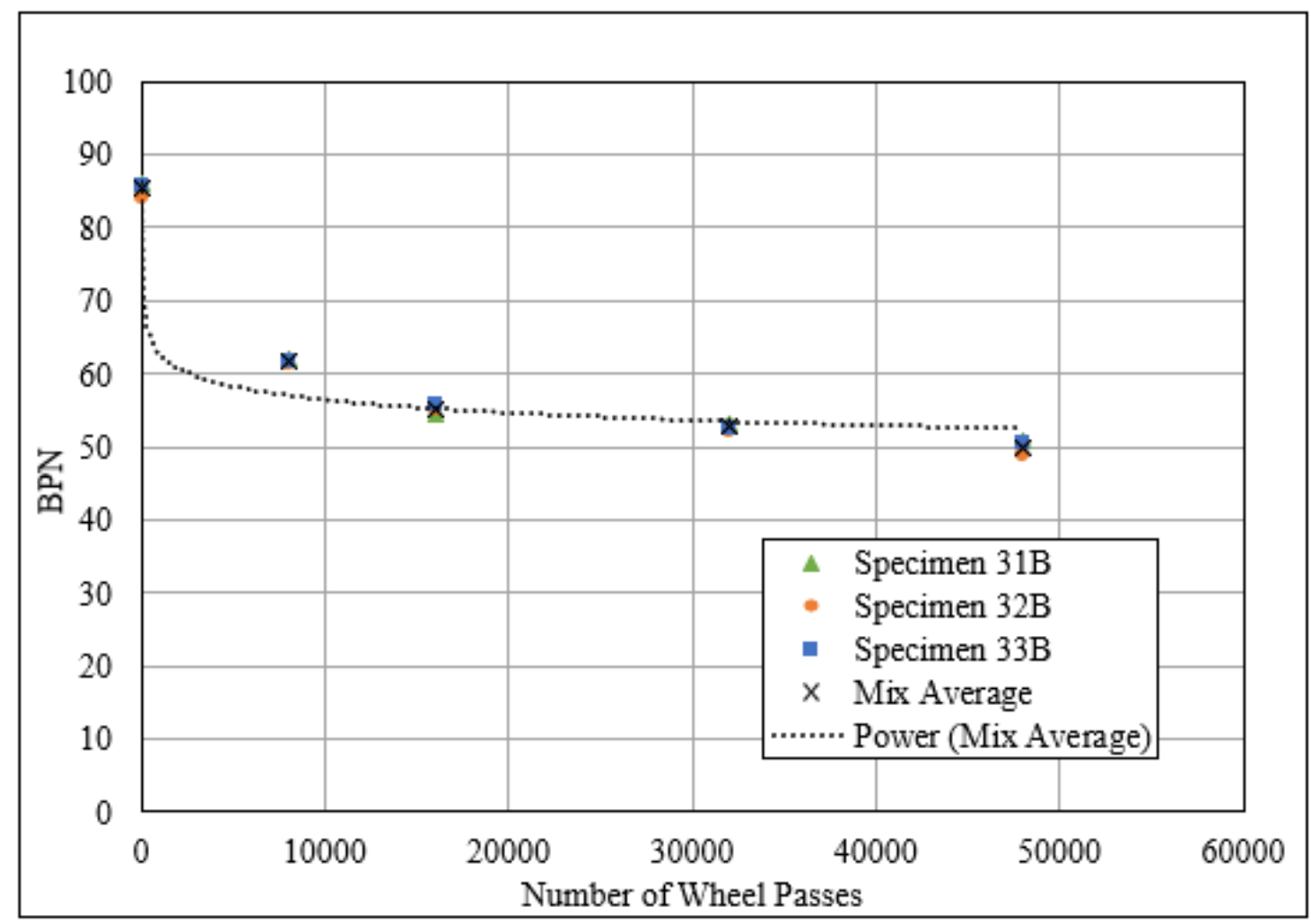

Figure 65: Trial 6 Average BPN Trend for WVP W1-RAP Specimens (Bottom Surfaces) at 4\% VTM After 48,000 Wheel Passes

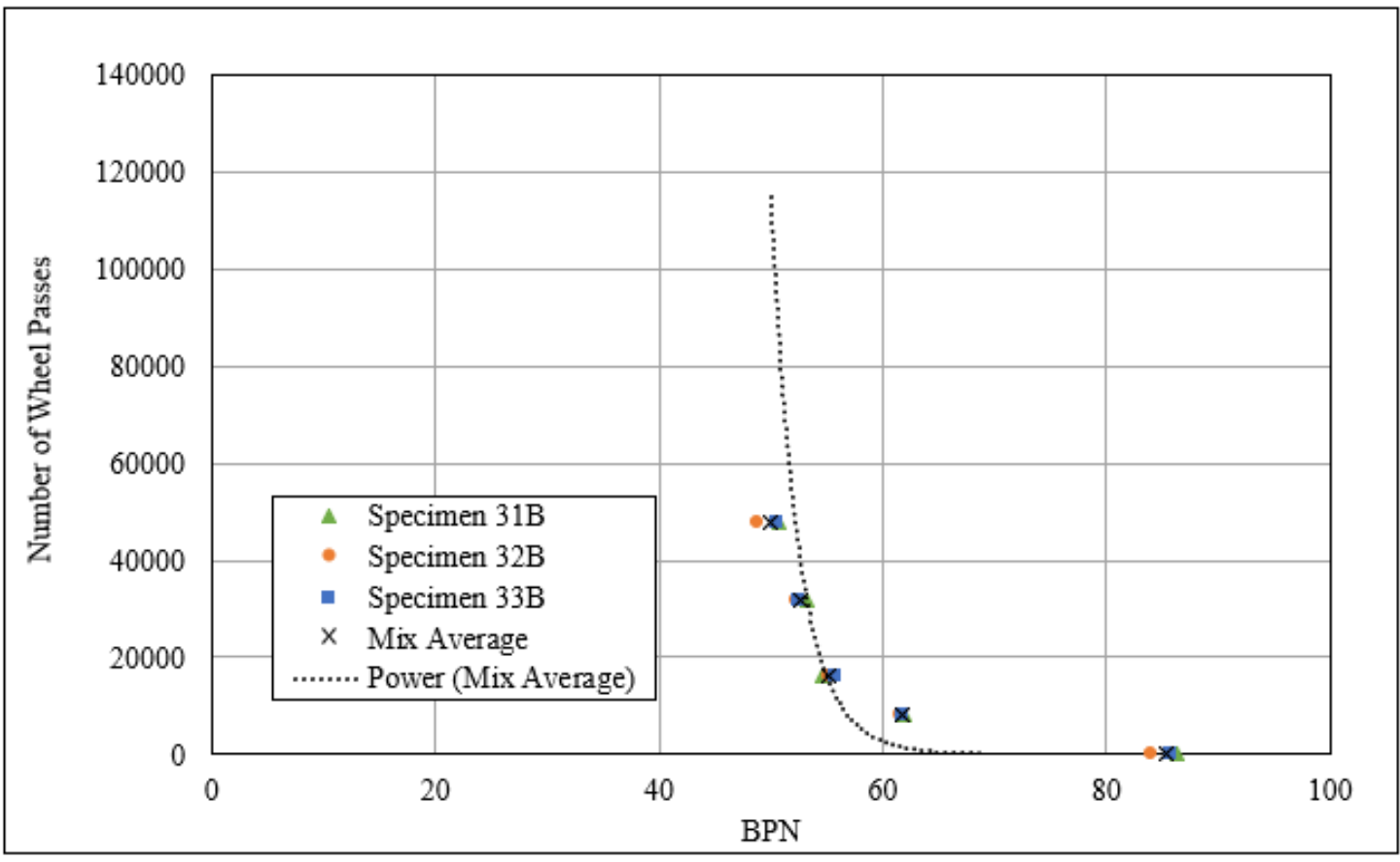

Figure 66: Trial 6 Prediction of Required Wheel Passes at BPN Limits for WVP W1-RAP Specimens (Bottom Surfaces) at 4\% VTM After 48,000 Wheel Passes 


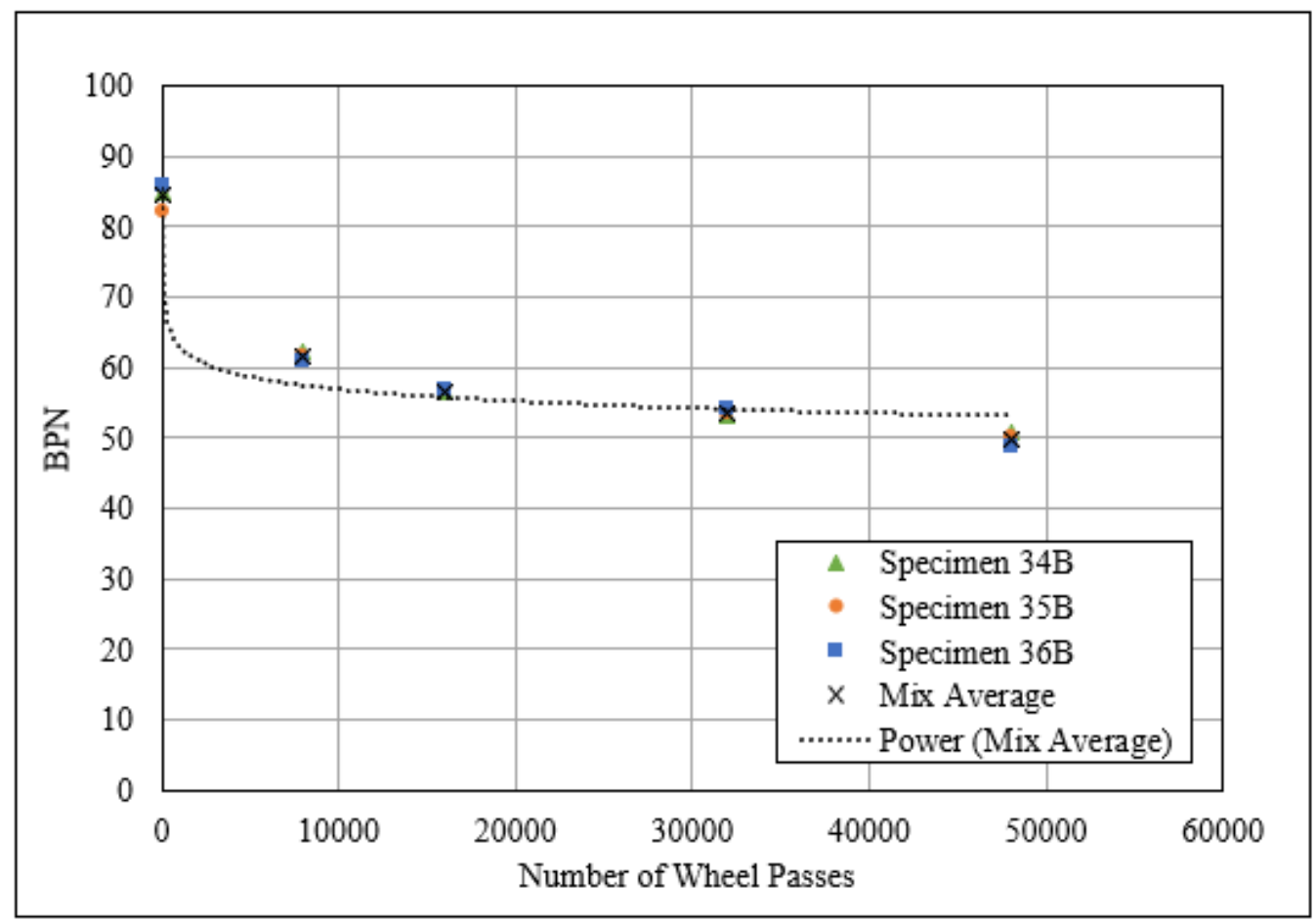

Figure 67: Trial 6: Average BPN Trend for WVP W1-RAP Specimens (Bottom Surfaces) at 8\% VTM After 48,000 Wheel Passes

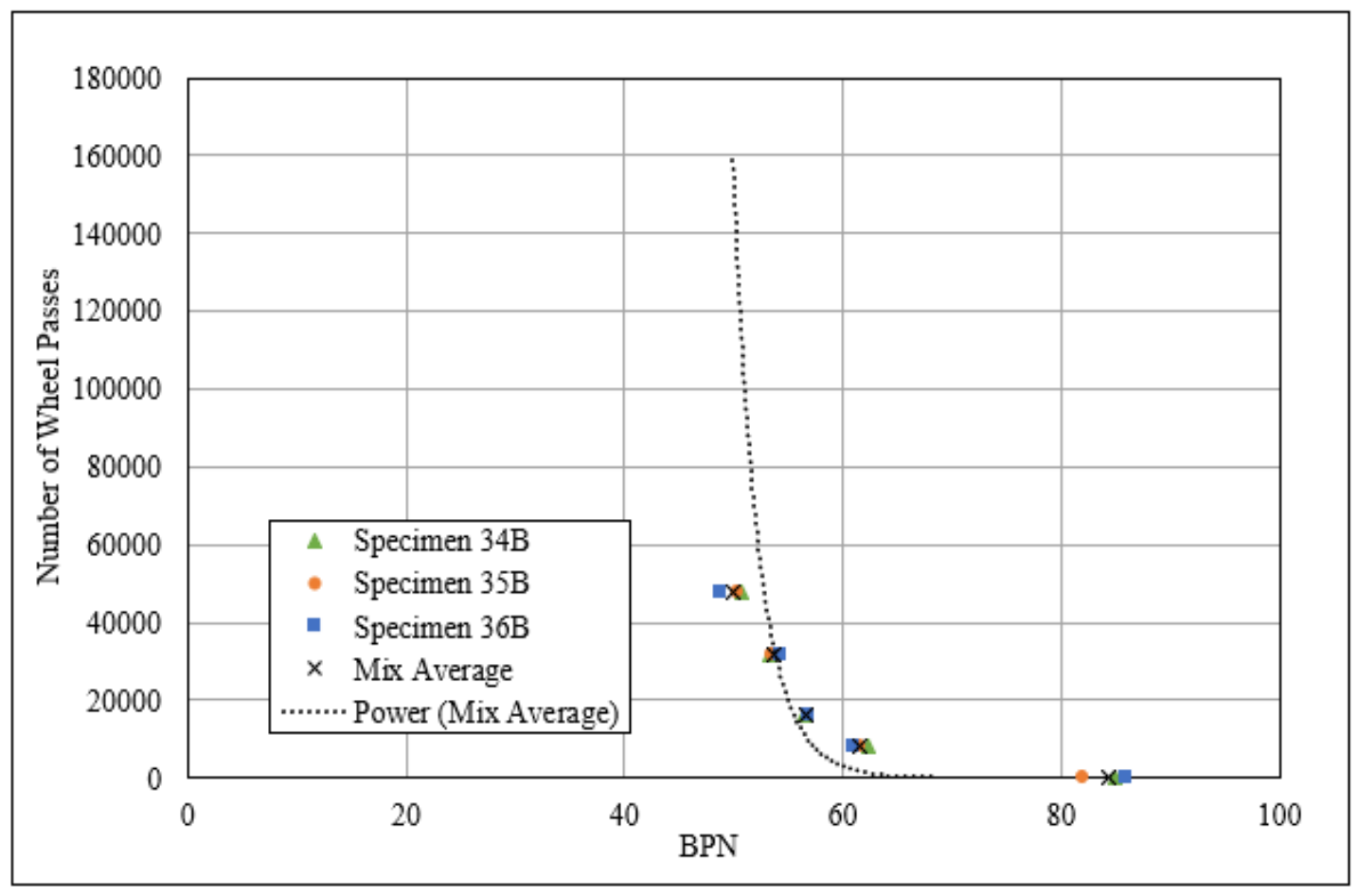

Figure 68: Trial 6 Prediction of Required Wheel Passes at BPN Limits for WVP W1-RAP Specimens (Bottom Surfaces) at 8\% VTM After 48,000 Wheel Passes 


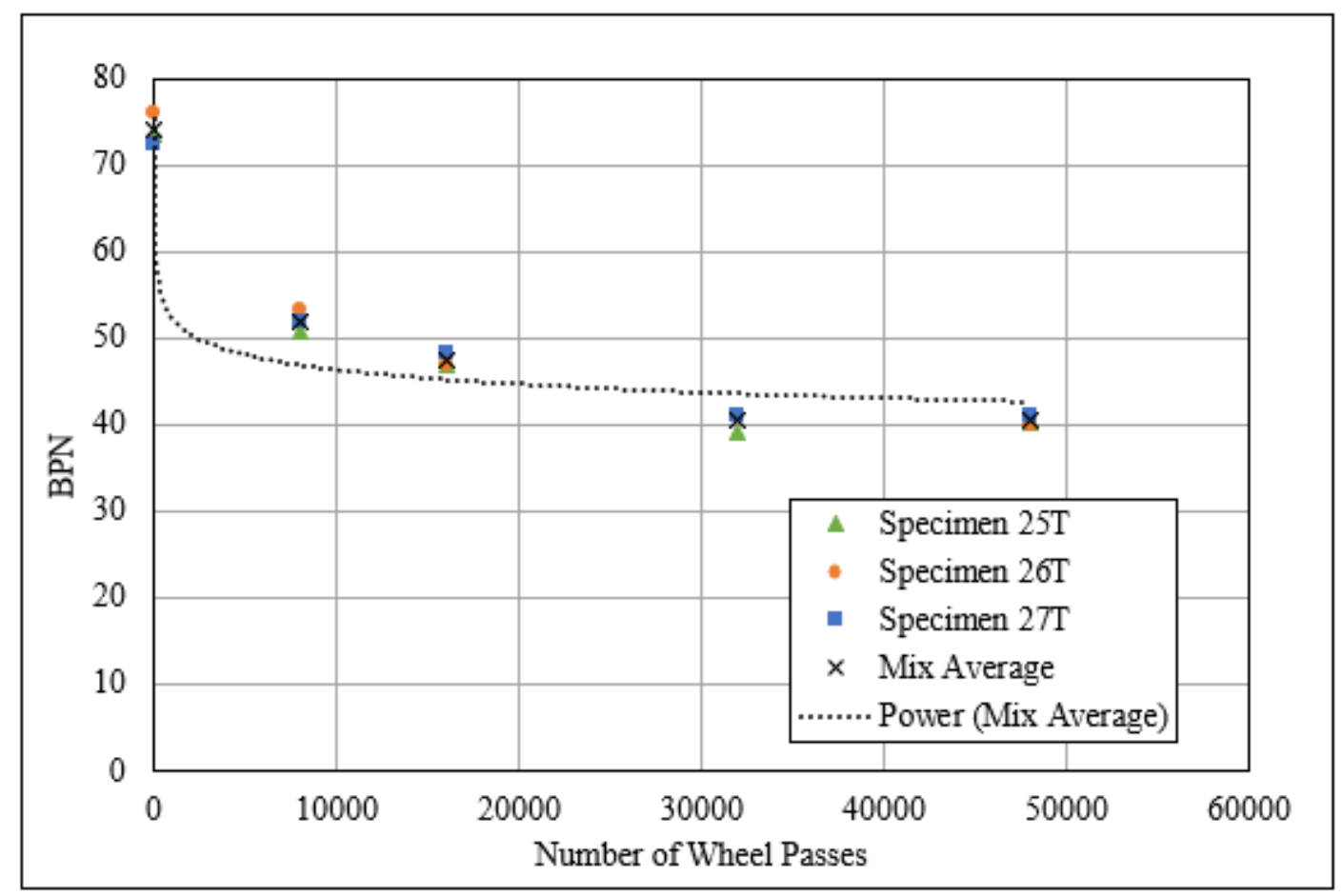

Figure 69: Trial 7 Average BPN Trend for JFA 12.5mm SR Specimens (Top Surfaces) at 4\% VTM After 48,000 Wheel Passes

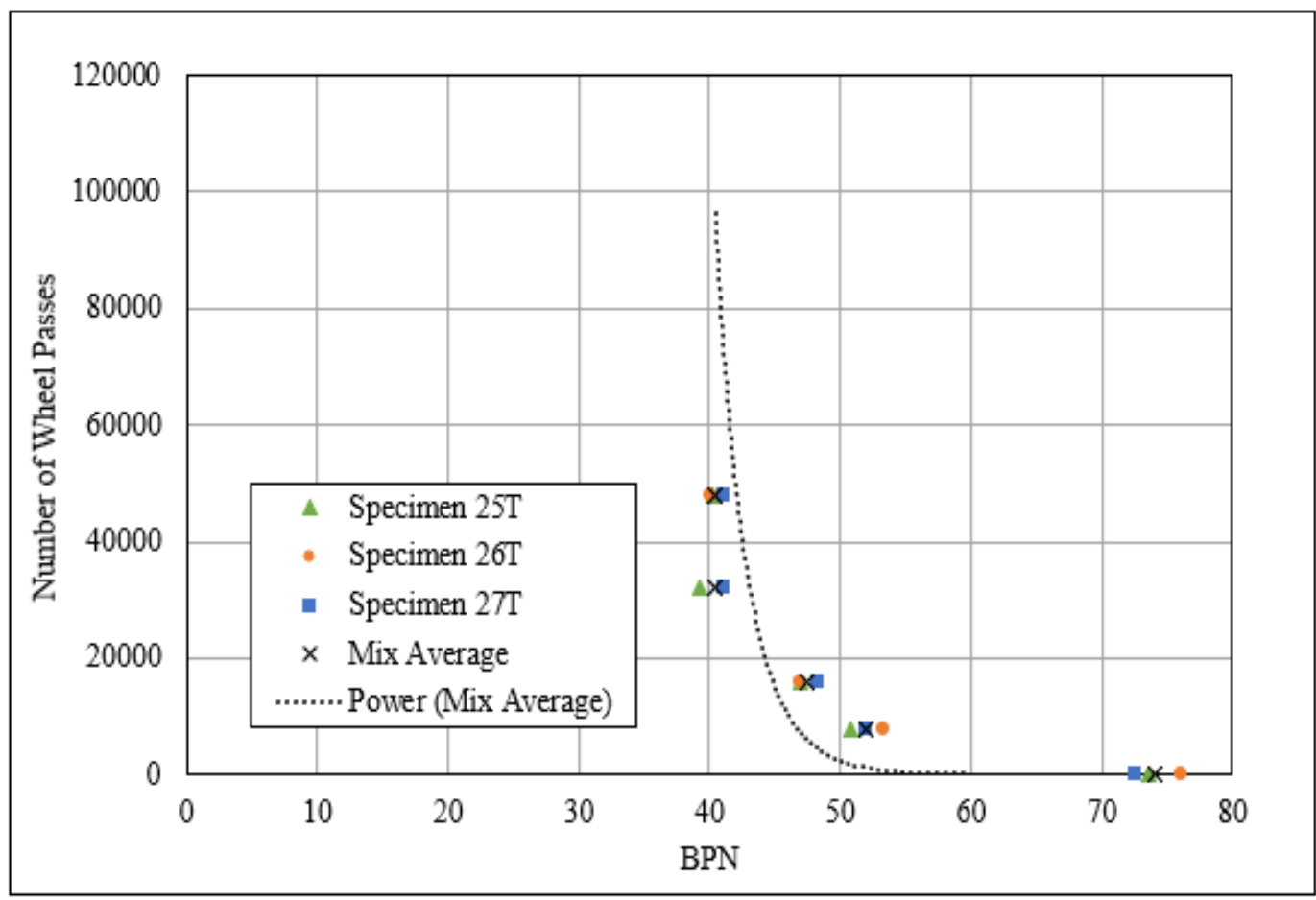

Figure 70: Trial 7 Prediction of Required Wheel Passes at BPN Limits for JFA 12.5mm SR Specimens (Top Surfaces) at 4\% VTM After 48,000 Wheel Passes 


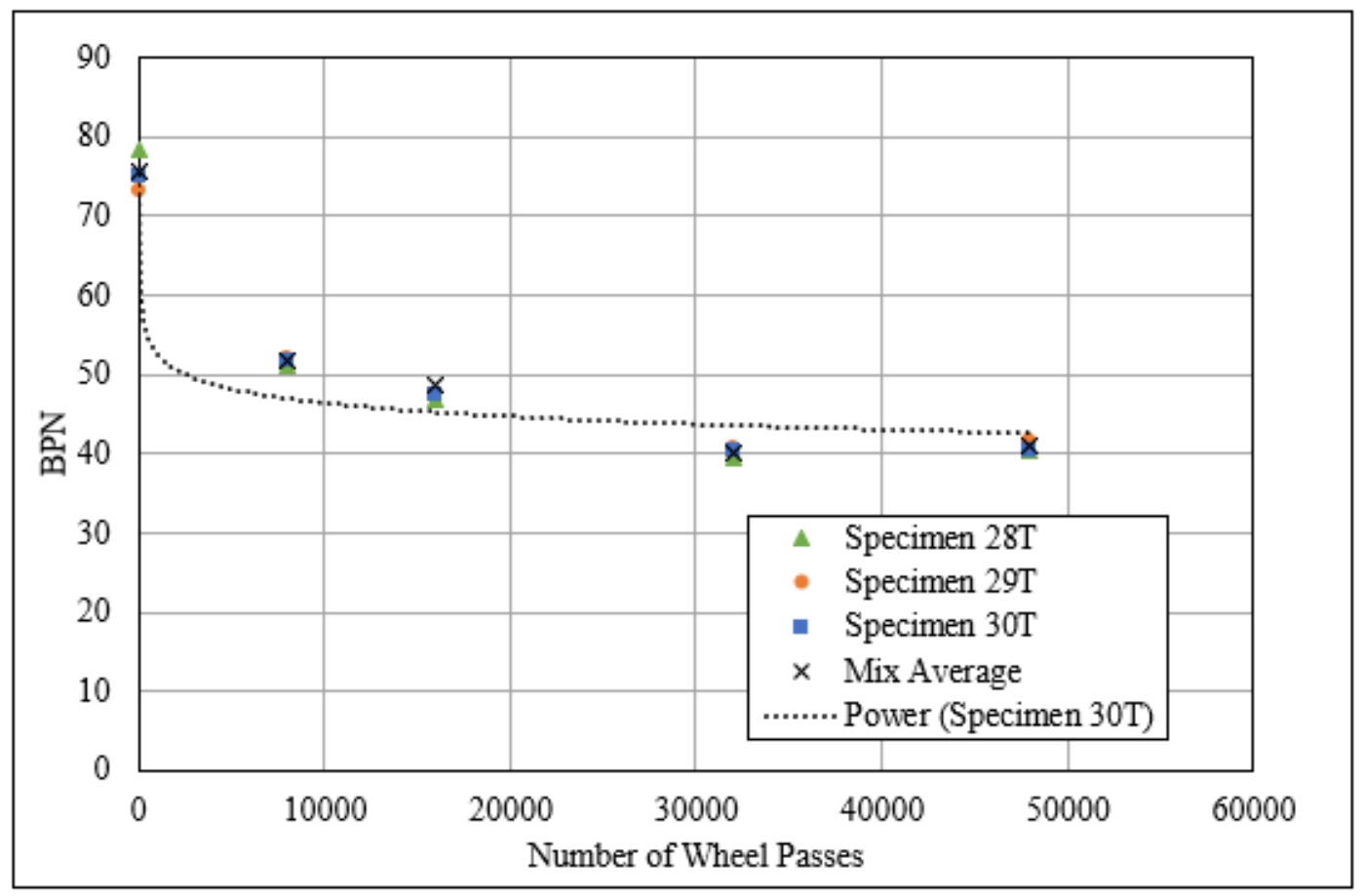

Figure 71: Trial 7 Average BPN Trend for JFA 12.5mm SR Specimens (Top Surfaces) at 8\% VTM After 48,000 Wheel Passes

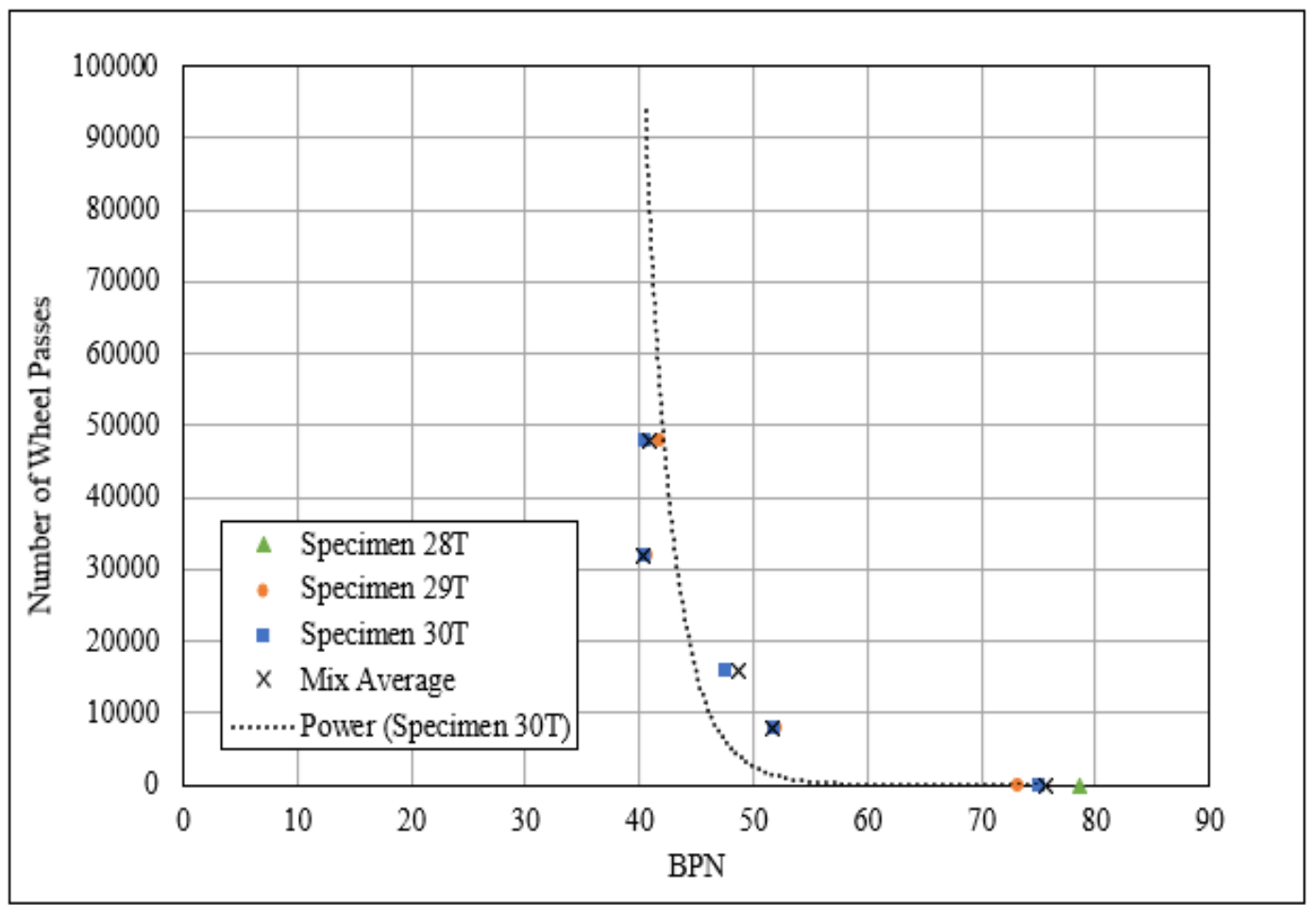

Figure 72: Trial 7 Prediction of Required Wheel Passes at BPN Limits for JFA 12.5mm SR Specimens (Top Surfaces) at 8\% VTM After 48,000 Wheel Passes 


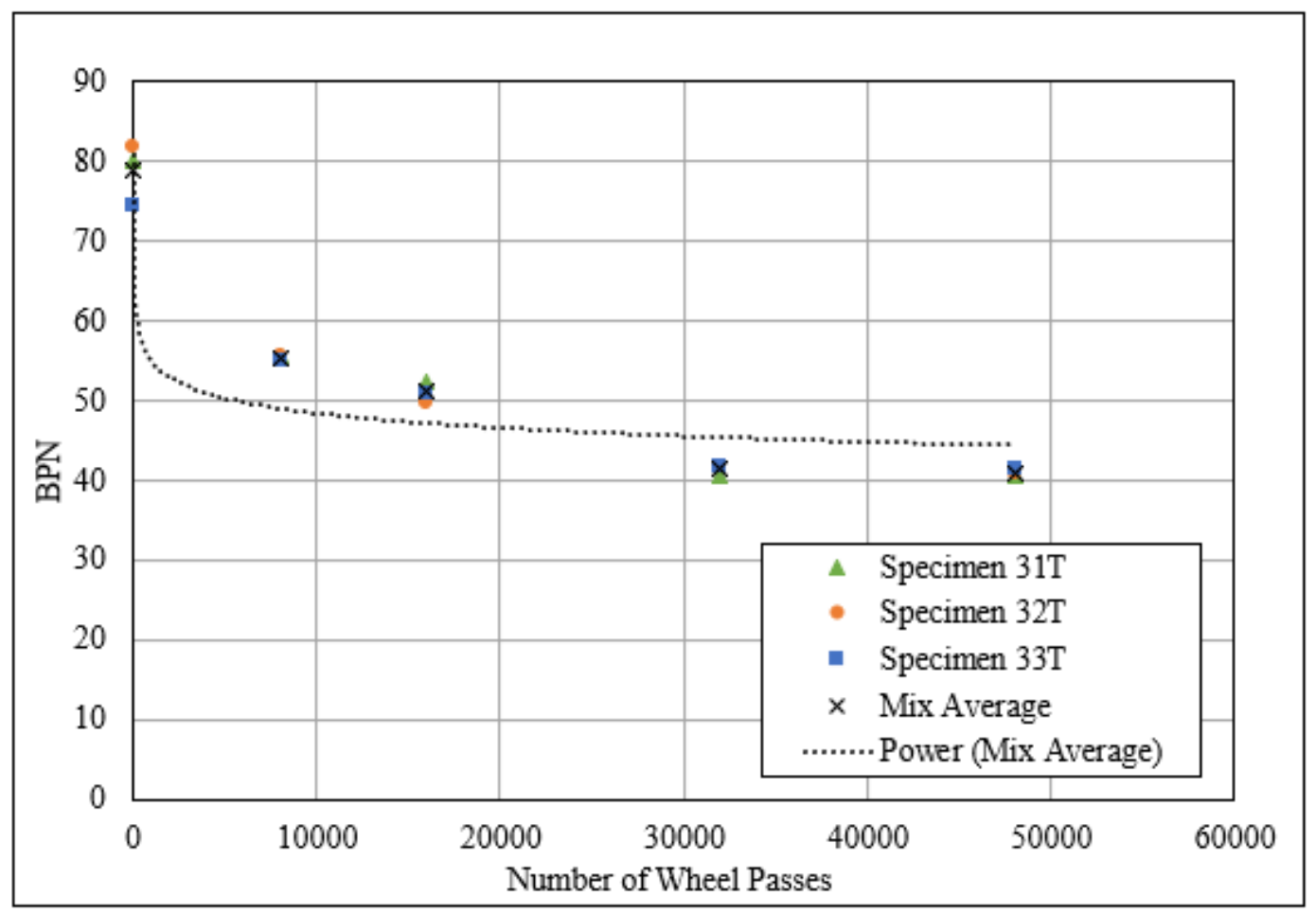

Figure 73: Trial 7 Average BPN Trend for WVP W1-RAP Specimens (Top Surfaces) at 4\% VTM After 48,000 Wheel Passes

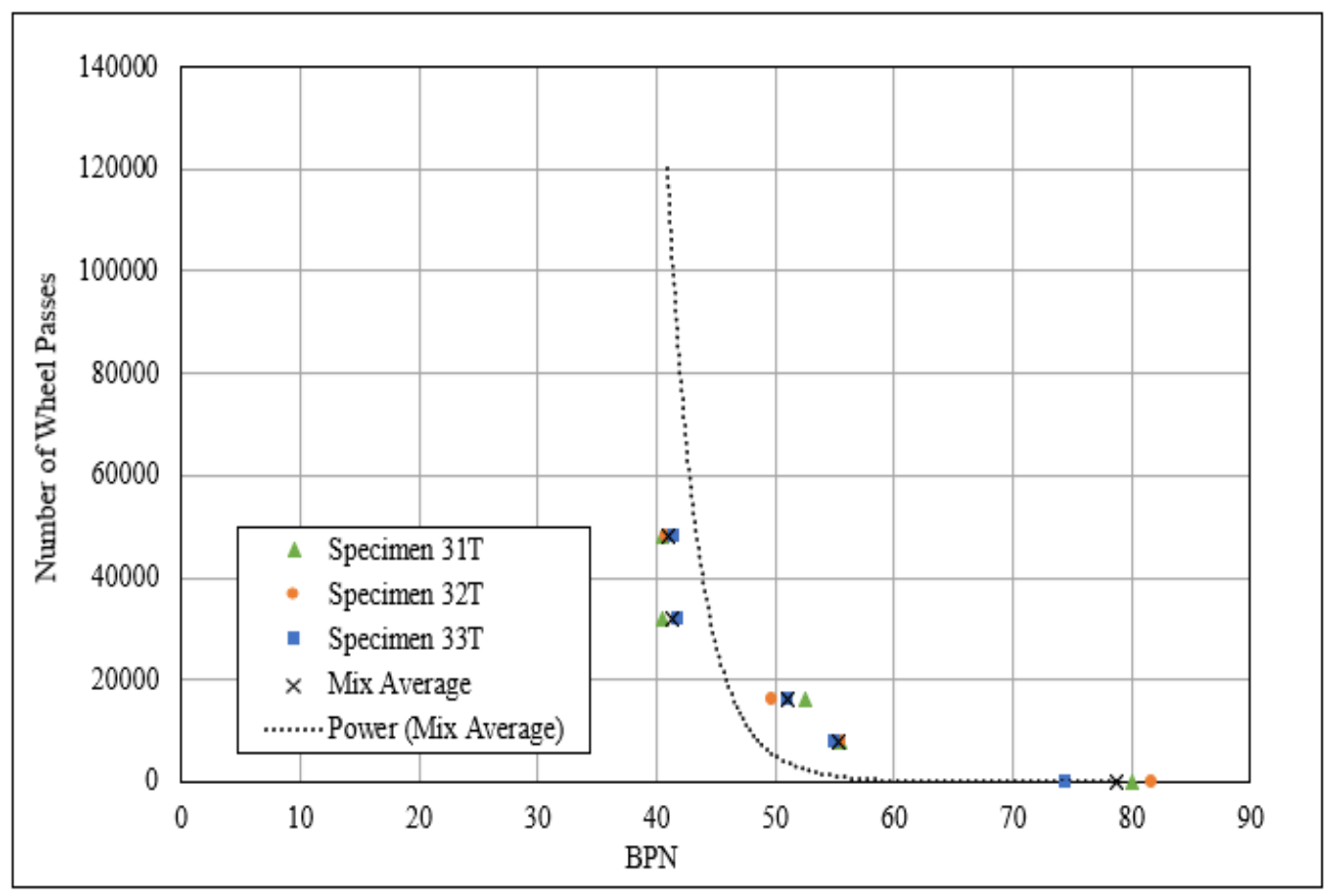

Figure 74: Trial 7 Prediction of Required Wheel Passes at BPN Limits for WVP W1-RAP Specimens (Top Surfaces) at 4\% VTM After 48,000 Wheel Passes 


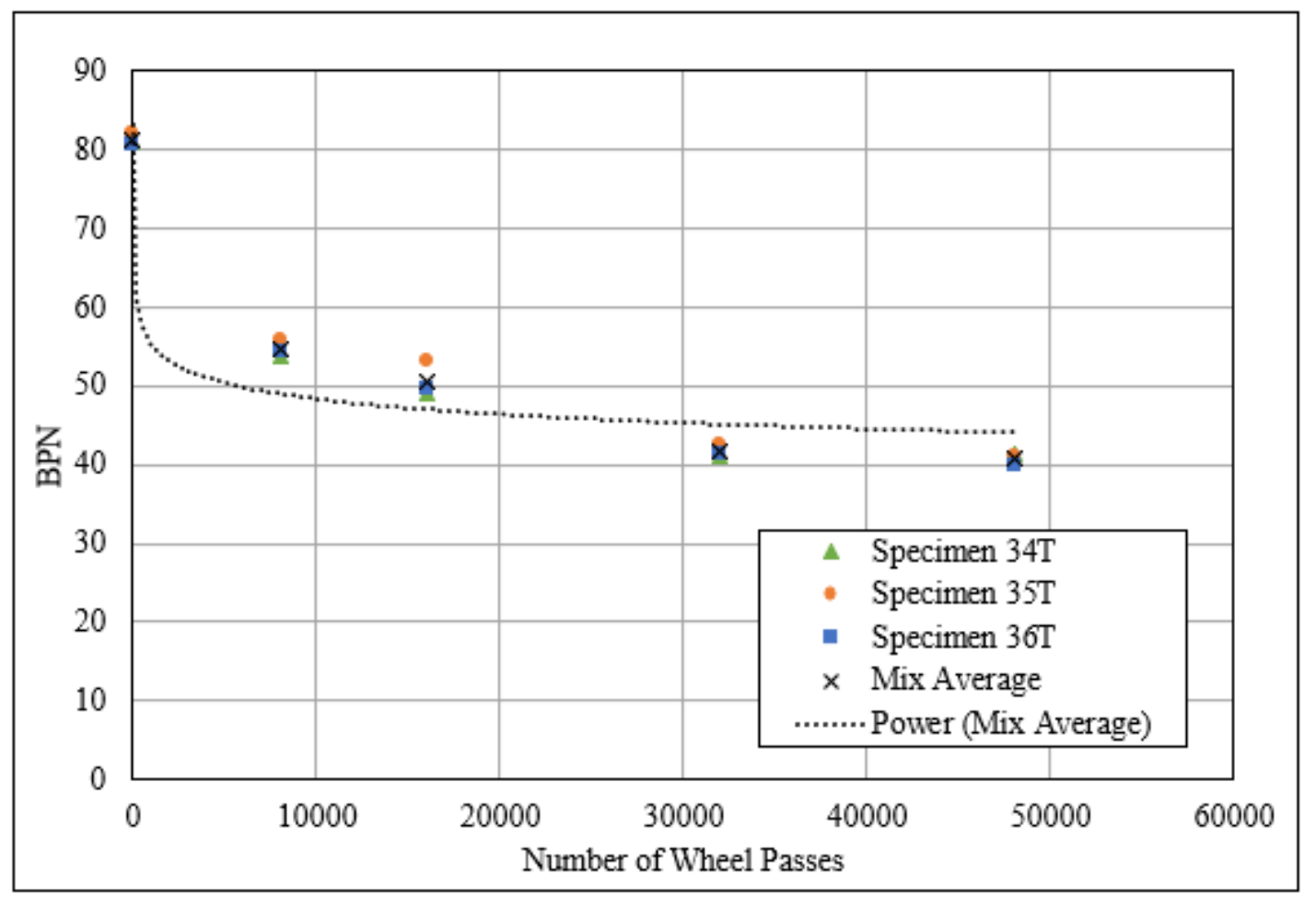

Figure 75: Trial 7 Average BPN Trend for WVP W1-RAP Specimens (Top Surfaces) at 8\% VTM After 48,000 Wheel Passes

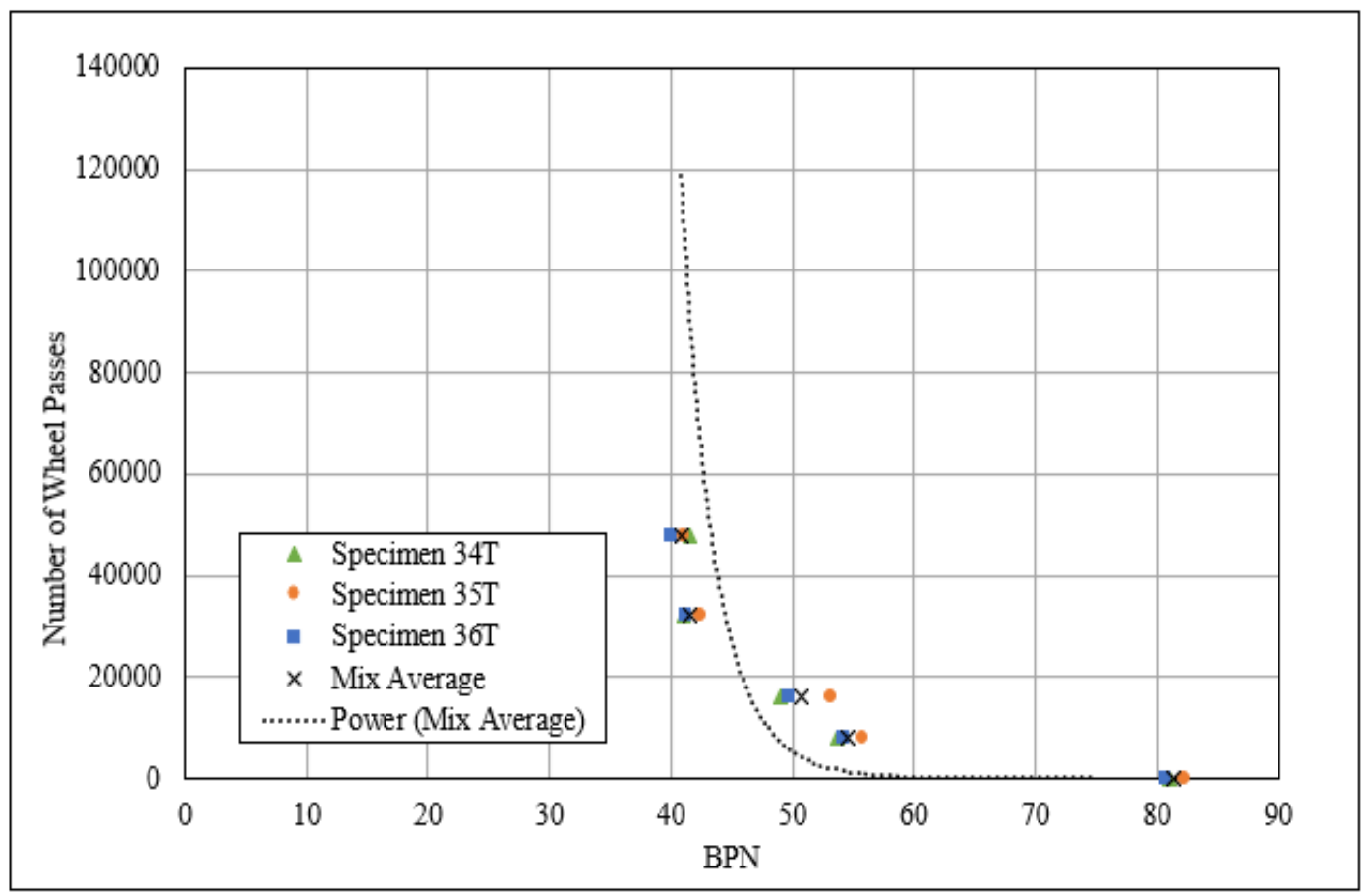

Figure 76: Trial 7 Prediction of Required Wheel Passes at BPN Limits for WVP W1-RAP Specimens (Top Surfaces) at 8\% VTM After 48,000 Wheel Passes 


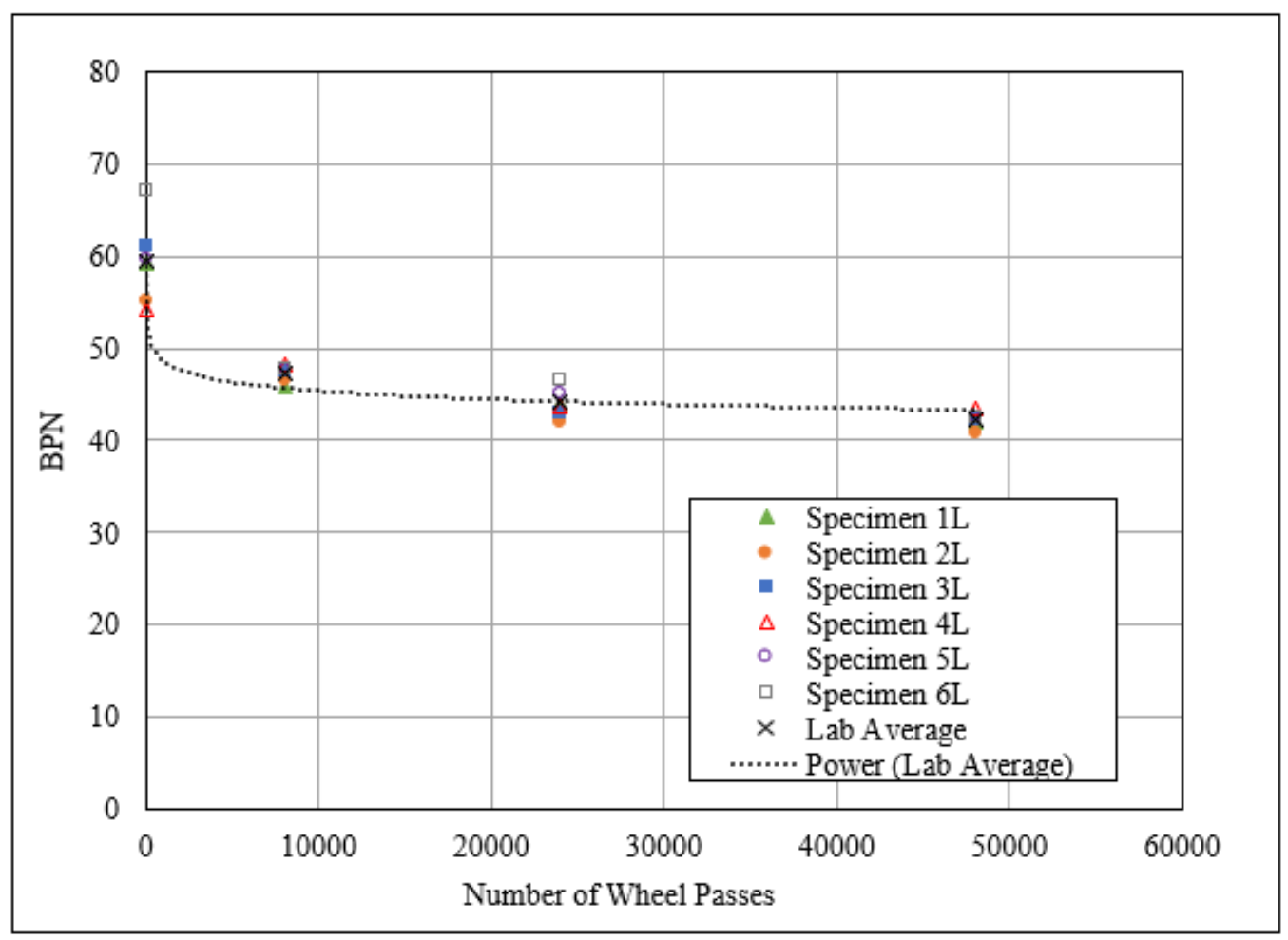

Figure 77: Trial 8 Average BPN Trend for JFA 12.5mm SR Laboratory Compacted Specimens After 48,000 Wheel Passes

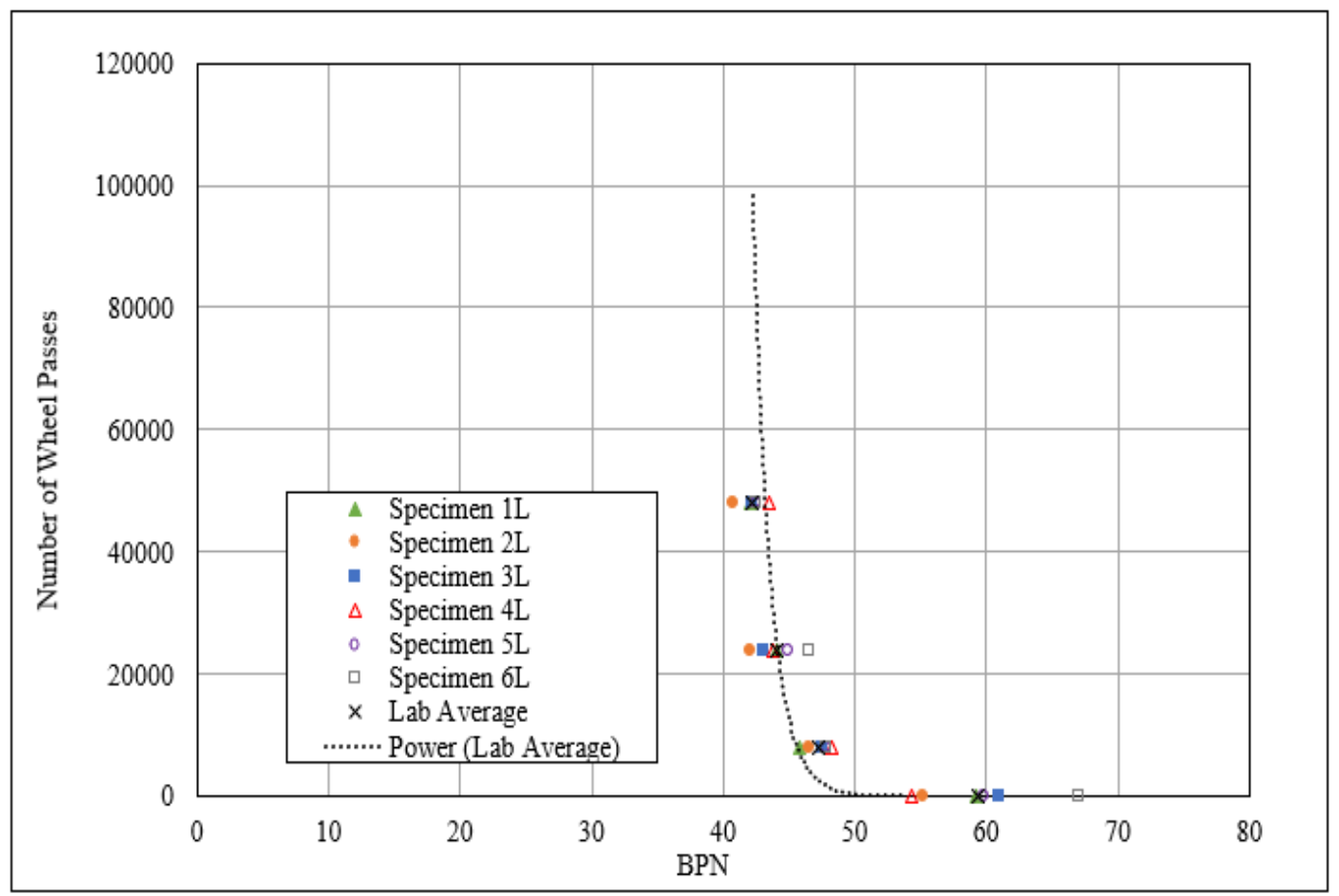

Figure 78: Trial 8 Prediction of Required Wheel Passes at BPN Limits for JFA 12.5mm SR Laboratory Compacted Specimens After 48,000 Wheel Passes 


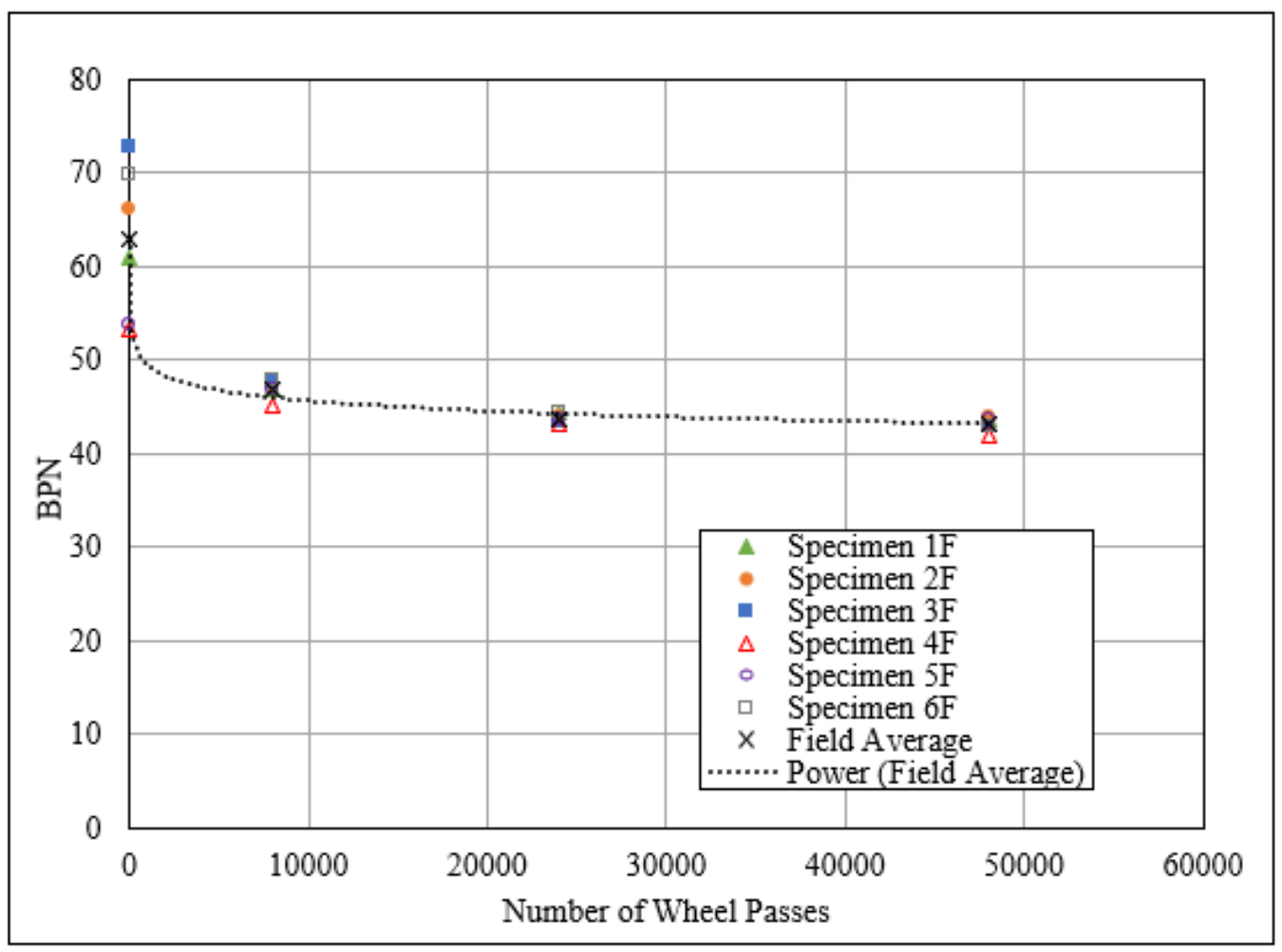

Figure 79: Trial 8 Average BPN Trends for JFA 12.5mm SR Field Core Specimens After 48,000 Wheel Passes

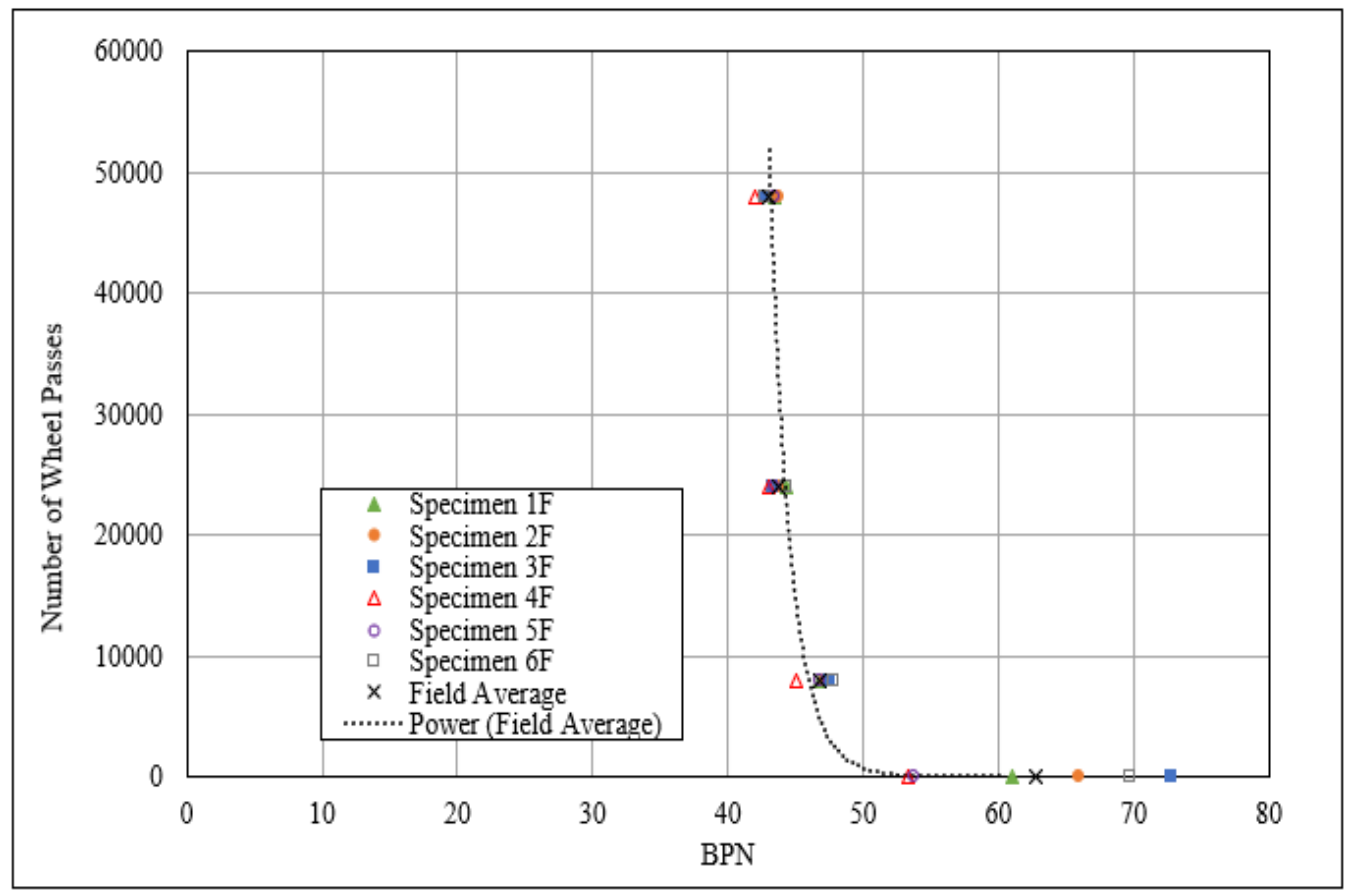

Figure 80: Trial 8 Prediction of Required Wheel Passes at BPN Limits for JFA 12.5mm SR Field Core Specimens After 48,000 Wheel Passes 


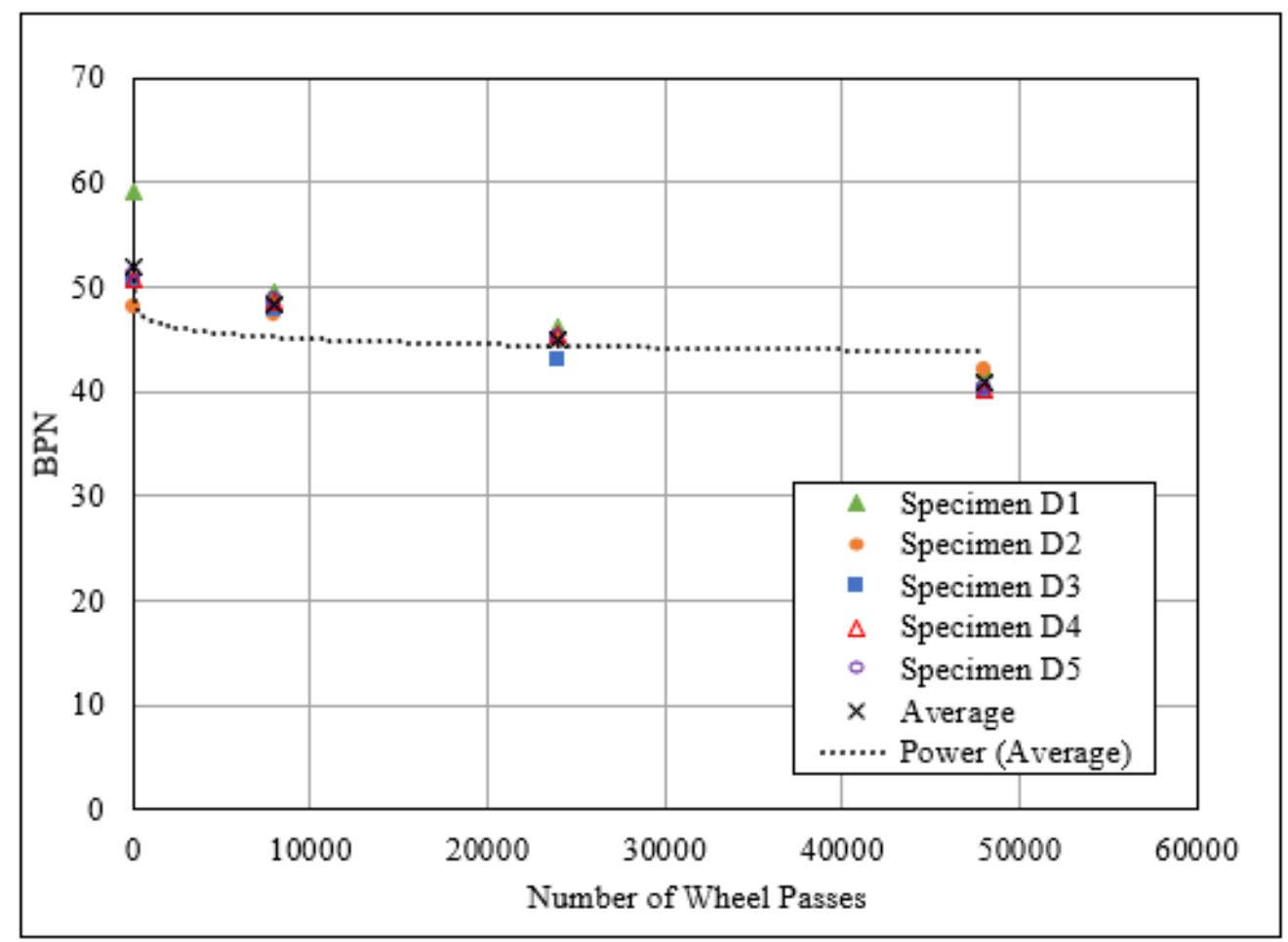

Figure 81:Trial 9 Average BPN Trends for JFA 12.5mm SR Field Core Specimens After 48,000 Wheel Passes

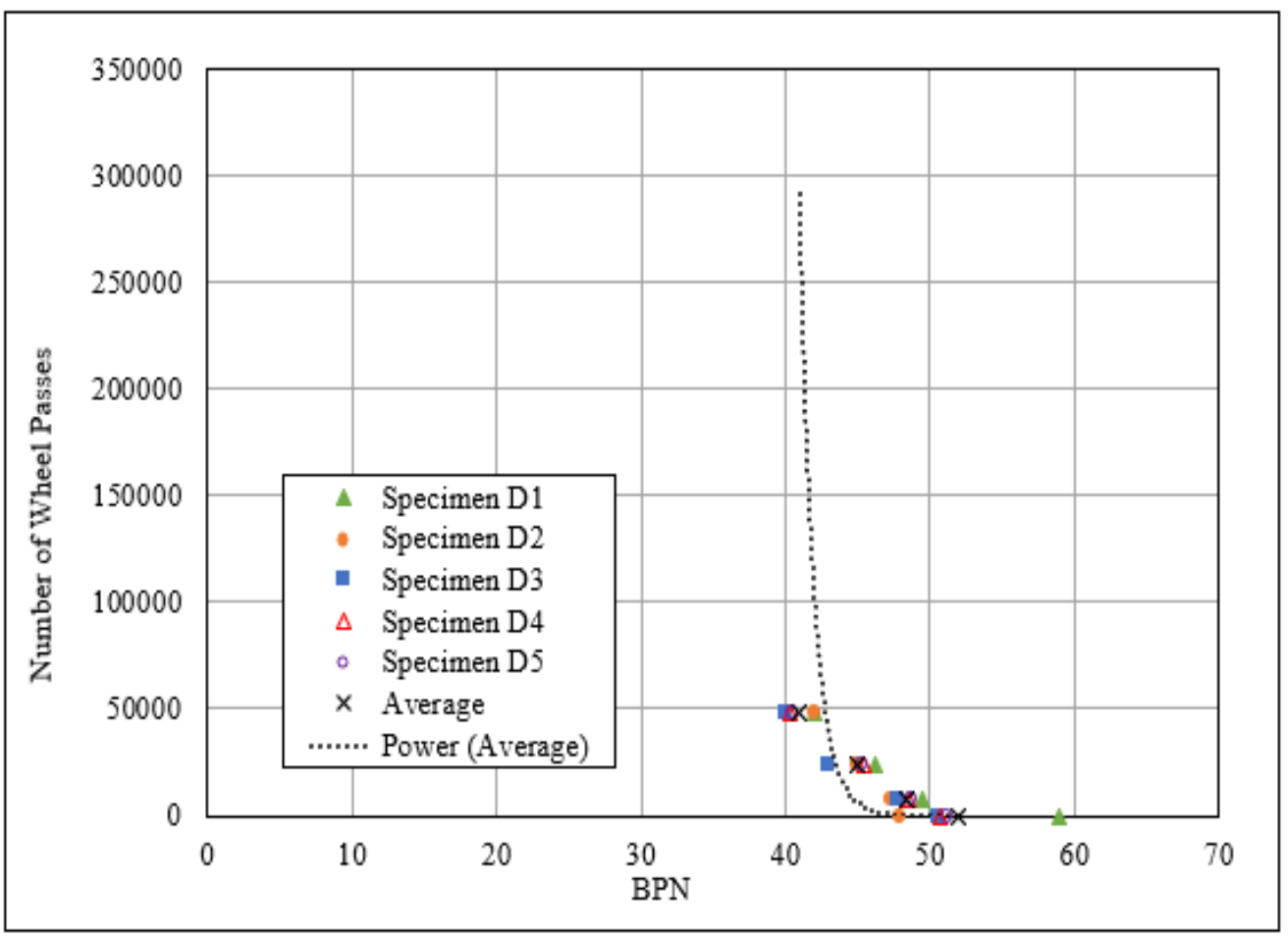

Figure 82: Trial 9 Prediction of Required Wheel Passes at BPN Limits for JFA 12.5mm SR Field Core Specimens After 48,000 Wheel Passes 


\section{Appendix F: Statistical Analysis Data and T-test Results}

\section{Toe Angles (B55A Tire Data)}

Table 55: Data and Excel Output for JFA 12.5mm SR and WVP W1-RAP Polished with Burris B55A Tires at Low and High Toe Angles

\begin{tabular}{|c|c|c|c|}
\hline & Mix & Sample & $\mathrm{BPN}_{48000}$ \\
\hline \multirow[t]{12}{*}{ Low Toe } & JFA 12.5 & $4 \mathrm{~T}$ & 48 \\
\hline & JFA 12.5 & $5 \mathrm{~T}$ & 45.75 \\
\hline & JFA 12.5 & $6 \mathrm{~T}$ & 47.5 \\
\hline & JFA 12.5 & $1 \mathrm{~T}$ & 51.5 \\
\hline & JFA 12.5 & $2 \mathrm{~T}$ & 47.75 \\
\hline & JFA 12.5 & $3 \mathrm{~T}$ & 49.25 \\
\hline & WVP W1 & $7 \mathrm{~T}$ & 51.25 \\
\hline & WVP W1 & $8 \mathrm{~T}$ & 51.75 \\
\hline & WVP W1 & $9 \mathrm{~T}$ & 49.25 \\
\hline & WVP W1 & $10 \mathrm{~T}$ & 51.75 \\
\hline & WVP W1 & $11 \mathrm{~T}$ & 50.25 \\
\hline & WVP W1 & $12 \mathrm{~T}$ & 55.75 \\
\hline \multirow[t]{12}{*}{ High Toe } & JFA 12.5 & $4 \mathrm{~B}$ & 44.75 \\
\hline & JFA 12.5 & $5 \mathrm{~B}$ & 47.75 \\
\hline & JFA 12.5 & $6 \mathrm{~B}$ & 47.75 \\
\hline & JFA 12.5 & 1B & 48.5 \\
\hline & JFA 12.5 & $2 \mathrm{~B}$ & 48 \\
\hline & JFA 12.5 & $3 \mathrm{~B}$ & 49 \\
\hline & WVP W1 & $7 \mathrm{~B}$ & 49.25 \\
\hline & WVP W1 & $8 \mathrm{~B}$ & 48.75 \\
\hline & WVP W1 & $9 \mathrm{~B}$ & 49 \\
\hline & WVP W1 & $10 \mathrm{~B}$ & 49.25 \\
\hline & WVP W1 & $11 \mathrm{~B}$ & 50 \\
\hline & WVP W1 & $12 \mathrm{~B}$ & 49.75 \\
\hline
\end{tabular}

\begin{tabular}{|l|r|r|}
\hline t-Test: Two-Sample Assuming Equal Variances \\
\hline & Variable 1 & Variable 2 \\
\hline Mean & 49.979167 & 48.479167 \\
\hline Variance & 7.0506629 & 1.9029356 \\
\hline Observations & 12 & 12 \\
\hline Pooled Variance & 4.4767992 & \\
\hline Hypothesized Mean Difference & 0 & \\
\hline ff & 22 & \\
\hline$t$ Stat & 1.7365331 & \\
\hline P(T<=t) one-tail & 0.0482271 & \\
\hline$t$ Critical one-tail & 1.7171444 & \\
\hline P(T<=t) two-tail & $\mathbf{0 . 0 9 6 4 5 4 1}$ & \\
\hline$t$ Critical two-tail & 2.0738731 & \\
\hline
\end{tabular}




\section{VTM (Hoosier R80 Tire Data)}

Table 56: Data and Excel Output for All Mixtures Polished with Hoosier R80 Tires at 4\% and $8 \%$ VTM

\begin{tabular}{|c|c|c|c|}
\hline & Mix & Sample & $\mathrm{BPN}_{48000}$ \\
\hline \multirow[t]{24}{*}{$4 \%$ VTM } & Greer W1 & $16 \mathrm{~B}$ & 43 \\
\hline & Greer W1 & $17 \mathrm{~B}$ & 42.75 \\
\hline & Greer W1 & $18 \mathrm{~B}$ & 43 \\
\hline & WVP 12.5 & $18 \mathrm{~B}$ & 45.5 \\
\hline & WVP 12.5 & $20 B$ & 47.5 \\
\hline & WVP 12.5 & $21 \mathrm{~B}$ & 44.25 \\
\hline & JFA 12.5 & $25 \mathrm{~B}$ & 47.5 \\
\hline & JFA 12.5 & $26 \mathrm{~B}$ & 47.25 \\
\hline & JFA 12.5 & $27 \mathrm{~B}$ & 48.75 \\
\hline & WVP W1 & $31 B$ & 50.75 \\
\hline & WVP W1 & $32 \mathrm{~B}$ & 48.75 \\
\hline & WVP W1 & $33 B$ & 50.5 \\
\hline & Greer W1 & $16 \mathrm{~T}$ & 44.5 \\
\hline & Greer W1 & $17 \mathrm{~T}$ & 43.25 \\
\hline & Greer W1 & $18 \mathrm{~T}$ & 42.75 \\
\hline & WVP 12.5 & $18 \mathrm{~T}$ & 46.25 \\
\hline & WVP 12.5 & $20 \mathrm{~T}$ & 45.75 \\
\hline & WVP 12.5 & $21 \mathrm{~T}$ & 47.75 \\
\hline & JFA 12.5 & $25 \mathrm{~T}$ & 40.25 \\
\hline & JFA 12.5 & $26 \mathrm{~T}$ & 40 \\
\hline & JFA 12.5 & $27 \mathrm{~T}$ & 41 \\
\hline & WVP W1 & $31 \mathrm{~T}$ & 40.5 \\
\hline & WVP W1 & $32 \mathrm{~T}$ & 40.75 \\
\hline & WVP W1 & $33 \mathrm{~T}$ & 41.5 \\
\hline \multirow[t]{24}{*}{$8 \%$ VTM } & Greer W1 & $13 B$ & 43.75 \\
\hline & Greer W1 & $14 B$ & 42.5 \\
\hline & Greer W1 & $15 B$ & 43.75 \\
\hline & WVP 12.5 & $22 \mathrm{~B}$ & 43.75 \\
\hline & WVP 12.5 & $23 B$ & 43.5 \\
\hline & WVP 12.5 & $24 B$ & 45.75 \\
\hline & JFA 12.5 & $28 B$ & 49.75 \\
\hline & JFA 12.5 & $29 B$ & 49 \\
\hline & JFA 12.5 & $30 \mathrm{~B}$ & 49.25 \\
\hline & WVP W1 & $34 B$ & 50.75 \\
\hline & WVP W1 & $35 \mathrm{~B}$ & 50.25 \\
\hline & WVP W1 & $36 \mathrm{~B}$ & 48.75 \\
\hline & Greer W1 & $13 \mathrm{~T}$ & 43 \\
\hline & Greer W1 & $14 \mathrm{~T}$ & 43.5 \\
\hline & Greer W1 & $15 \mathrm{~T}$ & 44.75 \\
\hline & WVP 12.5 & $22 \mathrm{~T}$ & 47.5 \\
\hline & WVP 12.5 & $23 \mathrm{~T}$ & 46.25 \\
\hline & WVP 12.5 & $24 \mathrm{~T}$ & 47 \\
\hline & JFA 12.5 & $28 \mathrm{~T}$ & 40.5 \\
\hline & JFA 12.5 & $29 \mathrm{~T}$ & 41.75 \\
\hline & JFA 12.5 & $30 \mathrm{~T}$ & 40.5 \\
\hline & WVP W1 & $34 \mathrm{~T}$ & 41.5 \\
\hline & WVP W1 & $35 \mathrm{~T}$ & 41 \\
\hline & WVP W1 & $36 \mathrm{~T}$ & 40 \\
\hline
\end{tabular}

\begin{tabular}{|c|c|c|}
\hline \multirow[t]{2}{*}{\begin{tabular}{|l} 
t-Test: Two-Sample Assuming Equal Variances \\
\end{tabular}} & & \\
\hline & \begin{tabular}{|l|} 
Variable 1 \\
\end{tabular} & Variable 2 \\
\hline Mean & 44.739583 & 44.916667 \\
\hline Variance & 11.018909 & 11.623188 \\
\hline Observations & 24 & 24 \\
\hline Pooled Variance & 11.321048 & \\
\hline Hypothesized Mean Difference & 0 & \\
\hline df & 46 & \\
\hline t Stat & -0.1823161 & \\
\hline $\mathrm{P}(\mathrm{T}<=\mathrm{t})$ one-tail & 0.4280679 & \\
\hline t Critical one-tail & 1.6786604 & \\
\hline $\mathrm{P}(\mathrm{T}<=\mathrm{t})$ two-tail & 0.8561358 & \\
\hline t Critical two-tail & 2.0128956 & \\
\hline
\end{tabular}




\section{Toe Angles (Hoosier R80 Tire Data)}

Table 57: Data and Excel Output for All Mixtures Polished with Hoosier R80 Tires at Low and High Toe Angles

\begin{tabular}{|c|c|c|c|}
\hline & Mix & Sample & $\mathrm{BPN}_{48000}$ \\
\hline \multirow[t]{24}{*}{ Low Toe } & WVP 12.5 & $19 \mathrm{~B}$ & 45.5 \\
\hline & WVP 12.5 & $20 \mathrm{~B}$ & 47.5 \\
\hline & WVP 12.5 & $21 \mathrm{~B}$ & 44.25 \\
\hline & WVP 12.5 & $22 \mathrm{~B}$ & 43.75 \\
\hline & WVP 12.5 & $23 B$ & 43.5 \\
\hline & WVP 12.5 & $24 B$ & 45.75 \\
\hline & Greer W1 & $16 \mathrm{~B}$ & 43 \\
\hline & Greer W1 & $17 \mathrm{~B}$ & 42.75 \\
\hline & Greer W1 & $18 \mathrm{~B}$ & 43 \\
\hline & Greer W1 & $13 B$ & 43.75 \\
\hline & Greer W1 & $14 \mathrm{~B}$ & 42.5 \\
\hline & Greer W1 & $15 \mathrm{~B}$ & 43.75 \\
\hline & JFA 12.5 & $25 \mathrm{~B}$ & 47.5 \\
\hline & JFA 12.5 & $26 \mathrm{~B}$ & 47.25 \\
\hline & JFA 12.5 & $27 \mathrm{~B}$ & 48.75 \\
\hline & JFA 12.5 & $28 \mathrm{~B}$ & 49.75 \\
\hline & JFA 12.5 & $29 \mathrm{~B}$ & 49 \\
\hline & JFA 12.5 & $30 \mathrm{~B}$ & 49.25 \\
\hline & WVP W1 & $31 \mathrm{~B}$ & 50.75 \\
\hline & WVP W1 & $32 \mathrm{~B}$ & 48.75 \\
\hline & WVP W1 & $33 B$ & 50.5 \\
\hline & WVP W1 & $34 \mathrm{~B}$ & 50.75 \\
\hline & WVP Wl & $35 \mathrm{~B}$ & 50.25 \\
\hline & WVP W1 & $36 \mathrm{~B}$ & 48.75 \\
\hline \multirow[t]{24}{*}{ High Toe } & WVP 12.5 & $19 \mathrm{~T}$ & 46.25 \\
\hline & WVP 12.5 & $20 \mathrm{~T}$ & 45.75 \\
\hline & WVP 12.5 & $21 \mathrm{~T}$ & 47.75 \\
\hline & WVP 12.5 & $22 \mathrm{~T}$ & 47.5 \\
\hline & WVP 12.5 & $23 \mathrm{~T}$ & 46.25 \\
\hline & WVP 12.5 & $24 \mathrm{~T}$ & 47 \\
\hline & Greer W1 & $16 \mathrm{~T}$ & 44.5 \\
\hline & Greer W1 & $17 \mathrm{~T}$ & 43.25 \\
\hline & Greer W1 & $18 \mathrm{~T}$ & 42.75 \\
\hline & Greer W1 & $13 \mathrm{~T}$ & 43 \\
\hline & Greer W1 & $14 \mathrm{~T}$ & 43.5 \\
\hline & Greer W1 & $15 \mathrm{~T}$ & 44.75 \\
\hline & JFA 12.5 & $25 \mathrm{~T}$ & 40.25 \\
\hline & JFA 12.5 & $26 \mathrm{~T}$ & 40 \\
\hline & JFA 12.5 & $27 \mathrm{~T}$ & 41 \\
\hline & JFA 12.5 & $28 \mathrm{~T}$ & 40.5 \\
\hline & JFA 12.5 & $29 \mathrm{~T}$ & 41.75 \\
\hline & JFA 12.5 & $30 \mathrm{~T}$ & 40.5 \\
\hline & WVP W1 & $31 \mathrm{~T}$ & 40.5 \\
\hline & WVP Wl & $32 \mathrm{~T}$ & 40.75 \\
\hline & WVP W1 & $33 \mathrm{~T}$ & 41.5 \\
\hline & WVP W1 & $34 \mathrm{~T}$ & 41.5 \\
\hline & WVP W1 & $35 \mathrm{~T}$ & 41 \\
\hline & WVP W1 & $36 \mathrm{~T}$ & 40 \\
\hline
\end{tabular}

\begin{tabular}{|l|r|r|}
\hline$t-T e s t:$ Two-Sample Assuming Equal Variances & & \\
\hline & Variable 1 & Variable 2 \\
\hline Mean & 46.677083 & 42.979167 \\
\hline Variance & 8.7145607 & 6.8093297 \\
\hline Observations & 24 & 24 \\
\hline Pooled Variance & 7.7619452 & \\
\hline Hypothesized Mean Difference & 0 & \\
\hline df & 46 & \\
\hline$t$ Stat & 4.5979311 & \\
\hline$P(T<=t)$ one-tail & $1.671 E-05$ & \\
\hline$t$ Critical one-tail & 1.6786604 & \\
\hline$P(T<=t)$ two-tail & $\mathbf{3 . 3 4 2 E}-05$ & \\
\hline$t$ Critical two-tail & 2.0128956 & \\
\hline
\end{tabular}




\section{NMAS (Hoosier R80 Tire Data)}

Table 58: Data and Excel Output for All Mixtures Polished with Hoosier R80 Tires Comparing $9.5 \mathrm{~mm}$ and $12.5 \mathrm{~mm}$ NMAS

\begin{tabular}{|c|c|c|c|}
\hline & Mix & Sample & $\mathrm{BPN}_{48000}$ \\
\hline \multirow[t]{24}{*}{$9.5 \mathrm{~mm}$} & WVP W1 & $31 \mathrm{~B}$ & 50.75 \\
\hline & \begin{tabular}{|l|} 
WVP W1 \\
\end{tabular} & $32 \mathrm{~B}$ & 48.75 \\
\hline & WVP W1 & $33 B$ & 50.5 \\
\hline & WVP W1 & $34 B$ & 50.75 \\
\hline & WVP W1 & $35 \mathrm{~B}$ & 50.25 \\
\hline & WVP W1 & $36 \mathrm{~B}$ & 48.75 \\
\hline & WVP W1 & $31 \mathrm{~T}$ & 40.5 \\
\hline & WVP W1 & $32 \mathrm{~T}$ & 40.75 \\
\hline & \begin{tabular}{|l|} 
WVP W1 \\
\end{tabular} & $33 \mathrm{~T}$ & 41.5 \\
\hline & WVP W1 & $34 \mathrm{~T}$ & 41.5 \\
\hline & \begin{tabular}{|l} 
WVP W1 \\
\end{tabular} & $35 \mathrm{~T}$ & 41 \\
\hline & WVP W1 & $36 \mathrm{~T}$ & 40 \\
\hline & Greer W1 & $13 B$ & 43.75 \\
\hline & Greer W1 & $14 B$ & 42.5 \\
\hline & Greer W1 & $15 \mathrm{~B}$ & 43.75 \\
\hline & Greer W1 & $16 \mathrm{~B}$ & 43 \\
\hline & Greer W1 & $17 \mathrm{~B}$ & 42.75 \\
\hline & Greer W1 & $18 \mathrm{~B}$ & 43 \\
\hline & Greer W1 & $13 \mathrm{~T}$ & 43 \\
\hline & Greer W1 & $14 \mathrm{~T}$ & 43.5 \\
\hline & Greer W1 & $15 \mathrm{~T}$ & 44.75 \\
\hline & Greer W1 & $16 \mathrm{~T}$ & 44.5 \\
\hline & Greer W1 & $17 \mathrm{~T}$ & 43.25 \\
\hline & Greer W1 & $18 \mathrm{~T}$ & 42.75 \\
\hline \multirow[t]{24}{*}{\begin{tabular}{|l|}
$12.5 \mathrm{~mm}$ \\
\end{tabular}} & WVP 12.5 & $19 \mathrm{~B}$ & 45.5 \\
\hline & WVP 12.5 & $20 B$ & 47.5 \\
\hline & WVP 12.5 & $21 B$ & 44.25 \\
\hline & WVP 12.5 & $22 \mathrm{~B}$ & 43.75 \\
\hline & WVP 12.5 & $23 \mathrm{~B}$ & 43.5 \\
\hline & WVP 12.5 & $24 B$ & 45.75 \\
\hline & WVP 12.5 & $19 \mathrm{~T}$ & 46.25 \\
\hline & WVP 12.5 & $20 \mathrm{~T}$ & 45.75 \\
\hline & WVP 12.5 & $21 \mathrm{~T}$ & 47.75 \\
\hline & WVP 12.5 & $22 \mathrm{~T}$ & 47.5 \\
\hline & WVP 12.5 & $23 \mathrm{~T}$ & 46.25 \\
\hline & WVP 12.5 & $24 \mathrm{~T}$ & 47 \\
\hline & JFA 12.5 & $25 \mathrm{~B}$ & 47.5 \\
\hline & JFA 12.5 & $26 \mathrm{~B}$ & 47.25 \\
\hline & JFA 12.5 & $27 \mathrm{~B}$ & 48.75 \\
\hline & JFA 12.5 & $25 \mathrm{~T}$ & 40.25 \\
\hline & JFA 12.5 & $26 \mathrm{~T}$ & 40 \\
\hline & JFA 12.5 & $27 \mathrm{~T}$ & 41 \\
\hline & JFA 12.5 & $28 B$ & 49.75 \\
\hline & JFA 12.5 & $29 \mathrm{~B}$ & 49 \\
\hline & JFA 12.5 & $30 B$ & 49.25 \\
\hline & JFA 12.5 & $28 \mathrm{~T}$ & 40.5 \\
\hline & JFA 12.5 & $29 \mathrm{~T}$ & 41.75 \\
\hline & JFA 12.5 & $30 \mathrm{~T}$ & 40.5 \\
\hline
\end{tabular}

\begin{tabular}{|l|r|r|}
\hline$t$-Test: Two-Sample Assuming Equal Variances & & \\
\hline & Variable 1 & Variable 2 \\
\hline Mean & 44.395833 & 45.26042 \\
\hline Variance & 12.358243 & 9.910213 \\
\hline Observations & 24 & 24 \\
\hline Pooled Variance & 11.134228 & \\
\hline Hypothesized Mean Difference & 0 & \\
\hline df & 46 & \\
\hline $\mathrm{t}$ Stat & -0.8975681 & \\
\hline $\mathrm{P}(\mathrm{T}<=\mathrm{t})$ one-tail & 0.1870449 & \\
\hline $\mathrm{t}$ Critical one-tail & 1.6786604 & \\
\hline $\mathrm{P}(\mathrm{T}<=\mathrm{t})$ two-tail & 0.3740897 & \\
\hline $\mathrm{t}$ Critical two-tail & 2.0128956 & \\
\hline
\end{tabular}




\section{Contractor (Hoosier R80 Tire Data)}

Table 59: Data and Excel Output for 12.5mm Mixtures Polished with Hoosier R80 Tires Comparing JFA and WVP Contractors

\begin{tabular}{|c|c|c|c|}
\hline & Mix & Sample & BPN $_{48000}$ \\
\hline JFA & JFA 12.5 & 25B & 47.5 \\
\hline & JFA 12.5 & 26B & 47.25 \\
\hline & JFA 12.5 & $27 \mathrm{~B}$ & 48.75 \\
\hline & JFA 12.5 & $25 \mathrm{~T}$ & 40.25 \\
\hline & JFA 12.5 & $26 \mathrm{~T}$ & 40 \\
\hline & JFA 12.5 & $27 \mathrm{~T}$ & 41 \\
\hline & JFA 12.5 & 28B & 49.75 \\
\hline & JFA 12.5 & $29 \mathrm{~B}$ & 49 \\
\hline & JFA 12.5 & $30 \mathrm{~B}$ & 49.25 \\
\hline & JFA 12.5 & $28 \mathrm{~T}$ & 40.5 \\
\hline & JFA 12.5 & $29 \mathrm{~T}$ & 41.75 \\
\hline & JFA 12.5 & $30 \mathrm{~T}$ & 40.5 \\
\hline WVP & WVP 12.5 & $19 \mathrm{~B}$ & 45.5 \\
\hline & WVP 12.5 & $20 \mathrm{~B}$ & 47.5 \\
\hline & WVP 12.5 & $21 \mathrm{~B}$ & 44.25 \\
\hline & WVP 12.5 & $19 \mathrm{~T}$ & 46.25 \\
\hline & WVP 12.5 & $20 \mathrm{~T}$ & 45.75 \\
\hline & WVP 12.5 & $21 \mathrm{~T}$ & 47.75 \\
\hline & WVP 12.5 & $22 \mathrm{~B}$ & 43.75 \\
\hline & WVP 12.5 & $23 \mathrm{~B}$ & 43.5 \\
\hline WVP 12.5 & $24 \mathrm{~B}$ & 45.75 \\
\hline & WVP 12.5 & $22 \mathrm{~T}$ & 47.5 \\
\hline WVP 12.5 & $23 \mathrm{~T}$ & 46.25 \\
\hline & WVP 12.5 & $24 \mathrm{~T}$ & 47 \\
\hline & & \\
\hline
\end{tabular}

\begin{tabular}{|l|r|r|}
\hline t-Test: Two-Sample Assuming Equal Variances & & \\
\hline & Variable 1 & Variable 2 \\
\hline Mean & 44.625 & 45.89583 \\
\hline Variance & 17.721591 & 2.118845 \\
\hline Observations & 12 & 12 \\
\hline Pooled Variance & 9.9202178 & \\
\hline Hypothesized Mean Difference & 0 & \\
\hline df & 22 & \\
\hline $\mathrm{t}$ Stat & -0.9883337 & \\
\hline $\mathrm{P}(\mathrm{T}<=\mathrm{t})$ one-tail & 0.1668677 & \\
\hline $\mathrm{t}$ Critical one-tail & 1.7171444 & \\
\hline $\mathrm{P}(\mathrm{T}<=\mathrm{t})$ two-tail & 0.3337353 & \\
\hline $\mathrm{t}$ Critical two-tail & 2.0738731 & \\
\hline
\end{tabular}


Table 60: Data and Excel Output for 9.5mm Mixtures Polished with Hoosier R80 Tires Comparing Greer and WVP Contractors

\begin{tabular}{|c|c|c|c|}
\hline & Mix & Sample & $\mathrm{BPN}_{48000}$ \\
\hline \multirow[t]{12}{*}{ Greer } & Greer W1 & $13 B$ & 43.75 \\
\hline & Greer W1 & $14 B$ & 42.5 \\
\hline & Greer W1 & $15 \mathrm{~B}$ & 43.75 \\
\hline & Greer W1 & $16 \mathrm{~B}$ & 43 \\
\hline & Greer W1 & $17 \mathrm{~B}$ & 42.75 \\
\hline & Greer W1 & $18 B$ & 43 \\
\hline & Greer Wl & $13 \mathrm{~T}$ & 43 \\
\hline & Greer W1 & $14 \mathrm{~T}$ & 43.5 \\
\hline & Greer W1 & $15 \mathrm{~T}$ & 44.75 \\
\hline & Greer W1 & $16 \mathrm{~T}$ & 44.5 \\
\hline & Greer W1 & $17 \mathrm{~T}$ & 43.25 \\
\hline & Greer W1 & $18 \mathrm{~T}$ & 42.75 \\
\hline \multirow[t]{12}{*}{ WVP } & WVP Wl & $31 B$ & 50.75 \\
\hline & WVP W1 & $32 \mathrm{~B}$ & 48.75 \\
\hline & WVP W1 & $33 B$ & 50.5 \\
\hline & WVP W1 & $34 B$ & 50.75 \\
\hline & WVP W1 & $35 \mathrm{~B}$ & 50.25 \\
\hline & WVP W1 & $36 \mathrm{~B}$ & 48.75 \\
\hline & WVP W1 & $31 \mathrm{~T}$ & 40.5 \\
\hline & WVP W1 & $32 \mathrm{~T}$ & 40.75 \\
\hline & WVP W1 & $33 \mathrm{~T}$ & 41.5 \\
\hline & WVP W1 & $34 \mathrm{~T}$ & 41.5 \\
\hline & WVP W1 & $35 \mathrm{~T}$ & 41 \\
\hline & WVP W1 & $36 \mathrm{~T}$ & 40 \\
\hline
\end{tabular}

\begin{tabular}{|c|c|c|}
\hline t-Test: Two-Sample Assuming Equal Variances & & \\
\hline & Variable 1 & Variable 2 \\
\hline Mean & 43.375 & 45.41667 \\
\hline Variance & 0.4943182 & 23.07197 \\
\hline Observations & 12 & 12 \\
\hline Pooled Variance & 11.783144 & \\
\hline Hypothesized Mean Difference & 0 & \\
\hline df & 22 & \\
\hline t Stat & -1.4569004 & \\
\hline $\mathrm{P}(\mathrm{T}<=\mathrm{t})$ one-tail & 0.0796349 & \\
\hline t Critical one-tail & 1.7171444 & \\
\hline $\mathrm{P}(\mathrm{T}<=\mathrm{t}) \mathrm{two}-\mathrm{tail}$ & 0.1592698 & \\
\hline t Critical two-tail & 2.0738731 & \\
\hline
\end{tabular}




\section{Environment (Laboratory vs. Field)}

Table 61: Data and Excel Output Comparing Initial BPN Measurements for JFA 12.5mm SR Laboratory Compacted and Corresponding Field Core Specimens Polished with Hoosier R80 Tires

\begin{tabular}{|c|c|c|}
\hline & Sample & BPN $_{0}$ \\
\hline \multirow{4}{*}{ JFA 12.5mm SR } & $1 \mathrm{~L}$ & 59.3 \\
\cline { 2 - 3 } $\begin{array}{c}\text { Laboratory } \\
\text { Compacted }\end{array}$ & $2 \mathrm{~L}$ & 55.3 \\
\cline { 2 - 3 } & $3 \mathrm{~L}$ & 61.0 \\
\cline { 2 - 3 } & $4 \mathrm{~A}$ & 54.3 \\
\cline { 2 - 3 } & $5 \mathrm{~L}$ & 59.8 \\
\cline { 2 - 3 } & $6 \mathrm{~L}$ & 67.0 \\
\hline \multirow{4}{*}{ JFA 12.5mm SR } & $1 \mathrm{~F}$ & 61.0 \\
\cline { 2 - 3 } & $2 \mathrm{~F}$ & 66.0 \\
\cline { 2 - 3 } I-79 Field Cores & $3 \mathrm{~F}$ & 72.8 \\
\cline { 2 - 3 } & $4 \mathrm{~F}$ & 53.3 \\
\cline { 2 - 3 } & $5 \mathrm{~F}$ & 53.8 \\
\cline { 2 - 3 } & $6 \mathrm{~F}$ & 69.8 \\
\hline
\end{tabular}

\begin{tabular}{|l|r|r|}
\hline$t$-Test: Two-Sample Assuming Equal Variances & \multicolumn{1}{|c|}{} \\
\hline & Variable 1 & Variable 2 \\
\hline Mean & 59.41666667 & 62.75 \\
\hline Variance & 20.84166667 & 66.775 \\
\hline Observations & 6 & 6 \\
\hline Pooled Variance & 03.80833333 & \\
\hline Hypothesized Mean Difference & 0 & \\
\hline df & 10 & \\
\hline$t$ Stat & -0.87229023 & \\
\hline $\mathrm{P}(\mathrm{T}<=\mathrm{t})$ one-tail & 0.201753992 & \\
\hline $\mathrm{t}$ Critical one-tail & 1.812461123 & \\
\hline $\mathrm{P}(\mathrm{T}<-\mathrm{t})$ two-tail & $\mathbf{0 . 4 0 3 5 0 8}$ & \\
\hline $\mathrm{t}$ Critical two-tail & 2.228138852 & \\
\hline
\end{tabular}

Table 62: Data and Excel Output Comparing BPN Measurements After Polishing 48,000 Wheel Passes for JFA $12.5 \mathrm{~mm}$ SR Laboratory Compacted and Corresponding Field Core Specimens Polished with Hoosier R80 Tires

\begin{tabular}{|c|c|c|}
\hline & Sample & BPN $_{48000}$ \\
\hline \multirow{4}{*}{ JFA 12.5mm SR } & $1 \mathrm{~L}$ & 42 \\
\cline { 2 - 3 } Laboratory & $2 \mathrm{~L}$ & 40.8 \\
\cline { 2 - 3 } Compacted & $3 \mathrm{~L}$ & 42.3 \\
\cline { 2 - 3 } & $4 \mathrm{~A}$ & 43.5 \\
\cline { 2 - 3 } & $5 \mathrm{~L}$ & 42.5 \\
\cline { 2 - 3 } & $6 \mathrm{~L}$ & 42.5 \\
\hline \multirow{4}{*}{ JFA 12.5mm SR } & $1 \mathrm{~F}$ & 43.5 \\
\cline { 2 - 3 } & $2 \mathrm{~F}$ & 43.8 \\
\cline { 2 - 3 } & $3 \mathrm{~F}$ & 42.8 \\
\cline { 2 - 3 } I-79 Field Cores & $4 \mathrm{~F}$ & 42.0 \\
\cline { 2 - 3 } & $5 \mathrm{~F}$ & 43.5 \\
\cline { 2 - 3 } & $6 \mathrm{~F}$ & 42.8 \\
\hline
\end{tabular}

\begin{tabular}{|l|r|r|}
\hline t-Test: Two-Sample Assuming Equal Variances & \multicolumn{1}{|c|}{} \\
\hline & Variable 1 & Variable 2 \\
\hline Mean & 42.25 & 43.0416667 \\
\hline Variance & 0.8 & 0.43541667 \\
\hline Observations & 6 & 6 \\
\hline Pooled Variance & 0 & \\
\hline Hypothesized Mean Difference & 10 & \\
\hline df & 0.617708333 & \\
\hline$t$ Stat & -1.74466182 & \\
\hline$P(T<=t)$ one-tail & 0.055820236 & \\
\hline$t$ Critical one-tail & 1.812461123 & \\
\hline$P(T<-t)$ two-tail & $\mathbf{0 . 1 1 1 6 4 0 5}$ & \\
\hline$t$ Critical two-tail & 2.228138852 & \\
\hline
\end{tabular}


Table 63: Data and Excel Output for JFA 12.5mm SR Field Core Specimens and Corresponding Average Field Measurements

\begin{tabular}{|c|c|c|}
\hline & Sample & BPN \\
\hline \multirow{4}{*}{ *Field Cores } & D1 & 59 \\
\cline { 2 - 3 } & D2 & 48 \\
\cline { 2 - 3 } & D3 & 50.5 \\
\cline { 2 - 3 } & D4 & 50.75 \\
\cline { 2 - 3 } & D5 & 51.25 \\
\hline \multirow{4}{*}{ **Avg. Field } & D1 & 74.5 \\
\cline { 2 - 3 } Measurements & D2 & 69.9 \\
\cline { 2 - 3 } & D3 & 67.4 \\
\cline { 2 - 3 } & D4 & 73.5 \\
\cline { 2 - 3 } & D5 & 86.3 \\
\hline
\end{tabular}

\begin{tabular}{|l|r|r|}
\hline t-Test: Two-Sample Assuming Equal Variances \\
\hline & Variable 1 & Variable 2 \\
\hline Mean & 51.9 & 74.325 \\
\hline Variance & 17.33125 & 52.9910156 \\
\hline Observations & 5 & 5 \\
\hline Pooled Variance & 35.16113281 & \\
\hline Hypothesized Mean Difference & 0 & \\
\hline df & 8 & \\
\hline$t$ Stat & -5.97958477 & \\
\hline $\mathrm{P}(\mathrm{T}<=t)$ one-tail & 0.000165422 & \\
\hline $\mathrm{t}$ Critical one-tail & 1.859548038 & \\
\hline $\mathrm{P}(\mathrm{T}<=\mathrm{t})$ two-tail & $\mathbf{0 . 0 0 0 3 3 0 8}$ & \\
\hline $\mathrm{t}$ Critical two-tail & 2.306004135 & \\
\hline
\end{tabular}

Notes:

*Initial BPN measurement (no polishing)

**BPN measured after approximately 3 weeks of traffic and averaged between wheel path and center measurements and downhill and uphill measurements in the North bound fast lane 